\title{
SEGREGACIÓN SOCIO-ESPACIAL EN LAS CIUDADES LATINOAMERICANAS
}

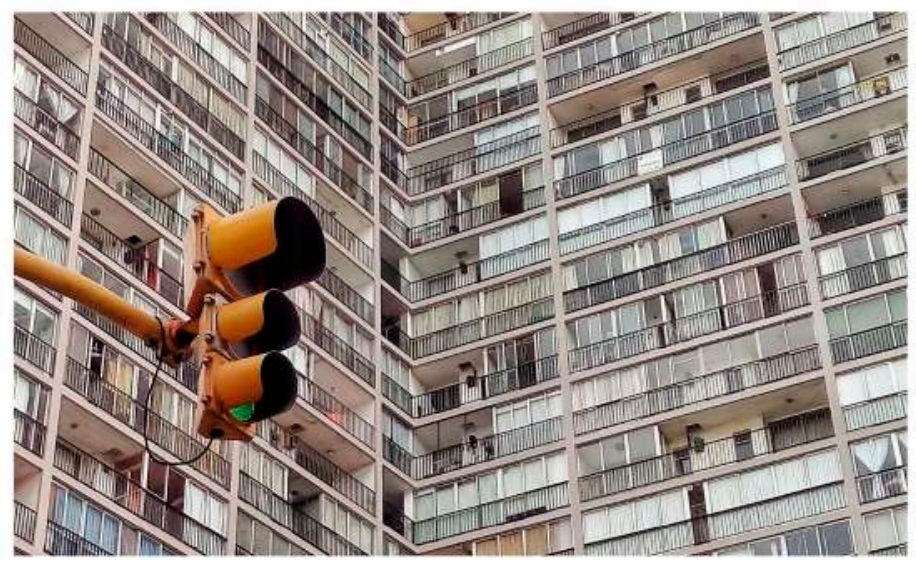

\section{JULIO CALDERÓN COCKBURN SEBASTIÁN AGUIAR ANTÍA (COORDINADORES)}





\section{SEGREGACIÓN SOCIO-ESPACIAL EN LAS CIUDADES LATINOAMERICANAS}





\title{
SEGREGACIÓN SOCIO-ESPACIAL EN LAS CIUDADES LATINOAMERICANAS
}

\author{
Julio Calderón Cockburn \\ Sebastián Aguiar Antía \\ (coordinadores)
}

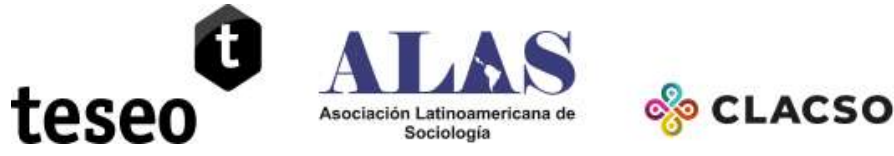


Segregación socio-espacial en las ciudades latinoamericanas /Sebastián Aguiar Antía ... [et al.]; coordinación general de Julio Calderón Cockburn; Sebastián Aguiar Antía.- 1a ed.- Ciudad Autónoma de Buenos Aires: Teseo, 2019. 348 p.; 20 x 13 cm.

ISBN 978-987-723-215-8

1. Movimiento Social. 2. Políticas Públicas. I. Calderón Cockburn, Julio, coord. II. Aguiar Antía, Sebastián, coord.

CDD 304.809

Coordinadora general de la colección: Ana Rivoir

Secretaria general de la colección: Natalia Moreira Cancela

( ) Editorial Teseo, 2019

Buenos Aires, Argentina

Editorial Teseo

Hecho el depósito que previene la ley 11.723

Para sugerencias o comentarios acerca del contenido de esta obra, escríbanos a: info@editorialteseo.com www.editorialteseo.com

ISBN: 9789877232158

Imagen de tapa: Matías Scheinig / @mat.sche, ”Onda verde”, 2019. Las opiniones y los contenidos incluidos en esta publicación son responsabilidad exclusiva del/los autor/es.

TeseoPress Design (www.teseopress.com) 


\section{Presentación de la colección}

La colección de la que forma parte este libro se sustenta en el XXXI Congreso de la Asociación Latinoamericana de Sociología (ALAS), realizado en Montevideo del 3 al 8 de diciembre de 2017. En el marco del Plan de Trabajo para el período 2017-2019, se propuso contribuir a la presencia internacional de la sociología latinoamericana, brindando visibilidad académica a partir de ALAS. Además de dar una amplia difusión a trabajos destacados que fueron presentados en el congreso, se suma el esfuerzo complementario que se realiza en la revista de ALAS: Controversias y Concurrencias Latinoamericanas.

Los libros de la colección siguen la lógica temática de los Grupos de Trabajo. Evidencian la madurez y riqueza de la producción sociológica latinoamericana, fundamentada en su diversidad de enfoques y su espíritu crítico. Cada texto se ubica en los debates de la actualidad social, política y cultural de la región, y así busca analizarla, explicarla y confrontarla. Se trata de una sociología crítica pertinente que se sostiene en la rigurosidad metodológica con base empírica y teórica. De esta forma, los artículos realizan una contribución destacada al desarrollo científico del conocimiento sin perder el compromiso social.

Con el propósito de garantizar la calidad de los trabajos, se convocó a los coordinadores y a las coordinadoras de los Grupos de Trabajo del congreso para que presenten las propuestas a partir de un proceso de selección de las ponencias. También se ocuparon de dar estructura a los libros trabajando en forma directa con las autoras y los autores, y elaboraron la introducción al libro.

Se conformó, por otro lado, el Comité Editorial Académico (CEA), integrado por el Dr. Fernando Calderón, el Prof. Gerónimo de Sierra, la Dra. Nora Garita y el Dr. 
Aberto Riella, y coordinado por quien suscribe en calidad de presidenta de ALAS. El CEA evaluó las publicaciones presentadas, realizó observaciones y sugirió cambios para su aprobación. Además del criterio de calidad y a los efectos de contemplar la mayor diversidad y equidad posibles, se solicitó que cada libro incluyera autores de al menos cinco países del continente y que se cuidara la proporción de artículos de varones y mujeres.

Corresponde, finalmente, agradecer el intenso trabajo tanto del CEA como de las coordinadoras y los coordinadores de los Grupos de Trabajo: sin su dedicación y trabajo académico no podríamos tener este hermoso producto de ALAS. A su vez, queremos destacar el valioso y eficiente trabajo de la Mg. Natalia Moreira, quien ejerció la Secretaría general de la colección.

Por último, agradecemos el apoyo del Consejo Latinoamericano de Ciencias Sociales (CLACSO), que contribuye con la difusión y diseminación de los libros de la colección a partir de sus redes y de la incorporación a su prestigiosa biblioteca virtual.

Esperamos que los objetivos y alcance deseados de la colección se hagan realidad y que su lectura sea de gran utilidad y disfrute para las lectoras y los lectores.

Dra. Ana Rivoir

Presidenta de ALAS

Coordinadora general de la colección 


\section{Índice}

Introducción

Julio Calderón Cockburn

\section{Políticas públicas, mercado inmobiliario y} segregación

Inclusão social e expansão do mercado imobiliário na produção do urbano. Dilemas e contradições do Programa Minha Casa, Minha Vida.

Cristhiane Falchetti

Representaciones y prácticas en territorios urbanos segregados. Una mirada desde los pobladores de barrios de vivienda social en la ciudad de Córdoba (Argentina) ... 53

Ana Laura Elorza

Políticas urbanas y habitacionales en localidades intermedias. El caso del Municipio de Río Grande (Tierra del Fuego, Antártida e Islas del Atlántico Sur), Argentina

Nadia Finck

Brasil e Uruguai: duas experiências de modernização e de habitação de interesse social na América Latina no início do século XXI

Tiago Vieira Rodrigues Dumont

\section{Mercado inmobiliario, segregación y gentrificación}

A reprodução dos padrões de segregação residencial en Salvador (Brasil). Uma análise crítica das intervenções habitacionais do Estado ao exemplo de novos alagados .121 Stephan Treuke 
Reestruturação urbana, novos produtos imobiliários e segregação socioespacial en cidades médias brasileiras.

O caso de Santa Cruz do Sul 145

Rogério Leandro Lima da Silveira

Regreso al centro con fragmentación urbana. Efectos del repoblamiento inmobiliario en el centro histórico del Gran Santiago

Camilo Arriagada Luco

La producción social del hábitat en condiciones de precariedad socio-urbano-habitacional. Un estudio sobre el acceso diferencial al hábitat en un asentamiento irregular del oeste montevideano

Valentín Trinidad Dos Santos

Belo Horizonte, Brasília e Lisboa: observando processos de gentrificação

Rachel de Castro Almeida, Sávio Guimarães y

Patrícia Pereira

\section{Movimientos sociales, participación y políticas de vivienda}

Cidades, movimentos sociais e reforma urbana. Uma análise das ações coletivas em Belo Horizonte no século XXI

Flávia Duque, Ricardo Carneiro, Thaysa Sonale Almeida Silva, Petter Isackson Maia y Rodolfo Pinhón Bechtlufft

A influência das cooperativas habitacionais uruguaias nos movimentos socias pró-Moradia no Brasil.

Aline Marcondes Miglioli

El proceso de renovación urbana en el centro metropolitano de Monterrey. Artistas y activistas: habitar el centro como una forma de resistencia social..295

Rebeca Moreno Zúñiga y Mario Alberto Jurado

Montelongo 
Prácticas e identidades indígenas en contexto de ciudad. El caso de la comunidad indígena Nasa del Cauca, en Bogotá, Colombia ........................................................................... 317 Astrid Lorena Roncancio Alfaro

Acerca de los autores .................................................................... 337 



\title{
Introducción
}

\author{
JuLIO CALDERÓN COCKBURN
}

Este libro reúne una selección de las ponencias presentadas al Grupo 2 "Urbanización del Milenio" del XXXI Congreso de la Asociación Latinoamericana de Sociología (ALAS), realizado en Montevideo, Uruguay, denominado "Las Encrucijadas Abiertas de América Latina. La sociología en tiempos de cambio". De un total de 60 ponencias hemos seleccionado aquellas que tenían un eje en común que emergió como predominante: la segregación socio-espacial. Las ponencias, así como las presentaciones orales (más de 200), como era de esperarse, abordaron un amplio marco de temáticas sobre urbanización y la ciudad, como las políticas de vivienda, las representaciones culturales y la identidad, el transporte y la movilidad, la segregación social, entre otras. El conjunto ofrece una idea de las preocupaciones actuales de las ciencias sociales en torno a los problemas que plantean las ciudades y, a su vez, de los intentos de respuesta desde las políticas públicas.

En este libro hemos seleccionado los temas vinculados a la segregación social y espacial, las políticas de vivienda y los movimientos sociales, por haber sido los más frecuentes. Como quedará claro al lector al revisar los artículos, el tema de la segregación es abordado en su conexión con otras cuestiones vinculadas a las políticas públicas, los nuevos productos inmobiliarios, los mercados de suelo y vivienda, la ciudad informal, los movimientos sociales $\mathrm{y}$ las resistencias.

La segregación social y espacial ha sido un tema clásico de la sociología urbana y el urbanismo y, progresivamente, lo viene siendo de otras disciplinas que acogen la temática. Tradicionalmente se ha estudiado mucho en el norte del 
planeta y menos en América Latina, aunque hay importantes aportes de autores como Caldeira (2007), Cáceres y Sabatini (2004), Dureau et al. (2015), entre otros. La segregación social y espacial es un concepto polisémico (Seguín, 2006: 15), definido a partir de la concentración de un subgrupo de población que comparte una misma característica (raza, etnia, nivel de pobreza, religión, etcétera) o cuando existe una baja mezcla de hogares con condiciones disímiles. Por el contrario, no hay segregación cuando existe mezcla de hogares heterogéneos.

En la literatura existente, los patrones de segregación social y espacial se explican por dos argumentos principales.

En primer lugar, partiendo de la desigualdad de oportunidades económicas y la desigualdad social, la segregación es el producto de la distribución en el espacio del ingreso y de los procesos redistributivos (en forma de salario social) dentro del sistema urbano, y tiene como medio la dinámica de los mercados inmobiliarios (Harvey, 1977). $\mathrm{Si}$, en general, las dinámicas intrínsecas del mercado llevan a la desigualdad, las operatorias de los mercados de suelo y de vivienda, expresados en las rentas del suelo diferenciales, permiten a los grupos sociales, llevados por criterios de distinción o búsqueda o cercanía de redes, agruparse entre sí y separarse de otros grupos. Los factores de mercados se establecen desde las preferencias de hogares y la capacidad de pago.

En segundo lugar, por factores políticos e institucionales, vinculados a la orientación de la inversión pública, la prioridad otorgada a los proyectos inmobiliarios que rentabilizan intereses privados, los patrones de desarrollo urbano formales y el débil, u orientado, planeamiento del uso del suelo. Las reglas que organizan el espacio urbano constituyen patrones de diferenciación social y de separación, incluyendo normas sobre uso del suelo, requisitos de desarrollo y políticas impositivas. Adicionalmente, y en este libro se encontrarán evidencias al respecto, las propias 
políticas de vivienda social en América Latina tienen como efecto la segregación al optar por desarrollos en zonas periféricas de menor valor del suelo. Aspectos sociales y culturales, como el estigma y el prejuicio, suelen acompañar a la segregación.

Esta, según Seguín (2006), es un hecho, un proceso o un efecto. Es un hecho cuando se refiere a zonas relativamente homogéneas pero diferentes de otras. Es un proceso, el cual puede ser independiente de la intencionalidad, y más bien consecuencia de desigualdades de recursos (economía, educación); un resultado colectivo de combinación de comportamientos individuales discriminatorios, que manifiestan la percepción de una diferencia que influencia la elección del lugar de residencia, o una acción organizada de actores y estrategias con el fin de apartar otras categorías sociales (de manera legal o ilegal, a la fuerza o no, directa o no). Finalmente, es un efecto: acceso restringido o desigual a recursos colectivos o públicos urbanos (infraestructuras, equipamientos).

En este libro, el abordaje del tema de la segregación se considera desde las aproximaciones de los mercados inmobiliarios y las políticas públicas, bajo un análisis y propuestas teóricas diversas, así como una variedad de metodologías que combinan análisis de data secundaria y técnicas de recolección cualitativa, incluyendo el recurso a la etnografía y a las entrevistas, estadísticas y fuentes secundarias, estudios de caso en particular, estudios de corte comparativo entre ciudades y países, etcétera.

La presente obra se divide en tres partes.

En primer lugar, "Políticas públicas, mercado inmobiliario y segregación", en el cual se busca comprender el papel de la agencia del Estado en la dinámica urbana, a partir del estudio de diversos programas y proyectos de vivienda en la región. Se inicia con el artículo de Cristhiane Falchetti, de la Universidad de San Pablo, titulado "Inclusão social e expansão do mercado imobiliário na produção do urbano. Dilemas e contradições du Programa 'Minha 
Casa, Minha Vida”, el cual plantea un análisis de la política pública del programa Mi casa, mi vida aplicado en Brasil desde 2009. Plantea, desde la comprensión de la agencia del Estado, que la política se ha orientado a fomentar el desarrollo del sector construcción bajo sus criterios, lo cual ha llevado a viviendas desconectadas del tejido urbano consolidado y segregadas.

A continuación, Laura Escorza, de la Universidad Nacional de Córdoba, Argentina, en el artículo "Representaciones y prácticas en territorios urbanos segregados. Una mirada desde los pobladores de barrios de vivienda social en la ciudad de Córdoba Argentina”, aborda una política parecida, desde el Programa Mi casa, mi vida, a partir de un estudio de caso, el barrio de Los Cuartetos. A partir de entrevistas semiestructuradas, el objetivo se centra en las representaciones y prácticas cotidianas de pobladores beneficiados por la vivienda social. Concluye que los pobladores perciben su vivienda como un espacio aislado, segregado, sin oportunidades y de menor calidad. En suma, al ser reubicados por habitar inicialmente en asentamientos precarios, perdieron ventajas de localización urbana.

El artículo de Nadia Finck "Políticas urbanas y habitacionales en localidades intermedias. El caso del Municipio de Río Grande (Tierra del Fuego, Antártida e Islas del Atlántico Sur), Argentina”, de la Universidad Nacional de Tierra del Fuego, parte de una mirada de la producción social del espacio, considerando autores clásicos (Lefebvre, Bourdieu, Harvey y Soja) y abordando la temática de las políticas de producción de suelo y vivienda por medio de la consideración de una perspectiva histórica, la cual comprende los procesos de informalidad urbana y de exclusión.

Cierra esta primera parte el artículo de Tiago Dumont "Brasil e Uruguai: duas experiências de modernização e de habitação de interesse social na América Latina no início do século XXI", el cual desarrolla un estudio comparativo de las políticas urbanas llevadas a cabo por los gobiernos del Frente Amplio en Uruguay y del Partido de los Trabajadores 
en Brasil. A partir de los impactos de ambas políticas, basadas en Mi casa, mi vida brasileña y del movimiento cooperativo uruguayo, establece dos modelos divergentes, uno de corte urbano industrial y empresarial en Brasil, y otro de autogestión en Uruguay. En este artículo, la discusión sobre el papel del Estado en las políticas neoliberales se plasma a través de la aplicación específica de programas y proyectos de vivienda.

En segundo lugar, la parte "Mercado inmobiliario, segregación y gentrificación” aborda artículos en que la segregación se observa más desde la dinámica de la globalización y los mercados inmobiliarios, aunque sin dejar de lado la acción pública y las propias prácticas de la gente. Se muestra la gradual utilización del concepto de "gentrificación”, entendido como el desplazamiento de sectores trabajadores o populares por clase media y alta de áreas de la ciudad, o por la inserción de usos comerciales y turísticos. La aplicación del concepto, al cual se contrapone el de "mixicidad”, representa un reto teórico a las tradicionales teorías de localización residencial y estructura social, y permite recuperar conceptos de vieja data como "invasión-sucesión" de la Escuela de Chicago y el de filtrado de mercado.

Esta parte se inicia con el artículo de Stephan Treuke, de la Universidad Federal de Bahia, que lleva como título "A reprodução dos padrões de segregação residencial en Salvador (Brasil). Uma análise crítica das intervenções habitacionais do Estado ao exemplo de novos alagados". El trabajo aborda los patrones de segregación en una escala macrourbana, desde su reproducción en el cuadro de la organización socio-espacial, especialmente, desde la actividad de grupos inmobiliarios en alianza con el Estado. Proporciona una visión histórica de las políticas frente a las favelas y concluye con un estudio de caso referido a los "Novos Alagados", surgido en la década de 1970.

El artículo de Roberto Leandro, de la Universidad de Santa Cruz del Sur, "Reestruturação urbana, novos produtos imobiliários e segregação socioespacial en cidades 
médias brasileiras. O caso de Santa Cruz do Sul Brasil”, se ocupa de un caso de ciudad media. El autor presta atención a la dinámica de segregación considerando el mercado de suelo urbano y el mercado inmobiliario en general. Basado en datos secundarios, el artículo se ocupa del desarrollo urbano en la ciudad, abordando aspectos demográficos, los nuevos productos inmobiliarios, como los condominios cerrados, y la diversidad de agentes económicos que los producen.

Camilo Arriagada, de la Universidad de Chile, en el artículo "Regreso al centro con fragmentación urbana. Efectos del repoblamiento inmobiliario en el centro histórico del Gran Santiago", aborda el tema actual del repoblamiento del centro por residencias y centros comerciales. La oferta masiva de proyectos de renovación urbana se vincula a cambios en las economías urbanas, los mercados de vivienda y las preferencias de localización de las clases medias. Esta situación plantea retos a las políticas públicas para una regulación urbana que atenúe sus externalidades negativas y permita gestionar la convivencia y cohesión social entre grupos sociales diversos que comparten un mismo espacio. El estudio debe considerarse una llamada de atención frente a las propuestas de gentrificación, que en Santiago se revela como algo más complejo y no implica el desalojo mayoritario de la clase trabajadora. En esa perspectiva, el autor expone el concepto de fragmentación como uso del suelo en forma de archipiélago.

La contribución de Valentín Trinidad Dos Santos, de la Universidad de la República de Uruguay, "La producción social del hábitat en condiciones de precariedad sociourbano- habitacional. Un estudio sobre el acceso diferencial al hábitat en un asentamiento irregular del oeste montevideano", aborda la segregación social y espacial como correlato de la operatoria de los mercados inmobiliarios en Montevideo, aunque, a diferencia de las otras contribuciones, su análisis de la segregación se enfoca en la diferenciación interna que se produce en los propios barrios precarios, 
un tema poco desarrollado por las ciencias sociales latinoamericanas, para lo cual recurre al clásico trabajo de Elias y Scotson (2016).

Cierra esta segunda parte un artículo de estudio comparativo de Rachel de Castro Almeida, de la Pontificia Universidad Católica de Minas Gerais, titulado "Belo Horizonte, Brasília e Lisboa: observando processos de gentrificação”. El artículo parte del concepto de gentrificación, en especial desde la dinámica que impone la instalación de centros comerciales, antes que de núcleos residenciales. Basado en una metodología etnográfica, aborda las tensiones en los espacios públicos comerciales y los espacios de socialidad urbana, considerando a la gentrificación como parte de las prácticas globales de consumo.

La tercera parte se denomina "Movimientos sociales, participación y políticas de vivienda”, y está compuesta por cuatro artículos.

El artículo de Flavia Duque y otros, "Cidades, movimentos sociais e reforma urbana: uma análise das ações coletivas em Belo Horizonte no século XXI", se detiene en el Estatuto de la Ciudad brasileño, desde la perspectiva del papel de los movimientos sociales en la reforma urbana. Partiendo de la teoría de los movimientos sociales aborda su multiplicidad y diversidad. Se observa su aporte a la nueva Constitución en 1988, y otros mecanismos legales, desde un movimiento que se asentó sobre los pilares del derecho a la vivienda y a la ciudad, la función social de la propiedad y la democratización de la planificación y la gestión urbana. A partir del caso de Belo Horizonte, da cuenta de los movimientos y acciones colectivas urbanas desarrolladas.

A continuación, un estudio comparativo de Aline Marcondes Miglioli, titulado "A influência das cooperativas habitacionais uruguaias nos movimentos sociais prómoradia no Brasil". El estudio, partiendo del déficit y la necesidad de la vivienda, observa cómo el modelo cooperativo uruguayo ha logrado configurar una opción que no depende ni de la iniciativa privada ni de una sobrecarga 
de la intervención estatal, y su influencia en el Brasil. El estudio vincula los movimientos sociales a la política de vivienda, abogando por procesos de autogestión y cooperativistas que permitan a ciertos grupos sociales evitar la exclusión de los mercados inmobiliarios. Una temática vinculada a las propuestas de producción social del hábitat en América Latina.

Desde México, el artículo de Rebeca Moreno y Mario Jurado, "El proceso de renovación urbana en el dentro metropolitano de Monterrey. Artistas y activistas: habitar el centro como una forma de resistencia social", plantea una innovación en el abordaje de la gentrificación al considerar prácticas de resistencia desde los artistas, antes que desde la aproximación clásica de los movimientos sociales. En Monterrey, bajo el liderazgo estatal, la obra pública buscó abrir espacios centrales para la inversión privada en beneficio del turismo pero no de la población residente, lo cual produjo procesos de expulsión. La autora analiza las prácticas de resistencia desde la cotidianidad de la gente.

La contribución de Astrid Roncancio, de la Universidad de San Tomás de Colombia, titulada "Prácticas e identidades indígenas en contexto de ciudad. El caso de la comunidad indígena Nasa del Cauca, en Bogotá, Colombia", aborda un proceso de desplazamiento de población indígena de su lugar de origen a la gran ciudad, relatando la resistencia de la comunidad, su definición de subordinación o dominación y la reivindicación de derechos étnicos desde la apropiación y lenguaje de la ciudad, de acuerdo a las posturas teóricas de Bourdieu sobre los diferentes capitales (sociales, culturales, simbólicos y económicos). 


\section{Bibliografía}

Cáceres, G. y F. Sabatini (2004). Barrios cerrados en Santiago de Chile: entre la exclusión y la integración residencial. Santiago: Lincoln Institute-PUCH.

Caldeira, T. (2007). Ciudad de muros. Barcelona: Gedisa.

Dureau, F., T. Lulle, S. Souchaud y Y. Contreras (2015).

Movilidades y cambio urbano. Bogotá, Santiago y Sao Paulo. Bogotá: Universidad Externado de Colombia.

Elias, N. y J. Scotson (2016). Establecidos y marginales. Una investigación sociológica sobre problemas comunitarios. México: FCE.

Harvey, D. (1979). Urbanismo y desigualdad social. México: Siglo XXI.

Seguín, A. (2006). La segregación socio-espacial urbana: Una mirada sobre Puebla, Puerto España, San José y San Salvador. San José: FLACSO. 



\section{Políticas públicas, mercado inmobiliario y segregación}





\title{
Inclusão social e expansão do mercado imobiliário na produção do urbano
}

\author{
Dilemas e contradições do Programa \\ Minha Casa, Minha Vida
}

\author{
Cristhiane FAlCHETtI
}

\section{Resumo}

Esse trabalho analisa o programa habitacional 'Minha Casa, Minha Vida', com o objetivo de discutir a agência do Estado na configuração urbana, sobretudo no âmbito da moradia. Lançado em 2009, o PMCMV se tornou o maior programa habitacional da história do Brasil, destacando-se pela amplitude do programa e abrangência das camadas sociais até então não contempladas pelos programas de habitação. Mas qual o caráter dessa política e como ela incidiu sobre o urbano? A pesquisa focou no processo de constituição do Programa, na interação entre os agentes, e na distribuição dos empreendimentos urbanos, especialmente na Região Metropolitana de São Paulo (RMSP). Para isso foram utilizados documentos oficiais, dados quantitativos de fontes secundárias, e revisão bibliográfica com pesquisas empíricas. A análise levanta algumas questões para a avaliação do impacto social e urbano do PMCMV, destacando os dilemas e contradições em torno da inclusão social pela via do mercado, como a mercantilização da habitação e o incentivo à financeirização do solo urbano. Como desdobramento, abre-se a discussão em torno da mediação mercadológica na produção e apropriação do urbano. 


\section{Palavras-chave}

Moradia popular; PMCMV; mercadológico.

\section{Introdução}

Conforme já amplamente explorado pela literatura especializada, a expansão urbana no Brasil esteve muito associada ao processo de industrialização, o qual foi particularmente acentuado entre os anos 1950 e 1970, conformando um padrão urbano periférico e segregado. A moradia popular ${ }^{1}$, nesse contexto, se configurou pela informalidade na posse da terra e pela autoconstrução nas regiões periféricas (Holston, 2013; Kowarick, 1983). No caso de São Paulo, esse tipo de urbanização desencadeou uma série de problemas urbanos que vão desde a insegurança da propriedade da moradia até o difícil deslocamento e acesso aos equipamentos públicos, passando pela precária situação de urbanização dos bairros periféricos.

Nos anos 2000, observa-se uma intensa expansão imobiliária, muito fortalecida por medidas institucionais e econômicas do governo, e que se caracterizou pelo mercado formal de moradia e pela articulação do setor imobiliário ao mercado financeiro. Desde 2004 há um acréscimo na produção habitacional na Região Metropolitana de São Paulo (RMSP), cuja evidência pode ser notada no número de lançamentos imobiliários. Contudo, a crise econômica de 2008 ameaçou o mercado imobiliário brasileiro, que vinha numa tendência de distanciamento do Estado.

1 Embora o termo "moradia popular" esteja bastante marcado dentro da política habitacional como uma certa categoria de unidades habitacionais padronizadas, em larga escala e de baixo custo, o uso que fazemos aqui difere dessa visão. Não se refere ao perfil da moradia, e sim ao estrato social da classe trabalhadora de baixa renda, considerando como ele está espacialmente inserido no tecido urbano e quais suas condições de habitação. 
Foi nesse contexto que o governo federal lançou, em 2009, o "Programa Minha Casa, Minha Vida" (PMCMV), o qual visava, inicialmente, construir um milhão de novas unidades habitacionais (UH), destinando $20 \%$ destas à população de baixa renda (de 0 a 3 salários mínimos), por meio da chamada "faixa 1". Ao menos dois aspectos são destaques do PMCMV: a magnitude do programa e a abrangência sobre as camadas sociais até então não contempladas pelos programas de habitação.

A análise apresentada a seguir deriva da pesquisa de doutorado em andamento, que explora a interface entre movimentos de moradia e a dinâmica urbana, explorando a partir do conflito pela produção do espaço urbano. Nesse sentido, compreender a agência do Estado na dinâmica urbana se tornou relevante dentro do escopo da pesquisa, e uma das formas de apreender isso foi por meio de uma análise do PMCMV, buscando compreender o papel do Estado nele e seus impactos na configuração urbana. Para tanto, foi realizada análise documental e de dados de fontes secundárias, especialmente sobre a Região Metropolitana de São Paulo (RMSP), considerando a proposta do programa, os agentes envolvidos, e a distribuição socioespacial dos empreendimentos habitacionais. A partir desse levantamento, procurou-se explorar alguns dilemas e contradições da atuação do Estado na produção do espaço urbano, tendo em vista a "fórmula" de inclusão social pela via do mercado. Com isso, problematiza-se a atuação do Estado frente ao processo de mercantilização do social e as implicâncias da cidadania mediada pelo mercado. 


\section{Entre o crescimento econômico e a inclusão social: o PMCMV como instrumento econômico}

Proposto em 2008, o PMCMV foi lançado no início de 2009 com o objetivo de criar um milhão de novas moradias para diferentes estratos sociais. O processo de definição do programa e sua proposta revelam a tensão existente entre a política habitacional como instrumento de inclusão social, o que inclui moradia digna e o acesso à cidade, e a política habitacional como instrumento econômico direcionada para a expansão do mercado consumidor.

A demanda por moradia e reforma urbana é uma realidade estatística e pauta antiga dos movimentos urbanos, o que influiu sobre o processo de redemocratização e garantiu marcos legais importantes na Constituição Federal de 1988. Nos anos 2000, apesar da tendência histórica contrária, houve avanços institucionais, com a regulação de alguns preceitos constitucionais e a criação de instrumentos de intervenção urbana. São exemplos disso: O Estatuto da Cidade e seus vários instrumentos de regulação e planejamento urbano, o Ministério das Cidades e sua proposta de política urbana, o Conselho das Cidades e as Conferências Nacionais das Cidades, o Plano Nacional de Habitação (PlanHab) e o Fundo Nacional de Habitação de Interesse Social (FNHIS), os Planos Diretores e suas propostas participativas, entre outros.

Todo esse aparato institucional, embora importante do ponto de vista da consolidação de instituições democráticas, teve um peso menor na política habitacional implementada por meio do PMCMV. As disputas em torno das diretrizes e recursos dessa política se fizeram presentes dentro do próprio governo, desde a subdivisão da política habitacional em Subsistema de Habitação de Mercado e Subsistema de Habitação de Interesse Social. Enquanto o primeiro aprofundou os laços entre o mercado imobiliário e o capital financeiro, especialmente via CRI (Certificado 
de Recebível Imobiliário), ${ }^{2}$ e acabou capturando os recursos do FGTS-SBPE - que eram a base de financiamento do SNH (Sistema Nacional de Habitação) e deveriam financiar o Subsistema de Interesse Social -; o segundo, por sua vez, sofreu os reveses da disputa política institucional, sem obter nenhum progresso efetivo até a mudança de orientação da política econômica, em 2006.

A política econômica implementada a partir do segundo governo Lula (2007-2010) esteve fortemente ancorada no consumo interno, que foi incentivado por diversas medidas governamentais, tais como: aumento real do salário mínimo, programas de transferência de renda, facilitação do crédito, subsídios diretos e isenções fiscais. Dois aspectos, no entanto, são particularmente importantes para o assunto aqui abordado: a ampliação do mercado consumidor abrangendo as camadas de menor renda, e o papel das políticas sociais nessa estratégia econômica. O PMCMV pode ser tomado como exemplo paradigmático da combinação entre inclusão social pelo consumo e política social como instrumento econômico de expansão do mercado.

Quando o referido programa foi proposto, o setor imobiliário encontrava-se em apuros diante da ameaça da crise econômica resultante da crise hipotecária nos EUA em 2008. No Brasil, o período anterior, de elevados investimentos, tinha ampliado a produção habitacional e acumulado estoques de terra entre as incorporadoras (Fix, 2011), e a incipiente abertura de capital delas na Bolsa de Valores enfrentava ameaça de retirada de capitais. No ano de 2008 , as incorporadoras pretendiam lançar cerca de $200 \mathrm{mil}$ unidades habitacionais no "segmento econômico" (Rolnik, 2015, p.300), o que tornou o lobby do setor junto ao governo decisivo e neutralizou os fóruns e instituições participativas que haviam sido montadas para a elaboração da Política

2 Na perspectiva de ampliar o mercado imobiliário e abranger as camadas populares, foi necessário aumentar o financiamento, o que incluía os recursos disponíveis no capital financeiro. 
Urbana. Conforme Rolnik (2015, p. 300), toda proposta do PMCMV foi gestada no interior do Ministério da Fazenda, sem a participação das áreas responsáveis pelas políticas sociais e urbanas.

A justificativa do governo ao apresentar o PMCMV deixa clara a motivação econômica que permeia toda a proposta do programa, de modo que a ampliação do consumo de baixa renda e a política de inclusão social se articulam em uma resposta à crise econômica.

A urgência e a relevância da Medida ora proposta se justificam pela necessidade da implementação de ações governamentais estruturadas capazes de arrefecer os impactos da crise mundial na economia brasileira, de forma a promover condições para retomada do processo de crescimento econômico, a geração de empregos e renda e a redução do déficit habitacional, pela ampliação das condições de acesso a moradia às famílias de baixa renda. (Brasil, 2009b - grifos meus)

A principal estratégia econômica do programa foi o fomento à construção civil no setor imobiliário. A Lei n.11.977/2009, que criou o programa, priorizou a produção de unidades habitacionais novas e a readequação, demandando atividade produtiva do setor da construção civil. Associado a isso, o governo Lula estendeu o programa para as camadas sociais de baixa renda (de zero a 3 salários mínimos), oferecendo subsídio de até $90 \%$ do valor do imóvel a este segmento.

Assim, o PMCMV se estruturou em diversas faixas de renda, para as quais variavam o valor e o tipo do imóvel, o valor do subsídio, e as taxas de juros. Em função da pressão exercida pelos movimentos sociais ${ }^{3}$ para que o governo ampliasse o acesso ao programa pelas camadas populares, foram criadas duas outras modalidades:

3 Desde os anos 1990 os movimentos urbanos de moradia vinham se organizando em torno de ocupações em prédios vazios no centro da cidade e terrenos desocupados nas regiões periféricas. 
"MCMV-Entidades" e "PNH-Rural", ambas direcionadas às famílias de baixa renda organizadas por meio de cooperativas habitacionais, associações e demais entidades privadas sem fins lucrativos. Juntas essas modalidades correspondem a 1\% dos recursos do PMCMV. A tabela abaixo apresenta a proposta atualizada, com valores do início de 2016.

Figura 1: faixas do Programa Minha Casa, Minha Vida

\begin{tabular}{|c|c|c|}
\hline Renda familiarmensal* & Faixa doMCMV & Características \\
\hline $\begin{array}{l}\text { Até } \mathrm{R} \$ \\
1.800,00\end{array}$ & faixa 1 & $\begin{array}{l}\text { Até } 90 \% \text { de subsídio } \\
\text { do valor do imóvel. } \\
\text { Pago em até } 120 \\
\text { prestaçõesmensais de } \\
\text { no máximo R } \$ 270,00 \text {, } \\
\text { sem juros }\end{array}$ \\
\hline $\begin{array}{l}\text { Até } \mathrm{R} \$ \\
2.350,00\end{array}$ & faixa $1.5^{* *}$ & $\begin{array}{l}\text { Até } \mathrm{R} \$ 45.000,00 \text { de } \\
\text { subsídio, com } 5 \% \text { de } \\
\text { juros ao ano }\end{array}$ \\
\hline $\begin{array}{l}\text { Até } R \$ \\
3.600,00\end{array}$ & faixa 2 & $\begin{array}{l}\text { Até } \mathrm{R} \$ 27.500,00 \text { de } \\
\text { subsídio, com } 5,5 \% \text { a } \\
7 \% \text { de juros ao ano }\end{array}$ \\
\hline $\begin{array}{l}\text { Até } R \$ \\
6.500,00\end{array}$ & faixa 3 & $8,16 \%$ de juros ao ano \\
\hline \multicolumn{3}{|c|}{$\begin{array}{l}\text { * No caso dos agricultores e trabalhadores rurais, a renda anual da família } \\
\text { deve ser de até } R \$ 78.000,00 \text { por ano** criada em } 2016\end{array}$} \\
\hline
\end{tabular}

Fonte: Governo Federal, PMCMV (Brasil, 2016).

O sistema de financiamento do programa envolve diversas frentes, sendo o Fundo de Arrendamento Residencial (FAR) a principal fonte financiadora dos imóveis na faixa 1 na área urbana. Segundo Relatório do TCU (Brasil, 2013), o FAR correspondeu a $35 \%$ dos investimentos e $53 \%$ das metas de moradia nas fases 1 e 2 . Ele é operacionalizado pela Caixa Econômica Federal (CEF), que contratou 93\% 
dos empreendimentos na fase 1 . No caso da faixa 1, a Caixa adquire os empreendimentos da construtora e financia os imóveis aos compradores.

Figura 2: Fontes de Financiamento do PMCMV

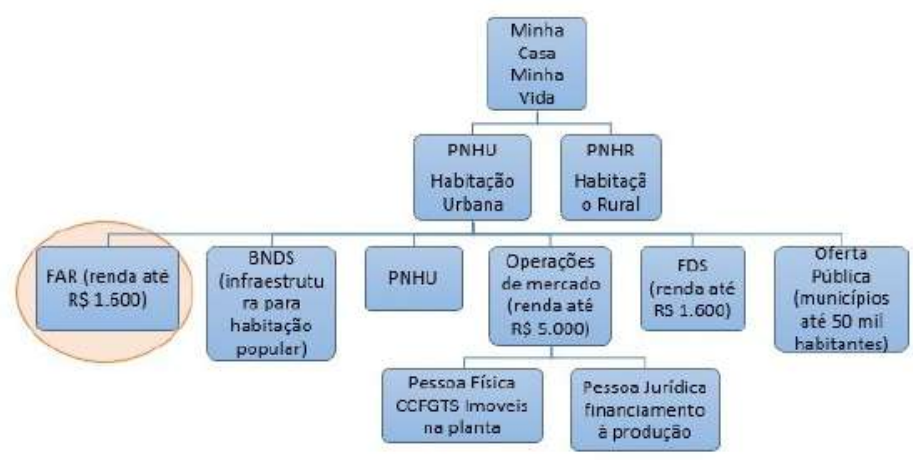

Fonte: TCU (BRASIL, 2013, p.10).

Além dos subsídios que asseguraram a inclusão das camadas sociais de baixa renda, o PMCMV garante taxas de juros abaixo do mercado para todas as demais faixas, por meio de operações de crédito com FGTS (Fundo de Garantia por Tempo de Serviço) e SPBE (Sistema Brasileiro de Poupança e Empréstimo). O Gráfico abaixo ilustra a expansão do crédito imobiliário, especialmente a partir da implementação do PMCMV em 2009. 
Figura 3: Disponibilidade das Modalidades de Crédito

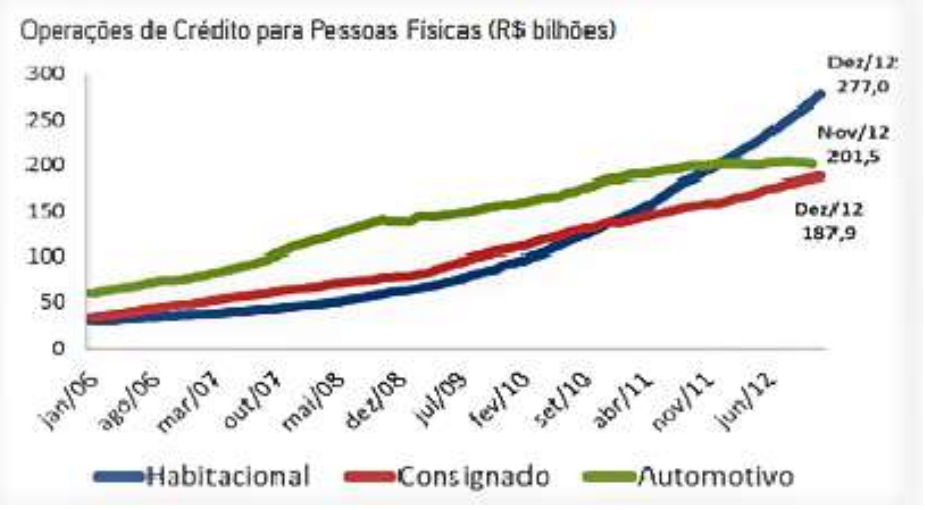

Fonte: SECOVI (2012, p. 14).

No Brasil, o processo de financeirização ${ }^{4}$ do setor imobiliário ainda é uma tendência recente e pouco consolidada. Entretanto, desde 2005, o governo vem promovendo uma série de medidas econômicas ${ }^{5}$ e institucionais $^{6}$ de incentivo ao financiamento imobiliário,

4 "Domínio crescente de atores, mercados, práticas e narrativas financeiros em várias escalas, o que resulta na transformação estrutural de economias, empresas (inclusive instituições financeiras), Estado e grupos familiares" (Aalbers, 2015, p.13).

5 Entre 2004 e 2008, o financiamento para habitação cresceu de 25,7 bilhões para 80 bilhões, sendo que os fundos públicos e os bancos públicos tiveram papel central na provisão do crédito (Rolnik, 2015).

6 Resolução 3.259/05, cria multiplicadores para imóveis novos abaixo de R\$ 150 mil. Resolução 3.280/05, garante a isonomia na concessão de empréstimo para imóveis novos e usados. Resolução 3.304/05, possibilita a redução da taxa de juros por período mínimo de 36 meses. Medidas fiscais de incentivo ao mercado imobiliário; acirramento na competição entre bancos; abertura de Capital da Cyrela. Lei 11.196 ("MP do Bem"), viabiliza o Patrimônio de Afetação e amplia garantias a compradores e financiadores. Financiamento com prestações fixas. Redução de IPI sobre materiais de construção. Inserção da Construção Civil na lei de Micro e pequenas empresas. Crédito na CEF para financiamento das construtoras. 
especialmente para imóveis do chamado "segmento econômico", bem como tem promovido o incentivo à construção civil. Em sua pesquisa, Fix (2011, p.131) mostra como o governo foi criando condições para a operacionalização do capital financeiro no mercado imobiliário, transformando o CRI (Certificado de Recebíveis Imobiliário) em títulos financeiros de valor imobiliário, permitindo a aplicação de fundos de pensão de entidades abertas e fechadas em CRI, a aplicação de até $100 \%$ dos fundos em imóveis no capital financeiro. O conselho do FGTS permitiu a aquisição de CRI, que passou a contar com isenção de imposto de renda para pessoa física.

Ao propor o PMCMV, a comissão interministerial, em sua Exposição de Motivos 33/1999 (BRASIL, 2009b), destaca o problema do crédito e o baixo poder aquisitivo do mercado consumidor como obstáculo ao crescimento econômico e justificativa para que o Estado crie condições de acesso ao crédito às camadas sociais que não atendem aos requisitos do mercado, o que, em outras palavras, implicava que o Estado assumisse o risco do crédito junto aos credores.

3. As atuais restrições de crédito, ainda que por um período curto, podem gerar problemas no setor produtivo com consequências danosas para a economia nacional, sendo oportuna, portanto, a criação de mecanismo que reduza o risco de crédito associado às operações de financiamento habitacional, incentive o retorno dos empréstimos e viabilize a continuidade dos investimentos, principalmente no setor da construção civil, grande gerador emprego e renda às camadas de menor poder aquisitivo.

4. Associado a isso, há o diagnóstico de que o déficit habitacional se concentra no segmento populacional de baixa renda, em razão da dificuldade dessa população em acessar financiamento e outros mecanismos de aquisição de moradia 
que demandem comprovação, regularidade e suficiência de renda, da decadência do SFH nos anos 80 e do fenômeno da urbanização mais acelerada da última década.

10. Com vistas a suprir uma falha do nosso mercado e a facilitar o acesso da população com renda de até 10 salários mínimos a novas linhas de financiamento imobiliário, está sendo proposta a participação da União em um fundo de natureza privada que:

a) garanta o pagamento, aos agentes financeiros, de prestação mensal de financiamento habitacional devida e não paga pelo mutuário final, seja por desemprego, seja por redução temporária da capacidade de pagamento;

b) assuma o saldo devedor do financiamento imobiliário, nos casos de morte e invalidez permanente, e arque com as despesas de recuperação relativas a danos físicos ao imóvel.

Do ponto de vista dos resultados econômicos, o PMCMV teve bom desempenho, atingindo as metas de entregas propostas, alavancando a construção civil e afastando o setor imobiliário da crise. Segundo dados oficiais do Governo Federal (Brasil, 2016), entre 2009 e 2016 foram investidos 294,5 bilhões de reais no programa, contratadas cerca de 4,2 milhões de unidades habitacionais, das quais 2,6 milhões já foram entregues, atendendo a mais de 10 milhões de pessoas.

O impacto na situação financeira das incorporadoras foi imediato após o lançamento do programa, gerando uma inflexão na tendência de queda da Bolsa de Valores e recuperação do setor imobiliário, como se observa nos gráficos abaixo. 
36 - Segregación socio-espacial en las ciudades latinoamericanas

Figura 4: Performance das empresas (PDG, Gafisa, Cyrela, Brookfield) $X$ Índice Fipe-Zap do Rio de Janeiro e São Paulo

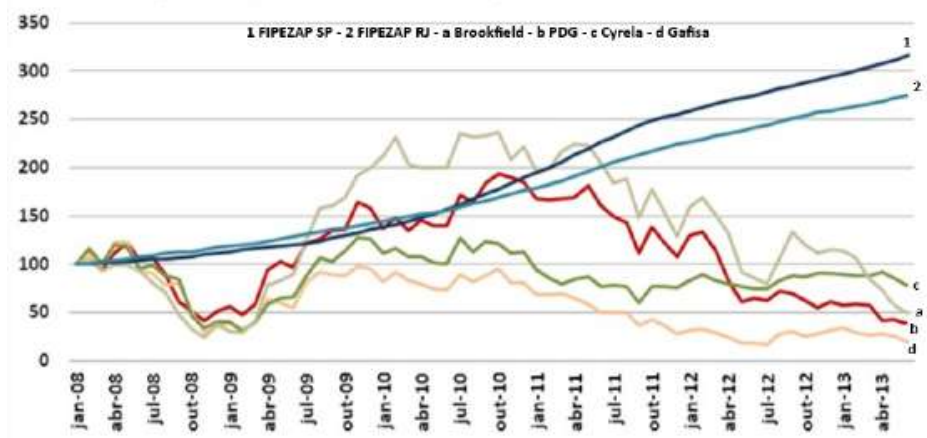

Fonte: adaptado pelo autora, a partir de FIPE-ZAP e Bloonberg.

Figura 5: Variação dos lançamentos residenciais em São Paulo

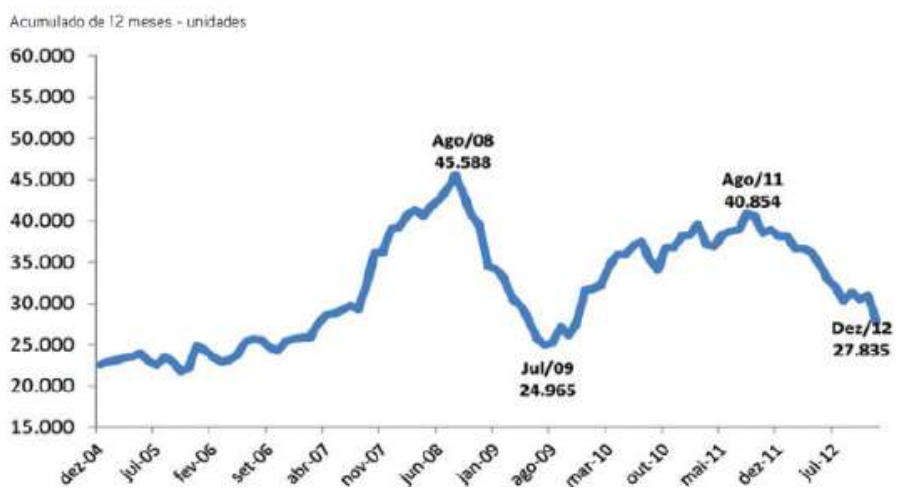

Fonte: SECOVI (2012, p. 22). 
Também é notável a expansão da construção civil, especialmente da área residencial, ${ }^{7}$ apresentando índices de crescimento superior à variação do PIB nacional e tornando-se um setor estratégico para criação de emprego e renda. A indústria da construção civil, que concentra a maior parte dos postos de trabalho no setor imobiliário, registrou recordes de crescimento, com aumento de 15,3\% no nível de emprego formal entre 2009 e 2010 (SINDUSCON, 2010).

Figura 6: Variação do PIB e do emprego formal na construção civil

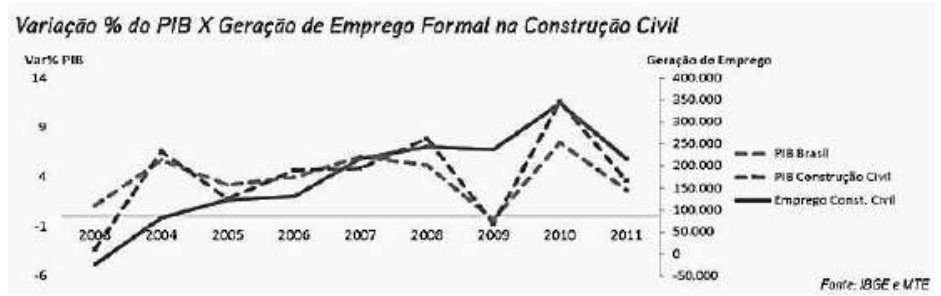

Fonte: SECOVI (2012, p. 13).

Entretanto, apesar da expansão do crédito, dos subsídios e do crescimento da produção habitacional, os preços dos imóveis aumentaram acima do índice geral de preços, especialmente a partir de $2009^{8}$. A inflação imobiliária foi superior a todos os demais índices, inclusive o do custo da construção, prevalecendo o "oportunismo de mercado" entre os agentes do setor imobiliário. Vale destacar ainda que, algumas fontes de financiamento, como o LCI,

7 A construção residencial representou 70\% da área construída entre 2012 e 2015 segundo o ITC (2016). Disponível em: <http://www.itc.etc.br/imagens/relat\%C3\%B3rio_anual_2015_resumido.pdf>. Acesso em 30 mar. 2016.

8 O índice Fipe-Zap apontou uma valorização de $200 \%$ no preço dos imóveis em São Paulo, entre 2008 e 2014, o que reflete sobre os preços dos aluguéis também. 
são isentas de tributação (Imposto de Renda), servindo de incentivos às aplicações e operações financeiras nesse setor. Da mesma forma, as empresas contratadas pelo PMCMV obtiveram redução na tributação sobre o faturamento, de 4\% para 1\% (Brasil, 2004).

Observando os dados do município de São Paulo, uma das regiões mais caras do país, nota-se como o aumento de subsídios e do crédito, que viabilizaram a produção e aquisição dos imóveis, foram acompanhados pelo aumento no preço dos terrenos e dos imóveis, como indica o índice FIPEZAP no gráfico 4.

Conforme houve o crescimento econômico e a renda do trabalho teve aumento real na última década, parte da demanda por casa própria que estava reprimida foi se transformando em demanda efetiva e, com isso, os preços foram subindo acima da inflação desde 2007, levando consigo os ganhos de renda obtidos no aumento dos salários e subsídios à moradia.

Figura 7: Variação anual nos preços dos imóveis em São Paulo - SP

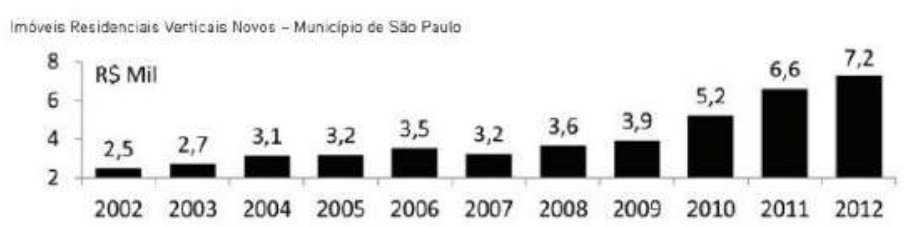

Fonte: SECOVI (2012, p. 26).

Em uma sociedade de profundas desigualdades sociais, como a brasileira, o mercado encontra obstáculos à sua expansão e, para isso, requer a atuação do Estado como garantidor do retorno econômico para que o mercado possa adentrar nas camadas sociais mais baixas. Nesse sentido, as políticas sociais funcionam como instrumentos de 
crescimento econômico e expansão do mercado por meio da inclusão social. É com o apoio do Estado que o mercado se expande entre as diversas camadas sociais, enquanto configura um tipo específico de cidadania, mediada pelo mercado (resta ainda discutir o significado dessa cidadania mediada pelo mercado).

\section{Entre a casa própria e a apropriação da cidade: os impactos do PMCMV na configuração urbana}

Quanto aos impactos sociais e urbanos do programa, a literatura especializada tem destacado a permanência do paradigma periférico e da reprodução homogênea na produção habitacional popular; um aumento da verticalização e reduzidos espaços de convivência coletiva nos empreendimentos da faixa 1; o descolamento local de residência em relação ao tecido urbano, ou seja, pouca conexão entre os empreendimentos e o tecido urbano consolidado (Rolnik, 2015; Rolnik et al., 2015; Fix, 2011; Cardoso, 2012; Shimbo, 2012; Marques e Rodrigues, 2013; Danoso e Queiroga, 2014). Os problemas vão desde falhas na execução dos projetos até a segregação socioespacial, passando pela falta de infraestrutura urbana e homogeneização do espaço.

Ao comparar a situação do déficit habitacional brasileiro com as metas de atendimento do programa, observa-se que o impacto produzido nos diferentes segmentos sociais é desproporcional, visto que cerca de $85 \%$ do déficit habitacional concentra-se no segmento social de até 3 salários mínimos (Brasil, 2008), que compreenderia a faixa 1. A faixa 2 , por outro lado, correspondia a boa parte dos investimentos realizados pelas incorporadoras e que estava em suspenso diante da crise. 
Figura 8: Distribuição das metas do PMCMV em função da faixa de renda das famílias, por fase do programa

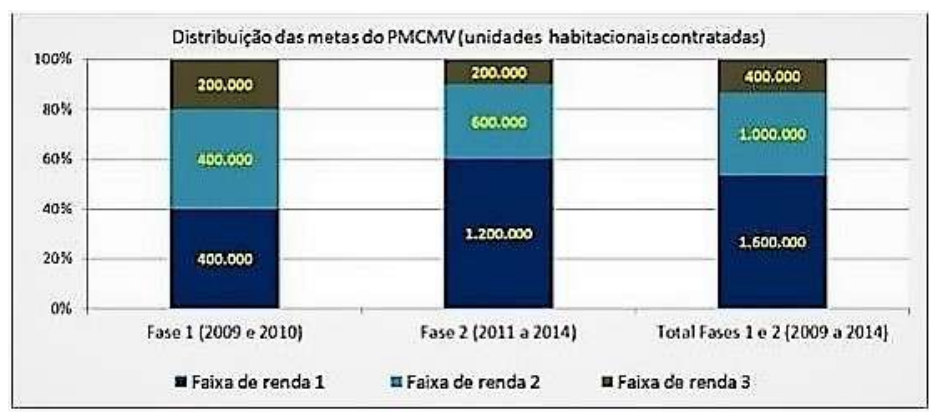

Fonte: TCU (2013, p.17), a partir de dados da CEF e Ministério das Cidades.

Um paralelo com os dados da Região Metropolitana de São Paulo, onde os valores dos imóveis são ainda mais altos e, portanto, mais difíceis de serem enquadrados nos valores estabelecidos pelo PMCMV, mostra que, tanto na fase 1 quanto na fase 2, a desproporção é ainda maior do que a média nacional, pois foram produzidas mais unidades habitacionais para a faixa 2 do que para faixa 1 , a despeito desta concentrar cerca de $83 \%$ do déficit habitacional. Conforme pesquisa de Marques e Rodrigues (2013), comparando-se o déficit habitacional de cada faixa com as entregas realizadas pelo PMCMV até junho de 2013, havia sido atendido apenas $7 \%$ do déficit da faixa $1,50 \%$ da faixa 2 e $100 \%$ na faixa 3.

Além disso, o déficit habitacional na menor faixa de renda flutua mais facilmente, agravando-se em situações de crise econômica. Dados de 2012, da Fundação João Pinheiro ${ }^{9}$, mostram que, mesmo com a construção de novas uni-

9 Cf Relatório (2012): <http://www.fjp.mg.gov.br/index.php/docman/cei/ 559-deficit-habitacional-2011-2012/file>. 
dades habitacionais por meio do PMCMV, o déficit habitacional continuou aumentando na faixa de até três salários mínimos, especialmente nos grandes centros urbanos.

Figura 9: UH produzidas na RMSP nas fases 1 e 2 do PMCMV

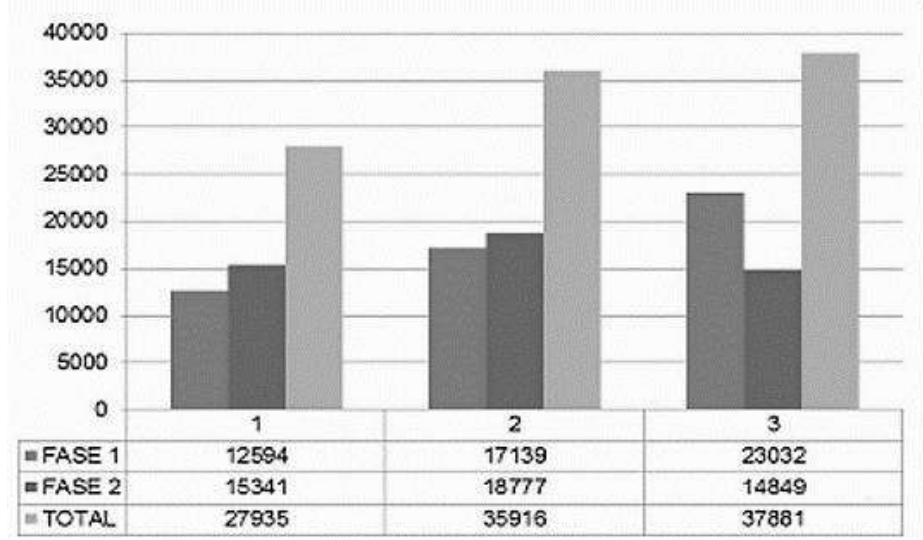

Fonte: Rolnik et al. (2015, p. 141).

Outro aspecto relevante para o impacto social e urbano da política habitacional diz respeito à segregação socioespacial. Historicamente, a expansão urbana em São Paulo esteve associada à industrialização e se intensificou com esta nos anos 1950 e 1970, produzindo um espaço urbano desigual e dividido entre a centralidade principal, onde flui a dinâmica econômica, e um tecido urbano periférico e precário do ponto de vista dos recursos materiais e da qualidade de vida. A política habitacional empreendida desde então influiu sobre esse processo ao construir grandes conjuntos habitacionais em regiões periféricas, onde os terrenos eram maiores e mais baratos, intensificando a ocupação do solo de forma segregada, monofuncional e homogênea. 
Desde a década de 1970, o deslocamento no sentido da periferização envolve a RMSP com seus 39 municípios e vêm crescendo de forma acelerada e desigual, agravando também as condições de moradia ${ }^{10}$. Nos anos 1990, os bairros periféricos da RMSP ganharam moradores ${ }^{11}$, enquanto os bairros centrais da capital perderam população, movimento também acompanhado pela violência e criminalização da periferia e pelos "enclaves sociais". Recentemente, o setor imobiliário vem se expandindo nas regiões periféricas da capital, como mostram os dados apresentados pelo SECOVI (2012) sobre lançamentos imobiliários.

Essa expansão do tecido urbano se caracteriza principalmente por seu caráter residencial e pela formação de novos centros secundários que atendem a população local. As mudanças observadas na configuração urbana apontam para uma maior dinâmica econômica e diversidade funcional, com mais empregos e serviços, como se observa nas regiões como o eixo do ABCD a sudeste, Guarulhos a nordeste e Osasco-Barueri (Rolnik et al., 2015).

Contudo, um olhar mais atento mostra que a configuração desses novos centros está mais associada ao consumo de serviços oferecidos pelo mercado (bancos, agências financeiras, hipermercados, lojas de móveis e construção, lojas de roupas e artigos em geral), o que teria resultado do aumento do consumo entre as classes populares. ${ }^{12}$

10 Entre os anos 1970 e 2000, os moradores em favelas passaram de $1 \%$ para $11 \%$ (Rolnik, 2015, p.277).

$11 \mathrm{O}$ distrito de Anhanguera, na periferia norte de São Paulo, teve a maior taxa de crescimento anual (13,3\%), seguido dos distritos de Cidade Tiradentes $(7,8 \%)$, na zona leste, e Parelheiros $(7,0 \%)$, no extremo da zona sul (Polis, 2009, p.8).

12 Em 2013, o governo federal abriu uma linha de crédito especial para os beneficiários do PMCMV adquirirem móveis e eletrodomésticos nas diversas lojas cadastradas no programa "Minha Casa Melhor". 
Contudo, a região central da cidade continua concentrando a dinâmica econômica, social e cultural em escala metropolitana, dispondo de mais equipamentos e serviços públicos, espaços coletivos de convivência, lazer e cultura. $\mathrm{O}$ fato de a metrópole ser multipolar não anula aspectos específicos da periferia metropolitana como o lugar da classe trabalhadora de baixa renda e acesso precário aos serviços e equipamentos públicos. $\mathrm{Na}$ verdade, o que ocorre é uma complexificação das configurações urbanas, inserindo-se novas problemáticas, como aquela da intensificação da mediação via mercado. A periferia da RMSP é atualmente uma área com oferta de comércio e serviços, porém sem romper com os padrões de desenvolvimento desigual e segregação socioespacial característicos dessa metrópole.

Desse modo, a localização dos imóveis continua a ser um critério relevante para pensar a política habitacional, pois produz diversos efeitos sobre a configuração urbana e a vida das camadas sociais às quais se destina, definindo o seu lugar de inserção no espaço urbano, o que implica aumentar ou diminuir os custos materiais e de bem-estar das pessoas. Além do acesso à infraestrutura pública e aos serviços urbanos que asseguram os direitos de cidadania e a praticidade cotidiana, o acesso à cidade qualifica a experiência social e cultural, proporcionando outras formas de sociabilidade, usos e significados do espaço urbano.

Aproximando o foco na distribuição espacial dos empreendimentos do PMCMV na RMSP, os estudos têm destacado a concentração dos imóveis da faixa 1 nas regiões periféricas de São Paulo, sobretudo no extremo leste e nas áreas mais desvalorizadas da RMSP, enquanto os empreendimentos da faixa 2 e 3 estão mais bem distribuídos e figuram no centro expandido da capital paulista. 
Figura 10: Empreendimentos do PMCMV na RMSP de acordo com as faixas sobre os dados de rendimento médio domiciliar

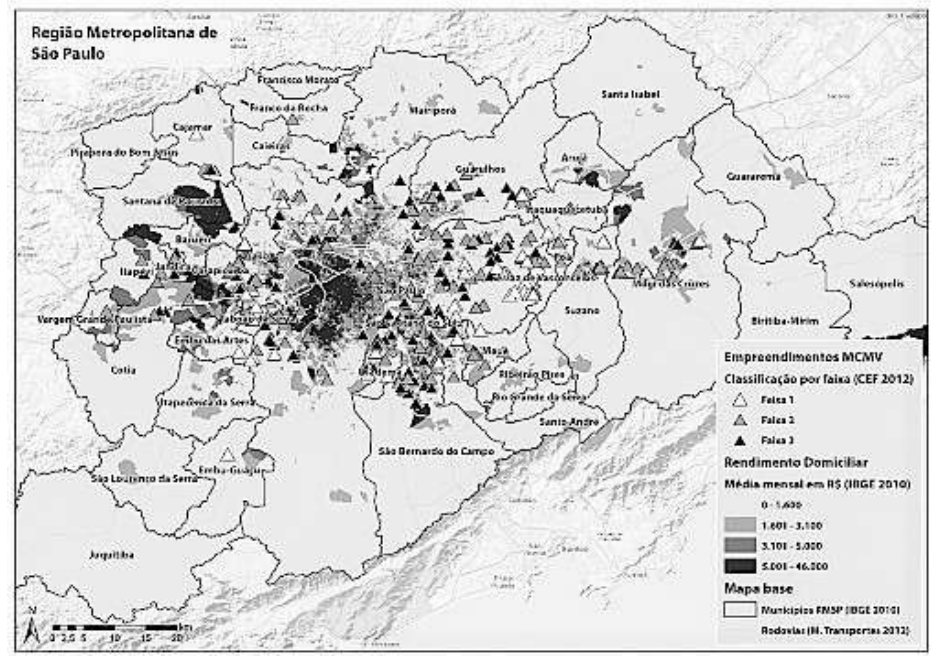

Fonte: Rolnik et al. (2015, p. 143).

Da mesma forma, o entorno dos empreendimentos apresenta baixa diversidade social e dificuldade de acesso aos centros urbanos (Marques e Rodrigues, 2013). Uma pesquisa nacional realizada pelo TCU (Brasil, 2013, p.43) identificou que as maiores carências apontadas por moradores e técnicos do PMCMV são o transporte público e as áreas de lazer e recreação. O gráfico a seguir, ilustra a inserção dos empreendimentos das diferentes faixas do programa em relação ao perfil social do seu entorno. Observa-se que tantos os empreendimentos da faixa 1 quanto das demais faixas têm maior recorrência nos espaços onde predomina os estratos médiobaixos e de trabalhadores manuais, com predomínio da faixa 1 neste último estrato social. 
Figura 11: Distribuição dos empreendimentos em relação ao perfil social do espaço

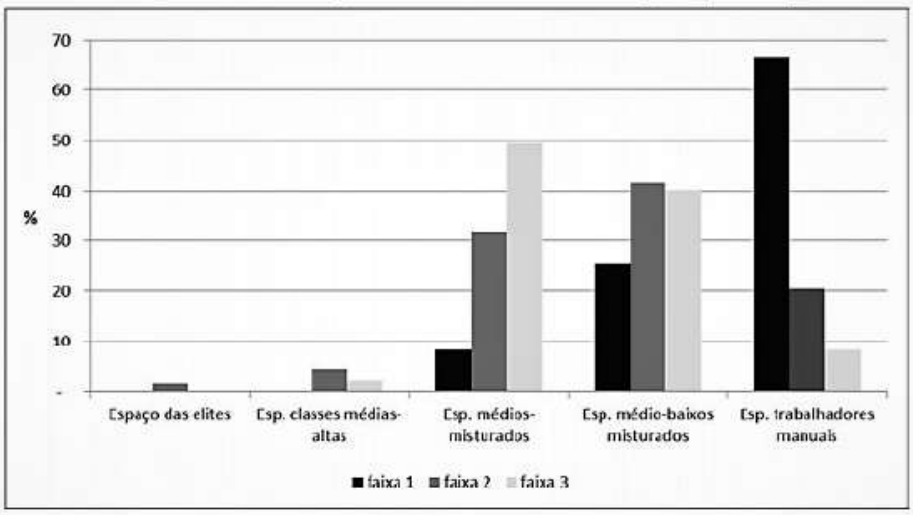

Fonte: Marques e Rodrigues (2013), a partir de dados da Caixa Econômica Federal.

Assim, embora o PMCMV tenha introduzido alguma diversidade social nos espaços de extratos médios e baixos, ele não interfere nos polos da segregação, e os empreendimentos da faixa 1 estão predominantemente alocados no espaço da classe trabalhadora mais pobre. Nesse sentido, o programa repete o padrão periférico e homogeneizador do espaço e a relação entre a produção da habitação popular e seu lugar periférico.

A localização dos empreendimentos de baixa renda é restringida pela valorização imobiliária e pouca disponibilidade de terrenos que atendam aos requisitos dos empreendimentos. A principal via de financiamento desses empreendimentos, o FAR, permite que as construtoras definam o terreno e o projeto e o aprovem junto aos órgãos competentes, sendo as unidades habitacionais vendidas integralmente para a CEF. Não há licitações e as construtoras têm a vantagem de não incorrer em gastos de incorporação imobiliária e comercialização, nem tampouco de correr risco de 
inadimplência dos compradores ou vacância das unidades (Cardoso e Aragão, 2013, p. 37). Com isso, estimulou-se a produção das unidades habitacionais com orientação voltada ao cálculo da rentabilidade econômica, o que impactou no deslocamento das fronteiras periféricas e na padronização das moradias populares, com vistas a reduzir os custos e aumentar os lucros. Mais do que isso, a política habitacional mediada pelo mercado resulta na mercantilização da habitação, em termos lefebvrianos, "valor de troca" se sobrepõe ao "valor de uso" da cidade e o "habitat" impõemse sobre o "habitar". ${ }^{3}$

Isso abre toda uma polêmica em torno do papel do Estado e dos governos locais, não apenas quanto à política de habitação, como também na regulação dos usos do solo urbano. Institucionalmente, caberia um maior protagonismo ao Estado, já que é prerrogativa dos municípios atuar sobre a regulação e uso do solo urbano, entretanto, é sabido que as articulações políticas entre o setor imobiliário, as construtoras e os políticos locais se colocam como um elemento obscuro da pretensa "neutralidade técnica". Ao que consta, os diversos instrumentos institucionais disponíveis para que haja uma melhor regulação sobre o uso do solo urbano $^{14}$ não têm vencido os interesses do mercado imobiliário, e nem o PMCMV está plenamente articulado com essas possibilidades.

13 Para Lefebvre (1999; 2001), "habitar" diz respeito ao "vivido", é uma prática multifuncional, é participar da vida social em sua diversidade e heterogeneidade, apropriando-se coletivamente do espaço e modificando-o; já o "habitat" corresponde ao "concebido" e imposto pela racionalidade estatal e econômica homogeneizante do espaço, reduzindo o vivido ao cotidiano funcional à ordem dominante.

14 Entre as funções que os municípios poderiam ter ampliado estão o mapeamento de áreas públicas desocupadas e em condições de habitabilidade, de modo a dar função social a essas propriedades por meio da viabilização de seu uso no âmbito do programa; a criação de banco de terras destinado ao atendimento das demandas habitacionais de interesse social; e a demarcação de zonas especiais de interesse social, destinadas à construção de moradias para a população de baixa renda e ao provimento de equipamentos públicos de educação, saúde, lazer, entre outros, no entorno dos terrenos disponíveis. 
Na visão de Rolnik (2008), o PMCMV foi concebido sem conexão com qualquer estratégia urbanística ou fundiária, fazendo com que o processo de produção habitacional esteja desvinculado do processo de gestão das cidades, ou seja, há provisão da moradia como um fim em si mesmo. Para Cardoso (2012), o PMCMV não trata devidamente a questão fundiária, o problema da terra e de sua valorização, uma vez que não são acoplados aos investimentos e subsídios do programa instrumentos para controlar a especulação da terra. A situação fica agravada com a falta de compromisso dos governos locais em cumprir com suas reponsabilidades da provisão de equipamentos públicos.

Sem dúvida, os problemas urbanos poderiam ser amenizados, se fossem mobilizados os instrumentos de regulação urbana em favor da política habitacional, mas também falta à política habitacional incorporar uma outra concepção de urbano que leve em consideração a dinâmica e o significado da vida urbana contemporânea para as diferentes classes.

\section{Considerações finais}

Nas duas últimas décadas observam-se algumas mudanças na produção e acesso à moradia popular, envolvendo seus principais agentes. De um lado, acentua-se a articulação entre o mercado imobiliário e o setor financeiro, o que impõe a expansão do mercado consumidor para ajustar-se a exigência de retorno rápido dos investimentos financeiros. De outro lado, o deslocamento do paradigma da autoconstrução para a mercantilização é reforçado pelas políticas de inclusão social via mercado. Nos dois casos o Estado tem um papel central tanto por meio da regularização fundiária, que dificulta as ocupações irregulares e facilita a mercantilização do solo urbano, quanto por meio da instrumentalização e financiamento habitacional, que financeiriza o 
setor imobiliário e impulsiona o mercado consumidor. $\mathrm{O}$ PMCMV implicou a conversão da política social em instrumento de ampliação do mercado, distanciando-se da concepção social pressuposta pelo Estado de bem-estar social. Tal perspectiva implica, não apenas um redirecionamento dos objetivos do social em função da estratégia econômica, como também a promoção do mercado como elemento mediador entre o Estado e os cidadãos.

Os arranjos recentes da política social têm indicado que a mudança central não está na responsabilidade ou na execução das ações voltadas ao social, mas sim na mediação, ou seja, quem intermedia a relação entre a demanda social e o acesso ao bem final. Não é apenas a execução da política social que é contratada no mercado, mas também a sua demanda, definição e orientação, conformando-a à sua lógica de operação. Assim, numa sociedade com profundas desigualdades sociais, que constituem uma barreira à expansão do mercado, este depende da parceria do Estado para que possa acessar as camadas sociais de baixa renda. É nesse sentido que as políticas de inclusão social, transferência de renda e assistência social, em geral, se apresentam como "inclusão pelo consumo".

Não se trata de questionar o acesso ao bem material, mas as implicações da mediação mercadológica sobre a cidadania. É inegável que o PMCMV teve a abrangência social que nenhum outro programa de governo se propôs, entretanto, os vultuosos recursos públicos empreendidos não estiveram comprometidos com a mudança nos padrões históricos da produção do espaço que reforçaram a segregação e a homogeneização urbana. A questão central no caso é em que medida os impactos das políticas sociais refletem ou têm raiz nesse arranjo que combina "inclusão social” com a racionalidade do mercado, ou melhor, que coloca a inclusão social em função do mercado. 


\section{Bibliografia}

Aalbers, Manuel. Corporate financialization. In: Castree et al. (orgs). The Internacional Encyclopedia of Geography: People, the Earth, Environment, and Technology. Oxford: Wiley, 2015. Disponível em: <https://bit.ly/2LzzFII>. Acesso em: 10 fev. 2016.

Brasil. Lei 12.424, de 16 de junho de 2011. Dispõe sobre o Programa Minha Casa, Minha Vida - PMCMV 2 e a regularização fundiária de assentamentos localizados em áreas urbanas. Brasília, 2011.

Brasil. Lei 11.977, de 7 de julho de 2009. Dispõe sobre o Programa Minha Casa, Minha Vida - PMCMV e a regularização fundiária de assentamentos localizados em áreas urbanas. Brasília, 2009a.

Brasil. Exposição de Motivos Interministerial 33/2009/ MF/MJ/MP/MMA/MCidades, de 24 de março de 2009. Encaminha Projeto de Medida Provisória que institui o Programa Minha Casa, Minha Vida - PMCMV. Brasília, 2009b.

Brasil. Lei 10.931, de 02 de agosto de 2004. Dispõe sobre o patrimônio de afetação de incorporações imobiliárias, Letra de Crédito Imobiliário, Cédula de Crédito Imobiliário, Cédula de Crédito Bancário. Brasília, 2004.

Ministério Das Cidades - Secretaria Nacional de Habitação. Déficit habitacional no Brasil 2008. Brasília: Fundação João Pinheiro, Centro de Estatística e Informações, Ministério das Cidades, 2011. Disponível em: <https://bit.ly/2xubgfg>. Acesso em: 20 abr. 2016.

Ministério Das Cidades - Secretaria Nacional de Habitação. Governo Federal. Minha Casa, Minha Vida. Disponível em: <https://bit.ly/25TdIcx>. Acesso em: 17 mai. 2016

Cardoso, Adauto; Aragão, Thêmis Amorim. Do fim do BNH ao Programa Minha Casa Minha Vida: 25 anos da política habitacional no Brasil. In: O programa Minha Casa 
Minha Vida e seus efeitos territoriais. Cardoso, A.L. (org.). Rio de Janeiro: Letra Capital, 2013. Disponível em: <https://bit.ly/2YEdXqk>. Acesso em: 10 jan. 2016.

Cardoso, Adauto. Desafio para a política habitacional: $2^{\text {a }}$ etapa do Programa Minha Casa Minha Vida. Entrevista publicada no site do Observatório das Metrópoles, 2012. Disponível em: <https://bit.ly/2JobaLz>. Acesso em: 16 abr. 2016.

Donoso, Veronica G.; Queiroga, Eugenio, F. Produção Habitacional Social: o programa minha casa minha vida na Região Metropolitana de São Paulo. IX Colóquio Quapá Sel, 25 a 26 ago. 2014. Disponível em: <https://bit.ly/2KVTSc0>.

Kowarick, Lúcio. A espoliação urbana. São Paulo, Paz e Terra, 1981.

Lefebvre, Henri. A Revolução Urbana. Trad. de Sérgio Martins. Belo Horizonte: Editora UFMG, 1999.

Lefebvre, Henri. O Direito à Cidade. Trad. Rubens Eduardo Frias. São Paulo: Centauro, 2001.

FIPE. Índice Fipe Zap de Preços de Imóveis Anunciados: notas metodológicas. São Paulo, set. 2015. Disponível em: <https://bit.ly/2LyZacT>. Acesso em: 04 abr. 2016.

Fix, Mariana. Financeirização e transformações recentes no circuito imobiliário no Brasil. Tese (doutorado em Desenvolvimento Econômico), IE-UNICAMP, Campinas, 2011.

Holston, James. Cidadania Insurgente: disjunções da democracia e da modernidade no Brasil. São Paulo: Companhia das Letras, 2013.

Marques, Eduardo; Rodrigues, Leonardo. O Programa Minha Casa Minha Vida na metrópole paulistana: atendimento habitacional e padrões de segregação. Revista Brasileira de Estudos Urbanos e Regionais, vol. 15, $\mathrm{N}^{\circ}$ 2, pp. 159-177, São Paulo, nov. 2013. Disponível em: <https://bit.ly/2g6YeM1>. Acesso em: 10 jan. 2016 
Ministério das Cidades - Secretaria Nacional de Habitação. Déficit habitacional no Brasil 2008. Brasília: Fundação João Pinheiro, Centro de Estatística e Informações, Ministério das Cidades, 2011. Disponível em: <https://bit.ly/2XqejV0>. Acesso em: 20 abr. 2016.

Rolnik, Raquel. Guerra dos Lugares: a colonização da terra e da moradia na era das finanças. São Paulo: Boitempo, 2015.

Rolnik, Raquel et al. O Programa Minha Casa Minha Vida nas regiões metropolitanas de São Paulo e Campinas: aspectos socioespaciais e segregação. Cadernos Metrópole, vol. 17, $\mathrm{N}^{\circ} 33$, , São Paulo, mai. 2015. Disponível em: <https://bit.ly/32bljEj>. Acesso em: 22 fev. 2016.

SECOVI. Balanço do Mercado Imobiliário (2001-2010): a década da retomada, S/D. Disponível em <https://bit.ly/ 2Jqvw7f>. Acesso em: 02 de jan. 2016.

SECOVI. Balanço Imobiliário (2012). Disponível em: <https://bit.ly/2Xk9wQ3>. Acesso em: 20 fev. 2016.

SINDUSCON. Construção civil cria 193,3 mil novos empregos apenas no primeiro quadrimestre, 16/05/2010. Disponível em: <https://bit.ly/2FMQZpK>. Acesso em: 04 jan.2016.

Tribunal de Contas da União (TCU). Relatório de auditoria: Minha Casa, Minha Vida. Brasília, Secretaria de Métodos Aplicados e Suporte à Auditoria - Seaud, 2013. Disponível em: <https://bit.ly/2YuT69d>. Acesso em: 28 abr. 2016. 



\title{
Representaciones y prácticas en territorios urbanos segregados
}

\author{
Una mirada desde los pobladores de barrios \\ de vivienda social en la ciudad de Córdoba \\ (Argentina)
}

ANA LAURA ELORZA

\section{Resumen}

En la ciudad de Córdoba (Argentina) ${ }^{1}$ durante el período 2003 al 2010 se desarrolló un programa habitacional, "Mi casa, mi vida", de relocalización de la población de villas y asentamientos a nuevos barrios localizados en áreas de la periferia de la ciudad, lo cual ha generado profundos cambios en las prácticas cotidianas de la población y accesibilidad a oportunidades vinculadas a la localización en áreas de centralidad. En este sentido, en el presente artículo abordamos a través de un estudio de caso el análisis e interpretación de las experiencias metropolitanas de los pobladores de este barrio a modo de reconocer las representaciones y prácticas que desarrollan cotidianamente el territorio barrial y la ciudad (la carga simbólica del lugar donde residen, el acceso desigual al espacio urbano, los tiempos y los

1 La ciudad de Córdoba (capital de la provincia de Córdoba) es reconocida como la segunda ciudad con mayor cantidad de habitantes de Argentina, después de la Ciudad Autónoma de Buenos Aires, y registra, según el Censo Nacional de 2010, 1.315.423 personas. 
medios para desplazarse, etc.), como proceso que les posibilita aprehender la posición que ellos y los distintos grupos sociales ocupan en el espacio social y urbano.

\section{Palabras clave}

Segregación; representaciones; vivienda social.

\section{Introducción}

Al igual que la mayoría de las ciudades, la ciudad de Córdoba (Argentina), se ha caracterizado desde sus inicios por la desigual apropiación del espacio según la condición socioeconómica de los grupos sociales. A medida que la ciudad fue extendiéndose, en paralelo al crecimiento poblacional, la configuración de nuevas formas de estratificación social y el valor del suelo urbano, se complejiza el fenómeno de segregación residencial socioeconómico; sin embargo, se ha sostenido la tendencia de que la mayoría de la población de los sectores populares reside en zonas históricamente conformadas con menor oferta urbana, lo que se traduce en menores oportunidades para el desarrollo de actividades (laborales, educativas, culturales, etc.) y de acceso a servicios y equipamientos sociales (Elorza, 2016).

En los últimos años, este proceso de expulsión de los sectores populares hacia la periferia de la ciudad ha sido impulsado desde la política de vivienda social desarrollada por el gobierno de la provincia de Córdoba, con fundamentos de promover un mejoramiento de la calidad de vida de las familias residentes en villas. Sumado a esto, la denominación de estos conjuntos como "barrios-ciudades", la disposición de su ingreso por medio de arcos que significan una ruptura con el tejido urbano, y la localización de equipamientos sociales (centro de salud, escuela, comisaria, etc.) a los que accede la población de estos barrios, constituyen factores problemáticos para reflexionar sobre 
el fenómeno de la segregación socio territorial y sus vinculaciones con los procesos de desigualdad social. En el presente artículo abordamos a través de un estudio de caso (barrio Ciudad de los Cuartetos) el análisis e interpretación de las experiencias metropolitanas de los pobladores de este barrio, a modo de reconocer las representaciones y prácticas que desarrollan cotidianamente el territorio barrial y la ciudad (la carga simbólica del lugar donde residen, el acceso desigual al espacio urbano, etc.), como proceso que les posibilita aprehender la posición que ellos y los distintos grupos sociales ocupan en el espacio social y urbano.

El abordaje metodológico de este trabajo ha sido de tipo cualitativo, realizamos entrevistas semiestructuradas a pobladores del barrio. A través de las entrevistas pudimos ir recuperando distintas formas narrativas que hablen sobre un lugar, lo cual nos acerca a la manera en que el sujeto imagina, representa ese lugar (de Alba, 2009) y desarrolla prácticas en relación a ellas.

\section{Segregación residencial, experiencias y representaciones}

Sabatini (2003) entiende a la segregación residencial como la aglomeración en el espacio de familias de una misma condición social, más allá de cómo se defina las diferencias sociales. Por lo tanto, consiste en una relación espacial: de proximidad territorial o de separación entre personas pertenecientes a un mismo grupo social. Esta localización geográfica se vincula con las modalidades diferenciadas en que estos grupos acceden a la ciudad y a los recursos urbanos, lo que evidencia procesos de desigualdad social que tienen su correlato en lo territorial (Di Virgilio y Perelman, 2014).

La forma en que se produce la segregación es través del mercado inmobiliario, las jerarquías socioespaciales son producidas a través de las formas de producción del espacio 
habitado y por la segmentación de estos mercados (Duhau, 2013). Así, la configuración de los procesos de segregación en las ciudades resulta de las formas pasadas o actuales de la producción del espacio residencial, a través del mercado inmobiliario, el tipo de vivienda y las áreas en las que la misma estará localizada, de acuerdo con el nivel socioeconómico de los hogares (Duhau y Giglia, 2008).

Sin embargo, como proponen Carman, Neiva Viera y Segura (2013) la comprensión de la segregación implica reconocer no solo este proceso de desigual distribución espacial de bienes y servicios, sino también los límites sociales, imaginarios y calificaciones sociales sobre los que se basa este proceso.

Recuperamos a Bourdieu (1999) quien sostiene que el espacio social está inscripto en las estructuras espaciales a la vez que en las estructuras mentales, en los habitus de los agentes, por lo tanto, las grandes oposiciones sociales objetivadas en el espacio físico (para nuestro caso de estudio podemos referir a las oposiciones barrio/villa, centro/ periferia, etc.), tienden a reproducirse en los espíritus y el lenguaje, en la forma de oposiciones constitutivas de un principio de visión y división, es decir, en tanto categorías de percepción y evaluación o de estructuras mentales, en otros términos en las representaciones sociales y en las prácticas que desarrollan los agentes.

En consonancia, Duhau y Giglia (2008) sostienen la hipótesis

... que existe un grado de correspondencia entre cada forma de producción del espacio urbano, su forma de organización, y las prácticas de apropiación y uso de este último, tanto en su dimensión de espacio local, como del metropolitano, usado e imaginado de diferentes formas. (p. 25)

Esto estaría dando cuenta que las experiencias urbanas de los pobladores de villas, de barrios de la periferia y de las áreas centrales, de los countries, son diferentes y desiguales, 
en relación a las posibilidades que les ofrece el espacio urbano como recursos para la reproducción cotidiana y la construcción de sentidos en relación a la ciudad.

En relación al objeto de este trabajo, que nos interesa cómo experimentan y qué prácticas desarrollan cotidianamente el territorio barrial y la ciudad (como proceso que les posibilita aprehender la posición que ellos y los distintos grupos sociales ocupan en el espacio social y urbano), por lo tanto recuperamos la categoría de experiencia metropolitana, que refiere a

... las prácticas y las representaciones que hacen posible significar y vivir la metrópoli por parte de sujetos que residen en diferentes tipos de espacio. El término experiencia alude a las muchas circunstancias de la vida cotidiana en la metrópoli y a las diversas relaciones posibles entre los sujetos y los lugares urbanos, a la variedad de usos y significados del espacio por parte de diferentes habitantes. (Duhau y Giglia, 2008, p. 21)

Este concepto permite una articulación entre las representaciones construidas por los sujetos y las prácticas sociales desarrolladas, ancladas en un territorio dado. A modo analítico podemos identificar dos regiones de la experiencia, donde se desarrollan prácticas y sentidos: el espacio local, entendido como el espacio en los alrededores de la vivienda (barrio, asentamiento, villas) puede caracterizarse por permitir o favorecer una multiplicidad de relaciones sociales, que pueden constituir un tejido relativamente denso y así fortalecer el sentido de pertenencia y el arraigo local; y el espacio metropolitano puede ser escenario de múltiples relaciones, cuya geografía responde a la lógica y a las estrategias de movilidad de los sujetos y a sus relaciones con la metrópoli (Duhau y Giglia, 2008).

Ambas regiones de la experiencia se refieren al "espacio vivido", a partir del cual se articulan los sentidos del espacio con la disponibilidad de acceso y uso de los equipamientos 
funcionales (comercios, transporte, trabajo, servicios, etc.) a partir de los cuales los sujetos deben desplazarse por la ciudad.

\section{Las experiencias metropolitanas de los pobladores de "Ciudad de los cuartetos-29 de Mayo"}

La ciudad de Córdoba se ha caracterizado desde sus inicios por la desigual apropiación del espacio según la condición socioeconómica de los grupos sociales. Desde la década del cincuenta comienzan a configurarse como estrategia de producción de hábitat por parte de familias sin posibilidades de acceder vía el mercado formal de tierra y vivienda, localizadas en áreas centrales e intermedias de la ciudad que implicó mayores oportunidades para el desarrollo de actividades (laborales, educativas, culturales, etc.) y de acceso a servicios y equipamientos sociales (Elorza, 2017).

En el periodo 2003-2010 el gobierno de la provincia de Córdoba ejecuta una política habitacional con objeto de erradicar las villas ${ }^{2}$ en riesgo ambiental. El resultado de esta política ha sido la erradicación de 70 villas a 39 nuevos barrios, en su mayoría localizados en áreas periféricas de la ciudad. Los nuevos conjuntos habitacionales responden a una misma tipología organizativa del territorio, con un "arco de entrada" al barrio, manzanas con viviendas uniformes (de $42 \mathrm{~m} 2$ ) y equipamiento social (escuelas, centro de salud, posta policial) idénticos para todos los casos y fueron denominados como "barrios-ciudades". El barrio "Ciudad de los cuartetos"3 es uno de los nuevos territorios

2 Hacemos referencia a asentamientos informales que se comenzaron a producir en Argentina a partir de la década de 1940 debido a los procesos migratorios del campo a la ciudad en el marco de la política económica de industrialización por la sustitución de importaciones; término análogo a favelas en Brasil, campamentos en Chile o colonias en México.

3 Según datos del último censo poblacional, del año 2010, en este barrio residían 2.204 habitantes. 
construidos por esta política pública de vivienda social. Se encuentra localizado en la zona noreste de la ciudad, en un sector en el que las urbanizaciones residenciales están desarticuladas dentro de un contexto rural-industrial (Imagen 1 ), sin barrios colindantes.

En noviembre del año 2004 este barrio fue inaugurado, conformado por 418 viviendas y el equipamiento comunitario (escuelas, centro de salud, comisaria, comedor de ancianos, centro de cuidado infantil y espacios verdes). Al igual que el resto de los conjuntos habitacionales producidos por este programa, la entrada al barrio está demarcada por un arco en el que se expone su nombre (Imagen 2), lo cual representa una ruptura con el entorno, remarcando el ingreso al mismo.

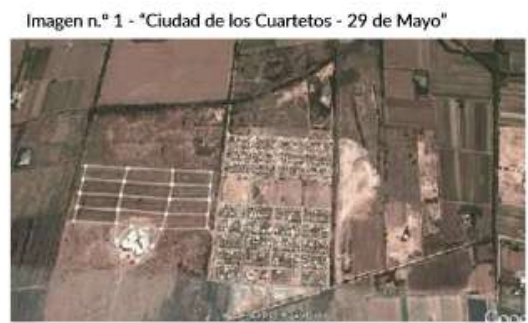

Fuente: Google Earth.
Imagen n. 22 - Arco de entrada al barrio

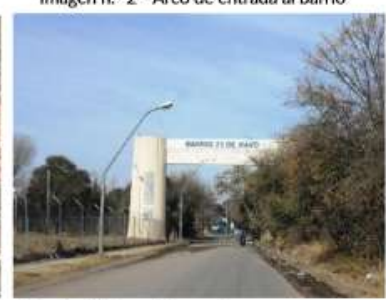

Fuente: Elaboración propia.

En este sentido, podemos caracterizarlo como un espacio segregado, configurado a través de un proceso de "segregación acallada", el cual alude a una producción directa, aunque implícita, de situaciones de confinamiento; es decir, se presenta como una medida asistencial o una política de inclusión, cuyo efecto es la exclusión o el desplazamiento de sectores populares (Carman, Neiva Viera y Segura, 2013) hacia las áreas periféricas, de menor valor de suelo y calidad urbana de la ciudad. 
Hace más de diez años que los pobladores de este barrio habitan este territorio, lo cual ha significado un proceso adaptación, prácticas y apropiación del espacio, nuevas configuraciones de experiencias metropolitanas en vinculación a la vida relación con la ciudad y en el barrio.

\section{Experiencias en vinculación con el espacio metropolitano}

Como desarrollamos en trabajos anteriores (Elorza, 2016; 2017) en el caso de estudio, la localización del barrio en la periferia es percibida por sus residentes como un espacio aislado, sin oportunidades. Los vecinos perciben claramente la desigual provisión, calidad y acceso a oportunidades en distintas áreas de la ciudad, cuestiones centrales en las practicas tendientes a la reproducción social cotidiana de las familias. Sin embargo, no solo la localización periférica del barrio es entendida como aislamiento, sino que es reforzado por su denominación de "barrio-ciudad" y la arquitectura del mismo, el cual irrumpe en una trama discontinua $\mathrm{y} \sin$ barrios vecinos.

En los relatos obtenidos durante las entrevistas aparece la representación de la división entre el barrio y la ciudad, expresados en términos opuestos de adentro y afuera (Segura, 2006), como expresa una vecina, "... cualquier circunstancia te obliga a salir del barrio a buscar algún tipo de cosa, que es lo que no hay en el barrio, para la escuela hay que ir afuera, para la salud hay que ir afuera...", o un adolescente "mejor hubiera sido que nos dejaran en el Liceo [por una de las villas de la cual provienen], porque estamos tirados acá adentro, no tenés salida para ningún lado...".

Esta oposición entre adentro-afuera denota la percepción de las múltiples fronteras que configuran el territorio: geográfica (estar en la periferia), material-arquitectónico (el arco de ingreso al barrio), simbólica (la denominación 
del barrio-ciudad) y social. Estas fronteras modelan la vida social de estas familias, que se estructura y depende, en gran medida, de la movilización de (escasos) recursos y la elaboración de variadas estrategias para atravesar la frontera con la finalidad de acceder a bienes y servicios escasos o ausentes en el barrio necesarios para la reproducción de las condiciones de vida (Segura, 2006).

En el análisis de la segregación socio territorial, no debemos suponer que los grupos sociales de menos ingresos únicamente se encuentran fijos en sus espacios de residencia. Como platea Segura (2012) los barrios en donde habitan los sectores populares no son espacios autosuficientes; por lo tanto, es central analizar las prácticas de movilidad para leer desigualdad social y urbana. Si bien los vecinos de este barrio residen en una de las áreas específicas de la ciudad homogéneamente pobre, y desde una perspectiva espacial, encontramos al barrio aislado del entorno urbano con ciertas barreras para la movilidad, no es un ámbito relativamente autosuficiente y sus habitantes no permanecen "encerrados" allí, sino que deben invertir mayores recursos económicos y de tiempo para movilizarse hacia la obtención de bienes, recursos y servicios.

Hannerz (1986) ha identificado distintos dominios urbanos que implican movilidad por parte de las personas en la ciudad, estos son: doméstico, aprovisionamiento, recreación, vecindad y tránsito (citado por Segura, 2012); en el caso analizado prevalece el aprovisionamiento como justificativo a las salidas del barrio, encontrando diferencias en estas prácticas en relación al género y a la edad. Los hombres, por lo general, salen a trabajar hacia otros espacios de la ciudad, en su mayoría en sectores de la ciudad con mayor mixtura social; y las mujeres son las encargadas de la educación, salud y el abastecimiento de bienes (alimentos, vestimenta, medicamentos, etc.).

Más allá que el barrio cuenta con un centro de salud y escuela primaria y secundaria, debido a la "mala calidad" o a la no prestación de esos servicios, las mujeres desarrollan 
distintas estrategias en busca de garantizar una buena atención medica y una educación de calidad para sus hijos, que la brindan "fuera" del barrio; como nos comenta una vecina sobre los niños que asisten a escuelas de otros barrios "... y está bien para que los chicos salgan de este mundo, que no crean que es esto nomás..." (Marta).

$\mathrm{Si}$ bien muchas de las prácticas de desplazamiento son instrumentales (ir a hacer compras, hacer trámites, ir al médico, etc.), en otros casos representan estrategias de inversión en el capital cultural y social de los hijos, en busca contrarrestar los efectos del aislamiento, que implica "quedarse" en el barrio.

\section{Experiencias en el barrio: vivir en un "barrio ciudad"}

Como mencionamos anteriormente, es espacio local es el espacio en los alrededores de la vivienda, en este caso, el barrio que puede caracterizarse por promover una multiplicidad de relaciones sociales, que pueden constituir un tejido relativamente denso y permitir construir un sentido de pertenencia y apropiación.

El barrio analizado ha sido construido a partir de una política habitacional, y al ser localizado en un área de la ciudad desarticulada del entorno urbano, además de las viviendas también se instaló el equipamiento necesario para el desenvolvimiento cotidiano de las familias en su reproducción social. En este sentido, el barrio cuenta con instituciones públicas como: centro de salud, guardería, escuela primaria y secundaria, comedor de ancianos y posta policial.

Podemos diferenciar las valoraciones y prácticas que desarrollan los vecinos sobre el acceso y calidad de los servicios de consumo colectivo, en este caso profundizamos sobre los servicios sociales de bienestar, dirigidos a establecer el nivel social mínimo de bienestar de la población (en términos de salud, educación, vivienda, etc.) (Jelin, 
1984); en el que territorio barrial se constituye en un factor importante en las posibilidades de acceso de oportunidades y recursos.

En relación a la calidad de los servicios sociales de bienestar de educación, es valorada de manera diferente por los vecinos, en algunos casos es considerada buena y en otros, deficiente; dado que las mujeres identifican bajos logros educativos de los niños que asisten a la escuela del barrio: no saben leer, tienen dificultades para sumar y restar, hay muchos problemas de disciplina, entre otros. En los comentarios de los entrevistados se aprecia una valoración resignada sobre las oportunidades que tienen los niños que asisten a la escuela del barrio, “... y bueno y están los chicos que se tienen que morir acá, digo morir acá porque los padres no tienen recursos para mandarlos a otros colegios..." (Marta), entendiendo al barrio como un lugar de abandono y relegación, como plantea Bourdieu (1999).

Como mencionamos anteriormente, una de las estrategias desarrolladas por algunas familias, en busca de garantizar una educación de calidad y de inversión en el capital social, es la de enviar a sus hijos a instituciones educativas públicas o privadas localizadas en otros barrios. ${ }^{4}$

Similar es la valoración que realizan sobre el servicio de salud brindado en el centro de atención primaria del barrio, si bien las limitaciones a las que refieren los entrevistados se podrían analizar en el marco de las políticas sociales de salud, ellos identifican estas deficiencias en el equipamiento sanitario y la atención medica, como lo apreciamos en las expresiones de las vecinas; “...acá es para primeros auxilios, es muy precario, muy precario, si te duele la garganta, si te duele el oído no porque no tienen el aparatito para verte...” (Graciela); “...el viernes mi hija

4 Esta estrategia ha tenido como resultado una disminución de la matricula de niños que asisten a la Escuela Provincial Primaria Dr. Tagle, ubicada en el interior del barrio, según lo informado en una entrevista por la directora de dicha institución Alejandra Bueno. 
llevó a la nena porque estaba con mucho vomito y el doctor no la quiso atender, nos tuvimos que ir al dispensario de otro barrio y nos atendieron en la guardia de diez, pero nosotros no pertenecemos allí, no tendríamos que haber ido, supuestamente acá también deben atender 24 horas pero no..." (Mariana).

Sumado a la mala prestación del servicio sanitario de atención primaria, se encuentran las dificultades ante emergencias, debido a que las ambulancias tampoco "entran" al barrio también por ser considerado una zona peligrosa, como dice Mariana "estamos en el lejano oeste, si llamas a una ambulancia no te entra porque dicen que es zona roja", por lo que ante situaciones de emergencia deben apelar a la solidaridad de algún vecino con automóvil.

Otra dimensión de análisis en relación a las experiencias en el torno barrial es la construcción de ciertos sentidos de sociabilidad entre los vecinos, que permitirían construir sentidos y prácticas sobre la apropiación del territorio. En este sentido, cuando los mismos vecinos dan sus opiniones respecto a su propio territorio, son notables las fronteras que vuelven a remarcar entre "ellos" y los "otros". Esta división responde no solo a una frontera geográfica, sino también simbólica, ligada a la identidad construida en las antiguas villas y a la conformación del nuevo barrio, que contribuye a la construcción de calificaciones negativas en su interior.

$\mathrm{Al}$ inicio del trabajo de campo, nos encontramos que las expresiones de los entrevistados daban cuenta de la coexistencia de dos barrios, uno 29 de Mayo y el otro, Ciudad de los Cuartetos; como nos remarcó Gustavo “...acá es 29 de Mayo y allá Ciudad de los Cuartetos, nada que ver con nosotros...".

Ante nuestra imposibilidad de distinguirlos, le pedimos que nos señalaran la localización de cada uno de ellos. En su explicación, nos señalaban que 29 de Mayo es la parte de "adelante", es decir, desde el arco de entrada hasta el espacio verde (en el que se encuentran las estatuas de los 
músicos de cuarteto), donde se relocalizaron las primeras familias, que provenían de la villa el Chateau y la Salada. Unos meses más tarde, fueron

trasladadas familias de la villa Parque Liceo 3. Sección, en el sector de "atrás", con el que se finaliza el proyecto habitacional y se designa el nombre de Ciudad de los Cuartetos al barrio.

Sobre la conformación poblacional del barrio, Marta nos explica cuáles eran sus temores:

...era como una bolsa de gatos, porque traían un poco de una villa, otro poco de otra, pero nosotros del Chateau siempre nos mantuvimos muy unidos, allá la droga los chicos no la conocían, nunca nada, no pasaba nada, solo una vez un señor se quiso abusar de una hijita, eso fue lo peor que pasó en la villa, era una villa muy tranqui, con gente muy trabajadora, y después vinimos acá con treinta familias de Villa Urquiza, con cien de allá [refiriéndose a Parque Liceo 3. ${ }^{a}$ Sección], no sabés lo que fue la pelea entre vecinos, no sabés, era tristísimo...

A - ¿Por qué motivos eran las peleas?

$\mathrm{M}-\mathrm{Y}$ porque algunos se drogaban o estaban borrachos, cosas que nosotros allá no vivíamos...

En estas expresiones se evidencia el doble proceso en la construcción de estas representaciones sociales de identificación y diferenciación, por un lado, la revalorización de los atributos de su grupo y por otro lado, cómo se trasladan los estigmas territoriales a los "otros" habitantes del barrio, depositarios de todas las cualidades negativas, en este caso identificándolos como drogadictos, borrachos, y delincuentes; sin mediar en el análisis las transformaciones y la incidencia de las redes de crimen organizado o circuitos económicos ilegales (narcotráfico, robos, etc.) que han tenido en los territorios populares un proceso creciente de marginalización producido por los procesos de segregación territorial en los últimos quince años. 
Se reproduce a menor escala la delimitación de "zonas prohibidas”, lo cual repercute en sus respectivas prácticas, de evitamiento o de conflicto que en muchos casos derivan en situaciones de violencia, que hace más difícil la convivencia en un barrio aislado; como expresa Jesica:

...los de allá nos dicen "los de arriba" y los de acá le dicen "los de abajo" [...] hemos tenido que soportar, hasta los dos años más o menos, que la gente se empezó a conocer, bastante cosas feas, hasta muertes, lo que pasa es que se calman los grandes pero le queda en resentimiento a los medianos, a los chicos, así, los de acá no pueden ir para allá, los de allá no pueden venir para acá, si yo tengo problema con una mujer de allá me van a mandar a las hermanas, a las cuñadas, es así por edad, es feo...

Estas "zonas prohibidas" al interior del barrio delimitan los sectores en que los vecinos no pueden circular, lo cual tiene implicancias centrales en el fenómeno de la segregación, ya que "la presencia y encuentros se reducen, la interacción disminuye, el desconocimiento mutuo crece, y los prejuicios y estigmas se constituyen en el principal mecanismo de aproximación al otro" (Saravi, 2008: 107).

Esto también ha tenido como resultado la imposibilidad de generar estrategias de acción colectiva, como plantea Graciela"no se puede hacer un centro vecinal porque empiezan que no vos sos de tal parte, vos de la otra parte del barrio, y empiezan que sos de allá abajo, no de allá arriba y así y no se hace nada, el barrio está dividido...”.

Las diferencias construidas repercuten en situaciones de desconfianza e imposibilita la conformación de nuevas redes sociales, siendo la sensación de inseguridad y replegamiento al espacio privado, el "adentro" de la casa, algunas de sus manifestaciones; esto tal vez se deba a que ya no es necesaria la acción colectiva en busca de resolver problemáticas ligadas al hábitat como en el antiguo territorio de las villas (cortes de luz, provisión de agua, etc.). 


\section{Reflexiones finales}

En este trabajo intentamos aportar a la comprensión de los procesos de segregación socio territorial, entendiéndola no solo desde su manifestación geográfica, sino también desde los sentidos, fronteras y representaciones que se construyen socialmente como mecanismo de fundamento y sustento de las desigualdades sociales y territoriales. En especial, nos interesa dar cuenta del rol del Estado en los procesos de segregación acallada (Carman, Neiva y Segura, 2013) en los que se produce una expulsión de los sectores populares hacia la periferia de la ciudad, enmascarada de política asistencial.

El barrio "Ciudad de los Cuartetos-29 de Mayo", producido por una política de vivienda social a través de la cual el Estado ha construido territorios homogéneos con una arquitectura diferenciada (por tipología, colores de las viviendas, espacios públicos y arcos de entrada al barrio con la denominación de "barrios-ciudades") dirigida a los pobladores de las villas se constituye, como hemos analizado, en marcas simbólicas que reproducen y profundizan la diferenciación social entre los grupos sociales.

En este sentido, el análisis de las experiencias metropolitanas de los pobladores de este barrio permite articular las dos regiones de desenvolvimiento cotidiano, la barrial y la metropolitana, a partir de las cuales de manera interrelacionada se construyen modalidades, usos y significados de los lugares y las desiguales maneras de apropiación y disfrute de los recursos urbanos materiales y simbólicos de la ciudad. Los relatos de los entrevistados recuperados a lo largo de la ponencia dan cuenta de los numerosos problemas que deben sobrepasar para realizar las prácticas tendientes a la reproducción social cotidiana de las familias (localización, acceso a servicios, conflictos intrabarriales, etc.). En comparación con sus antiguos lugares de residencia (las villas y su entorno), les resulta más difícil desarrollar las estrategias 
de sobrevivencia en este territorio, convirtiéndose en un factor central de reproducción de las condiciones de pobreza y desigualdad.

Estos avances en la comprensión del fenómeno estudiado representan también nuevas líneas de abordaje que debemos seguir profundizando, en especial, el estudio relativo a cómo los sentidos y representaciones que los pobladores producen sobre sus territorios pueden significar disputas en la producción de los estigmas y significados que se van construyendo en relación a los lugares y los sujetos de la ciudad (Elorza, 2017); y como aporte para el diseño de las políticas sociales habitacionales que incorporen las dimensiones simbólicas de la producción territorial.

\section{Bibliografía}

Bourdieu, Pierre (1999). La Miseria del Mundo. Buenos Aires: Fondo de Cultura Económica.

Carman, Neiva y Segura (2013). Introducción. Antropología, diferencia y segregación urbana. En Carman, Neiva y Segura (coords.), Segregación y diferencia en la ciudad. Quito: FLACSO, Sede Ecuador: Consejo Latinoamericano de Ciencias Sociales (CLACSO): Ministerio de Desarrollo Urbano y Vivienda.

De Alba, M. (2009). Representaciones sociales y el estudio del territorio: aportaciones desde el campo de la psicología social. Recuperado el 10 de enero de 2013, de https://bit.ly/2i0FsGD.

Di Virgilio, M. M.; Perelman, M. (2014). Ciudades Latinoamericanas. La producción social de las desigualdades urbanas. En: Di Virgilio, M. M.; Perelman, M. Ciudades latinoamericanas: desigualdad, segregación y tolerancia, pp. 8-19. Buenos Aires: CLACSO. 
Duhau, Emilio (2013). La división social del espacio metropolitano. Una propuesta de análisis [en línea]. Nueva Sociedad, 243, pp. 79-91, enero-febrero 2013 [10 de octubre 2014]. Disponible en: https://bit.ly/2MrgW46. Duhau, E. y Giglia, A. (2008). Las reglas del desorden: habitar la metrópoli. México: Siglo XXI Editores, Universidad Autónoma Metropolitana.

Elorza, Ana Laura (2017). Segregación residencial y estigmatización territorial: representaciones y prácticas de los habitantes de territorios segregados. Ponencia presentada en Conferencia Internacional Marginalidad urbana y efectos institucionales. Santiago de Chile, 11, 12 y 13 de octubre de 2017. Universidad Pontificia de Chile.

-- (2016). Segregación residencial socioeconómica y la política pública de vivienda social. El caso de la ciudad de Córdoba (Argentina). Revista Cuaderno urbano, N.o 20 , pp. 71-94.

Jelin, Elizabeth (1984). Familia y Unidad Doméstica: mundo público y vida privada. Buenos Aires: CEDES.

Sabatini, F. (2003). La segregación social del espacio en las ciudades de América Latina. Recuperado el 11 de enero de 2008, de https://bit.ly/2JUNnFL.

Saravi, G. (2008). Mundos aislados: segregación urbana y desigualdad en la ciudad de Mexico. Eure, XXXIV (103), pp. 93-110.

Segura, R. (2006). Segregación residencial, fronteras urbanas y movilidad territorial. Un acercamiento etnográfico. Cuadernos del IDES, 9.

-- (2012). Elementos para una crítica de la noción de segregación residencial socio-económica: desigualdades, desplazamientos e interacciones en la periferia de La Plata. Revista Quid 16, 2, pp. 106-132. 



\title{
Políticas urbanas y habitacionales en localidades intermedias
}

\author{
El caso del Municipio de Río Grande \\ (Tierra del Fuego, Antártida \\ e Islas del Atlántico Sur), Argentina
}

\author{
NADIA FINCK
}

\section{Resumen}

El presente trabajo propone dar cuenta de una revisión crítica de las políticas de producción de suelo y vivienda por parte del municipio de Río Grande en el período 2005-2015. Río Grande, es una ciudad intermedia que se encuentra ubicada en la Provincia de Tierra del Fuego, en la Patagonia Austral argentina. Las características que ha adquirido la expansión urbana en esta localidad en los últimos años indican -de acuerdo a los datos del Atlas IDque los tejidos residenciales de asentamientos y vivienda social son los que han tenido una mayor participación. Esta realidad logra visibilizar por un lado la desigualdad existente en materia de acceso al suelo y vivienda, evidente en la emergencia de tomas masivas de tierra en 2005 y una consecuente expansión de la ciudad hacia el sur donde miles de familias han producido su hábitat desde entonces y, por otro lado, revela el rol que asumió el Estado local y provincial frente a una problemática que se presentó como acuciante: en el período, se sancionaron sucesivas 
leyes y ordenanzas de emergencia habitacional y el déficit habitacional entre 2001 y 2010 creció en un 49\% a nivel provincial (INDEC).

Las transformaciones institucionales que han vivido los gobiernos locales en los últimos veinte años y las innovaciones normativas que disponen como herramientas para la intervención en el proceso de producción urbana, los ubican en un lugar central en materia de desarrollo urbano y territorial. Las políticas públicas implementadas en las ciudades intermedias para resolver la problemática habitacional y de acceso a la ciudad en nuestro caso a partir de la experiencia del municipio de Río Grande, nos permiten indagar acerca de las alternativas existentes, los desafíos y las paradojas implícitas en ese accionar.

Considerando que cobra cada vez más relevancia en los estudios urbanos la perspectiva que recupera la mirada de la producción social del espacio (Harvey, 1977, 1994; Bourdieu, 2013; Lefebvre, 2013 y Soja, 2014 entre otros), este trabajo abrevado de esa perspectiva, pretende abonar la discusión para el caso de las ciudades intermedias de la región.

Enmarcado en una tesis de maestría y producto del trabajo investigativo principalmente a partir de metodologías cualitativas, nos proponemos dar cuenta de un tema poco abordado en la provincia y la región patagónica y donde el caso de estudio nos permite evidenciar las características de la relación entre política habitacional y política urbana local, los actores intervinientes, a la vez que permite reconocer y analizar las políticas habitacionales implementadas por el gobierno local en este sentido, las características de la ciudad producida en el periodo y las consecuencias de la implementación de las mismas.

\section{Palabras clave}

Política urbana; política de suelo y vivienda; expansión urbana. 


\section{Introducción}

El presente trabajo recupera y revisa algunos resultados del proceso investigativo desarrollado en torno de la tesis de Maestría en Desarrollo Local (Universidad Nacional de San Martín), cuyo título fue "La política municipal de producción de suelo y vivienda social en la región de la Patagonia Austral. El caso del municipio de Río Grande, provincia de Tierra del Fuego AIAS”. Allí se propuso dar cuenta del proceso de producción de suelo urbano y vivienda por parte del municipio de esa localidad en el marco más amplio de la política urbana en el periodo 2005-2015. El recorte temporal responde a una serie de hechos que han marcado ciertos mojones en el desenvolvimiento de las dinámicas de acceso al suelo y la vivienda en el territorio fueguino.

Hacia 2005 se produjeron una serie de tomas masivas de tierra en la zona sur de la localidad, y aunque no se trata del primer proceso de este tipo en la localidad, las tomas ocurridas en 2005 son las de mayor trascendencia de los últimos años. Este hecho colocó en la agenda pública una cuestión que fue abordada tanto desde la escala provincial como local. Hacia 2015, el período cierra con la puesta en marcha de acciones municipales innovadoras en materia de producción de suelo y vivienda; en definitiva, en el año 2015 se cierra un primer ciclo del viraje que tiene la política habitacional a nivel municipal en la ciudad (Finck, 2016). En este contexto, el objetivo que nos proponemos es el de poner de relieve el conjunto de decisiones que por acción u omisión ha tomado ese nivel de gobierno respecto de la cuestión urbana y en particular, aquellas inherentes a la promoción del acceso al suelo y la vivienda.

Nos centraremos entonces en identificar las características de la relación entre política habitacional y política urbana local, los actores intervinientes, así como también reconocer y analizar las políticas habitacionales implementadas por el gobierno local, las características de la ciudad producida en el periodo y las características que asumió 
la ciudad construida a partir del conjunto de dimensiones abordadas. Para ello recurriremos tanto a fuentes de información primaria (entrevistas, datos construidos a partir de fuentes secundarias) como de información secundaria (documentos públicos, normativa, información hemerográfica) relevadas para el caso, aplicando técnicas de investigación cualitativas. Siendo que ese trabajo recoge datos de una investigación previa, es menester anunciar que la misma será profundizada en lo venidero en el marco de los estudios de doctorado.

\section{Marco teórico/marco conceptual}

Si sostenemos que el espacio urbano es una producción social, política económica y simbólica, estamos asumiendo que el espacio urbano se produce a partir de la articulación de una serie de procesos donde intervienen actores y lógicas que se distinguen entre sí de acuerdo a los intereses y prioridades de sus procesos de producción; a su vez, como afirma Harvey (1977: 3) no solo "las formas espaciales contienen procesos sociales", sino también "que los procesos sociales son espaciales".

En lo que respecta a los actores productores de ciudad, son varios los autores que han abordado la cuestión (Herzer et al., 2004; Pirez, 2005; Rodríguez, 2007; Abramo 2008), en general se identifican al menos tres lógicas que guían el accionar de los actores configurando la ciudad capitalista: la lógica de la ganancia, la lógica de la necesidad y lógica de lo público (Herzer et al., 2004 en Rodríguez et al., 2007). Los contrastes socio-espaciales fueron a lo largo de la historia, de acuerdo a Reese (2011), una de las características centrales de la ciudad latinoamericana, combinando, como afirma Fernandes (2008), procesos de exclusión social y segregación espacial. En estas ciudades, la producción informal de ciudad -es decir aquella que se realiza por fuera de los 
mecanismos formales del estado o el mercado- es más bien una regla antes que una excepción. La desigualdad en el acceso a la ciudad alimenta entonces un proceso de exclusión social expresado en la estructura de las ciudades.

Los Estados que tienen como objeto privilegiado el territorio (Blanco, 2007) definen una serie de acciones respecto de la cuestión urbana, es decir, implementan políticas urbanas. Aquí se retoma la definición de Del Río, Vértiz y Ursino (2015: 83) quienes las entienden "como un conjunto de tomas deposición estatal que por acción u omisión inciden en el patrón de estructuración urbana y en las condiciones de vida u organización social”, los autores afirman que la forma de la acción puede ser implícita o explícita, formal e informal y que los posicionamientos del poder público no son unívocos ni homogéneos ni permanentes en el tiempo. Por otro lado, ese conjunto de decisiones "encuentra su origen, determinaciones y mediaciones en un entramado de actores mayor que se configura en torno de las cuestiones o los temas urbanos problematizados socialmente".

En este contexto de aumento de los grandes contrastes socio-espaciales, los gobiernos locales han asumido un rol preponderante en materia de responsabilidades respecto del crecimiento y desarrollo de las ciudades. Así, como afirma Reese (2011: 1) "los diferentes instrumentos de gestión y regulación urbanística son esenciales en la gestión de la tierra urbana en la medida que inciden directamente en la construcción y configuración del territorio”. Aquí abordaremos la cuestión urbana, en el marco de nuestros objetivos, en términos de procesos históricos que condensan distintas capas espaciales y niveles de implementación. Nos interesa indagar entonces sobre los procesos que devinieron en unas determinadas formas, materialidad y dinámica territorial de la localidad de Río Grande. 


\section{Metodología}

Este trabajo se inscribe en las metodologías cualitativas (Denzin y Lincoln [1994] en Wainerman y Sautu, 2001), complementándose con datos cuantitativos para comprender el contexto de las políticas urbanas y habitacionales implementadas y las transformaciones urbanas que surgen de ello. Para lo cual nos apoyamos en un estudio de caso (Coller; 2005), cuya forma de investigación es de carácter eminentemente empírico, lo cual se justifica a partir del tema y problema reconocido, como así también respecto de las preguntas que se generaron en ese marco. El análisis documental y la construcción de datos a partir de fuentes primarias (entrevistas a actores clave) y secundarias (documentos oficiales, normativa e información hemerográfica) constituyeron el grueso de las técnicas empleadas para el logro de los objetivos propuestos.

\section{Análisis y discusión de datos}

\section{Breve caracterización de la localidad de Río Grande}

La ciudad de Río Grande se ubica en la zona norte de la isla grande de Tierra del Fuego (provincia de Tierra del Fuego, Antártida e Islas del Atlántico Sur), en el extremo austral de la Patagonia argentina. Se trata de una ciudad de tamaño intermedio de acuerdo a su población. Según el último censo de población y hogares de Argentina (2010), la ciudad de Río Grande albergaba en ese año una población total de 70.042 habitantes, equivalente al 55\% del total de la población fueguina. Según Martínez (2017), a partir de un estudio de proyección de dinámicas demográficas, ese número ascendió en 2015 a 93.400 habitantes. 


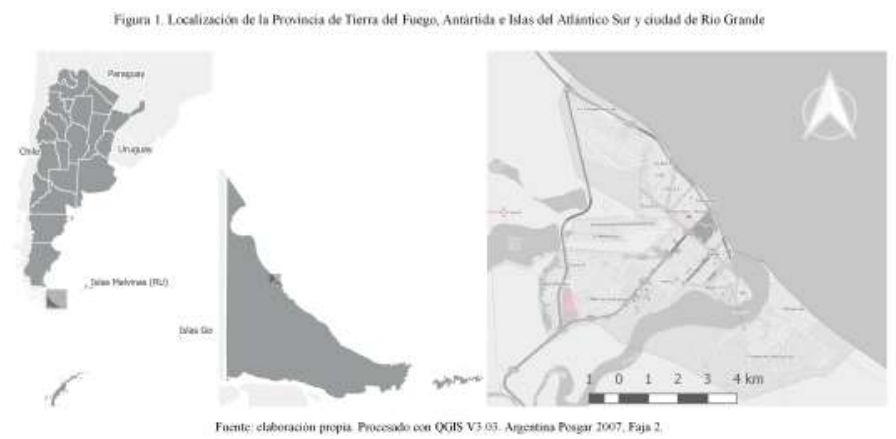

Río Grande fue fundada en 1921 como colonia agrícola y pastoril, sobre un antiguo asentamiento de comunidades originarias Shelk'nam. La Patagonia junto con Chaco fueron de los últimos territorios en ser incorporados a la órbita del Estado, lo cual se realizó bajo el estatus jurídico de "territorios nacionales", dándole una dependencia política y administrativa directa con el gobierno nacional (Cao y Vaca; 2006). Se radicaron allí primeramente expediciones en búsqueda de oro, para sucederle los emprendimientos agropecuarios y luego las actividades petrolíferas.

Las transformaciones que se sucedieron a partir de 1970 marcan un antes y un después en la historia fueguina y en la historia urbana de Río Grande, dado que se han impulsado una serie de políticas con el fin de promover la radicación de población en el territorio con un fundamento prioritariamente geoestratégico. El hecho más significativo fue la sanción de la Ley Nacional 19.640 que estableció para el territorio fueguino un régimen aduanero y fiscal especial que buscó promocionar el establecimiento de capitales industriales en particular de la industria electrónica, del plástico y textil. Sostendremos aquí que desde entonces, una serie de procesos se han mantenido constantes sobre los territorios locales fueguinos: 1) un crecimiento poblacional 
sostenido, 2) el desarrollo de políticas de vivienda y suelo tradicionales (Maldonado, 2009) y 3) la desregulación del mercado inmobiliario (Martinez, Finck, Lobato et al., 2017).

En materia de crecimiento poblacional, tal como se observa en la figura 2, este se mantuvo constante -aunque con una merma significativa durante los últimos añossuperando la media nacional durante los distintos censos desde 1970. El crecimiento poblacional, dados los procesos migratorios (el 65\% de la población residente no nació en la provincia [Hermida, Malizia y Van Aert, 2013]), y el crecimiento vegetativo propio de esta localidad (el 42\% de la población tiene entre 0 y 19 años de edad según el Censo de Población y Hogares 2010), demanda el acceso al suelo, la vivienda y la ciudad en general.

Figura 2. Tasa de crecimiento anual medio $(0 / 00)$ según periodo intercensal en provincias patagónicas y total país

Tasa de crecimiento anual medio $(0 / 00)$ según período intercensal en provincias patagónicas y total pais

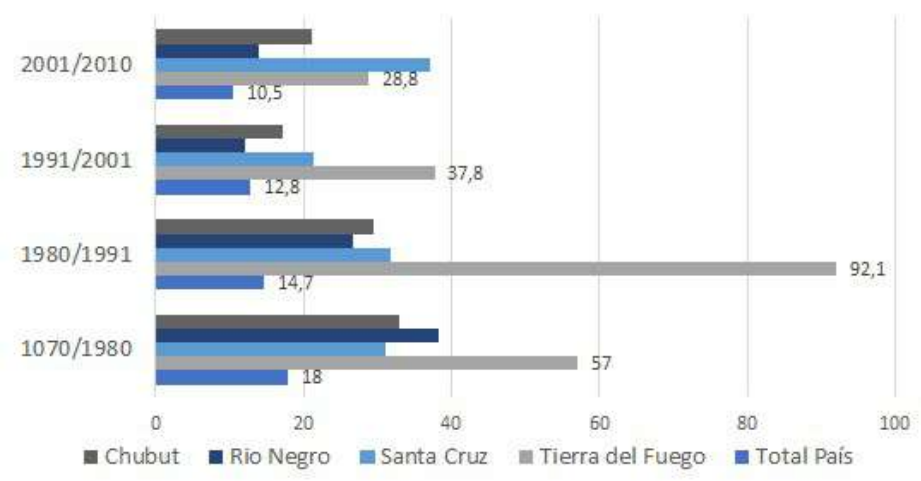

Fuente: Elaboración propia en base a encuesta permanente de hogares. Año 2016. 
Por otro lado, entendemos por políticas tradicionales de suelo y vivienda al conjunto de acciones estatales en materia de vivienda social y suelo que, transfiriendo grandes recursos a los propietarios de tierra, no logran solcuionar el problema social del acceso al suelo urbanizado, la vivienda ni/o la ciudad ${ }^{1}$ (Maldonado, 2009). En el caso fueguino, en términos generales podríamos afirmar que la política de suelo y vivienda estuvo centralizada exclusivamente por el poder central hasta 1996, momento en que el gobierno provincial traspasó las tierras nacionales a las órbitas municipales para que sean los propios estados locales quienes las administrasen. ${ }^{2}$

Hasta 2005 el municipio de Río Grande dispuso de la creación de una Dirección de tierras y un Banco de tierras como herramientas centrales de la política de acceso al suelo. Buscó así regularizar situaciones de tenencia irregular y administrar las tierras fiscales disponibles para su urbanización. Durante este periodo sí avanzó en materia de planificación, diseñando un Plan de Desarrollo Territorial (Código de planeamiento) que contenía una serie de propuestas innovadoras en materia de instrumentos de gestión y planificación del suelo (Reese, 2011). Sin embargo, este plan no entró en vigencia sino hasta 2011, momento en que se aprobó la ordenanza municipal nro. 2.863, otorgándole carácter de norma con plena vigencia.

1 Maldonado (2009) incluye entre las políticas tradicionales de vivienda social en América Latina a) la construcción estatal de vivienda; b) el otorgamiento de subsidios directos a la demanda en programas generalmente desarrollados por el sector privado o por una combinación de actuaciones públicoprivadas en las que se subsidia el acceso a la vivienda como producto terminado, y c) los programas paliativos de regularización de asentamientos de origen informal y de mejoramiento barrial (Maldonado; 327-328:2009).

2 Un primer antecedente en pos de la autonomía municipal se dio ya en los años 80 con la sanción de la ley territorial de municipalidades que establece que "corresponde a las municipalidades el gobierno y la administración de los intereses y servicios comunales del territorio nacional” (Ley Territorial 236, Artículo 1, TDF AIAS, 1984). 
Respecto de la desregulación del mercado inmobiliario, entendemos que allí incidió en principio la distribución de tierras fiscales que realizó el poder central en abundancia y baratas a grandes propietarios, lo que perfiló la organización social del espacio patagónico a partir de unas pocas grandes propiedades particulares y una baja densidad de población (Bandieri, 2011). Ello significó para el caso riograndense, una presencia anterior de actores privados y posterior de actores estatales (militar, por ejemplo).

La regulación del ordenamiento territorial que estuvo en manos del estado central y desde los años 80 ya a nivel jurisdiccional local, estuvo enfocada en la regulación de usos de suelo, la zonificación y en términos generales las pautas formales de la producción de suelo y vivienda. No se intervino directamente en el proceso de mercantilización del suelo, producto del mercado inmobiliario, con fines de redistribuir los beneficios del propio proceso de la urbanización. Esto no se modificó sino hasta el periodo 2011-2015 con algunos antecedentes destacados en el periodo 2005-2011.

Durante el periodo 2005-2015 una serie de transformaciones nos permiten identificar que el proceso de crecimiento poblacional continuó con la misma tendencia desde los años 70 aunque en menor intensidad, mientras que los otros dos procesos identificados (desregulación del mercado inmobiliario, políticas habitacionales tradicionales) presentaron discontinuidades aunque con notoriedad recién a partir del año 2012.

\section{Características generales de la ciudad producida}

Río Grande, al igual que muchas ciudades del país, se ha expandido (fuerte crecimiento de la superficie urbanizada) aunque no sucedió lo mismo con la población y como consecuencia se produjo una baja densidad (habitante por hectárea o habitante por km2). Para el caso de Río Grande, según el Atlas ID (2015), y entre 1991 y 2010, la localidad creció en su superficie un 132\% 
mientras que la densidad disminuyó en un 25\%. Por otro lado entre 2001 y 2010 la superficie servida mermó: de $98 \%$ a $89 \%$ del total de la superficie urbana que posee una "cobertura alta", indicador que surge de una sumatoria ponderada de servicios básicos por redes.

En lo que respecta al régimen de tenencia de la vivienda, según los datos del INDEC (2001 y 2010) y de acuerdo a los hogares, se percibe una disminución de la cantidad de hogares que son propietarios de la vivienda y el terreno en el año 2010 (58,10\%), respecto del año 2001 (64,04\%). Por otro lado, el estudio desarrollado en el Altas ID identifica que el caso de Río Grande en el periodo 2004-2013 fue el que demostró -en el caso de barrios consolidados- un fuerte empeoramiento de la accesibilidad al suelo, es decir que para el año 2013 se necesitaron una mayor cantidad de ingresos para acceder a una parcela tipo (300 metros cuadrados).

En Río Grande, siguiendo la tendencia del orden provincial, el déficit habitacional creció en el periodo 2001-2010. Respecto del déficit cuantitativo compuesto (total de hogares menos total de viviendas particulares habitadas [hogares excedentes], incorporando las viviendas irrecuperables), los valores absolutos y relativos se incrementaron entre estos años. En el caso de los valores relativos, estos tuvieron un incremento mucho mayor que a nivel provincial.

Déficit cuantitativo compuesto para Tierra del Fuego y Río Grande (años 2001 y 2010)

\begin{tabular}{|l|c|c|c|c|}
\hline & 2001 & 2010 & $\begin{array}{c}\text { Incremento } \\
\text { absoluto }\end{array}$ & $\begin{array}{c}\text { Incremento } \\
\text { relativo }\end{array}$ \\
\hline $\begin{array}{l}\text { Tierra del } \\
\text { Fuego* }\end{array}$ & 4.195 & 6.253 & 2.058 & $49 \%$ \\
\hline Río Grande** & 1.894 & 3.934 & 2.040 & $108 \%$ \\
\hline
\end{tabular}

* Datos tomados de Perez y Martinez (2014).

** Datos construidos a partir del Censo Nacional de Población, Hogares y Viviendas, 2001 (procesados con Redatam) y 2010. 


\section{Acción estatal local durante el período 2005-2015}

Entre 2000 y 2005 se produjo lo que Perez et al. (2015) caracterizaron como "una oclusión en el sistema de acceso a la propiedad de la tierra y de la vivienda, siendo ello un escenario propicio para el surgimiento de nuevos asentamientos en la provincia”. En efecto, como mencionamos, desde $2005^{3}$ se sucedieron una serie de tomas masivas que, en el caso de Río Grande, se localizaron en la zona sur de la localidad, configurando un nuevo proceso de expansión urbana bajo la modalidad prioritaria de la autoproducción del hábitat (Rodríguez et al., 2007: 22-29).

En el caso de Río Grande la política hacia los asentamientos fue la de tolerancia, por lo que no se produjeron desalojos sistemáticos como en la localidad de Ushuaia (Martinez y Finck, 2017). A nivel estatal local, el Estado municipal implementó durante todo el periodo una serie de acciones en materia de producción de suelo (Martinez, Finck, Lobato et al., 2017) y vivienda que constituyeron a nuestro entender el conjunto de acciones que perfilaron uno de los aspectos de la política urbana general.

La acción estatal local en materia de política urbana (Del Río, Vertiz et al., 2015:79) no fue homogénea en todo el periodo. Sostendremos aquí que es posible reconocer al menos dos subperiodos: 2005-2011 y 2012-2015, cada uno de ellos caracterizados por un rol diferencial que tuvo el municipio como actor productor de ciudad.

3 Desde ese año, el acceso al suelo y la vivienda se ha tornado una cuestión socialmente problematizada (Oszlak y O’Donell, 2011) aunque asumió en las localidades fueguinas un carácter distintivo. A nivel provincial se sancionaron una serie de leyes provinciales de emergencia urbano-ambiental que establecieron medidas en pos de atender la problemática que se presentó como acuciante: suspensión de desalojos, creación de un fondo de afectación específica para el cumplimiento de la ley, creación de una comisión de planificación, entre otras. 


\section{Subperiodo 2005-2010}

En el periodo 2005-2010 se destacan una serie de hechos que dotaron al municipio de un conjunto de herramientas para actuar en materia de planificación y definición de políticas urbanas y habitacionales en el marco de crisis caracterizado precedentemente.

En el año 2006, se sancionó la Carta Orgánica Municipal (COM) que estableció una serie de principios orientadores de la producción de ciudad definiendo cuestiones centrales como el desaliento de la especulación inmobiliaria (Artículo 63, COM). Ese mismo año, el Concejo Deliberante de la Ciudad de Río Grande sancionó la Ordenanza Municipal Nro. 2243/2006 creando con ella la Dirección Municipal de Vivienda cuyo principal objetivo era "el diseño, la definición e implementación de políticas y estrategias tendientes al mejoramiento de la situación habitacional de la ciudad". Sin embargo, la Dirección como tal no fue creada formalmente en el ámbito del Poder Ejecutivo Municipal así como tampoco se asignó presupuesto significativo a dicha partida, manteniéndose esta situación hasta el día de hoy.

En este periodo se realiza una urbanización estatal local (loteo) en la zona oeste de la ciudad, sobre una fracción de suelo incorporada como área urbana al banco de tierras municipal en 2004. El ingreso de esta tierra a la órbita pública se produjo a partir de un canje con un privado. En el año 2006 se aprueba un fondo para la urbanización de las tierras y en 2007 se hizo la entrega de los primeros 219 lotes aunque sin la totalidad de los servicios, como ser el gas. ${ }^{4}$ En el periodo se realizó también un nuevo canje de tierras con un privado en el extremo oeste de la ciudad, por

4 En el acto de adjudicación, el jefe de gobierno local (Ing. Jorge Martin, radicalismo), dirigiéndose a los recientes adjudicatarios manifestó "'ocupen de alguna manera, rápido, como puedan [el lugar], porque cada uno de ustedes tendrá la documentación y va a poder decir este lote es mío y les pedimos que nos den una mano porque lo tiempos son complicados y por eso esta necesidad de entregarlos aún sin el gas'" (El Diario del Fin del Mundo, 2007. Los corchetes son nuestros). 
fuera de la línea que hasta ese momento había funcionado como límite de consolidación y completamiento urbano (ruta complementaria de circunvalación nro 3). Dicha tierra es urbanizada en el siguiente periodo.

Asimismo, entre 2005 y 2010, se aprobaron ordenanzas relativas a un nuevo uso y ocupación de suelo: "residencial extra urbano" (zona norte de la ciudad); también se implementaron firmas de convenios para ejecutar programas federales de vivienda aunque ello se concretó en el siguiente período (zona oeste de la ciudad).

\section{Subperiodo 2011-2015}

Uno de los hechos más relevantes del periodo 2011-2015 implicó la puesta en vigencia del Código de Planeamiento (Plan de Desarrollo Territorial) (Ordenanza 2863/2011). La formulación de dicho Plan le permitiría al gobierno local, fijar los lineamientos generales y específicos del ordenamiento de la ciudad y su crecimiento. El mismo estableció los principios y las estrategias de actuación territorial, los programas y proyectos de acción respecto de él, como así también regula el uso, ocupación, subdivisión y equipamiento del suelo y determina el sistema de gestión territorial (Artículo 1, Ordenanza Municipal 2863). Asimismo, la ordenanza explicitó que se buscaba promover "la reducción de las desigualdades y de la exclusión social, facilitando el acceso a la tierra urbana, a la vivienda, a la infraestructura urbana, al transporte y a los servicios públicos tanto para las presentes como para las futuras generaciones".

Durante este periodo también se puso en vigencia el Código Tributario (Ordenanza N.o 2848/2010) que incorporó una serie de medidas relevantes para la movilización de suelo y la distribución de los beneficios generados en el marco del proceso de urbanización. Uno de ellos es la contribución por mejoras que deben aportar "quienes obtengan beneficios o plusvalías en los bienes de su propiedad, o poseídos a título de dueño, derivados directa o 
indirectamente de la realización de obras o servicios públicos determinados" (Ordenanza Municipal N. ${ }^{\circ}$ 2848, Art. 49; 2010). Este instrumento constituye un mecanismo de captación de plusvalías en el marco de lo dispuesto por la Carta Orgánica Municipal.

Asimismo se desarrolló el primer barrio municipal, a partir de un programa federal que supuso para su ejecución una articulación interjurisdiccional entre niveles de estado (federal, provincial, municipal). La disposición de la tierra y su acondicionamiento estuvo a cargo d el municipio, al igual que la gestión del Programa y su ejecución que se realizó a través de cooperativas. Esta experiencia supuso la construcción de 120 viviendas y oferta de 136 lotes servidos aunque en el caso de las viviendas se entregaron en 2014 y 2015 sin conexión de red de gas natural por lo que las familias estuvieron a cargo de la conexión de sistema de gas envasado -con costos mucho más elevados-.$^{5}$

Durante este periodo, asimismo, se realizó una urbanización municipal (Del Bicentenenario) compuesta por 150 viviendas terminadas y 300 lotes para gremios y viviendas, su localización fue el este de la ciudad. Se construyeron otras 20 viviendas en la urbanización de Chacra XI.

Por otro lado, se desarrollaron estrategias de articulación público-privado mediante la cual se generó un fideicomiso que ofreció en el mercado formal de suelo 1800 lotes; un convenio urbanístico con el gremio ATE de 260 lotes, quien está construyendo parte de las viviendas con fondos federales a través del gobierno provincial. Mediante

5 Algunas familias recibieron el acompañamiento estatal local a través de subsidios para la instalación del zeppelin para la provisión de gas envasado. Es importante destacar que las familias residentes del nuevo barrio realizaron distintas acciones de protesta para reclamar por servicios que identificaron como necesidades a resolver (servicio de recolección de residuos, transporte público de pasajeros, etc.). Entre las demandas que no lograron resolverse una fue el acceso al servicio de transporte público de pasajeros, por lo que los colectivos no ingresan al barrio; por otro lado, las obras de red de gas se construyeron en 2017, por lo que se prevé que las familias podrán contar con ese servicio para el invierno de 2018. 
la aplicación de los instrumentos tributarios, el municipio cuenta con un predio con capacidad de construcción de 812 viviendas. Estas últimas tres experiencias se localizan en la zona norte de la ciudad.

El municipio avanzó en el último periodo en acciones de regularización dominial de la zona sur, reordenamiento de barrios informales y provisión de obras de infraestructura básica para algunos barrios de esa zona. Se aprobaron ordenanzas para regular nuevas zonificaciones que habilitan al municipio a desarrollar acciones especiales orientadas a usos específicos: Zona Residencial de Interés Público Privada, ZRIPP (O. M. N. o 3287/14), a la vez que se generaron nuevas zonificaciones en la ciudad: Zona Especial de Interés Social (ZEIS) y Zona Residencial 5, ZR5 planes de vivienda del sector público.

En definitiva, durante este último período entendemos que la política urbana municipal en materia de acceso al suelo y la vivienda se diversificó, ampliando las posibilidades de acceso a estos bienes por parte de las familias habitantes de la ciudad. Sin embargo, resulta importante en este punto considerar la localización en tanto se trata de un producto social que al mismo tiempo es "un medio de acción que ejerce una coacción externa a las clases, grupos o individuos" (Del Río, Vertiz et al., 2015: 88). La localización genera efectos de lugar (Bourdieu, 2013) sobre las familias residentes de las distintas zonas del área de expansión.

Vivir en la periferia de las ciudades intermedias, a unos 8 o 9 kilómetros de distancia del centro de la ciudad, puede significar impactos distintos para las familias, no solo en relación a los niveles de ingresos que las familias perciben (costos más altos de traslado, acceso a bienes de consumo en el barrio más onerosos, etc.), sino y prioritariamente por las posibilidades o imposibilidades de acceso a los bienes y servicios urbanos que esas localizaciones les ofrezcan, como así también las externalidades que puedan o no ser apropiadas por las familias. Como ejemplo de esto, un conjunto habitacional sin acceso a un buen sistema de transporte 
público de pasajeros supone para las familias residentes una serie de operaciones en la experiencia urbana que, con la existencia de ese servicio, cualquier otra familia no debe realizar en áreas semejantes. ${ }^{6}$

\section{Conclusiones}

En este trabajo nos propusimos realizar un abordaje sobre las políticas públicas implementadas en las ciudades intermedias para resolver la problemática habitacional y de acceso a la ciudad a partir de la experiencia del municipio de Río Grande. Dimos cuenta de cómo durante los últimos años se ha producido una transformación del rol del municipio en materia de producción de suelo y vivienda. Luego de reconocer ciertas tendencias existentes desde la década de 1970 en materia de crecimiento poblacional, desregulación del mercado inmobiliario e implementación de políticas de suelo y vivienda tradicionales, aludimos a que la cuestión urbana en particular respecto del acceso al suelo y la

6 Si bien el sistema de transporte público de pasajeros ingresó al Barrio Los Cisnes a principios de 2018, de acuerdo a las entrevistas realizadas a residentes de la Urbanización del Barrio Los Cisnes en la localidad de Río Grande, los niños y niñas o adolescentes que ingresan a la escuela a las 7.30 de la mañana deben salir de sus casas a las $6 \mathrm{am}$, atravesar el barrio a pie, cruzar una ruta nacional (Circunvalación Ruta Nacional Nro 3, orientada a la circulación de camiones principalmente), atravesar doscientos metros de una zona en proceso de consolidación y esperar al ómnibus allí. El viaje de acuerdo al establecimiento educativo al que asistan (los más cercanos se encuentran a 1,9 km [Escuela Primaria Barrio Malvinas Argentinas (ex Chacra XI)] / 3,3 km [Barrio Malvinas Argentinas - Chacra XIII] / 3,7 km [Escuela Secundaria Barrio Malvinas Argentinas (ex Chacra XI)]); aun así estas instituciones educativas se encuentran en barrios de conjuntos habitacionales y de loteos sociales con capacidad colmada. El sistema de transporte público dificulta el acceso a las escuelas más cercanas, y respecto de otras escuelas de las ciudad, para llegar a destino, los/as usuarios/as deberán utilizar dos ómnibus diferentes para llegar a su destino. 
vivienda se posicionó como un tema ineludible para el Estado en sus diferentes escalas. Algunas de estas tendencias pudieron ser modificadas.

Desde el punto de vista de los gobiernos locales, estos tuvieron posibilidades de incidir directamente sobre las últimas dos tendencias mencionadas (desregulación del mercado inmobiliario e implementación de políticas de suelo y vivienda tradicionales) en el periodo 2005-2015. Aun así, como hemos visto, muchas de las acciones estuvieron supeditadas a la aprobación con rango normativo de instrumentos como ser el Plan de Desarrollo Territorial (que demoró en sancionarse 10 años) o el Código Tributario. Asimismo, contar con instrumentos en el plano normativo no significa, como hemos notado, su aplicación efectiva necesariamente; ejemplos de ello lo constituyen la creación de la Dirección Municipal de Vivienda (DIMUVI) por ordenanza, la cual nunca fue puesta en funcionamiento.

Por otro lado, hemos notado cómo las distintas acciones estatales en materia de producción de suelo y vivienda se localizaron de manera diferenciada en la ciudad: las estrategias tradicionales de producción de suelo (loteo con o sin servicios) y construcción de vivienda social se localizaron en la zona oeste de la ciudad. La disponibilidad de tierra con fines habitacionales (Banco de tierras) se produjo con exclusividad a través del sistema de canje con privados, que ofrecieron tierras al municipio en esa zona de la ciudad (sobre algunas de ellas hubo que realizar un cambio de uso (de rural a urbano), en áreas desconectadas de la trama urbana consolidada y que con los años se han ido urbanizando.

Las urbanizaciones del segundo período (2011-2015) se localizaron en esas parcelas ingresadas al banco de tierras municipal durante el primer periodo. Este hecho consolidó el beneficio de los propietarios de las áreas intersticiales de las urbanizaciones desarrolladas por el estado a la vez que abonó el proceso característico de ciudades intermedias: expansión de la mancha urbana con baja densidad. 
Por otro lado, las estrategias de asociación públicoprivada (generación de loteos con privados) ${ }^{7} \mathrm{y}$ adquisición de tierras en el marco del instrumento de contribución por mejoras, se localizaron en la zona norte de la ciudad. En el primer caso, las obras de urbanización estarían finalizadas para 2018 y para poder acceder a los lotes ofrecidos fue necesario que las familias contasen con capacidad de ahorro previo y de sostenimiento de cuotas mensuales en el marco de un plan de pagos propuesto por el privado.

Las acciones del gobierno municipal en materia de acceso al suelo y la vivienda acompañaron, en el marco de los procesos de transformación urbana de los últimos años, la localización preponderante de ciertos tejidos residenciales por zona en la localidad. Diremos que en general, el estado local acompañó los siguientes procesos: la localización preponderante de iniciativas privadas en la zona norte; la radicación preponderante de la vivienda social pública o loteo social en la zona oeste de la ciudad y la localización preponderante de la vivienda y urbanización autoproducidas sobre asentamientos, en la zona sur. De continuar estas tendencias, se reforzaría una ubicación diferencial en la ciudad de acuerdo a la posición en la estructura social que tengan los habitantes (Finck, 2016).

Resulta prioritario en este sentido considerar las miradas de los usuarios y usuarias destinatarios/as de las políticas de vivienda, incorporando la localización como una dimensión ineludible de las mismas. Estas políticas en perspectiva de política urbana integral no debieran estar escindidas de aquellas relacionadas con cuestiones centrales del habitar urbano como es el sistema de transporte, los equipamientos comunitarios y las infraestructuras básicas. Ello, a los fines irrenunciables de garantizar que el acceso a la vivienda sea al mismo tiempo el acceso a la ciudad.

7 Ello fue posible gracias a la creación de la Zona Residencial de Interés Público Privado (Ordenanza N.o 3287/2014). 


\section{Bibliografía}

Abramo, P. (2008). El mercado del suelo informal en favelas y la movilidad residencial de los pobres en las grandes metrópolis: un objeto de estudio para América Latina. Territorios, $\mathrm{N}^{\circ} 18-9$, enero-diciembre, pp. 55-73. Bogotá, Colombia.

Bandieri, S. (2011). Historia de la Patagonia. Buenos Aires: Ed. Sudamericana.

Blanco, J. (2007). Espacio y territorio: elementos teóricoconceptuales implicados en el análisis geográfico. En Fernández Caso, M.V. - Gurevich, R. (coord). La geografía y sus discursos. Un temario para la enseñanza. Ed. Biblos.

Bourdieu, P. (2013). La miseria del mundo. Buenos Aires: Fondo de Cultura Económica.

Cao, H. y Vaca, J. (2006). Desarrollo regional en la Argentina: la centenaria vigencia de un patrón de asimetría territorial. Revista EURE, vol. XXXII, N. ${ }^{\text {o } 95, ~ p p . ~}$ 95-111. Chile. Coller, X. (2005). Estudio de casos. Centro de Investigaciones Sociológicas. Madrid.

Del Río, J. P., Vértiz, F., Ursino, S. (2014). La acción pública en el espacio urbano. Debates y reflexiones en torno a la noción de política urbana. Revista Estudios Sociales Contemporáneos (11), pp. 76-86.

Fernandes, E. (2008). Consideraciones generales sobre las políticas públicas de regularización de asentamientos informales en América Latina. EURE (Santiago), vol. 34, N.o 102, pp. 25-38. Santiago, Chile.

Finck, N. (2016). Políticas municipales de producción de suelo y vivienda: el caso del municipio de Río Grande (Pvcia. de Tierra del Fuego, Antártida e Islas del Atlántico Sur [AIAS]) (en línea). Trabajo presentado en IX Jornadas de Sociología de la UNLP, 5 al 7 de diciembre de 2016, Ensenada, Argentina. 
Finck, N.; Lobato, S.; López, J.; Martínez, A.; Moreno Russo, F. (2016). Las ciudades fueguinas en perspectiva comparada: Un análisis de las políticas de producción de suelo y vivienda en Ushuaia y Río Grande, durante la última década (2005-2015) (en línea). Trabajo presentado en IX Jornadas de Sociología de la UNLP, 5 al 7 de diciembre de 2016, Ensenada, Argentina.

Harvey, D. (1977). Urbanismo y desigualdad social. Madrid: Siglo XXI Editores.

Hermida, M., Malizia, M. y Van Aer, P. (2013). Migración en Tierra del Fuego (o la historia de una ida y una vuelta). Revista Sociedad Fueguina, $\mathrm{N}^{\circ}$ 02, año 01, noviembre de 2013. Instituto de Cultura Sociedad y Estado Universidad Nacional de Tierra del Fuego, Antártida e Islas del Atlántico Sur.

Lefebvre, H. y Lorea, I. M. (2013). La producción del espacio. Madrid: Capitán Swing.

Maldonado Copello, M. M. (2009). ¿Es posible anticiparse a la urbanización informal? Reflexiones a partir de la Operación Urbanística Nuevo Usme, Bogotá y del Macroproyecto Ciudadela Gonzalo Vallejo Restrepo, Pereira (Colombia). Regularización de asentamientos informales en América Latina. Cambridge: Lincoln Institute of Land Policy.

Martínez, A.; Finck, N. (2017). La política de desalojos en el fin del mundo: el caso del Municipio de Ushuaia, Argentina, en el período 2007-2015. Revista Ciudades, Estados y Política [s. 1.], vol. 4, $\mathrm{N}^{\circ} 1$, pp. 59-78, ene. Disponible en: https://bit.ly/2XuUvMn.

Martinez, A.; Finck, N.; Lobato, S. y Moreno Russo, M. F. (2017). El suelo público para qué y para quiénes: distribución de tierras fiscales en Tierra del Fuego (2005-2015). XII Jornada de Sociología, 22 al 25 de agosto. Universidad Nacional de Buenos Aires. Mesa 75: Territorios, políticas habitacionales y centralidades urbana. Buenos Aires. 
Martinez, S. (2017). Modelo de proyección de necesidades basado en dinámicas demográficas, para la gestión integral del hábitat. Provincia de Tierra del Fuego, Antártida e Islas del Atlántico Sur. Informe final. Consultor 3 Sistemas de Información geográfica. Anexo cartográfico. Subsecretaria de Planificación Territorial de la Inversión Pública. Programa de fortalecimiento institucional préstamo caf 7353. Disponible en https://bit.ly/2ESjsKb.

Reese, E. (2011). Instrumentos de gestión urbana, fortalecimiento del rol del municipio y desarrollo con equidad. En revista digital Carajillo de la ciudad. Revista digital de Programa en Gestión de la Ciudad. UOC y Café de las Ciudades, año 3, octubre.

Pérez, V.; Debia, E.; Lobato, S. et al. (2015). Políticas habitacionales y mercado del suelo: asentamientos informales en Tierra del Fuego. Ponencia presentada en Seminario Internacional: el Derecho a la Ciudad en América Latina: transformaciones económicas y derecho a la ciudad. Universidad Nacional de General Sarmiento, Facultad de Ciencias Sociales de la UBA y el GT-DC de CLACSO. 24 y 25 de abril de 2015. Buenos Aires.

Pírez, P. (1995). Actores sociales y gestión de la ciudad. En Ciudades, Red Nacional de Investigación Urbana, año 7, N. ${ }^{\circ}$ 28, octubre-diciembre. México.

Rodríguez, M. C.; Di Virgilio, M. M.; Procupez, V.; Vio, M.; Ostuni, F.; Mendoza, M. y Morales, B. (2007). Política del hábitat, desigualdad, y segregación socioespacial en el Área metropolitana de Buenos Aires. AEU-IIGG/FSOC-UBA Área de Estudios Urbanos Instituto de Investigaciones Gino Germani Grupo Argentina de Producción Social del Hábitat hic-al FVC-MOISEDECA. Buenos Aires.

Soja, E. (2014). En busca de la justicia espacial. Valencia: Ed. Tirant lo Banche. 
Subsecretaria de Planificación Territorial de la Inversión Pública (2015). ATLAS ID, Indicadores de Desarrollo Territorial de la República Argentina. Recuperado de http://atlasid.planificacion.gob.ar/

Wainerman, C. y Sautu, R. (comp.) (2001). La trastienda de la investigación. Buenos Aires: Ediciones Lumière. 



\title{
Brasil e Uruguai: duas experiências de modernização e de habitação de interesse social na América Latina no início do século XXI
}

\author{
TIAGO VIEIRA RODRIGUES DUMONT
}

\section{Resumo}

Este trabalho tem por objetivo fazer uma análise comparada da política habitacional surgida no Brasil e Uruguai no contexto geopolítico mundial Pós-Guerra Fria. Tendo como horizonte uma perspectiva sociológica, propomos refletir se as políticas habitacionais adotadas pelo Estado e/ou governo, tanto no Brasil como no Uruguai, apontam alguma solução para os problemas urbanos enfrentados pela população de baixa renda do continente no início do século XXI, assim como se elas retratam todo um campo debate econômico, político e social de uma época. A análise da política habitacional, no Brasil, voltada para a população de baixa renda depende das diretrizes do governo que, por sua vez, é mantida pelas regras do mercado, ou seja, pela contradição do sistema. Programas como o "Minha casa, Minha vida", permitem compreendermos como tem sido resolvido o acesso à casa própria ou do sonho da casa própria nessa realidade, à medida que, apontam para a extensão da segregação e das desigualdades urbanística. Feito isso, falaremos sobre a questão fundiária e como a adoção de uma política habitacional a partir da autogestão e de cooperativas produziu uma ideia de pertencimento, de povo e de nação para aqueles que estiveram à margem desse processo de "modernização" do Uruguai. Por fim, buscaremos 
destacar como a emergência do Estado democrático de direito e de atores sociais ligados ao campo da esquerda e/ ou progressista foram capazes de produzir elementos norteadores para uma "nova" política urbana e habitacional, tanto no Brasil, como no Uruguai. Para isso, realizaremos um estudo comparativo entre as políticas urbanas, mas, sobretudo, das políticas habitacionais criadas e/ou instituídas pelos governos da Frente Amplio (no Uruguai) e pelos governos do Partido dos Trabalhadores (no Brasil). Deste modo, buscaremos destacar os impactos dessas políticas sobre o desenvolvimento dos demais países na América Latina. Uma das nossas hipóteses seria que a implementação do modelo habitacional urbano-industrial e/ou empresarial no Brasil, de um lado, e o modelo de autogestão no Uruguai, por outro, apontam caminhos distintos, que, no devir, construíram contextos semelhantes no que tange a sua modernização e organização, revelando, assim, os limites e os possíveis da política habitacional, para população de baixa renda, na América Latina.

\section{Palavras-chave}

Projetos Nacionais; Habitação de Interesse Social; Pensamento Social Latino-Americano.

\section{O labirinto latino americano}

Sob a disseminação do ideário e práticas neoliberais conjugados ao processo de globalização, as nações latinoamericanas são conduzidas, no início do século XXI, a mais um período modernizador, ou seja, à superação do que foi chamado de década perdida (o período de 1980-1990). O caminho foi norteado pela desregulamentação da economia, privatização tanto de empresas estatais como de serviços públicos, abertura do comércio interno, Estado mínimo para as políticas sociais e máximo para o capital financeiro, 
livre comércio e inserção associada à economia globalizada. Essa plataforma supostamente modernizadora foi apresentada como redentora dos graves problemas econômicos, sociais, políticos e do desenvolvimento da América Latina. Os países latino-americanos procuravam adequar-se ao modelo europeu seguindo suas linhas de mudanças e, por outro, sofriam as transformações, derivadas de sua estrutura interna, das relações entre os diferentes grupos (Romero, 2004). A região é caudatária de uma história colonial e de processos de independência que efetivamente não romperam os laços de dependência ou os recriaram sobre outras formas.

Segundo Constanza Moreira (2000), Brasil e Uruguai, representam dois casos relativamente opostos em termos da consolidação e da institucionalização de um sistema político democrático: o Uruguai é uma das democracias mais velhas do continente e o Brasil, uma das mais recentes. Em ambos os países, essa conjuntura foi definidora para consolidação dos partidos de esquerda na América Latina, em particular, do Partido dos Trabalhadores (PT) e da Frente Ampla (FA). No Brasil, o PT nasce em 1979, na transição para a democracia e é anterior à consolidação da Central Única dos Trabalhadores (CUT), 1983. No caso do Uruguai a FA surge em 1971 e marca uma reação à decadência econômica e política, em um processo organizado pela sociedade, por meio do sindicalismo, que conformou na Convenção Nacional dos Trabalhadores (CNT) em 1964. Tal processo culminou, anos depois, com chegada do PT e da FA ao poder ou governo federal, respectivamente em 2004 e 2005, o que possibilitou a retomada no continente de políticas públicas com viés desenvolvimentista, ou seja, de experiências próximas à imagem de um Estado de bem-estar social.

Nesse sentido, buscamos problematizar como a adoção de uma "nova" política habitacional, tanto no Brasil quanto no Uruguai, são expressões do desenvolvimento possível para os países da América Latina. Ou seja, como 
os governos do PT e da FA buscaram produzir políticas que possibilitaram a retomada do debate e de ações que se propuseram a romper com os laços do "desenvolvimento associado dependente". O fortalecimento e o desenvolvimento do Estado pareciam os instrumentos necessários para alcançar uma política de desenvolvimento (Cardoso e Faletto, 1977). É partindo deste contexto que este estudo - em curso - tenta discutir e depreender a relação de dependência, independência e interdependência desse continente, assim como os dissonantes caminhos de inserção a modernidade.

Os antigos súditos converteram-se em devedores perpétuos do sistema econômico internacional. Poderosa e onipresente, uma engrenagem invisível comanda o novo sistema. Não raro, ela revoga decisões democráticas, desidrata a soberania dos estados, sobrepõe-se a governos eleitos. Exige a renúncia a legítimos projetos de desenvolvimento nacional (Silva, p. 2, 2004).

As palavras do ex-presidente do Brasil, Luis Inácio Lula da Silva, na Assembleia da ONU apontam para as dificuldades enfrentadas por boa parte dos países da América Latina na tentativa de desenvolverem não só seus territórios, mas uma visão própria de sua história. Revelam como a formação das nações latino-americanas foi ou é marcada por um longo período de colonização, para em seguida buscar a independência associada por uma dependência. Desse modo, os países latino-americanos enfrentam duas realidades ásperas. Uma é a capacidade de absorção das transformações do capitalismo pelas estruturas econômicas, socioculturais e políticas, o que segundo Florestan Fernandes (1973), impede a integração nacional e o desenvolvimento autônomo. O outro é a modernização estimulada pela dominação externa, mas que impede a revolução nacional e uma real autonomia. Para Carla Giaudrone (2000, p. 259): 
El modernismo latinoamericano surge dentro del contexto histórico de los grandes cambios económicos (fin del pacto colonial, industrialización, surgimiento de nuevas estructuras económicas) y sociales (fenómeno de la inmigración, democratización) ocurridos al final del siglo XIX. Ante el avance de nuevos productos de la ciencia y la industria y la entrada de tecnologías masivas como la prensa, los modernistas adoptan una actitud que vacila entre la búsqueda de universalidad, encarnada en el ansia de participar en un mundo cosmopolita y moderno, y el recelo a una modernidad cuyo rasgo más sobresaliente en Hispanoamérica reside en la propia conciencia de su fragilidad o, como señala Roberto González Echeverría, de su falsedad.

O desmonte levado adiante pelas políticas neoliberais reflete no enfraquecimento, mais intensamente, dos Estados periféricos do sistema internacional. Na América Latina, esse processo, produziu (Ffrench-Davis; Muñoz; Palma, 2005, p. 228-7):

De uma ativa intervenção na alocação de recursos e nas atividades produtivas diretas até a década de 70, o papel do Estado passou a restringir- se à política macroeconômica, à construção de infraestruturas e a programas sociais. Contudo, no processo de reformas e ajustes, foi fortemente enfraquecida a capacidade do Estado de desempenhar até mesmo seu novo papel, muito mais limitado. Em consequência, surgiu uma incoerência entre a capacidade do Estado reformado e a necessidade, imposta em grande medida pela profundidade da "crise social" e pela transição de governos democráticos em toda a região, de seguir uma estratégia de desenvolvimento com equidade.

Para Décio Saes (2001, p. 83), os Estados capitalistas atuais praticam o neoliberalismo possível nas condições socioeconômicas e políticas vigentes. Ou melhor, produz um capitalismo com forte presença estatal, de distribuição da renda sem confronto (Singer, 2012, p. 110). Sendo assim deixada de lado a política nacionalista para crescente relação público-privado. Segundo Celso Furtado (1998, p. 29): 
O processo atual de globalização a que assistimos desarticula a ação sincrônica dessas forças que garantiram no passado o dinamismo dos sistemas econômicos nacionais. Quando mais escapam da ação reguladora do Estado, mais tendem a se apoiar nos mercados externos para crescer. Ao mesmo tempo, as iniciativas dos empresários tendem a fugir do controle das instâncias políticas. Voltamos assim ao modelo do capitalismo original, cuja dinâmica se baseava nas exportações e nos investimentos estrangeiro.

Quando analisamos, por exemplo, o processo de constituição da política urbana e habitacional de países como o Brasil e Uruguai, percebe-se que ela resultou de um processo histórico que busca a eliminação dos pontos de "estrangulamento" da economia. Ou seja, de como o Estado foi capaz de articular as necessidades nativas com o desenvolvimento hegemônico do capital. Essa forma de reprodução do capital no modo de produção capitalista reforça e aprofunda a valorização do mercado imobiliário, mesmo que de modo artificial, sendo favorável para os detentores do capital e extremamente desastrosa para população de baixa renda, que é carente de moradia urbanizada e digna. Podemos afirmar de imediato que as consequências são extremamente danosas para a população de baixa renda, pois tal dinâmica força uma valorização do mercado de terras urbanizadas e, de um modo geral, obriga a que essa população com menor renda busque moradia em locais aonde o processo de valorização do solo ainda não chegou de forma acentuada.

\section{As cidades latino-americanas sob o contexto neoliberal}

A cidade se constituiu em mais um espaço e lugar de disputas sociais no capitalismo contemporâneo. Pois suas constantes transformações indicam os interesses que com- 
põe a construção e a desconstrução desse local. Deste modo, podemos compreender, como as disputas entre os diferentes e diversificados segmentos da sociedade latinoamericana orientam a constituição das políticas habitacionais e de como "las políticas urbanas constituyen la dimensión espacial del Estado y la regulación de la división económica y social del espacio" (Barenboim e Agudelo, 2007, p. 170).

Este debate pode ser compreendido a partir da tensão social entre a "cidade oficial" e a "cidade ilegal". À cidade oficial cabe o planejamento modernista/funcionalista definido pelos padrões importados dos países centrais do mundo capitalista, já para a cidade ilegal não existe ordem, nem planos. É a utilização da representação ideológica como um instrumento de poder que, como representação da cidade, encobre a realidade científica, reafirmando e reproduzindo desigualdades e privilégios (Maricato, 2000). Desse modo, a cidade se constituirá no resultado da concentração da força de trabalho e do capital (Somekh, 1997).

Foi no bojo da Revolução Industrial que as cidades passaram por profundas mudanças sociais, econômicas e políticas, ou melhor, rompem com a união entre civitas e urbs, entre campo e cidade. Portanto é sobre os impactos desse importante fato histórico que será produzida a matriz de planejamento urbano modernista/funcionalista, que irá moldar o desenvolvimento urbano durante o século XIX e início do XX. É a construção, ou melhor, a produção capitalista da casa e da cidade, na qual se configura a ideia da "terra urbana como capital". Segundo, Françoise Choay, as teorias sobre urbanização irão se dividir em duas: a primeira seria o modelo progressista, no qual se busca o progresso e a produtividade, a segunda, é baseada no modelo culturalista, pois visa o humanismo. Essas teorias tornaram-se, durante esse período, pilares no desenvolvimento das cidades. No entanto, com o avanço do ideário neoliberal em conjunto 
com a reestruturação produtiva no final do século $\mathrm{XX}$, esse modelo teórico passou a ser desmontado. É a emergência do modelo taylorista-fordista. Segundo Raquel Rolnik:

A lógica capitalista passa a ser então um paramento essencial na condução de uma política de ocupação da cidade, que se expressa também na intervenção do Estado. Para exercer esta intervenção, todo um aparelho de Estado vai ser organizado (1994, p. 54).

Se transportarmos esse debate para os países da América Latina, será possível apontar algumas aproximações, à medida que verificamos processos semelhantes de transformação do espaço e do habitar da cidade, principalmente em grandes cidades, como São Paulo, Buenos Aires, Montevidéu, Bogotá, Santiago, Quito, Cidade do México, entre outras. Para Cintia Barenboim e María Agudelo (2007, p.171), o processo de produção de políticas urbanas e habitacionais na América Latina está orientado pela:

[...] reestructuración económica mundial, el proceso de modernización del Estado y las políticas de ajuste implementadas agudizaron los desequilibrios regionales, en particular las desigualdades históricas, características de las ciudades latinoamericanas. Lo antedicho se ve reflejado en las políticas habitacionales: el caso de la legislación uruguaya sobrelleva un proceso evolutivo comparable con el que ha ocurrido en otros países de América Latina, como Chile y Argentina. Sin embargo, posee características particulares que se desarrollan a lo largo del artículo.

Foi, portanto, a partir da segregação do espaço social que parte das cidades latino-americanas, como São Paulo e Montevidéu, foram produzidas. A cidade, ao aglomerar num espaço limitado uma numerosa população, cria mercado. E assim se estabelece não apenas a divisão social do trabalho entre campo e cidade, mas também uma especialização do trabalho no interior da cidade (Rolnik, 1994). Esta 
seria, segundo Barenboim e Agudelo (2007, p. 178), uma política que atinge principalmente as camadas mais pobres das cidades, à medida que:

[...] han contribuido a fortalecer la segregación socioespacial en territorio nacional, según la cual las personas con menos recursos se ven obligadas a habitar las áreas periféricas de las ciudades, generalmente carentes de los servicios y la infraestructura necesaria para garantizar una vivienda digna, así como a "reciclar" o, en casos más extremos, a "tomar" casas abandonadas del centro de las ciudades, donde ya las personas de las clases media alta y no viven, porque se mudaron a los suburbios. Contrariamente, los sectores de la sociedad con los recursos financieros necesarios para respaldar deudas $\mathrm{y}$ acceder a viviendas particulares son favorecidos por estas políticas de desregulación del mercado.

É diante deste contexto que será possível observar como as políticas habitacionais, tanto no Brasil quanto no Uruguai, buscaram produzir um enfrentamento ou articulação com o capital. No caso brasileiro, uma nova estratégia para a política urbana e habitacional foi produzida entre o final do segundo mandato do governo Fernando Henrique Cardoso - FHC - (1998-2002), ligado ao PSBD - Partido da Social Democracia Brasileira - e o início do governo Luís Inácio Lula da Silva, ligado ao PT (2002-2004). Em 2001, após 13 anos de discussão, foi aprovado pelo congresso e promulgado pelo então presidente FHC, o Estatuto da Cidade. Ao estabelecer diretrizes para a regulamentação dos diferentes usos e ocupação do espaço urbano, o Estatuto, marcou em um primeiro momento a possibilidade de regulamentação da função social da propriedade após um período de interrupção na formulação de propostas para política urbana e habitacional do Brasil e, em um segundo momento, ao tornar-se um marco importante na passagem 
do governo de FHC para o governo Lula ${ }^{1}$, à medida que utilizava-se de uma proposta do Projeto Moradia e traçava os desafios que deveriam ser colocados em prática pelo novo governo, enfrentando assim, problemas considerados históricos na política urbana e habitacional do país.

Como resultado dessa estratégia, temos, em 2003, a criação do Ministério das Cidades, demonstrando assim, a centralidade que a questão urbana e habitacional deveria assumir. E em 2009, no segundo governo Lula, por meio do PAC 1 (Programa de Aceleração do Crescimento), é criado o Programa "Minha Casa, Minha Vida" - PMCMV, uma das suas finalidades foi promover a concessão de financiamento para construção de 1 milhão de unidades habitacionais, para famílias com renda mensal de até 10 (dez) salários mínimos, totalizando um investimento inicial de R\$ 34 bilhões. Desse total, R \$ 25,5 bilhões seriam provenientes da União, R\$ 8,5 bilhões do Fundo de Garantia por Tempo de Serviço (FGTS) e mais R\$ 1 bilhão do Banco Nacional de Desenvolvimento Econômico e Social (BNDS) para a cadeia produtiva (Brasil, 2009). A execução e operacionalização do Programa ficariam a cargo de seus agentes financeiros, Caixa Econômica Federal - CAIXA e o Banco Nacional de Desenvolvimento Social - BNDES ${ }^{2}$, sendo a Caixa o gestor do FGTS. ${ }^{3}$

A partir de 2011, com a eleição de Dilma Rousseff, o PMCMV, é inserido no Programa de Aceleração do Crescimento - PAC 2 (2011-2014), onde tem seus recursos, bem

1 Com a eleição, em 2002, para a presidência do Brasil, de Luis Inácio Lula da Silva, através do Partido dos Trabalhadores (PT), vivenciou-se uma euforia com os possíveis rumos da política urbana e habitacional do país. A partir das discussões e experiências das administrações municipais do PT, uma nova expectativa ocorreu quanto a ocupação institucional do governo federal na discussão e criação de política urbana e habitacional a ser implementada no país.

2 Ainda em 2011, o Banco do Brasil, também passou a operar os recursos do PMCVM.

3 Dados apresentados no folheto de divulgação do Programa e do site: www.minhacasaminhavida.gov.br. 
como suas metas ampliadas no que tange \{a produção de moradias, tendo como nova meta a construção de 2 milhões de moradias com recursos que contabilizam um montante de $\mathrm{R} \$ 71,7$ bilhões. Sendo assim quando o Governo Federal cria o Programa MCMV teria como objetivo declarado, segundo Pedro Arantes e Mariana Fix (2009, p. 1):

[...] dirigir o setor imobiliário para atender à demanda habitacional de baixa renda, que o mercado por si só não alcança. Ou seja, é fazer o mercado habitacional finalmente incorporar setores que até então não tiveram como adquirir a mercadoria moradia de modo regular e formal.

Além desse objetivo o Programa, Arantes e Fix (2009, p. 1), afirmam:

[...] tem sido apresentado como uma das principais ações do governo Lula em reação à crise econômica internacional ao estimular a criação de empregos e de investimentos no setor da construção -, e também como uma política social em grande escala. $\mathrm{O}$ volume de subsídios que mobiliza, 34 bilhões de reais (o que equivale a três anos de Bolsa-Família), para atender a população de 0 a 10 salários mínimos de rendimento familiar, é, de fato, inédito na história do país - nem mesmo o antigo $\mathrm{BNH}$ dirigiu tantos recursos à baixa renda em uma única operação.

De um modo geral, segundo o governo, o Programa seria duplamente atraente: estimularia a economia com uma medida anticíclica para um período de crise financeira mundial, gerando empregos e aquecendo a economia nacional, e enfrentaria uma questão social histórica da sociedade brasileira, que é a total precariedade das moradias da população de baixa renda, atacando essa problemática por meio da reposição de estoque de moradias. Ou seja, os governos do PT, representaram, segundo André Singer (2016, p. 31) uma combinação de ideias - "reforma gradual e pacto 
conversado", à medida que, mantinha a expectativa de um Estado suficientemente forte para diminuir a desigualdade, mas sem ameaçar a ordem estabelecida.

A análise da política habitacional, no Brasil, voltada para a população de baixa renda depende das diretrizes do governo que, por sua vez, é mantida pelas regras do mercado, ou seja, pela contradição do sistema. Programas como o "Minha casa, Minha vida", criados e implementados, sob a gestão dos governos Luis Inácio Lula da Silva e Dilma Rousseff (ambos ligados ao Partido dos Trabalhadores), permite compreender como tem sido resolvido o acesso à casa própria ou do sonho da casa própria nessa realidade à medida que aponta para a extensão da segregação e das desigualdades urbanística. Essa situação indica o deslocamento do problema de demandas de novas habitações na cidade para demandas de melhorias do habitar no meio urbano, embora esteja mantida a gênese da desigualdade socioespacial.

Processo semelhante ocorreu com o Uruguai, desde o momento, que se instituiu o Plan Quinquenal de Vivienda e, que o Congresso, em 1968, promulgou a Ley de Vivienda (Lei no 13.728), associando de vez o desenvolvimento do mais importante marco legal da urbanização no país ao processo modernizador, visto que ele estava ligado à consolidação da urbanização e da promoção de um Estado de bem-estar social no país. Foi a partir deste momento que as cooperativas ${ }^{4}$ passaram a ter uma centralidade no processo

4 Segundo, Eduardo Bavarelli (2006, p. 55-6), em meados do século passado, o ciclo de reformas mordenizantes do "batllismo" transformou o Uruguai na imagem mais próxima que a América Latina teria de um Estado de bemestar sócia. O "batllismo" se torna uma corrente hegemônica dentro do partido Colorado para representar os interesses da classe média urbana e imigrante contra o Partido Blanco, dominado por proprietários de terra do interior. Apenas dois eventos vão suplantar este bipartidarismo oriundo das guerras civis que formaram o Uruguai no século XIX: a ditadura militar de 1973-1985 e a ascensão da Frente Ampla - conglomerado de partidos de esquerda que se tornou a principal força política do país quando Tabaré Vázquez, presidente da república entre (2005-2010), foi eleito intendente de Montevidéu. 
de organização ou rearranjo da política habitacional do Uruguai, pois foi permitida a construção de habitações através de dois meios: um primeiro que contava com a ajuda mútua da população demandante, e um segundo que estava relacionado com a economia de poupança. É nesse contexto que temos a criação do Fundo Nacional de Viviendas que é composto pelo Impuesto a la Retribuciones Personales, mas gerido pelo Banco Hipotecário Uruguaio (BHU) e, subordinado ao Ministério da Habitação do Uruguai. Fica a ressalva que a aprovação dessa lei só foi possível porque havia de fundo o atendimento dos interesses de grupos empresariais da construção civil, que estavam interessados em parcerias com o poder público.

Desde 1930, os paradigmas norteadores da política habitacional no Uruguai é marcado pelo "comienzo de la vivienda popular", passando pela intervenção do Estado "en matéria de viviendas de interés social" e pela criação "del Instituto Nacional de Viviendas Económicas", assim como, pela "Ley Nacional de Vivienda y el paso del Estado de bienestar al Estado descretalizado" (Barenboim e Agudelo, 2007). Durante os anos de 1950-1990 o Uruguai, e a América Latina como um todo, vivenciam a crise da dívida externa, o multilateralismo sofre alterações profundas e inicia-se lentamente a abertura comercial do país. Os governos de Julio Maria Sanguinetti Coirolo (1985-1990) e Luis Alberto Lacalle (1990-1995) são cruciais para materializar o processo iniciado anteriormente, pois se formalizaria o projeto de modernização acelerada do Uruguai. Foi sob este contexto que temos em 1991, a criação do "Ministerio de Vivienda, Ordenamiento Territorial y Medio Ambiente" e, que irá alterar profundamente a política de habitação no país. A adoção de uma política habitacional a partir da autogestão e de cooperativas, a partir de 2005, nos governos de Tabaré Vázquez e José Mujica (ambos ligados à Frente Ampla), contribuiu para o fortalecimento do Estado de Bem Estar Social 
no país, assim como foi possível produzir uma ideia de pertencimento, de povo e de nação para aqueles que estiveram à margem desse processo de "modernização" do Uruguai.

A institucionalização da política habitacional foi um elemento importante tanto para as ações dos governos da Frente Ampla, como para o mercado imobiliário. Pois, como nos aponta Cintia Barenboim e Maira Agudelo (2007, p. 176):

[...] la institucionalización del sistema cooperativo que propone la norma es a través dos modalidades de gestión (ayuda mutua y ahorro previo) y dos formas de tenencia (cooperativas de usuarios y de propietarios). La primera forma de tenencia otorga el derecho al uso y goce sobre la vivienda de forma permanente. Es transferible hereditariamente, mientras que la cooperativa, como "empresa", administra la propiedad colectiva. La segunda forma permite que, una vez adjudicada la vivienda, se procese el paso a la propiedad privada y cada asociado se transforme em un deudor individual que responde por si mismo ante el acreedor.

Este contexto modernizador do Uruguai levou uma parcela considerável da população à participação na economia através do cooperativismo, criando assim as condições para o desenvolvimento de Cooperativas de Habitação, e ao mesmo tempo, permitiu que elas fossem utilizadas como um mecanismo de definição das políticas habitacionais no país. Segundo, Eduardo Bavarelli (2006, p. 58), o último recenseamento da entidade que representa nacionalmente as cooperativas uruguaias, a CUDECOOP (Confederación Uruguaya de Entidades Cooperativas), em 1999, havia no Uruguai, com população pouco maior que 3 milhões de pessoas, a impressionante quantia de 844.928 associados em 1.241 cooperativas. Não por acaso, foi possível observar nesse processo a formação de entidades que representem estas cooperativas, a saber: Federación Uruguaya de Cooperativas de Vivienda por Ayuda Mutua (FUCVAM) e a Federación Nacional de Cooperativas de Vivenda (FECOVI). 
Embora o Uruguai esteja em um momento de crescimento econômico e de diminuição de desemprego, as cooperativas e o governo da FA, que se encontra no terceiro mandato consecutivo, no governo federal - Tabaré Vázquez (2005-2010); José Mujica (2010-2015); Tabaré Vázquez (2015-2020) - tem no "novo" Plan Quinquenal de Vivienda o enfrentamento dos atuais desafios habitacionais. Pois, segundo dados do Ministerio de Vivienda, Ordenamieto Territorial y Meio Ambiente (MVOTMA) ${ }^{5}$ o país tem $33 \%$ da população vivendo sem teto ou em precárias condições habitacionais, numa estimativa de 51 mil famílias vivendo em condições precárias de moradia e um total de 42 mil imóveis desocupados em todo país. Além das ações que buscam promover o desmonte da base sindical, o empobrecimento da nova geração de cooperados e a renovação das forças políticas de governo.

A tentativa de ruptura dessa herança é buscada através da organização de movimentos urbanos, sendo suas reivindicações a busca de uma maior atenção do poder público para as questões ligadas ao uso e ocupação do solo, à habitação, ao saneamento básico, ao desmanche entre a cidade oficial e a cidade ilegal etc. Desse modo, a produção e a apropriação do espaço urbano não só refletem as desigualdades e as contradições sociais, como também as reafirma e reproduz. No entanto, o ambiente construído não existe independente das relações sociais e essas imagens cumprem uma função ideológica de abafar o conflito (Maricato, 2000). Uma transformação social que talvez signifique mais do que melhorias urbanas à medida que os benefícios ou sacrifícios se referem ao morador e não às cidades, daí a ideia de que ele tome consciência enquanto o sujeito construtor e desconstrutor do espaço e do lugar da cidade.

Portanto, no estudo buscamos indagar: Que interesses perpassam nas ações feitas (pelo Estado e o mercado imobiliário) na disputa do espaço da cidade? Quais projetos

5 Cf.: http://www.mvotma.gub.uy/. 
os diferentes segmentos da sociedade apresentam para o enfrentamento dos problemas gerados pelo intenso processo de urbanização nas cidades latino-americanas? Quais extorsões o processo espoliativo tem gerado no espaço urbano latino-americano? Teria ele apenas retirado ou deixado de fornecer a um grupo e/ou classe social o que estes consideram como direitos seus? Que tipo de política habitacional reivindicam? Seria esta política portadora de elementos para produção de uma nova sociedade? Do direito à cidade?

\section{Considerações finais}

Esse processo alinhavado a um contexto mundial foi capaz produzir centros urbanos, que junto ao rápido crescimento de sua população e à precariedade dos serviços coletivos, têm afetado de forma contundente o cotidiano daqueles que nela habitam, em particular aqueles de menor poder aquisitivo ou de baixa renda. Dessa maneira, consideramos relevante a discussão sobre as cidades, visto que é sob a população que nela habita que observamos os reflexos das disputas definidas a partir dos instrumentos urbanísticos que organizam o espaço da cidade, materializando assim o seu acesso desigual para uma parcela significativa de sua população, que encontra-se em precários assentamentos, acentuando por sua vez, o processo de segregação socioespacial da cidade.

Desse modo, entendemos que ao invés de minimizar ou solucionar os efeitos da segregação socioespacial, esse processo de acesso desigual do uso e ocupação da cidade apenas beneficiou os interesses do capital imobiliário - ao incentivar a verticalização da cidade, por exemplo, e promovendo a instalação ou implantação de grandes empreendimentos imobiliários tanto no Brasil quanto no Uruguai, o que acabou por "empurrar" a população de baixa renda para áreas 
impróprias de se habitar, à medida que estão desprovidas ou distantes dos bens e serviços coletivos ou públicos, marcando a proliferação de áreas favelizadas, em primeiro lugar, ao redor de áreas próximas ao centro da cidade e de ocupação mais antiga, e em segundo, ao redor dos conjuntos habitacionais populares implantados nos extremos da cidade.

A acelerada urbanização acompanhada da globalização e das crises econômicas coloca-nos diante de processos de desigualdades sociais que se manifesta numa desigualdade do espaço, conforme proposto por Harvey (1980, p. 14;17):

Qualquer teoria geral da cidade deve relacionar à forma espacial que ela assume [...] a única estrutura conceitual adequada para entender a cidade é a que inclui e se edifica ao mesmo tempo sobre as imaginações sociológica e geográfica. Devemos relacionar o comportamento social, de acordo com a geografia e a forma espacial que a cidade assume. Devemos reconhecer que uma vez criada uma forma espacial particular, tende a institucionalizar e, em alguns aspectos, a determinar o futuro desenvolvimento do processo social. Necessitamos, sobretudo, formular conceitos que nos orientem a harmonizar e integrar estratégias capazes de lidar com as complexidades do processo social e os elementos da forma espacial.

Nas cidades, de um modo geral, os processos sociais estão relacionados às formas espaciais, pelo fato de que as contradições sociais do desenvolvimento econômico em conjunto com a produção do espaço urbano - enquanto expressão da divisão territorial do trabalho - e aos instrumentos urbanísticos resultaram em diferenciações socioespaciais que definiram o lugar de vivência de cada um. E como demonstra Harvey (1980, p. 49) a mudança de localização da atividade econômica na cidade significa uma mudança de localização de oportunidades de emprego. Deste modo, a mudança de localização da atividade econômica 
significa mudança de localização de oportunidades de ter acesso aos bens sociais ou coletivos ou públicos, como moradia, transporte, escola, hospitais, entre outros serviços.

Ao observar a política urbana e habitacional de países latino-americano, especificamente, no Brasil e Uruguai, percebemos como a ação do Estado determina o que será feito em termos de infraestrutura, onde e como será o transporte público, onde se localizarão os equipamentos públicos de educação, saúde, entre outros, através de uma gestão essencialmente pública ou mista. Essa ação do Estado como parcelador e empreendedor dá-se de forma diferente, de acordo com os interesses do mercado imobiliário, repetindo processos que se dão ao longo da história do país. $\mathrm{O}$ poder público no Brasil e Uruguai, assim como em outros países do mundo, tem uma lógica de atuação para transformação da cidade que é também a de interesse do mercado. A dificuldade, portanto, da realização preventiva de urbanizações para as populações de baixa renda, cuja rentabilidade não é tão interessante ao mercado produtor de moradia, permanece exigindo subsídios e a presença do Estado como agente do processo de urbanização.

A análise comparativa, portanto, pretende se somar aos esforços dos que acreditam na necessidade de as nações latino-americanas desenvolverem não só seus territórios, mas uma visão própria de sua história, que permita engendrar uma cultura efetivamente própria. Desse modo, indagamos se os Programas de Habitação de Interesse Social, em países da América Latina, deveriam ser considerados uma política de Estado ou apenas uma política de governo? Questão esta de fundamental importância para que as gerações futuras possam definir não só o uso e ocupação do solo urbano, mas também o efetivo acesso ao direito de se viver e habitar na cidade. 


\section{Bibliografia}

Angel, Shlomo. Política de vivienda en Uruguay: diagnóstico y guías de acción (preparado para el Gobierno de Uruguay y el Banco Interamericano de Desarrollo [BID]). Nova York, 2004. Disponível em: <http://sollyangel.com/ wp- content/uploads/2013/10/2004-Housing-Policyin-Uruguay-SPANISH.pdf>. Acesso em: jul. 2016.

Albuquerque, José Augusto. O Futuro do Brasil: A América Latina e o fim da Guerra Fria. Rio de Janeiro: Paz e Terra, 1992.

Arantes, Pedro Fiori; Fix, Mariana. Como o governo Lula pretende resolver o problema da habitação: alguns comentários sobre o pacote habitacional. Correio da Cidadania (01 ago. 2009). Disponível em: $<w w w . c o r r e i o c i d a d a n i a . c o m . b r>$. Acesso em: ago. 2013.

Arantes, Otília; Vainer, Carlos; Maricato, Ermínia. A Cidade do Pensamento Único: Desmanchando consensos. Petrópolis: Vozes, 2000.

Arrethe, Marta (org.). Trajetórias das desigualdades: como o Brasil mudou nos últimos cinquenta anos. São Paulo: Editora UNESP, 2015.

Barenboim, Cintia; Agudelo, María. Evolución de las políticas habitacionales en Uruguay (periodo 1870-2000). Disponível em: http:<//www.javeriana.edu.co/viviendayurbanismo/pdfs/CVU_V3_N6-01.pdf>. Acesso em: jul. 2016.

Baravelli, José Eduardo. O cooperativismo uruguaio na habitação social de São Paulo: das cooperativas FUCVAM à Associação de Moradia Unidos de Vila Nova Cachoeirinha. Dissertação de Mestrado, FAU/USP, São Paulo, 2006.

Boito Junior, Armando. Estado, politica e classes sociais: ensaios teóricos e históricos. São Paulo: UNESP, 2007.

Bonduki, Nabil. Origens da habitação social no Brasil: Arquitetura moderna, Lei do Inquilinato e difusão da casa própria. São Paulo: Estação Liberdade: FAPESP, 1998. 
Borón, Atílio. A América para os norte-americanos. Revista Fórum, $\mathrm{N}^{\circ}$ 10, 2003.

Borón, Atílio; Kouy, Ana Paula. Os pioneiros da habitação social no Brasil. São Paulo: Editora do SESC; Editora da UNESP, 2014.

Cano, Wilson. Soberania e Política Econômica na América Latina. São Paulo: UNESP, 2000.

Castro, Maria Silva Porrella de. Uruguai: Coleção Nossa América Nuestra. São Paulo: Editora Fundação Perseu Abramo, 2016.

Cardoso, Adauto Lúcio (org.). O programa Minha Casa Minha Vida e seus efeitos territoriais. Rio de Janeiro: Letra Capital, 2013.

Cardoso, Fernando Henrique; Faletto, Enzo. Dependência e desenvolvimento na América Latina: Ensaios de interpretação sociológicos. Rio de Janeiro, Zahar Editores, 1977.

Cruz, Antônio. A dinâmica da economia solidária. In: $A$ diferença da igualdade: a dinâmica da economia solidária em quatro cidades do Mercosul. Tese de Doutorado, UNICAMP. Disponível em: <http://www.unicamp.br/unicamp>. Acesso em: out. 2006.

Denaldi, Rosana (org.). Planejamento Habitacional: notas sobre a precariedade e terra nos Planos Locais de Habitação. São Paulo: Annablume, 2013.

Dowbor, Lasdislau (Org.). Desafios da Globalização. Petrópolis: Vozes, 1997.

Fernandes, Florestan. Capitalismo Dependente e Classes Sociais na América Latina. Rio de Janeiro: ZAHAR, 1973.

Fiori, José Luis (Org.). Estados e moedas no desenvolvimento das nações. Petrópolis: Vozes, 1999.

Furtado, Celso. O Capitalismo Global. Rio de Janeiro: SNEL, 1998.

Galeano, Eduardo. As veias abertas da América Latina. Rio de Janeiro: Paz e Terra, 2007. 
Giaudrone, Carla. Deseo y modernización: el modernismo canônico esteticista en el fin de siglo uruguayo. In: Achugar, Hugo; Moraña, Mabel (coords.). Uruguay: imaginários culturales: Desde las hullas indígenas a la modernidad. Montevidéu: Ediciones Trilce, 2000.

Harvey, David. A justiça social e a cidade. São Paulo: Hucitec, 1980.

Harvey, David. A crise mundial é uma crise da urbanização. Disponível em:<http://www.forumreformaurbana.org.br/_ reforma>. Acesso em: fev. 2010.

Harvey, David. O direito à cidade. Revista Piauí. São Paulo: Ed. Abril, No 82, jul. 2013.

Ianni, Octávio. Imperialismo na América Latina. Rio de Janeiro: Civilização Brasileira, 1997.

Jacob, Olaf (Org.). Pobreza, desigualdad de oportunidades y políticas públicas en América Latina. Rio de Janeiro: Konrad-Adenauer-Stiftung, 2012. Disponível em: $<$ http://www.kas.de/wf/doc/kas_32590-1522-1-30.pdf? 121121125019>. Acesso em: jul. 2016.

Júnior, Caio Prado. História econômica do Brasil. São Paulo: Brasiliense, 1980.

Kowarick, Lúcio. A espoliação urbana. Rio de Janeiro: Paz e Terra, 1979.

Kowarick, Lúcio. Escritos Urbanos. São Paulo: Ed. 34, 2000. Lago, Luciana Corrêa do. Autogestão habitacional no Brasil: utopias e contradições. Rio de Janeiro: Letra Capital: Observatório das Metrópoles, 2012.

Maricato, Ermínia. A produção capitalista da casa (e da cidade) no Brasil industrial. São Paulo: Alfa-Omega, 1982.

Maricato, Ermínia. Brasil 2000: qual planejamento urbano? Cadernos IPPUR, Rio de Janeiro, ano XI, $\mathrm{N}^{\circ} 1$ e 2, pp. 113-130, 1997.

Maricato, Ermínia. O "Minha Casa" é um avanço, mas segregação urbana fica intocada. Entrevista concedida à Agência Carta Maior. Disponível 
em: <http://www.cartamaior.com.br/templates/materialMostrar.cfm?materia_id=16004>. Acesso em: jan. 2013.

Ministerio De Desarrolo Social (MIDES). Vulnerabilidad y exclusión: Aportes para las politicas sociales, 2005. Disponível em: <http://www.mides.gub.uy/innovaportal/ file/22972/1/uruguay_social_vol5.pdf>. Acesso em: jul. 2016.

Moisés, José Álvaro. Cidade, Povo e Poder. Rio de Janeiro: Paz e Terra, 1985.

Moreira, Constanza. A esquerda no Uruguai e no Brasil: cultura política e desenvolvimento partidário. Campinas: Scielo, vol. 6, $\mathrm{N}^{\circ} 1,2000$.

Navarrete, Rubén Darío. Autogestão das cooperativas de habitação de interesse social: os modelos solidários como alternativa de produção de moradias e desenvolvimento social. Dissertação de Mestrado, Universidade Católica de Pelotas, Pelotas, 2008.

Prado, Maria Lígia. A Formação das Nações LatinoAmericanas: anticolonialismo, anti-imperialismo: constituição das oligarquias: A América é livre? Campinas: Unicamp, 1986.

Ribeiro, Ana Clara Torres (Comp.). O Rostro Urbano da América Latina. Buenos Aires: Consejo Latinoamericano de Ciências Sociales: CLASCO, 2004.

Rolnik, Raquel. O que é cidade. São Paulo: Brasiliense, 1994.

-- (Org.). Como produzir moradia bem localizada com recursos do programa Minha Casa, Minha Vida: implementando os instrumentos do Estatuto da Cidade. Brasília: Ministério das Cidades, 2010.

Rolnik, Raquel. Brasil: conflitos por moradia estão aumentando no Brasil. Jornal Le Monde Diplomatique Brasil (02 fev. 2012). Disponível em: <http://diplomatique.org.br/ conflitos-por-moradia-estao-aumentando-nobrasil/>. Acesso em: jul. 2016.

Rolnik, Raquel. Guerra dos lugares. São Paulo: Boitempo, 2015. 
Romero, José Luis. América Latina: as cidades e as ideias. Rio de Janeiro: Editora UFRJ, 2004.

Saes, Décio. República do capital. São Paulo: Boitempo, 2001. Santos, Elisângela da Silva. A nação escrita entre a prática e o ideal: os projetos de Monteiro Lobato e José Enrique Rodó. Tese de Doutorado, FFC/UNESP, Marília, 2003.

Santos, Milton. A urbanização brasileira. São Paulo: Hucitec, 1993.

Silva, Luís Inácio Lula da. Discurso do Presidente da República do Brasil na 59० Assembleia da ONU. Nova York, EUA. Disponível em: <http://www.mre.gov.br/>. Acesso em: nov. 2004.

Singer, André. Os sentidos do lulismo: reforma gradual e pacto conservador. São Paulo: Companhia das Letras, 2012.

Vaz, Ana Luiza, de Lyra. Mutirão Habitacional Autogestionário: experiência do Centro de Assessoria à Autogestão Popular Grande São Paulo: 1980-1990. Dissertação de Mestrado, PUC/SP, São Paulo, 2000.

Vasconcellos, Marco Antônio. Descripción sintética y elementos para una evaluación de la experiencia del cooperativismo de Viviendas por Ayuda Mutua y de otras formas asociativas en el Uruguay (1965-1982). São Paulo: Atlas, 2004.

Viotti, Emília. O que é e para onde vai a América Latina? Margem esquerda: ensaios marxistas, $\mathrm{N}^{\circ}$ 9, 2007. 

II. Mercado inmobiliario, segregación y gentrificación 



\title{
A reprodução dos padrões de segregação residencial en Salvador (Brasil)
}

\author{
Uma análise crítica das intervenções \\ habitacionais do Estado ao exemplo \\ de novos alagados
}

\author{
StePHAN TREUKE
}

\section{Resumo}

Neste trabalho, examinam-se os processos de segregação residencial no quadro da organização socioespacial de Salvador. Em um primeiro momento, a dinâmica de expansão da cidade deve ser compreendida a partir dos processos da industrialização, iniciada pela Petrobras em 1954 que atraiu um desproporcionado afluxo de migrantes procedentes do interior do Estado ocupando as regiões periféricas da cidade com precárias condições de habitação e infraestrutura. Com o fim do padrão desenvolvimentista e o deslocamento dos investimentos para o Sudeste, instalamse na década de 90 mecanismos de reestruturação produtiva de cunho neoliberalista que se traduzem na crescente terceirização e flexibilização das relações de trabalho, engrossando o já expressivo contingente da classe do subproletariado excluído do mercado imobiliário formal. Em um segundo momento, a assimétrica distribuição socioespacial da cidade pode ser visualizada como resultado da atuação hegemônica de grupos imobiliários em aliança com 
as políticas urbanas, produzindo uma engrenagem segregadora obediente à lógica mercantilista de valorização fundiária por meio dos dispositivos de planejamento urbano, da provisão de infraestrutura, dos programas públicos de habitação e da criação de empregos. Globalmente, a distribuição espacial de Salvador correlata com a repartição de renda da sua população, consolidando a configuração de três vetores de expansão: a Orla Atlântica Norte, o Subúrbio Ferroviário e o Miolo Urbano. Esboçam-se tendências de dualização à escala macrourbana no município-sede que se perpetuam na sua região metropolitana à base de significantes discrepâncias entre o que pode ser visualizado esquematicamente como a "cidade formal" - (Orla Atlântica Norte) dominada por áreas altamente valorizadas dos grupos médio-superiores, dotadas de ampla infraestrutura e de oportunidades empregatícias - e, por outro lado, a "cidade informal" (Subúrbio Ferroviário e Miolo Urbano) - marcada por invasões sucessivas, loteamentos populares e conjuntos habitacionais ocupados majoritariamente pelo segmento popular (inferior), com atrofia em ofertas de emprego e de investimentos estatais em infraestrutura e bens públicos. A exemplo de Novos Alagados, complexo de palafitas localizado no Subúrbio Ferroviário, serão criticamente examinadas as intervenções habitacionais implementadas pelo governo estadual entre 1990 e 2005. O estudo ressalta a responsabilidade das políticas urbanas na consolidação de mecanismos de segregação ao perpetuar situações de pobreza resilientes no tempo que prejudicam a integração socioeconômica de seus moradores, inseridos em contextos residenciais de forte homogeneidade social. A sua limitação à recuperação físico-urbanística do habitat, desvinculada de investimentos flanqueadores em equipamentos urbanos e infraestrutura (emprego, saúde, segurança, educação), remete pelo caráter paliativo-minimalista das intervenções que "programam" o confinamento da classe baixa em áreas isoladas, logo abandonadas pelo poder público. O corrosivo efeito de externalidades negativas, como altas taxas de 
desemprego e de pobreza, é potenciado em áreas desassistidas, bloqueando a mobilidade econômica e arriscandose a tornar o local socialmente invisível e territorialmente estigmatizado já que desvinculado dos outros estratos sociais da cidade.

\section{Palavras-chave}

Segregação Residencial; Políticas Urbanas; Novos Alagados.

\section{Introdução}

A relevância da dimensão territorial como fator de reprodução da pobreza já foi largamente discutida nos Estados Unidos. A polarização da sociedade a partir de critérios raciais e, crescentemente, econômicos coaduna com uma elevada divisão espacial em virtude da hegemonia de princípios mercantológicos e de práticas racialmente discriminatórias inerentes ao mercado imobiliário, e do baixo grau de intervenção do Estado no planejamento urbano e no setor da habitação social. Este cenário se confirma também pelo caso brasileiro, ressalvando-se que os padrões de segregação residencial obedecem preponderantemente a critérios econômicos.

No Brasil, a reprodução das desigualdades socioeconômicas dentro do modo de produção do capitalismo periférico já foi amplamente discutida no bojo das teorias de modernização e de marginalidade desde o final da década de 1940, porém sem que estas reflexões tivessem incitado à elaboração de políticas de combate às desigualdades sociais.

Prevaleceu a tácita tolerância de uma "massa marginal" (NUN, 1969) como elemento ora dissociado ora aleatoriamente ou precariamente inserido no sistema econômico e na sociedade que, de uma forma ou outra, tinha que desenvolver estratégias de sobrevivência sem poder contar com uma intervenção do Estado através de políticas 
de distribuição de renda, abstraindo-se o favoritismo clientelista que gradativamente promoveu melhorias em termos de investimentos em infraestrutura e equipamento nas regiões periféricas menos integradas.

A política de tolerância permitia a invasão das regiões periféricas no período pós-guerra que, no entanto, ocorreu através da difusão de práticas ilegais e improvisadas de autoempreendimento cujo resultado foi a institucionalização de dois sistemas de acesso ao mercado habitacional.

A recente transição para o regime socioprodutivo pósfordista tem impulsionado a retomada da questão sobre a pobreza, visualizada doravante como um processo dinâmico que não é mais amortizado pela expansão do setor manufatureiro e industrial e pela difusão de um padrão de consumo de massa.

Desde a década de 1980, as políticas públicas se deslocaram de um tácito laissez-faire para estratégias mais intervencionistas, implicando na remoção das slums localizados em áreas urbanas valorizadas, na consolidação de assentamentos informais através do investimento em infraestrutura e equipamento urbano e da regularização do seu título de posse. Entretanto, a construção de conjuntos habitacionais nas regiões limítrofes das metrópoles para as camadas (média) baixas largamente reproduz os padrões de segregação residencial anteriores.

Abstraindo-se destas intervenções do Estado que, na sua maioria, não proporcionavam maiores estruturas de oportunidades in situ para sua população nem seguiam estratégias de dessegregação, a desregularização da economia e do mercado imobiliário na década de 1980 reforçou a hegemonia dos interesses privados na organização socioespacial.

Esta repercute em processos de gentrificação nas áreas centrais e na proliferação de condomínios privados, produzindo novas constelações de proximidade geográfica entre classes socialmente distantes particularmente nas regiões periféricas das metrópoles. 
Em Salvador, a histórica e geograficamente constituída cisão entre Cidade Alta e Cidade Baixa se transformou em um arranjo mais heterogêneo, comportando ambos os elementos do tradicional dualismo centro/ periferia e descontinuidades espaciais denotando um maior grau de fragmentação a escala microurbana, conquanto vigenciem os mesmos mecanismos estruturantes de apropriação desigual do espaço conforme critérios econômicos.

Constitui objetivo deste trabalho discutir estes processos de segregação ocorrendo ao nível macrourbano da cidade-município, correlatando seus desdobramentos territoriais com a industrialização iniciada na década de 1950 e com a progressiva polarização espacial cimentada por um mercado imobiliário altamente segregador que atua em concomitância com as políticas urbanas neoliberais.

Neste sentido, a segunda seção providencia a fundamentação teórica sobre a segregação urbana para examinar, na terceira seção, o arranjo da diferenciada apropriação do espaço urbano pelas classes sociais em Salvador, base da classificação trivetorial entre Orla Marítima Norte, Subúrbio Ferroviário e "Miolo Urbano". Já a quarta seção focaliza os mecanismos reprodutores da segregação à escala microurbana, a exemplo de Novos Alagados, à luz das estratégias habitacionais implementadas pelo governo entre 1970 e 2005 e destaca a responsabilidade do Estado na consolidação de um padrão de conformação espacial excludente que favorece a concentração involuntária de populações de baixo poder aquisitivo em áreas periféricas desassistidas com baixo grau de integração socioeconômica. 


\section{Breves reflexões acerca da abordagem da pobreza e segregação na Sociologia Urbana}

Estudos empíricos indagando sobre os padrões de distribuição dos grupos sociais no espaço remontam às reflexões seminais da Escola de Chicago, destacando-se as contribuições de Robert E. Park (1987 [1915]). A segregação de determinados grupos sociais relativamente homogêneos nas áreas centrais das cidades norte-americanas baseando-se em critérios étnico-raciais e socioculturais era interpretada como um fenômeno "natural" e essencialmente transitório já que figurava apenas como o estágio inicial de adaptação ao meio urbano dentro de um processo de mobilidade residencial mais complexo (Park, Burgess e Mckenzie, 1925).

Em um segundo momento, as premissas teóricas da Ecologia Social foram criticados pela vertente neomarxista da Economia Política emergindo no final da década de 1960.

Sob a esta ótica, a cidade não era mais visualizada como mero receptáculo ou unidade espacial dissociada de processos macrossociais e macroeconômicas mas como espaço socialmente (re)produzido que refletia a luta de classes sociais e a hegemonia do mercado imobiliário capitalista consolidada pela atuação do Estado através das políticas urbanas (Gottdiener e Feagin, 1988; Harvey, 1980; Logan e Molotch, 1987).

Desde a década de 1990, discute-se controvertidamente o conceito de global cities (Sassen, 1991) e particularmente a relevância da hipótese de uma estreita correlação entre a agudização das disparidades nas dois polos extremos da estratificação social e polarização socioespacial.

Não obstante a rápida difusão e popularidade desta hipótese, uma série de contraevidências foram apresentadas através de estudos conduzidos em distintas metrópoles de menor porte que buscavam correlacionar as transformações na estrutura do mercado de trabalho com a reconfiguração da organização socioespacial de distintas metrópoles. 
Em quintessência, estas convergem em apontar pela necessidade de levar em consideração as múltiplas contingências e a trajetória histórica dentro do desenvolvimento de cada metrópole (Beauregard e Haila, 2000; Marcuse e Van Kempen, 2000).

No Brasil, convém distinguir duas tradições intelectuais que influenciaram substancialmente os estudos sobre a marginalidade e a pobreza urbana: uma vertente funcionalista-estruturalista assentada em um enfoque econômico, e outra vertente sociocultural alinhada à corrente da ecologia urbana e centrada no conceito de culture of poverty.

Dentro do panorama das reflexões gravitando em torno do conceito de marginalidade a partir do enfoque econômico convém destacar, em primeiro lugar, a teoria de modernização. Conforme esta teoria, a América Latina estava experimentando um processo de transição para uma sociedade industrial e essencialmente urbana que se manifestava na coexistência funcional de um segmento integrado no mercado de trabalho formal e um grande contingente populacional formalmente excluído das estruturas do mercado laboral e imobiliário.

Em segundo lugar, uma série de autores recuperaram os postulados teóricos de Karl Marx acerca das contradições inerentes ao modo de produção capitalista e da emergência de um "exército de reserva industrial" ou de "superpopulação relativa” (Kowarick, 1975).

Os principais exponentes desta proposta postulavam que a marginalidade não constituía um problema per se pela integração econômica na sociedade capitalista, refutando a hipótese do dualismo estrutural da sociedade (Cardoso e Faletto, 1970; Kowarick, 1975). Seguindo esta linha de argumentação, os pobres estavam integrados no circuito de produção capitalista, ainda que de modo precário, aleatório e marginal. 
Conforme a leitura culturalista da pobreza à luz do conceito de marginalidade, os grupos de imigrantes procedentes das áreas rurais pauperizadas do Brasil encontravam sérios obstáculos de adaptação ao meio urbano e de integração no circuito da produção capitalista, dada a persistência de um sistema de valores pautado na vida agrária pré-capitalista.

Uma das questões urbanas mais discutidas remetia à dualidade favela e cidade, o que impulsionou a realização de uma série de estudos nas décadas de 1940 e 1950 que adotaram um recorte racionalista, higienista ou sanitário e propunham uma visão moralista dos aglomerados populares. Esta visão posteriormente legitimou a execução dos programas de erradicação das favelas localizadas nas regiões centrais da cidade.

Em analogia ao contexto estadunidense dos anos 1960, surgiram vozes críticas procurando demostrar empiricamente o alto grau de organização social-institucional nas "slums", favelas etc. que desafiavam as hipóteses de Lewis (Lomnitz, 1975; Perlman, 1976).

Estes autores enfatizavam que existia um ativo engajamento político deste contingente populacional pelo viés de movimentos sociais e comunitários, uma majoritária adesão aos modelos de ascensão social norteada na sociedade mainstream assim como uma forte articulação social e política a partir de redes clientelistas.

Posteriormente à abordagem da marginalidade, ganhou relevância na discussão acadêmica sobre a reprodução das desigualdades sociais desde a década de 1970 uma aproximação (neo)marxista à pobreza urbana que correlacionava as expressivas estruturas de segregação residencial econômica com as contradições inerentes ao modo de produção capitalista e com a intervenção do Estado no planejamento urbano.

Dando continuidade à trajetória da abordagem da questão social no Brasil, convém assinalar para uma série de evoluções macropolíticas e socioeconômicas, nomeada- 
mente o processo de redemocratização, a reestruturação da economia e o subsequente declínio do modelo de substituição das importações, que no âmbito acadêmico induziu a um gradativo distanciamento do enfoque estruturalista.

Os estudos pleiteiam pela integração de diferentes atores em modelos explicativos sobre a (re)produção da nova pobreza urbana, como os (novos) movimentos sociais, a comunidade e as próprias famílias moradores de bairros pobres (Castells, 1983).

Concomitantemente, produziu-se um deslocamento do centro de gravitação dos estudos urbanos que, em vez de identificar as principais causas estruturais da segregação residencial econômica, começaram a priorizar a análise das suas múltiplas repercussões no bem-estar e no desempenho socioeconômico do indivíduo.

\section{Processos de segregação residencial em Salvador da Bahia}

A cidade de Salvador foi fundada em 1549, abrigando as principais funções político-administrativas e mercantis do país até a transferência da capital para o Rio de Janeiro ainda no período colonial em 1763. Sua economia estava centrada no ramo agrário-mercantil, voltada para o mercado internacional e assentada na base agroindustrial-açucareira e fumageira, ambas localizadas no circunferente Recôncavo Baiano.

Desde a perda da sua função de capital, a cidade experimentou um longo processo de estagnação econômica e populacional, fazendo emergir uma estrutura de mercado de trabalho assentada na prestação de serviços pessoais, no artesanato, na burocracia estatal, na construção civil e no pequeno comércio, com uma reduzida oferta de postos de qualidade em comparação com os centros mais dinâmicos do Sudeste. 
A cidade apenas voltou a crescer em termos espaciais e demográficos na década de 1950, dinâmica impulsionada pela instalação da Petrobras no Recôncavo da Bahia. O maior alavancamento pela indústria se deu a partir da implementação das políticas nacionais de desenvolvimento regional viabilizando a construção do Centro Industrial de Aratú (CIA) na segunda metade da década de 1960 e do Complexo Petroquímico de Camaçari (COPEC) na década de 1970.

Mesmo que esta indústria tivesse vínculos relativamente reduzidos com os demais setores da economia regional e estadual, seus investimentos estimularam a emergência de uma ampla gama de novas atividades vinculadas ao ramo da indústria petrolífero-química enquanto produziram a modernização de outras funções estratégicas, beneficiando sobremaneira o varejo local, a implementação de supermercados e shopping centers, e os serviços de consumo intermediário ou final.

Os empregos vinculados à indústria de transformação se expandiram nomeadamente a partir da implementação do Complexo Petroquímico de Camaçari. Esta dinâmica contribuiu à emergência de um operariado industrial moderno, com qualificação, salários e benefícios superando em muito a média local. Um importante papel na "modernização" da cidade incumbia à construção civil, criando postos de trabalho no setor profissional não-qualificado. Tanto a demanda das empresas da indústria quanto a expansão da massa salarial e da renda estenderam significantemente as oportunidades para a prestação de serviços.

$\mathrm{O}$ processo de industrialização da cidade que ocorreu principalmente a partir da implementação da Petrobras e da COPEC/CIA incidiram sobre uma configuração populacional caraterizada pela grande oferta de mão de obra de baixa qualificação, cenário ainda agravado pelos grandes fluxos de imigrantes procedentes do hinterland da Bahia, e pela vinculação de uma grande parcela da mão de obra a ocupações precárias e de baixa remuneração. 
Desta forma, mesmo no seu auge de crescimento econômico nas décadas de 1970 e 1980, quando o ramo industrial da capital baiana se destacou por ser uma das metrópoles mais dinâmicos do país, persistiram os problemas ocupacionais estruturais e a pobreza de amplos segmentos da população.

Acompanhando o processo de expansão territorial e de modernização da cidade nas décadas de 1960 e 1970, uma intensa ocupação informal por parte das famílias de baixa renda nas regiões periféricas da cidade pôde ser observada enquanto foram introduzidos os primeiros planos diretores para regular a dinâmica de crescimento espacial da cidade.

Este processo de ocupação das classes baixas ocorreu principalmente a partir de "invasões", denominação comumente atribuída às áreas de habitação popular que se constituíram por ocupação espontânea, direta e coletiva, e à revelia dos proprietários fundiários (GORDILHO-SOUZA, 2001).

Nesta fase de rápida urbanização da cidade, a invasão espontânea representava uma prática comum, e mesmo incentivada por alguns proprietários de terras desocupadas na periferia urbana, até então pouco valorizadas.

A expressiva tendência de adensamento demográfico e expansão territorial pelo viés deste padrão de ocupação informal também deve ser imputada à dificuldade de exploração formal das regiões internas dos vales, respetivamente das áreas de alta declividade que não correspondiam às regiões de interesse das empresas imobiliárias da época.

Portanto, durante as primeiras décadas pós-guerra, estas áreas permaneciam praticamente fora do mercado imobiliário formal. Convém ressaltar que as ocupações espontâneas não se restringiam às regiões mais distantes do centro, mas incluíam as áreas relativamente próximas ao centro, inseridas em vales e charcos onde surgiam os primeiros bairros pobres de Salvador. 
Não obstante, esta permissividade da invasão como modelo informal de ocupação das terras vazias pelas camadas baixas se alterou profundamente à medida que aumentava o fluxo de imigrantes e incrementava a demanda habitacional tanto das camadas baixas como das camadas média-altas. Um dos momentos cruciais foi a implementação da Lei da Reforma Urbana (1968) que transferia as propriedades antigamente controladas pelo regime de enfiteuse para o Estado que alienou as regiões para um número muito reduzido de proprietários privados.

Impulsionado pelo processo de industrialização, este aumento da demanda incentivou a exploração privada das áreas vazias da cidade seguindo as estratégias de especulação fundiária.

Esta estratégia de retenção ou bloqueio artificial de vastas áreas da cidade por proprietários privados também se fundamentava na esperança de logo ser favorecido por investimentos em infraestrutura e equipamento urbano à medida que a cidade iria se expandir geograficamente, provocando um processo de escassez deliberada de áreas disponíveis que dificultava a inserção habitacional das camadas mais baixas na cidade.

Como resultado deste processo e dada a insuficiência de renda destas camadas de comprar terrenos, multiplicaram-se as ocupações coletivas por "invasão" por famílias sem recursos e sem moradia, à revelia do proprietário fundiário, portanto, sem consentimento, intermediação ou comercialização (Gordilho-Souza, 2001).

No bojo das grandes imigrações, multiplicaram-se as tentativas de ocupação espontânea como a Liberdade, Alagados e Nordeste de Amaralina. Conforme Gordilho-Souza (2001), no início dos anos 1990, em Salvador, as invasões totalizavam $14 \%$ das áreas ocupadas por habitação.

A estas áreas se somam as outras áreas de ocupação informal, totalizando $32 \%$ da ocupação habitacional. As construções de casa, nomeadamente no caso de Novos Alagados onde ocorreu em cima da maré, apresentavam graves 
deficiências habitacionais e infraestruturais, e refletiam o baixo poder de compra e a persistência da ausência de políticas de moradia do governo.

Durante o período da ditadura militar, grande parte destas invasões foi erradicada pelo Estado, particularmente nas regiões litorâneas aonde havia um conflito de interesse com as grandes empresas imobiliárias, sendo que sua população na maioria foi relocada para as áreas localizadas nas zonas limítrofes da cidade.

As políticas de remoção e de expulsão contribuíram a consolidar os processos de segregação residencial obediente ao gradiente centro-periferia e converteram as regiões socialmente mais heterogêneas em bairros com predomínio das classes média e alta.

Ao mesmo tempo que crescia a demanda habitacional no bojo da industrialização, assiste-se a um processo de maior formalização de políticas urbanas que iriam doravante impregnar seu caráter dentro do planejamento urbano.

A partir das décadas de 1960/1970, a suburbanização e posterior metropolização do município foi incentivada nomeadamente pela abertura das primeiras grandes "avenidas de vale" nos anos 1960/1970 e com o deslocamento do centro administrativo-econômico para o vetor norte Iguatemi-Tancredo Neves-Av. Luis Viana Filho (doravante Av. Paralela) que abriga o novo Centro Administrativo da Bahia (CAB).

$\mathrm{Na}$ década de 1980, consolidou-se um novo centro urbano, impulsionado por empreendimentos públicos e privados realizados na década anterior, com destaque para a constituição da chamada Avenida Paralela, do Centro Administrativo da Bahia, da nova Estação Rodoviária e do Shopping Iguatemi.

Em grandes linhas, a distribuição espacial de Salvador correlata com a repartição de renda da sua população, consolidando a configuração de três vetores de expansão: a Orla Atlântica Norte, o Subúrbio Ferroviário e o 
"Miolo Urbano" com eminentemente diferenciados acessos ao mercado de trabalho, à moradia, à infraestrutura e às benfeitorias dos serviços públicos.

A Orla Atlântica Norte, totalizando $44 \%$ da superfície da cidade, beneficiou-se da implementação de modernos centros comerciais-financeiros, equipamentos urbanos e universidades privadas, aglomerando uma ampla gama de oportunidades de emprego nos eixos Pituba-Costa Azul e Boca do Rio-Patamares.

O surgimento deste novo e dinâmico centro econômico incentivou a instalação dos segmentos superior e médiosuperior (técnicos e profissionais de qualificação superior, como administradores, economistas, engenheiros, contadores, advogados, professores e profissionais de saúde), se rebatendo na proliferação de condomínios verticais nos espaços intermediários entre a litorânea Av. Octávio Mangabeira e a Av. Paralela ao expulsar a sua antiga população de baixa renda para as áreas remotas do "Miolo Urbano" e do Subúrbio Ferroviário.

Um adensamento habitacional de forma verticalizada se produziu gradativamente também nos bairros do centro tradicional do tipo médio(-superior) já altamente valorizados, que totalizam a maior oferta de empregos, acrescentando-se a estes as áreas "abastecidas" consolidadas que margeiam a Orla Atlântica Sul como Barra, Ondina e Rio Vermelho. A cidade tradicional abriga predominantemente a função residencial e de pequeno comércio, formado por domicílios da classe média em edificações antigas que se alinham a uma mancha ocupada compacta e contínua.

Já no Subúrbio Ferroviário, localizado no sudoeste da capital baiana e correspondendo a $12,5 \%$ da superfície total de Salvador com aproximadamente 500 mil habitantes espalhados por 22 bairros, predomina a informalidade em termos urbanísticos e a omissão de investimentos públicos. 
A região teve sua ocupação impulsionada pela implantação da linha férrea da Leste Brasileira, em 1860, constituindo, a partir da década de 1940, o vetor estruturante de loteamentos populares que foram gradativamente ocupados nas décadas seguintes pelos segmentos popular (com predominância de trabalhadores manuais da indústria e do comércio, e prestadores de serviços com alguma qualificação) e popular-inferior (trabalhadores prestadores de serviços não qualificados, trabalhadores domésticos, ambulantes e biscateiros) em forma de invasões (Carvalho e Pereira, 2014).

Nos anos 1960 e 1970, a região passou por um processo de adensamento e espraiamento, atraindo grandes contingentes de pessoas pobres procedentes de migrações campocidade em função da implantação da indústria petrolífera e siderúrgica nas regiões periurbanas. $\mathrm{O}$ afluxo demográfico se traduziu na multiplicação de arranjos habitacionais de padrão autoconstrução como será demostrado no caso de Novos Alagados.

O terceiro vetor de expansão em apreço engloba o espaço intersticial no centro geográfico do município entre a BR-324 e a Av. Paralela, limitado no norte pela Represa do Ipitanga, característica topográfica que lhe conferiu a denominação de "Miolo Urbano". Ele se estende por cerca de 11.500 ha. e reúne 41 bairros, correspondendo aproximadamente a $35 \%$ da superfície da cidade. $\mathrm{O}$ acidentado terreno de antigas fazendas desapropriadas por decreto em 1975 abriga mais de 30\% da população total soteropolitana com predominância das tipologias socioespaciais média e popular (Carvalho e Pereira, 2014).

A exploração deste novo vetor de expansão territorial foi promovida pelas políticas de habitação implementadas na década de 1960 e desenhadas para as famílias com rendimento mensal de entre 3-5 salários mínimos, enquanto as áreas adjacentes foram ocupadas irregularmente por invasões. 
$\mathrm{Na}$ contemporaneidade, a área constitui o principal eixo do crescimento demográfico aonde coexistem conjuntos habitacionais, loteamentos regulares e moradias precárias. A região acusa deficiências de infraestrutura e de acesso a serviços públicos conquanto abriga um diversificado comércio de porte local. Recentemente, foi contemplada por vários projetos de integração viária nos seus eixos estratégicos (BR-324 e Av. Paralela).

Nas últimas duas décadas, uma série de transformações tem impactado na organização socioespacial da cidade sem, no entanto, alterar profundamente o padrão de organização socioespacial centro-periferia.

Observa-se a escala microurbana um maior grau de fragmentação do tecido urbano, conferindo à distribuição socioespacial um caráter mais heterogêneo. A contiguidade geográfica entre condomínios habitados pelos segmentos médio-superior e resistências de invasões que foram se consolidando em bairros segregados com alta densidade demográfica onde prevalece a categoria popular(-inferior) diverge do padrão homogêneo de apropriação espacial da Orla Atlântica Norte.

Em analogia, a implantação de condomínios para a classe média em áreas periféricas menos valorizadas rompe com a continuidade da mancha urbana do "Miolo Urbano".

\section{A intervenção urbana no caso de Novos Alagados}

O crescimento demográfico da invasão de Novos Alagados (Subúrbio Ferroviário), surgido nos anos 1970, coincide com a implantação da Av. Suburbana e a instalação do Centro Industrial de Aratu em 1968 na Região Metropolitana de Salvador, atraindo tanto populações pobres desapropriadas no trecho viário da citada avenida quanto moradores dos antigos Alagados e de outros bairros da cidade. 
Seu rápido adensamento em forma ora de palafitas erguidas em cima da maré na Enseada dos Tainheiros/ Cabrito, ora de casebres de madeira semiconsolidados em terra firme e nas bordas de manguezais, se produziu em completa ausência de fiscalização urbanísticoambiental do poder público que estava ainda concentrando seus esforços na recuperação da invasão vizinha, Alagados.

Em um contexto de redemocratização do país com forte atuação de movimentos populares pressionando intervenções públicas dos governos locais para remediar o déficit habitacional e atender às demandas populares de consolidação e urbanização das áreas precárias, o local foi gradativamente incorporado em projetos de requalificação físico-ambiental implicando no "transplante" das aproximadamente 12.000 pessoas em conjuntos habitacionais.

Abrangendo o período entre 1990 e 2005, o projeto orçamentado pelo $\mathrm{BNH}$ e, posteriormente, pela cooperação entre o Banco Mundial, a Associação Voluntários para o Serviço Internacional e a Companhia de Desenvolvimento e Urbano do Estado da Bahia, previa uma ampla participação comunitária no processo de reassentamento e a promoção do desenvolvimento local através de investimento em infraestrutura e equipamento urbano.

Pese aos avanços alcançados em questões habitacionais, as intervenções não contemplavam a construção de estruturas socialmente integradoras que pudessem alavancar a mobilidade econômica da sua população e contribuir à desestigmatização do local. O "transplante" do ambiente aquático à terra firme em forma de embriões monofuncionais, que logo apresentavam sinais de deterioração, subjugado a uma visão tecnocrática de combate à pobreza, não logrou romper o ciclo vicioso da segregação da área. 
A resiliência das estruturas de pobreza decorre da omissão em investimentos em setores transversais (educação, saúde, emprego). A ausência do poder público se revela também na degradação físico-ambiental da área e na descontrolada atuação de frações rivais disputando o tráfico de drogas no bairro, contribuindo à erosão da base de confiança na vizinhança e na decadência da organização comunitária, que providenciava antigamente solidariedade e coesão social.

A maioria dos habitantes continua sofrendo a precariedade das condições de moradia, saúde e segurança, situação sombreada por altas taxas de desemprego $(47,3 \%)$ e pelo baixo rendimento da população. Enquanto a manutenção das palafitas e moradias semiconsolidadas não representava nenhum gasto adicional ("valor de uso"), permitindo ainda o sustento de alimentos provenientes da pesca, os novos inquilinos dos "embriões" sem rendimento estável agora têm que arcar com o ônus da luz, água, despesas corolárias da inserção formal no mercado imobiliário ("valor de troca").

Estes fatores explicam a alta rotatividade da população no local, que optam por vender sua unidade habitacional para invadir terras vazias em outras localidades. As oportunidades empregatícias do local se restringem ao pequeno comércio, à pesca artesanal e ao trabalho doméstico, o que obriga os habitantes desempenhando atividades formais a longos deslocamentos pendulares em direção ao centro.

Alimenta-se, assim, a reprodução da pobreza através do efeito de cumulatividade de externalidades negativas, resultando da retração do poder público posterior à conclusão do reassentamento, excetuando-se as incursões repressivas da polícia. 
Corroborando com estas observações documentárias, um estudo de caso ${ }^{1}$ realizado no local sobre os padrões de mobilização das redes sociais para a obtenção de um emprego e de recursos (não)materiais demostra que em Novos Alagados prevalece o contexto social local na formação dos vínculos, fato que tende a restringir expressivamente as interações dos seus moradores com indivíduos e grupos sociais não locais.

A maioria dos entrevistados acessa menos bens e serviços, tanto via mercado quanto por ajuda social, já que o alto grau de localismo e homofilia ${ }^{2}$ configurando as redes sociais reduz a circulação de informações sobre oportunidades empregatícias às esparsas potencialidades endógenas do bairro.

1 No quadro da pesquisa qualitativa foram realizadas, no período de maio a novembro de 2015, vinte entrevistas semi- estruturadas de aproximadamente meia hora de duração em distintos locais e horários abrangendo um número equânime de informantes do sexo masculino e feminino, com idade entre 15 e 65 anos e diferente status empregatício. Dentro da amostragem, $40 \%$ dos indivíduos adultos se autoqualificam como desempregados ou sem renda estável, $20 \%$ possuem renda per capita igual ou inferior a um salário mínimo e $40 \%$ dos entrevistados declaram receber entre um a três salários mínimos. A proporção de entrevistados estudantes, grupo não incluído na categoria de Pessoas Economicamente Ativas, chega a 15\%. Durante as visitas ao bairro, era aplicado, em primeiro lugar, um questionário indagando sobre as características gerais do entrevistado incluindo dados biográficos, composição familiar e do domicílio, nível de escolaridade, status empregatício, rendimento médio, trajetória no mercado de trabalho e anos de permanência residencial no bairro. Em segundo lugar, os indivíduos entrevistados foram solicitados a se pronunciar sobre a organização das suas redes egocentradas em termos de participação relativa nas distintas esferas de sociabilidade, quais sejam: família, vizinhança, amizade, trabalho, estudos, vida associativa (não)leiga e diversão/lazer. Os entrevistados deviam fornecer informações mais pormenorizadas sobre a mobilização das redes egocentradas tecidas no âmago das supracitadas esferas para a obtenção de emprego ou de informações sobre vagas, assim como para o acesso a recursos financeiros e de apoio social/emocional.

2 O conceito de homofilia remete ao princípio de que a convergência em determinados atributos sociais como idade, gênero, nível educativo, raça/ etnia, religião, classe ou status social etc. produz uma maior probabilidade de se interrelacionar e de concordar em específicas opinões e práticas similares (McPherson, Smith-Lovin e Cook, 2001, p. 416). 
A mobilização das redes sociais para a obtenção de um emprego ocorre principalmente no âmago das famílias extensas que funcionam como importantes canais pelos quais circulam informações sobre opções de trabalho informal no bairro. A primazia das relações domiciliares no enfrentamento das diversas adversidades cotidianas e na provisão de recursos (não)materiais se explica pela confiança, reciprocidade e solidariedade que estas redes estabelecem entre seus membros a partir de contatos frequentes enquanto prima um alto grau de desconfiança nas relações interpessoais constituídas nas esferas vizinhança e amizade.

Neste sentido, os informantes explicam o encapsulamento das redes e o autoencerramento na esfera domiciliar com a retração do Estado na provisão de bem-estar e de segurança no bairro e pela precariedade do mercado de trabalho.

Cabe ressaltar que apenas dois entrevistados adultos desempenham atividades profissionais com carteira assinada sendo que a grande maioria se encontra em estado desempregado prolongado ou oferece distintos serviços informais no bairro como vendedor ambulante, biscateiro ou assistente de pedreiro, entre outros.

No que tange à distribuição das redes sociais conforme esferas de sociabilidade vizinhança e amizade chama atenção a reticência dos moradores de integrar pessoas desconhecidos nas redes existentes. Observa-se para este caso um significante declínio da importância da vizinhança como contexto de formação e manutenção dos vínculos que restringe as trocas de sociabilidades e o apoio mútuo a um número muito reduzido de vizinhos, fato que contribui a uma crescente fragmentação territorial das relações interpessoais que se organizam em pequenos núcleos a partir de critérios de proximidade, reciprocidade e confiança.

Além da família, o maior apoio social provém das associações de cunho religioso que fortalecem a coesão e solidariedade intragrupal enquanto mantêm uma estrutura troncada e hermética para não congregados. Estes vínculos 
operam como circuitos de reciprocidade onde circulam benefícios materiais, afetivos e cívicos como ajuda na construção da casa, empréstimos, contatos de emprego, auxílio em situações de doença e de dependência física.

Os habitantes do bairro convergem em apontar a fragilidade das oportunidades educacionais e escassez de creches na região. A exposição a congêneres e grupos de pares residindo no mesmo bairro é avaliada unanimemente como desfavorável à trajetória socioeconômica pelos três alunos adolescentes entrevistados que reclamam da falta de perspectivas e da baixa qualidade do ensino.

Outrossim, o acesso a opções de lazer, concentradas nas centralidades de Salvador (shopping centers, cinema, praias), permanece fora do alcance dos moradores entrevistados, já que as despesas para deslocamento e consumo extrapolam o orçamento.

\section{Considerações finais}

O caso de Novos Alagados evidencia que as intervenções habitacionais, em vez de promover estratégias incentivando o desenvolvimento local, limitavam-se a medidas minimalistas que não transcendem esforços de inclusão socioeconômica dos seus moradores. $\mathrm{O}$ assistencialismo excludente reafirma a lógica da "segregação programada" que confina a classe baixa para áreas periféricas já fortemente prejudicadas pelo laissez-faire do poder público, processo que, em retorno, realimenta a reprodução das desigualdades sociais.

O corrosivo efeito de externalidades negativas é potenciado em áreas desassistidas, socialmente homogêneas, bloqueando a mobilidade econômica e arriscando-se a transformá-lo em um local socialmente invisível e territorialmente estigmatizado já que desvinculado dos outros estratos sociais da cidade. 
O caráter paliativo-emergencial dos programas habitacionais se repete em outras intervenções de recuperação de áreas precárias em Salvador que atingem regiões socialmente homogêneas habitadas por populações pobres (Alagados), sem, no entanto, promover uma melhoria sustentável do quadro geral.

Concluindo, cabe ressaltar que a clusterização de múltiplas desvantagens na escala do bairro, evidenciado no estudo de caso em Novos Alagados, sinaliza pela importância de levar em consideração a estratificação espacial das desigualdades socioeconômicas nas cidades dentro da elaboração de políticas de intervenção urbana.

\section{Bibliografia}

Beauregard, Robert A.; Haila, Anne. The Unavoidable Continuities of the City. In: Marcuse, Peter; Van Kempen, Ronald, Globalizing Cities: a new spatial order? Oxford: Blackwell, pp. 22-36, 2000.

Cardoso, Fernando Henrique; Faletto, Enzo. Dependência e Desenvolvimento na América Latina. Rio de Janeiro: Zahar, 1970.

Carvalho, Inaiá M. M. de; Pereira, Gilberto C. (Eds.). Salvador: transformações na ordem urbana: metrópoles: território, coesão social e governança democrática. Rio de Janeiro: Letra Capital, 2014.

Castells, Manuel. A questão urbana. Rio de Janeiro: Paz e Terra, 1983.

Germani, Gino. A sociologia da modernização. São Paulo: Mestre Jou, 1974.

Gordilho-Souza, A. Favelas, invasões e ocupações coletivas nas grandes cidades brasileiras - $(\mathrm{Re})$ Qualificando a questão para Salvador - BA. Cadernos Metrópole, vol. 5, pp. 62-89, 2001. 
Gottdiener, Mark; Feagin, Joe R. The paradigm shift in urban sociology. Urban Affairs Quarterly, vol. 24, $\mathrm{N}^{\circ} 2$, pp. 163-187, 1988.

Harvey, David. A Justiça Social e a Cidade. São Paulo: Hucitec, 1980.

Kowarick, Lúcio. Capitalismo e marginalidade na América Latina. Rio de Janeiro: Paz e Terra, 1975.

Kowarick, Lúcio, L. A espoliação urbana. Rio de Janeiro: Paz e Terra, 1979.

Lewis, Oscar. The Culture of Poverty. In: Moynihan, Daniel Patrick (Ed.), On understanding poverty. Perspectives form the Social Sciences. New York, N.Y.: Basic Books, pp. 187-200, 1968.

Logan, John R.; Molotch, Harvey. Urban Fortunes: The Political Economy of Place. Berkeley: University of California Press, 1987.

Lomnitz, Larissa. ¿Cómo sobreviven los marginados? México: Siglo XXI, 1975.

Marcuse, Peter; Van Kempen, Ronald. Introduction. In: Globalizing Cities. A New Spatial Order? Malden, M.A.: Blackwell Publishing, pp. 1-21, 2000.

McPherson, M.; Smith-Lovin, L.; Cook, J. M. Birds of a feather: Homophily in social networks. Annual Review of Sociology, vol. 27, pp. 415-444, 2001.

Nun José. Sobrepoblaci6n relativa, ejército industrial de reserva y masa marginal. Revista Latinoamericana de Sociología, vol. 5, N² 2, pp. 178-236, 1969.

Park, Robert Ezra. A cidade: sugestões para a investigação do comportamento humano no meio urbano. In: Velho, Otávio G. (ed.), O fenômeno urbano. Rio de Janeiro: Guanabara, pp. 26-67, 1987 [1915].

Park, Robert Ezra; Burgess, Ernest W.; Mckenzie, R. D. The City. Chicago: University of Chicago Press, 1925.

Perlman, Janice E. The myth of marginality. Urban poverty and politics in Rio de Janeiro. Berkeley: University of California Press, 1976. 
144 - Segregación socio-espacial en las ciudades latinoamericanas

Sassen, Saskia. The Global City: New York, London, Tokyo.

Princeton, N. J.: Princeton University Press, 1991. 


\title{
Reestruturação urbana, novos produtos imobiliários e segregação socioespacial en cidades médias brasileiras
}

\author{
O caso de Santa Cruz do Sul
}

ROGÉRIO LEANDRO LIMA DA SILVEIRA

\section{Resumo}

No Brasil, a urbanização das metrópoles e das cidades médias têm se caracterizado por intensa e desigual valorização do solo urbano e consequente reestruturação urbana. Nas duas últimas décadas esse processo tem apresentado a crescente promoção de condomínios e loteamentos fechados enquanto novos produtos imobiliários residenciais, que representam importantes condicionantes e reflexos na organização espacial das cidades e na dinâmica de desenvolvimento e de planejamento urbano. $\mathrm{O}$ trabalho analisa esse processo na cidade média de Santa Cruz do Sul, localizada no estado do Rio Grande do Sul, no sul do Brasil, principal centro agroindustrial do tabaco no país.

Aborda-se as relações e contradições existentes entre os atores sociais e o Estado, no âmbito do mercado imobiliário local e como as mesmas têm incidido na produção desses novos produtos imobiliários na cidade, e seus reflexos para a segregação socioespacial e fragmentação do espaço urbano.

\section{Palavras chave}

Reestruturação urbana; condomínios residenciais fechados; segregação socioespacial. 


\section{Introdução}

No Brasil, as cidades, notadamente as metrópoles e as cidades médias, têm experimentado no período contemporâneo os reflexos da reestruturação produtiva em sua dinâmica de produção e reprodução do espaço construído, sobretudo no âmbito do uso residencial e comercial do território, evidenciando um intenso e complexo processo de reestruturação urbana.

Os processos de produção do espaço urbano e de urbanização têm sido caracterizados por intensa e desigual valorização do solo urbano e consequente reestruturação urbana. Nas duas últimas décadas esse processo tem sido caracterizado pela crescente promoção de condomínios e loteamentos fechados, enquanto novos produtos imobiliários residenciais, que representam importantes condicionantes e reflexos na organização espacial das cidades e na dinâmica de desenvolvimento e de planejamento urbano.

Ainda que a origem, dinâmica e as características gerais desses processos já tenham sido examinadas em diferentes cidades brasileiras ${ }^{1}$, é preciso avançar na análise empírica do modo como esses processos se concretizam nas diferentes regiões do território, e em cidades com distintas posições, funções e tipos de interações no âmbito da rede urbana, a fim de podermos aprofundar o conhecimento em relação às suas particularidades e especificidades, e aos seus reflexos na organização e reprodução do espaço urbano.

É com esse propósito que desenvolvemos nesse trabalho a análise dos processos recentes de urbanização, de reestruturação urbana e de valorização imobiliária na cidade média de Santa Cruz do Sul, principal polo agroindus-

1 Já há uma importante e considerável produção teórica sobre os reflexos da reestruturação produtiva no espaço geográfico, ensejando uma reestruturação espacial, sobretudo em relação ao espaço urbano metropolitano, como desenvolvido por Santos (1990) e Lencioni (1995). Tal temática também vem sendo objeto de reflexão em relação às cidades médias brasileiras, como abordado por Amorim (2001) e Sposito (2006, 2007a e 2007b). 
trial de tabaco do país, centro sub-regional da rede urbana gaúcha e centro econômico comercial e de serviços da região do Vale do Rio Pardo, localizada na área centro oriental do Rio Grande do Sul.

A cidade de Santa Cruz do Sul possui 105 mil habitantes (Censo IBGE, 2010) e se constitui desde 1970, como o principal centro de produção agroindustrial, comercialização e processamento industrial do tabaco, e onde estão instaladas as sedes no país das principais subsidiárias das corporações multinacionais do tabaco que atuam no território brasileiro. Essa condição ao mesmo tempo em que revela a profunda dependência da economia urbana à instável dinâmica do mercado mundial de tabaco e de cigarros, também caracteriza a cidade como um importante e estratégico nó da rede urbana regional que recebe, intermedeia e difunde para o conjunto das demais cidades e áreas rurais da região do Vale do Rio Pardo, e das demais regiões produtoras de tabaco do Brasil, as informações, normas e regulações, e capitais advindos das sedes das corporações multinacionais no exterior e dos principais centros mundiais de comercialização.do tabaco.

Nos últimos vinte anos, a cidade reforçou sua posição de centro intermediário na rede urbana regional e estadual através do desenvolvimento e consolidação da sua função de centro regional de atividades comerciais com certa especialização e de serviços ligados ao segmento educacional e da saúde. Esse crescimento econômico foi acompanhado por intenso e desigual processo de urbanização, com ampliação progressiva do perímetro urbano, do aumento da verticalização da cidade na área central, com o surgimento de ocupações irregulares pela população de baixa renda na periferia urbana, bem como pela produção de novos produtos imobiliários através da construção de loteamentos fechados e condomínios residenciais em áreas intermediárias e periféricas da cidade. 
Neste trabalho abordamos como as relações e contradições advindas dos interesses, das ações e interações de proprietários fundiários, promotores e incorporadores imobiliários locais e externos, e do Estado (sobretudo no âmbito do executivo e legislativo municipal) têm incidido ativamente na produção desses novos produtos imobiliários na cidade. Também analisamos, como a crescente demanda por novos produtos imobiliários localizados em loteamentos e condomínios fechados por parte de segmentos da população com alta renda, como profissionais liberais e empresários e executivos do setor do tabaco, demais ramos industriais e do setor de serviços, tem igualmente contribuído com a nova dinâmica de produção e reprodução do espaço urbano, através do aumento da segregação espacial, da fragmentação urbana e da apropriação de espaços públicos, advinda do fechamento de loteamentos e da constituição de condomínios residenciais de lotes.

A metodologia utilizada envolveu o levantamento de dados secundários sobre a dinâmica do desenvolvimento urbano, da evolução demográfica e econômica da cidade, junto ao IBGE e à FEE-RS; a busca de dados e informações sobre a produção e comercialização de loteamentos e condomínios fechados junto à Prefeitura Municipal, Cartório de Registro de Imóveis, Incorporadoras e Imobiliárias; a utilização de imagens de satélite para melhor representar espacialmente esses processos através do mapeamento temático da evolução urbana, e da localização dos novos produtos imobiliários na cidade em sua relação com o Plano Diretor e o zoneamento de usos do solo, com o zoneamento fiscal e a planta de valores, e com características do sitio urbano.

O trabalho está constituído de três tópicos. Inicialmente discutimos o conceito de reestruturação e sua relação com a reestruturação espacial urbana, destacando algumas considerações teóricas e metodológicas sobre os processos de reestruturação espacial e de valorização imobiliária nas 
cidades médias, e sobre os reflexos da produção de loteamentos e condomínios residenciais fechados, concebidos e comercializados como novos produtos imobiliários.

Em um segundo tópico, abordamos os processos recentes de urbanização e reestruturação urbana da cidade de Santa Cruz do Sul, destacando alguns aspectos da sua configuração espacial.

Por fim, no último tópico analisamos os processos de promoção e de instalação na cidade dos novos produtos imobiliários, os principais agentes sociais e suas estratégias de ação, e as políticas de regulação e de fiscalização do Estado que incidem na produção dos condomínios residenciais e loteamentos fechados. Analisamos igualmente as especificidades desses empreendimentos em Santa Cruz do Sul e seus reflexos na dinâmica socioespacial da cidade.

\section{Reestruturação urbana e produção de novos produtos imobiliários}

Os diferentes ciclos econômicos influenciaram as relações comerciais e de produção na região do Vale do Rio Pardo, com destaque para a transição entre os séculos XIX e $\mathrm{XX}$, em que a tradicional produção agropecuária vinculada às oligarquias regionais foi confrontada com as novas formas de organização social e econômica proporcionada pela agricultura familiar, pautadas pelos investimentos externos na fumicultura. Naquele contexto tiveram importante ponto de representação socioespacial o espaço urbano que se estruturou e reestruturou de acordo com os efeitos de cada ciclo econômico, alterando as relações intraurbanas e interurbanas. Esta materialização das relações econômicas no espaço urbano passou por transformações ao longo do decorrer temporal, e pode-se dizer que a cada recomeço estrutural criou novas condições e possibilidades desafiadoras. 
O termo reestruturação está relacionado a freadas e rupturas com os conceitos econômicos vigentes para recomeçar e se reestruturar diante das disputas econômicas pela sobrevivência dos territórios no mundo capitalista. Estes recomeços não aconteceram automaticamente após as crises, nem tampouco tiveram seus resultados já prédeterminados. Eram como "tiros no escuro" em busca de algo incerto que poderia ter êxito ou não, causando embates sociais e nos costumes existentes, devido a inúmeros fatores, dentre eles o poder econômico e pelo mando da produção que controlavam a vida urbana (Soja, 1993).

A reestruturação urbana está intimamente relacionada às mudanças econômicas de uma sociedade tendo como resultado modificações dos setores sociais e políticos e principalmente na configuração do espaço urbano. A reestruturação interna ou intraurbana como preferimos chamar, provocou "a desconcentração e a reconcentração dos espaços de assentamento e dos complexos de produção, transformando regiões metropolitanas em aglomerações estendidas, multinodais e multicêntricas" (Soares, 2006, p.5).

Com a reestruturação observa-se uma tendência à descentralização e dispersão. Descentralização relacionada à criação de novas centralidades, novos polos de crescimento e desenvolvimento impulsionados por empresas transnacionais e pela facilidade de comunicação e mundialização do capital. Dispersão relacionada com o aumento da malha urbana e com a modificação das relações sociais no espaço das cidades. Cada vez mais se observa empreendimentos distantes do núcleo central das cidades, valorizando áreas até então sem valor financeiro, modificando as relações centro x periferia (Sanfelici, 2010). 
Para Neil Smith, a reestruturação da economia "espacialurbana" é produto simultâneo do desenvolvimento desigual do capitalismo, das mudanças nos estilos de vida, da suburbanização do capital e da desvalorização dos investimentos no ambiente construído. (Soares, 2006, p.165).

Com o fim da Segunda Guerra Mundial e a instalação de um modelo fordista de produção e acumulação, o mundo viveu um momento de prosperidade econômica marcado pelas novas técnicas de produção em massa e intensa urbanização das cidades. Neste período observa-se além do crescimento populacional, o desenvolvimento comercial, industrial, o início da periferização dos trabalhadores nos subúrbios e da metropolização das maiores cidades. Os trinta anos gloriosos que marcaram o desenvolvimento fordista entraram em crise por volta da década de 1970 quando se passa a viver um novo processo: a acumulação flexível (Baeninger, 1998).

A crise do modelo fordista de produção e acumulação gerou a abertura para novas abordagens baseadas em modernos modelos de produção juntamente com a desindustrialização e a reestruturação das indústrias que abandonavam seus locais de trabalho em busca de novas localizações distantes das metrópoles.

As indústrias se mudam em busca de novas localizações iniciando um processo de deterioração e degradação da área central tradicional das metrópoles então desabitadas pela população. $\mathrm{O}$ mesmo se observou nas zonas fabris que foram abandonadas em detrimento de novas localizações mais providas de benefícios como a facilidade na obtenção de matéria prima. Foi marcante a desindustrialização das metrópoles, é o “começo do fim” (Soares, 2006, p.5).

Até os anos 1970 e 1980 a estrutura urbana das cidades era baseada num esquema centralizado, em torno de um centro principal que detinha as atividades comerciais e de serviços. No entanto, nos últimos vinte anos, foram criados novos centros nas cidades contemporâneas que se tornaram 
pontos de atração de investimentos, usuários e moradores tornando a cidade multipolarizada ou multicentralizada e com investimentos melhor distribuídos na malha urbana (Sposito, 2007).

Até o início do século XX as cidades tinham características basicamente centralizadas, e eram suporte e produto da divisão social, técnica e territorial do trabalho em escalas diferentes. Como expressão dessa realidade, as relações entre centro e periferia constituíam-se como a base da reprodução da vida cotidiana citadina (Santos, 2006).

As modificações intra e interurbanas das cidades contemporâneas alteram as relações entre as cidades de diversas formas. Uma delas é a modificação dos fluxos migratórios que exercem atração e repulsão de pessoas para estas regiões. Alguns moradores das cidades próximas são atraídos pelas modificações urbanas e melhorias tecnológicas que as cidades dispõem. Em contrapartida exercem o fenômeno de repulsão das pessoas da zona rural para a zona urbana em busca desta vida moderna disponível nas cidades mais desenvolvidas (Freitas, 2010).

As cidades médias apresentam melhores condições para o desenvolvimento de atividades atraindo empresas, pois dispõem de mão de obra qualificada, isenção fiscal promovida pelo poder público para atrair as empresas e um crescente nível de consumo facilitado pelas redes de transporte disponíveis e ainda não saturadas como acontece nas metrópoles (Freitas, 2010).

É preciso também considerar que os processos de produção do espaço urbano e de urbanização nas cidades brasileiras têm sido caracterizados por intensa e desigual valorização do solo urbano e consequente reestruturação urbana (Smolka, 1992). Nas duas últimas décadas, especialmente, esse processo tem sido caracterizado pela crescente promoção de condomínios e loteamentos fechados, enquanto novos produtos imobiliários residenciais que apresentam importantes condicionantes e reflexos na organização espacial e na dinâmica de desenvolvimento e de planejamento 
urbano das cidades. Como lembra Sposito (2006, p.176), "a diversidade de suas formas de produção e uso, bem como as decorrências desse fenômeno são de tamanha dimensão que se pode afirmar que têm grande peso na reestruturação das cidades contemporâneas em que aparecem e nas práticas socioespaciais dos moradores desses espaços, bem como dos que ficam fora de seus muros.” Em Silveira, Pereira e Ueda (2006) percebemos como esse processo tem se apresentado notadamente nas metrópoles brasileiras e latino-americanas.

A lógica predominante de produção do espaço urbano tem seguido a racionalidade do processo de reprodução do capital imobiliário, no qual, como lembra Harvey (2006), existe a permanente necessidade de circulação do capital no ambiente construído, alimentando um movimento constante de especulação e de construção de novas configurações espaciais, como as representadas pelos condomínios e loteamentos fechados.

A implementação desses novos produtos imobiliários residenciais nas cidades brasileiras tem revelado um processo de reestruturação urbana, com alterações no padrão de organização espacial centro x periferia, e redefinições no tradicional significado e conteúdo social e econômico da periferia urbana. A produção e comercialização desses novos empreendimentos imobiliários além de resultarem da articulação dos interesses de diferentes atores em torno da apropriação privada da renda da terra e dos ganhos imobiliários da comercialização dos imóveis, revelam também em sua materialização no espaço urbano um intenso processo de segregação socioespacial, e mesmo de autossegregação das classes mais abastadas através da construção de verdadeiros "enclaves fortificados" na cidade, intensificando a fragmentação urbana. (CALDEIRA, 2003 e SABATINI, 2001). 


\section{A estruturação urbana de Santa Cruz do Sul}

O espaço urbano da cidade de Santa Cruz do Sul se caracteriza pela desigualdade social segmentada, de um lado, pelo eficiente sistema de infraestrutura e acesso aos equipamentos e serviços urbanos em determinadas áreas como o centro e zona norte da cidade, e de outro, pelas precárias condições de habitação, evidenciando o fenômeno da segregação na cidade, assim como também acontece no restante de nosso país. Ao longo de seu processo de desenvolvimento, Santa Cruz do Sul assistiu ao crescimento em suas bordas de inúmeras vilas operárias que, no decorrer dos anos, multiplicaram-se, abrigando a população de baixa renda, intensamente mobilizada pelo capital transnacional para o trabalho temporário na agroindústria do tabaco.

Nos últimos vinte anos, a economia urbana de Santa Cruz do Sul vem experimentando relativa diversificação econômica, sobretudo pelo crescente papel do comércio e dos serviços na dinâmica produtiva e urbana da cidade. Há crescente complexificação de suas funções urbanas com o desenvolvimento de um conjunto de atividades complementares à fumicultura, nos setores de comercialização, de crédito, de logística e tecnologia, bem como pela dinamização do comércio e setor de serviços - a cidade tem graus maiores de centralidade urbana no âmbito da região.

Em Santa Cruz do Sul tivemos nesse período a instalação de novos e modernos objetos técnicos como shopping centers, centros comerciais, lojas de conveniência e lojas especializadas. No setor de saúde, foram criadas inúmeras clínicas médicas e odontológicas especializadas, casas de repouso, spas, clínicas de fisioterapia e laboratórios especializados. No âmbito do lazer, criaram-se cinemas, casas noturnas, bares temáticos, restaurantes especializados, centros culturais, livrarias e agências de viagem. Com o aumento da urbanização 
e do desemprego na região, ampliaram-se os índices de violência nas cidades da região e, com ela, tivemos também a criação de empresas especializadas na vigilância residencial e comercial, bem como de empresas de segurança privada.

Desse modo, e diante da importância de Santa Cruz do Sul no âmbito da economia regional, em termos da oferta diversificada de serviços, arrecadação de tributos, geração de empregos e renda per capita, essa cidade atualmente se credencia como o principal nó da rede urbana regional. Os reflexos desse intenso processo de urbanização, e de maior complexificação dos usos do território na configuração espacial da cidade têm sido a crescente expansão da área urbana e da verticalização da cidade. Em relação à expansão espacial da área urbana, observa-se na figura 01 que sobretudo, a partir dos anos 1990 novas áreas no entorno da cidade passaram a ser incorporadas à malha urbana, ampliando o perímetro urbano da cidade. Tal processo ocorreu de modo diferenciado nas distintas áreas da cidade.

$\mathrm{Na}$ zona sul da cidade, a partir da instalação de novas empresas de tabaco e do setor metal-mecânico no distrito industrial houve a produção de inúmeros loteamentos populares, alguns realizados de modo irregular, demandado posteriormente a ação da prefeitura para regularizá-los, e outros resultantes de programas oficiais de habitação popular criados pelo governo municipal ou pelo governo federal, como o Minha Casa Minha Vida. 
- Segregación socio-espacial en las ciudades latinoamericanas

Figura 01 - Evolução do perímetro urbano de Santa Cruz do Sul:

1975 a 2012

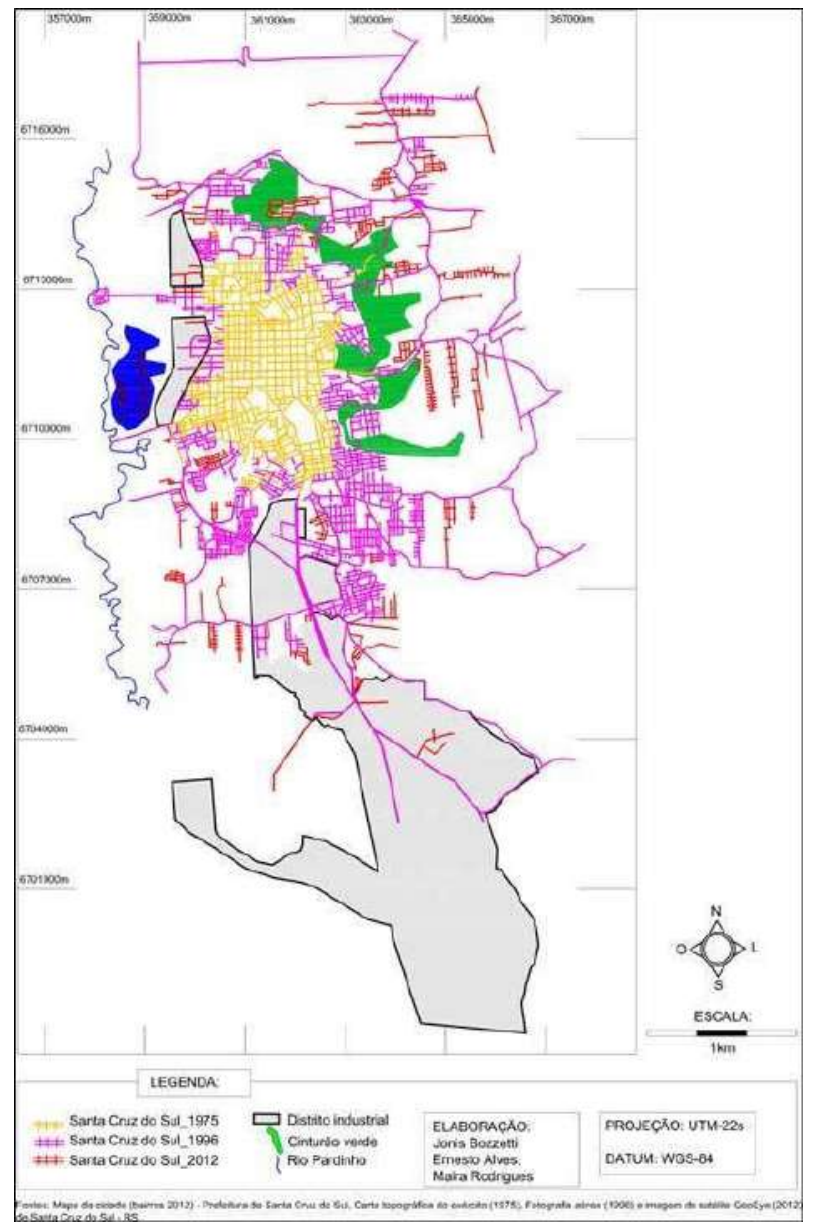

Fonte: Elaborado pelo autor com base nos dados da Prefeitura Municipal de Santa Cruz do Sul. 
Esses novos loteamentos que foram sendo instalados nessa região da cidade tiveram como principal público de destino a população de baixa renda, constituída sobretudo por trabalhadores safristas que atuam na indústria do fumo e na indústria da construção civil. A localização desses loteamentos em áreas distantes do centro da cidade e dos principais equipamentos urbanos e serviços, e apresentando precária infraestrutura urbana possibilitou a comercialização de lotes com valores mais baixos no mercado imobiliário local, atraindo assim esse segmento social da população.

Já na zona norte da cidade, junto ao Cinturão Verde que circunda a cidade, observa-se a partir do final dos anos 1990 e principalmente a partir de 2002, a produção de novos produtos imobiliários com a construção de loteamentos e condomínios fechados. Esses novos empreendimentos imobiliários construídos com alto padrão, foram realizados para atender a demanda da população de alta renda que buscava residir em áreas próximas do centro da cidade, mais seguras e próximas à natureza.

\section{Os agentes produtores do espaço urbano e suas estratégias de ação}

O crescimento e as transformações da forma urbana são decorrentes, principalmente da ação de agentes como os construtores, empreendedores e empresas que atuam no ramo da construção civil. Concomitantemente a estes agentes a forma da malha urbana delineada ao longo do desenvolvimento deste município também sofreu forte influência dos pequenos investidores e proprietários de terras que atuam neste ramo como uma forma de investir seu capital. Neste item busca-se destacar alguns dos principais agentes 
produtores do espaço urbano verificáveis nas cidades estudadas pela pesquisa realizada, em particular em Santa Cruz do Sul.

Um primeiro tipo são os grandes empreendedores e proprietários fundiários, tais como industriais e comerciantes que adquirem imóveis como forma alternativa de investimento, injetando recursos e incentivando a construção civil. Esta prática acontece geralmente com a compra do imóvel nos estágios iniciais da construção ou ainda anterior ao seu início, momento em que ainda é possível ter acesso a valores de imóveis inferiores ao praticado pelo mercado quando o imóvel já está executado e pronto para ocupação. Neste momento as construtoras necessitam de maior quantidade de capital para iniciar a construção.

Estes agentes participam da produção do espaço urbano em diferentes escalas, variando desde o pequeno construtor individual que age num determinado ponto da malha urbana até o poder público que tem poder de influenciar e direcionar o desenvolvimento da cidade como um todo. De forma menos explícita, pode-se identificar no mercado de imóveis empresários de distintos ramos investindo seu capital na construção de condomínios.

A opção por investimentos em terras e imóveis como fonte de recursos é uma prática tradicional de proprietários fundiários, sejam eles grandes empreendedores ou não. Independente do uso de determinado investimento, é possível que este uso se altere e seja reorientado buscando maior atratividade e maior lucratividade para o investidor, funcionando como moeda de troca em momentos de escassez de recursos.

O segundo tipo está associado aos agentes externos ao mercado imobiliário que passam a atuar na construção de imóveis. Os agentes não diretamente vinculados ao mercado imobiliário podem exercer influência neste setor ao instituírem pequenas construtoras que atuam de forma isolada. Estes empreendedores trabalham com mão de obra terceirizada investindo em construções de condomínios de 
pequeno porte, buscando neste empreendimento um retorno financeiro. Muitas destas construtoras não empreendem mais de um condomínio, sendo dissolvidas após a conclusão da construção. A percepção de que o mercado imobiliário e de construção civil é um ramo muito lucrativo ilude alguns empreendedores que se aventuram neste ramo.

O terceiro tipo de agentes são as lojas de materiais de construção que, assim como as imobiliárias, também atuam na construção de sobrados. Firmando parcerias com os proprietários dos lotes a realização de permutas no próprio local é a estratégia mais utilizada por estes agentes. Outra forma de atuação do comércio de material de construção na edificação de sobrados pelos empreendedores individuais e pequenas construtoras é o financiamento do material de construção adquirido para a execução da obra. As lojas de material de construção vendem as mercadorias para receber somente após a venda da unidade residencial, independentemente do tempo de espera. A cobrança de juros por este financiamento é vantajosa para as lojas, mas também acaba beneficiando o pequeno empreendedor, que não necessita utilizar grandes quantias de capital na construção do empreendimento.

Há ainda os proprietários de parcelas de solo urbano que realizam permutas para a construção de condomínios, que firmam parcerias com construtoras fornecendo o lote para que elas construam e em troca recebem uma unidade residencial nos condomínios de sobrados. É uma outra escala de atuação de um mesmo agente que tem forte influência na produção da cidade.

Por fim, há o Estado. A participação do Estado está associada, entre outras práticas, ao processo de regulação dos processos de aprovação e fiscalização do território municipal. Uma questão importante apontada por técnicos municipais diz respeito à inexistência de legislação sobre condomínios de qualquer tipo. A legislação municipal e os procedimentos técnicos limitam-se ao veto da construção de sobrados em quatro setores, sem definir dimensões 
mínimas dos compartimentos nem limitar o número de sobrados a serem construídos em cada lote ou área da cidade. Não se pode negar, no entanto, que a maior contribuição do Estado, portanto, está na estruturação da legislação municipal diretamente associada à organização do território municipal: o Plano Diretor.

A produção dos novos produtos imobiliários na cidade de Santa Cruz do Sul tem sido acompanhada por um crescente processo de segregação socioespacial experimentada pelas classes sociais abastadas da cidade. Tal processo decorre de distintas variáveis que de certo modo se complementam em uma dada racionalidade que acaba justificando e explicando a demanda existente na cidade pela aquisição desses novos produtos.

Uma primeira razão é aquela advinda do clima de insegurança, medo e violência urbana que a cidade, com sua intensa e desigual urbanização passou a experimentar nesse período.

As campanhas de marketing contratadas pelas empresas incorporadoras para divulgação dos novos empreendimentos imobiliários na cidade superestimam e manipulam esses dados, de modo a justificá-los. Assim, elas costumam valorizar a sensação de segurança que o ato de morar em um loteamento ou condomínio fechado pode representar, diante do clima de violência, medo e insegurança generalizados que vigora fora dos muros dos novos empreendimentos.

Em Santa Cruz do Sul, progressivamente os novos produtos imobiliários vão se afirmando como a negação do espaço público, do espaço do encontro, da alteridade, de encontrar e conviver com o outro, com o diferente, dialeticamente afirmando sua identidade na cidade. A cidade pequena com alto controle social, e muitos pontos de encontro, gradativamente é substituída pela cidade dos espaços murados. 
O espaço, antes contínuo, alternando diferentes usos, mas mantendo a coesão territorial e a integração espacial, advinda da articulação do sistema viário, vai dando lugar a uma cidade crescentemente fragmentada, separada, cujos diferentes espaços e distintas tipologias, seguem a lógica de reprodução do mercado imobiliário, e ao fazê-lo afirmam um modelo de organização espacial segregador e desigual tanto em termos sociais, políticos e culturais.

Outra razão para este fenômeno de reestruturação urbana se refere ao valor diferenciado de uso e de troca que os novos produtos imobiliários buscam oferecer aos consumidores desses empreendimentos, através da sua localização na cidade, do tipo de constituição, dos equipamentos e serviços disponibilizados aos consumidores.

Observando o conjunto dos novos produtos imobiliários construídos na cidade nos últimos quinze anos verificamos a existência de uma ampla diversidade de tipos, desde aqueles produzidos originalmente como loteamentos e em seguida modificados com o fechamento dos acessos públicos, aos empreendimentos de alto padrão, planejados desde a concepção como condomínios urbanísticos.

Um exemplo importante que revela muitos desses processos é o Condomínio Reserva dos Pássaros, construído a partir de 2008 pela incorporadora João Dick Imóveis Ltda., empresa de capital local, em área junto ao Cinturão Verde. (Figura 02). O empreendimento foi registrado na Prefeitura Municipal como Loteamento Condomínio Reserva dos Pássaros, denotando o seu conteúdo contraditório, pois ao mesmo tempo que possui sua estrutura organizada em uma área fechada com muros, de $375.254,57 \mathrm{~m}^{2}$ dividida em 325 lotes, vias internas de acesso e comunicação, áreas verdes e de lazer, os proprietários adquirem e registram seus lotes de modo individualizado.

Portanto, esse empreendimento imobiliário é em sua essência um loteamento, pois apresenta lotes para venda e não unidades de habitação. Os lotes, estão localizados em ruas internas, e estas deveriam, uma vez 
configurado o loteamento, serem doadas ao poder público municipal, para uso e circulação pública e não apenas dos moradores que residem nos lotes do "condomínio" fechado. Ou seja, o condomínio fechado de lotes que caracteriza esse empreendimento, é em realidade um loteamento fechado.

A construção do empreendimento imobiliário foi realizada através da contratação, pela incorporadora, de outras empresas prestadoras de serviços especializados. A Empresa Construtora Rech Ltda. foi a empresa responsável pela terraplanagem, abertura das vias internas, instalação da infraestrutura e urbanização da área, preparando-a para a comercialização dos lotes. A empresa Projeto: Arquitetura e Construções, também de Santa Cruz do Sul, foi a responsável por projetar e construir as áreas de uso social como espaço gourmet, fitness, quiosque, administração, portaria e salões de festas. Quanto à comercialização dos lotes, está é feita exclusivamente pela empresa João Dick Imóveis, que assim acaba concentrando nela a maior parte do capital advindo da venda dos lotes.

Observando a Figura 02, verifica-se o alto padrão de construção do empreendimento bem como sua localização diferenciada, já que o mesmo apresenta em seu entorno contíguo as áreas de matas que compõem o Cinturão Verde da cidade. Além disso, existe no interior do empreendimento uma área verde de preservação, com $7.691 \mathrm{~m}^{2}$. 


\section{Figura 02 - Loteamento Condomínio Urbanístico Reserva dos Pássaros - Santa Cruz do Sul}

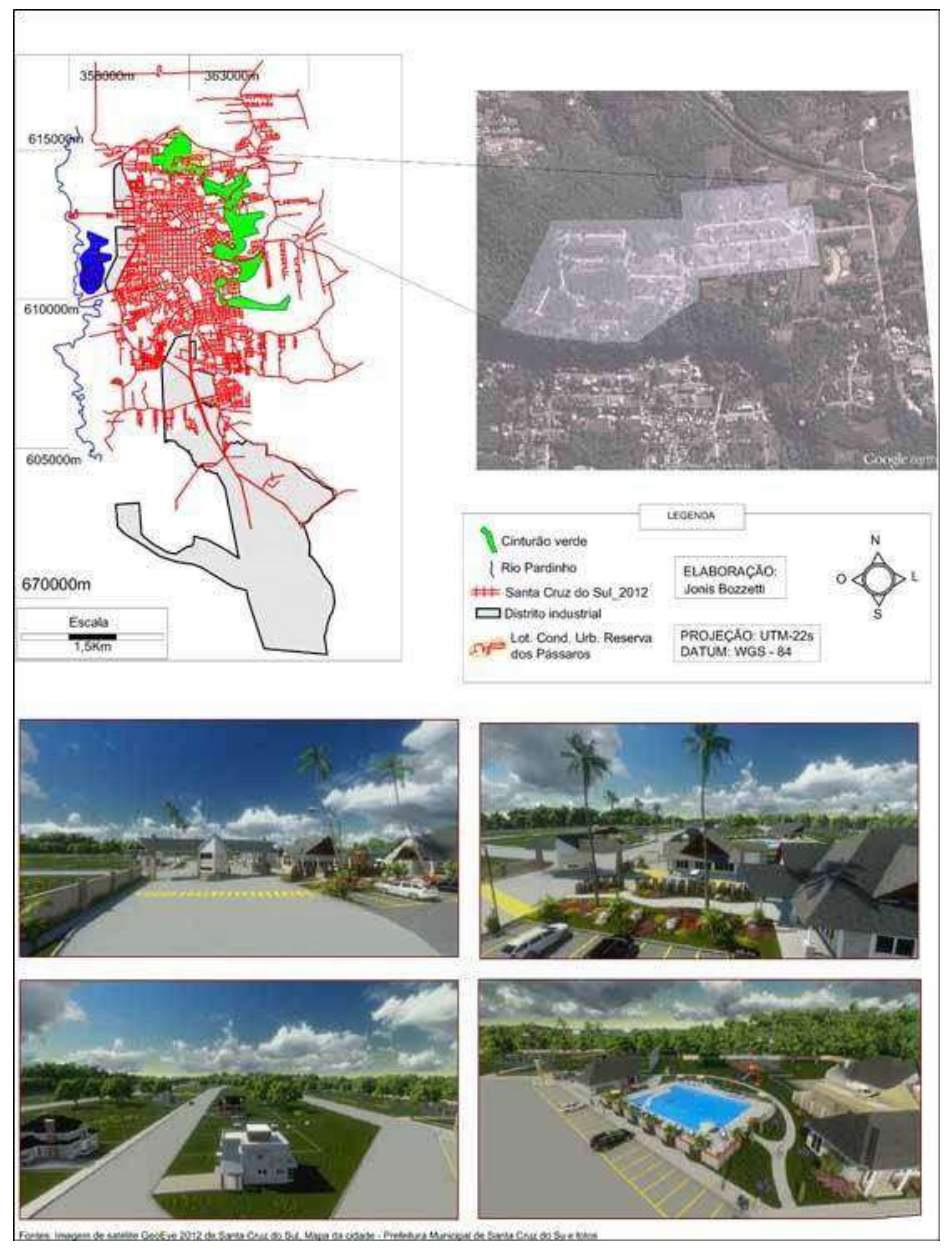

Fonte: Elaboração do autor com base na imagem de Satélite GeoEye 2012 e dados do empreendimento imobiliário. 
Tal condição possibilita ao incorporador obter, no ato da comercialização dos lotes, uma dada renda diferencial da terra, advinda da compra do acesso a esses atributos diferenciados do empreendimento. Também, contribuem e reforçam essa condição a oferta de equipamentos e serviços de uso exclusivo dos futuros moradores, como por exemplo: portaria 24 horas, vigilância eletrônica, serviço de ronda, serviço de carro leva e traz, dois salões de festas, espaço gourmet, piscina adulta e infantil, campo de futebol, sete quadras poliesportivas, de tênis e de padel.

O conjunto desses equipamentos e serviços qualificam esse novo produto imobiliário e permitem sobrevalorizar o valor de troca dos lotes a serem comercializados, possibilitando ao incorporador obter, quando da efetivação da venda, uma verdadeira renda de monopólio, sobretudo por que há uma demanda para esse tipo de produto, advinda dos segmentos mais abastados da população da cidade.

Além disso, de acordo com o diretor da empresa incorporadora, o que atrai o comprador para a aquisição de lote no condomínio, constituindo-se na principal vantagem para ele, "é o fato de o mesmo se encontrar pronto para construir, em um lugar que já tem tudo. Ou seja, as coisas funcionam bem, não dependendo tanto do poder público e nem da boa vontade ou sorte de vizinhos, porque tem regras construtivas claras".

Esse discurso, comum entre os incorporadores valoriza o caráter autônomo e privado do condomínio, e da sua quase não dependência das ações do poder público quanto ao fornecimento de infraestrutura e serviços, ao mesmo tempo que reforça o caráter de verdadeiro enclave socioespacial na cidade.

Por fim, cabe ainda destacar a constituição de um novo conteúdo socioespacial da periferia urbana que a produção e a ampliação dos novos produtos imobiliários passaram a representar em Santa Cruz do Sul. A Figura 03, que ressalta a distribuição da renda média mensal da população 
na cidade, demonstra a distribuição dos produtos imobiliários de acordo com os padrões econômicos dos diferentes setores da cidade.

Figura 03 - Distribuição da renda média mensal da população em Santa Cruz do Sul - 2010

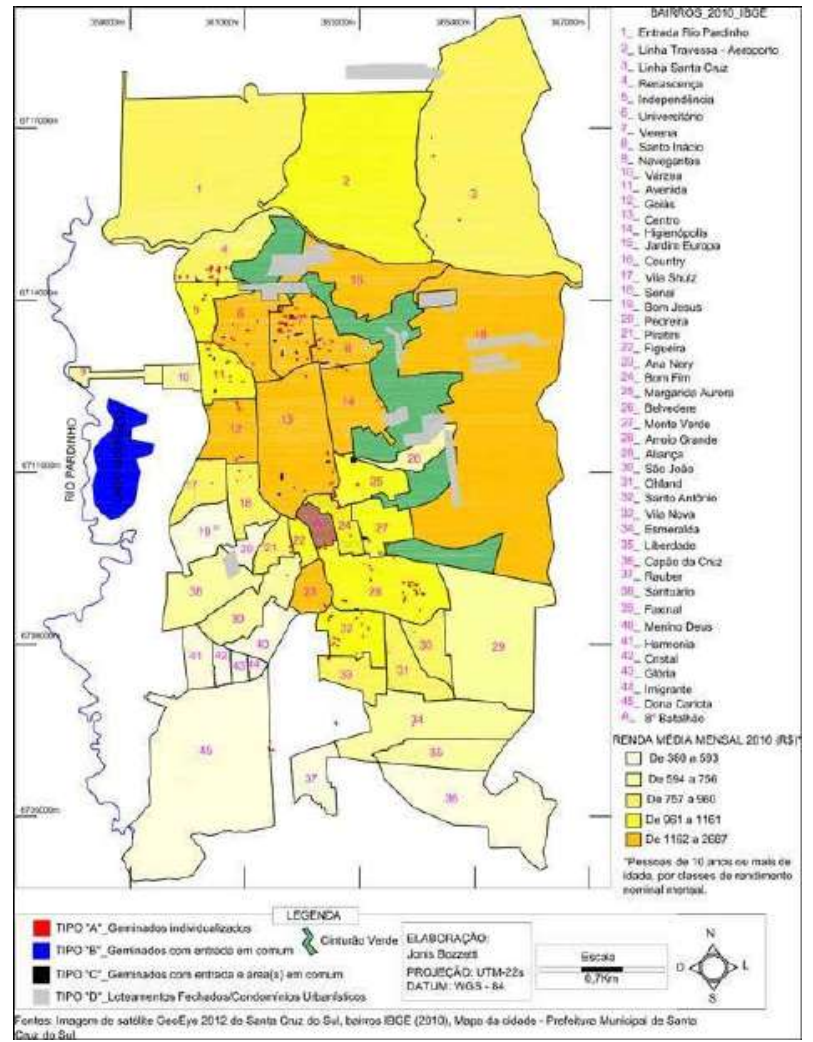

Fonte: Elaboração do autor com base nos dados do IBGE, 2010. 
Observamos que, enquanto na porção sul da cidade a periferia urbana se caracteriza pela presença da população de baixa renda com rendimentos médios mensais abaixo de $\mathrm{R} \$ 756,00$, nas áreas periféricas localizadas ao norte da cidade, por sua vez, vamos encontrar mais recentemente a presença de segmentos da população com maiores rendimentos. Este é o caso das áreas onde estão localizados grande parte dos condomínios e loteamentos fechados, como os vistos acima, em que a renda média da população.

Os dados permitem verificar a existência não apenas do tradicional processo de segregação espacial a que está submetido a população de baixa renda no sul da cidade, mas também o processo de autossegregação da população com maior rendimento em seu processo de localização nas áreas de ocorrência dos novos produtos imobiliários no quadrante norte da cidade. Tal processo tem resultado na fragmentação espacial e na consolidação de uma forte e aparente segregação socioespacial.

\section{Conclusões}

A presença de novos produtos imobiliários e a estruturação do espaço urbano em cidades médias, sobretudo nas duas últimas décadas, revela diferentes formas de influência na dinâmica não apenas urbana, mas regional.

As estratégias dos agentes sociais envolvidos na produção desses empreendimentos podem assumir diferentes formas de organização institucional ou política, mas em geral apoiam-se em fatores recorrentemente verificáveis nas cidades em estudo: valores do solo mais acessíveis, infraestrutura pré-existente e estoque imobiliário ou vazios urbanos disponíveis (dependendo do tipo e tamanho do empreendimento). 
Verificou-se ainda que as distintas tipologias possuem diferentes formas de ocupação do território, desde composições mais facilmente articuladas à dinâmica da cidade existente, como é o caso dos tipos mais abertos, até situações com fortes implicações de alteração do tecido urbano, como é o caso dos grandes empreendimentos fechados.

O estudo oferece oportunidade de compreensão de muitos fenômenos socioespaciais relacionais a esses produtos imobiliários; no entanto, muito há a discutir ainda sobre os avanços tecnológicos utilizados na sua implementação ou ainda nos efeitos comportamentais dos usuários que dele participam ou com ele se confrontam. De qualquer forma, é certo considerar que esses empreendimentos estão inseridos dentro de um entendimento de reestruturação das cidades contemporâneas e, neste sentido, são conteúdos importantes dos estudos urbanos e regionais na contemporaneidade.

\section{Bibliografia}

Amorim Filho, O. Evolução e perspectivas do papel das cidades médias no planejamento urbano e regional. In: Andrade, T.; Valente, R. (Org.), Cidades médias brasileiras. Rio de janeiro: IPEA, pp. 1-34, 2001.

Baeninger, R. Reestruturação urbana: algumas considerações sobre o debate atual. Disponível: <http://www.cprepmauss.com.br/documentos/reestruturacaourbanaealgumasconsideracaes 1647.pdf >. Acesso em: 10/01/2014.

Caldeira, T. P. do R. Cidade de muros: crime, segregação e cidadania em São Paulo (2a. ed.). São Paulo: Ed. 34, 2003.

Freitas, B. R. A morfologia urbana de uma cidade média: considerações sobre Montes Claros. In: Anais do XVI encontro nacional dos geógrafos. Porto Alegre, 2010. 
Harvey, D. A produção capitalista do espaço (2a. ed.). São Paulo: Annablume, 2006.

Lencioni, S. Reestruturação industrial no Estado de São Paulo. A região da Metrópole Desconcentrada. Espaço e Debates, vol. 38, pp. 54-61, São Paulo, 1995.

Sabatini, F. Residential segregation pattern changes in Chile's main cities: scale shifts and increasing malignancy. In: International Seminar on Segregation and the City, Cambridge: Lincoln Institute of Land Policy, 2001.

Santos, M. Metrópole Corporativa Fragmentada: O caso de São Paulo. São Paulo: Hucitec, 1990.

Santos, M. A Natureza do Espaço: Técnica e Tempo, Razão e Emoção (ed. 2. Reimpressão). São Paulo: Editora da Universidade de São Paulo, 2006.

Smolka, M. O. Expulsando os pobres e redistribuindo os ricos - dinâmica imobiliária e (re)estruturação interna na cidade do Rio de Janeiro. Revista Brasileira de Estudos de População, vol. 9, N 1, pp. 24-39, jan/jun 1992.

Soares, P.R.R. Produção imobiliária e crescimento urbano em cidades médias: Pelotas e Rio Grande (RS). In: Silveira, R. L. L. da. et al. (orgs.), Dinâmica imobiliária e reestruturação urbana na América Latina. Santa Cruz do Sul: EDUNISC, pp. 159-192, 2006.

Soja, E. W. Geografias pós-modernas: a reafirmação do espaço na teoria social crítica. Rio de Janeiro: Zahar Editores, 1993.

Sposito, M. E. B. Cidades Médias: Reestruturação das Cidades e Reestruturação Urbana. In: Sposito, M.E.B. Cidades Médias: espaços em transição (1a. ed.). São Paulo: Expressão Popular, pp. 233-253, 2007a.

Sposito, M. E. B. Reestruturação urbana e segregação socioespacial no interior paulista. Revista Electrónica de Geografía y Ciencias Sociales, vol. 21, N ${ }^{\circ} 245$, agosto, 2007b. Disponível em: <http://www.ub.es/geocrit/sn/ sn-24511.htm> 
Sposito, M. E. B. Loteamento Fechados em cidades médias paulistas - Brasil. In: Sposito, Eliseu S.; Sposito, Maria E. B.; Sobarzo, Oscar (Org.), Cidades médias: produção do espaço urbano e regional. São Paulo: Expressão Popular, 2006, pp. 175-197. 



\title{
Regreso al centro con fragmentación urbana
}

\author{
Efectos del repoblamiento inmobiliario \\ en el centro histórico del Gran Santiago
}

\author{
Camilo Arriagada luco
}

\section{Resumen}

La comuna de Santiago se ha sumado a una serie de centros históricos de Latinoamérica y América del Norte que atraen nueva población y comercios después de décadas de despoblamiento y deterioro, configurando espacios que superponen poblaciones de clase media y baja, propias del viejo centro histórico secularmente deteriorado, con nuevas generaciones de residentes jóvenes de mayores ingresos y nivel educativo, individuos que valoran centralidad desde una diversidad de intereses ya sea la accesibilidad a sus centros de estudio y trabajo y el tiempo libre, o la residencia en barrios y viviendas antiguas trasuntando diferencias importantes tanto del perfil como de proyecciones residenciales, relevantes para la formulación de nuevas políticas sociales $\mathrm{y}$ urbanas que, por una parte, regulen la renovación urbana y sus impactos o externalidades negativas, y por otro, permitan gestionar la convivencia y desarrollo de barrios de forma más funcional a la cohesión social vecinal y la recuperación de los barrios. Se destaca que los cambios del perfil demográfico y socioeconómico fueron inducidos por la oferta masiva de proyectos de renovación urbana que operó en Chile contemporáneos de cambios de las economías urbanas, mercados de vivienda y de las preferencias de 
localización de alcance que son un fenómeno globalizado y extendido a nivel internacional. Por este proceso se concentraron la llegada de personas de clases medias atraídas por factores de localización y accesibilidad a empleos y estudios y por la cultura urbana propia del centro, un grupo de clase media baja que se insertó en mercados secundarios de viviendas patrimoniales y obreras versus otro segmento en la compra o arriendo de departamentos nuevos en proyectos masivos ofertados por el sector inmobiliario.

\section{Palabras clave}

Centro Histórico; Barrios; Recentralización.

\section{Introducción}

Este artículo está basado en datos de la Encuesta del Estudio "Evaluación de impacto del desarrollo residencial en la comuna de Santiago 1987-2013 y formulación propuestas de futuro", investigación integrante de los estudios de base para la Actualización del Plan de Desarrollo Comunal de Santiago, encargado por la SECPLAN del Municipio de Santiago durante el mandato de la alcaldesa Carolina Tohá Morales (Convenio SURPLAN/SECPLAN IMS, 2013).

\section{Marco teórico/marco conceptual}

Los estudios del URBAN AUDIT sobre capitales de Europa durante las últimas décadas muestran que la población de los centros urbanos europeos en varios casos vuelve a crecer a tasas aceleradas, más rápidas que su crecimiento económico y empleo, y que se trata de un proceso asociado al repoblamiento de los centros históricos, al incremento de la vivienda en arriendo, a la movilidad de personas y 
a la inmigración internacional, junto con nuevas configuraciones familiares, especialmente hogares unipersonales y parejas sin hijos cuyas expectativas de consumo cultural son elevadas (CEE, 2010 y 2013).

La globalización de la economía ha favorecido procesos de reconfiguración de las ciudades que incluye un movimiento de regreso de la población, la vivienda y el comercio a los centros de las grandes urbes a nivel internacional. En términos económicos la globalización ha significado la desindustrialización y el reemplazo del empleo y barrios obreros por la economía de servicios con grandes lagunas de desafiliación laboral para el grueso de la población. Varios autores, entre otros, Bauman (2000 y 2002) y Kaztman, hablan del reemplazo de la sociedad pesada por la sociedad líquida para destacar la disolución de la sociedad del trabajo y su reemplazo por la sociedad del consumo paralelo de un proceso de individuación que reemplaza espacios de solidaridad colectiva, como las identidades de clases y el barrio como espacios de socialización (Arriagada, 2014).

Los centros se muestran como espacios de crecimiento demográfico como parte del modelo de reconfiguración urbana propio de la nueva economía, donde se conjugan deterioro del espacio público y patrimonio con revitalización económica y residencial en dinámicas empujadas por negocios inmobiliarios importantes. El post 2000 es un momento de la ciudad muy marcado por el proceso de regreso al centro y que tiene su mejor ejemplo de tendencia global nueva en el llamado "fin del suburbio" detectado en las urbes de USA postmudanza de sus industrias a Asia. El concepto de relleno o infilling en planificación urbana alude al redesarrollo de grandes terrenos vacantes o industrias obsoletas (Poduje y otros, 2015).

En efecto, el área metropolitana ha manifestado en un sorprendente crecimiento de coronas centrales en 2002-2012, tras un largo y sostenido despoblamiento en el lapso previo, 1960-2000. (Arriagada, 2014). En este contex- 
to, se han visibilizado transformaciones del nuevo espacio central y tanto la agenda urbana cmo el debate sociológico incorpora referencias a una serie vario pinta de nuevos fenómenos y sujetos ciclistas y Ciclo rutas, Barrios Comerciales y Circuitos de turismo patrimonial, Inmigrantes internacionales, Uso del tiempo libre, etc. Gentrificación, renovación urbana y fragmentación son tres enfoques que ayudan a entender la nueva dinámica de los barrios de los centros de grandes urbes.

La "gentrificación" es un proceso descrito por la literatura desde los sesenta en Londres y en los setenta para USA y Canadá, y hoy es un proceso generalizado en ciudades globales de todas las regiones. Para Smith, este proceso es un negocio de muy alta ganancia que se basa en compras de terrenos a propietarios individuales a bajo precio, proyectos inmobiliarios y luego la venta en unidades de vivienda de alto precio para demanda solvente, que genera renta del suelo. Por efecto de este circuito se producen "saltos de rana" en los precios del suelo que obligan a migrar a los habitantes sin capacidad de pago (López, 2010). En Chile la gentrificación ha sido más compleja que un movimiento de desalojo de clases trabajadoras que son reemplazadas por clases medias y altas que ponen de moda barrios obreros o populares, pero igualmente se debe reconocer el aburguesamiento visible en la recuperación de barrios como Bellas Artes y Lastarria.

Estudios de barrios renovados (López, Arriagada y otros, 2013) muestran que los vecinos antiguos destacan fuertemente las ventajas de conectividad y que se reflejan no solamente en una mayor accesibilidad relativa a servicios y transporte. La tranquilidad, seguridad y buenas relaciones con vecinos/as. Los procesos de renovación urbana traen efectos de congestión, grandes conos de sombra sobre las casas de vecinos antiguos. La Encuesta del Estudio de López (Arriagada y otros, 2013) preguntó a los vecinos antiguos si hubo mejoras producto de la llegada de hogares de mayores ingresos y si bien reconocen la llegada 
de restaurantes y comercios nuevos (estos son bienes privados), no perciben que haya mejoras de equipamientos colectivos (Bienes Públicos) y, claramente, perciben que la calidad de vida ofrecida por el barrio se ha deteriorado.

Wacquant (2008) destacaba que los procesos recientes de arribo de proyectos de clase media se acompañan de expulsiones de habitantes de barrios obreros en declive mientras el Estado gira suspolíticas de apoyar a las clases bajas, a favorecer servicios y equipamientos y se instala un redesarrollo urbano que segrega de un modo diferente ya que evapora la estructura urbana industrial y promueve la fragmentación por proyectos inmobiliarios.

Respecto al concepto de fragmentación, Batty (2005) lo define como usos de suelo en forma de archipiélago en lo social, físico y simbólico que responden a demandas ajenas a la colectividad local.

Sus efectos son la pérdida de coherencia y singularización de espacios cerrados, (Vidal Rojas, 1997), con un efecto que deteriora la integración, y expresa formas de globalización inmobiliaria y cambios de la estructura urbana (Prevot Schapira y Cattaneo, 2008).

\section{Metodología}

En este trabajo se estudia la trayectoria urbana de nuevos residentes del centro, en especial, de individuos instalados en grandes torres de departamentos versus nuevos residentes que ocupa mercados secundarios de viviendas obreras y patrimoniales. La fuente de datos son estudios recientes del repoblamiento desarrollados por la SECPLAN del Municipio como parte de los estudios del PLADECO iniciados por la Alcaldesa, 2013-2016, Carolina Tohá. Se usan datos del Censo, Permisos de Edificación, Encuesta CASEN y datos de una encuesta a 720 hogares, representativa por tipos de viviendas aplicadas a nuevos residentes en el marco del 
Convenio SURPLAN/IMS (2014), siendo jefe de proyecto e investigador principal Camilo Arriagada L., y coinvestigadores José M. Cortinez, Marjolaine Nelly, Gino Bayley, Alejandro Gana y Valeria Catafau. La contraparte del IMS fue Mauricio Valenzuela y Pamela Castro de SECPLAN. En particular los procesamientos de datos de la Encuesta SURPLAN fueron realizados por Alejandro Gana y de las entrevistas por Gino Bayley.

\section{Análisis y discusión de datos}

El repoblamiento es el proceso inducido de localización de vivienda y consiguientemente de nuevos habitantes en el centro de Santiago a contar de 1990, por iniciativa municipal y que contó con los incentivos de financiamiento extraordinario del Subsidio de Renovación Urbana, de la gestión inmobiliaria de la CORDESAN de transferencia de suelos y coordinación con el sector inmobiliario y de un sistema normativo de planificación urbana liberalizado al extremo en la administración comunal final del período de dictadura. Si bien este proceso se inicia como una política pública que genera proyectos desde 1991 va a explotar después del 2000 como negocio inmobiliario privado de gran escala y con una dinámica autónoma rentable. Este fenómeno combina una creciente demanda por vivienda económica cercana a fuentes de empleo y estudio, junto con el desarrollo franco de una oferta inmobiliaria especializada en altura, densidad y unidades de pocos dormitorios y superficie por piso, facilitado por la oferta de los sitios eriazos disponibles en la comuna.

Entre 1990 y 2013, se emiten casi 120 mil permisos de edificación de vivienda, desde una nula actividad comunal (253 permisos a fines de los ochenta) hasta un lapso de tres años bordeando los 45 mil permisos (2006-2008) llegando al récord absoluto de permisos el año 2008 (17.141 
que fue un 30\% del total RM). Entre 2009-2013, las cifras oscilan en un rango de 1.900 a 6.500 permisos. Fruto de este cambio la comuna quiebra todas las proyecciones y transforma, según los datos del precenso, a la comuna como foco de mayor construcción de la región 2002-2011. Los datos provisorios del Censo 2012 indicaban que la comuna crece de 185 a más de 310 mil habitantes entre 2002-2012. (Cuadros siguientes).

\section{Cuadro 1. Permisos de Edificación Comuna de Santiago Área Metropolitana 1988-2013}

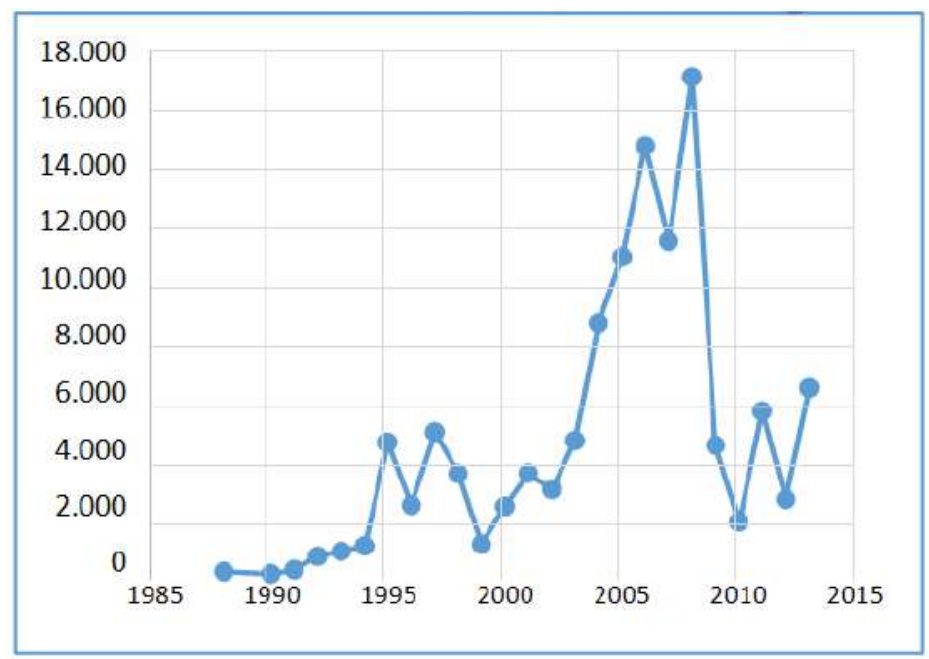

Fuente: elaboración propia con base en permisos INE. 
Cuadro 2. Estimación de Parque Habitacional Acumulado por Año Comuna de Santiago 1992-2013

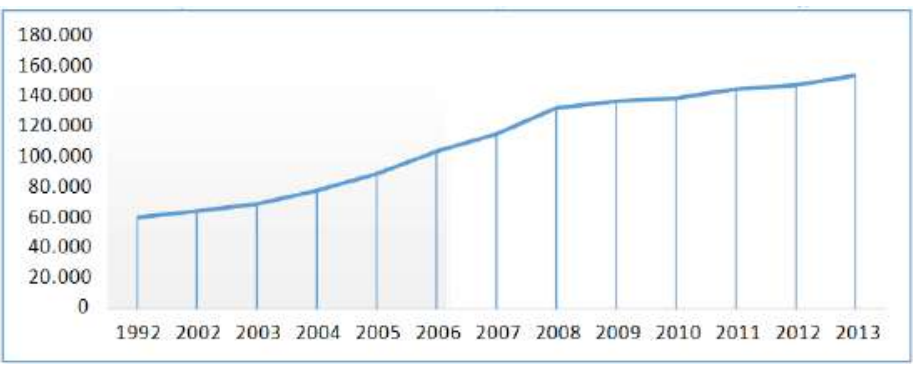

Fuente: elaboración propia con Censos 1992, 2002 y Permisos INE.

El cuadro siguiente sintetiza el perfil de residentes emergente de la comuna, el cual se diferencia del promedio de la urbe (AMGS) en varios indicadores demográficos, familiares, parentales y culturales "modernizados", similar a lo descrito para urbes OCDE en la introducción. Los hogares residentes en Santiago experimentan un alza al $70 \%$ de hogares con Internet muy superior a la ciudad en igual período. Las viviendas arrendadas eran elevadas al año 2006 y la vivienda en propiedad disminuye mucho comparado al promedio de la RM. El perfil familiar es peculiar por la sobre representación sistemática de hogares unipersonales.

Cuadro 3. Revisión de índices de Internet, Arriendo, Cohabitación 1991-2001-2011

\begin{tabular}{|c|c|c|c|c|c|}
\hline 2000 & $\begin{array}{c}\text { Usa } \\
\text { Internet }\end{array}$ & $\begin{array}{c}\text { Viv. } \\
\text { propia }\end{array}$ & $\begin{array}{c}\text { Viv. } \\
\text { arrendada }\end{array}$ & $\begin{array}{c}\text { Hogar } \\
\text { unipersonal }\end{array}$ & Conviven \\
\hline SANTIAGO & $13 \%$ & $38 \%$ & $55 \%$ & $22 \%$ & $14 \%$ \\
\hline AMGS & $13 \%$ & $70 \%$ & $20 \%$ & $8 \%$ & $11 \%$ \\
\hline Diferencial & $0 \%$ & $-32 \%$ & $34 \%$ & $14 \%$ & $3 \%$ \\
\hline
\end{tabular}




\begin{tabular}{|c|c|c|c|c|c|}
\hline 2006 & $\begin{array}{c}\text { Usa } \\
\text { Internet }\end{array}$ & $\begin{array}{c}\text { Viv. } \\
\text { propia }\end{array}$ & $\begin{array}{c}\text { Viv. } \\
\text { arrendada }\end{array}$ & $\begin{array}{c}\text { Hogar } \\
\text { unipersonal }\end{array}$ & conviven \\
\hline SANTIAGO & $58 \%$ & $34 \%$ & $53 \%$ & $24 \%$ & $18 \%$ \\
\hline AMGS & $67 \%$ & $67 \%$ & $21 \%$ & $8 \%$ & $14 \%$ \\
\hline Diferencial & $-8 \%$ & $-34 \%$ & $32 \%$ & $15 \%$ & $4 \%$ \\
\hline 2011 & $\begin{array}{c}\text { Usa } \\
\text { Internet }\end{array}$ & $\begin{array}{c}\text { Viv. } \\
\text { propia }\end{array}$ & $\begin{array}{c}\text { Viv. } \\
\text { arrendada }\end{array}$ & $\begin{array}{c}\text { Hogar } \\
\text { unipersonal }\end{array}$ & conviven \\
\hline SANTIAGO & $70 \%$ & $43 \%$ & $50 \%$ & $26 \%$ & $18 \%$ \\
\hline AMGS & $51 \%$ & $63 \%$ & $21 \%$ & $12 \%$ & $14 \%$ \\
\hline Diferencial & $20 \%$ & $-20 \%$ & $29 \%$ & $14 \%$ & $4 \%$ \\
\hline
\end{tabular}

Fuente: elaboración propia con datos de la Encuestas CASEN.

El censo 2012 muestra que un 70\% de los nuevos residentes (5 años o menos en la comuna) arriendan, mientras que, el grupo con más años de residencia la moda es un $50 \%$ de propietarios y el arriendo es el 42\%. En términos absolutos 90 mil nuevos residentes llegan a la comuna arrendando su vivienda mientras que otros 35 mil llegan a viviendas compradas. Hay que destacar que en la RM lo usual ha sido el acceso a la vivienda en régimen de propiedad por lo cual este boom del arrendamiento que acompaño al repoblamiento de la comuna central marca un doble cambio: de localización y de régimen de tenencia, fenómeno que ya se destacó se replica en los centros de urbes de la OCDE.

Cuadro 4. Situación actual de ocupación de la vivienda por Lugar de Origen 5 años antes

\begin{tabular}{|c|c|c|c|c|}
\hline $\begin{array}{c}\text { Origen por } \\
\text { Tenencia }\end{array}$ & $\begin{array}{c}\text { Vivienda } \\
\text { Propia }\end{array}$ & Arrendada & Otra & Total \\
\hline $\begin{array}{c}\text { Residente } \\
\text { Antiguo }\end{array}$ & $49,00 \%$ & $41,90 \%$ & $9,10 \%$ & $100 \%$ \\
\hline
\end{tabular}




\begin{tabular}{|c|c|c|c|c|}
\hline $\begin{array}{c}\text { Residente } \\
\text { Nuevo }\end{array}$ & $27,30 \%$ & $69,40 \%$ & $3,30 \%$ & $100 \%$ \\
\hline Total & $38,90 \%$ & $54,70 \%$ & $6,40 \%$ & $100 \%$ \\
\hline $\begin{array}{c}\text { N Residente } \\
\text { Nuevo }\end{array}$ & 35.497 & 90.103 & 4.305 & 129.905 \\
\hline
\end{tabular}

Fuente: SURPLAN/IMS (2014) con base en INE.

Los datos de CASEN 2006-2011 muestran tres tendencias dominantes: viviendas arrendadas por nuevos residentes en primer lugar; segundo, hay movilidad habitacional de residentes antiguos a comprar vivienda nueva, y solo en tercer lugar hay nuevos residentes que llegan comprando. Asimismo es llamativo que aumentaron las personas en otra situación, cesión, uso irregular, etc., entre 2006 y 2011. Hay que aclarar que el fuerte aumento de stock del repoblamiento 2002-2012 atrae compradores de las nuevas viviendas que compran las viviendas para arrendarlas.

Cuadro 5. CASEN 2006-2009. Tenencia de la vivienda según Comuna Origen

\begin{tabular}{|c|c|c|c|c|}
\hline Casen 2006 & Propia & Arrendada & Otra & Total \\
\hline $\begin{array}{c}\text { Residente } \\
\text { Antiguo }\end{array}$ & $41 \%$ & $44 \%$ & $15 \%$ & $100 \%$ \\
\hline $\begin{array}{c}\text { Residente } \\
\text { Nuevo (5 } \\
\text { años) }\end{array}$ & $14 \%$ & $74 \%$ & $11 \%$ & $100 \%$ \\
\hline $\begin{array}{c}\text { Casen 2011 } \\
\begin{array}{c}\text { Residente } \\
\text { Antiguo }\end{array}\end{array}$ & Propia & Arrendada & Otra & Total \\
\hline $\begin{array}{c}\text { Residente } \\
\text { Nuevo (5 } \\
\text { años) }\end{array}$ & $26 \%$ & $39 \%$ & $10 \%$ & $100 \%$ \\
\hline
\end{tabular}

Fuente: SURPLAN/IMS (2014) con base en INE. 
Controlada la situación de tenencia anterior a llegar a vivir a Santiago, es muy interesante que la mitad de los nuevos residentes de edificios de mayor altura y un $40 \%$ de los nuevos residentes en casas antiguas eran familiares de los propietarios de la anterior vivienda, es decir que eran allegados o miembros dependientes que se han emancipado al llegar a esta vivienda en la comuna de Santiago. Ello se asocia al dato anterior de grandes tasas de jóvenes que llegan a la comuna como estudiantes universitarios o profesionales jóvenes. Una segunda situación relevante de origen previo son personas que antes arrendaban, lo que se asocia al mismo perfil y a matrimonios o parejas en fase de formación.

Cuadro 6. Tenencia de la vivienda antes de vivir en Santiago según tipo vivienda

\begin{tabular}{|c|c|c|c|c|}
\hline & Propietario & Arrendatario & $\begin{array}{c}\text { Familiar del } \\
\text { propietario }\end{array}$ & Total \\
\hline $\begin{array}{c}\text { Conventillo } \\
/ \text { Cité }\end{array}$ & $12,8 \%$ & $46,8 \%$ & $40,4 \%$ & $100,0 \%$ \\
\hline $\begin{array}{c}\text { Vivienda } \\
\text { obrera }\end{array}$ & $18,4 \%$ & $36,2 \%$ & $45,4 \%$ & $100,0 \%$ \\
\hline $\begin{array}{c}\text { Departa- } \\
\text { mento 10 o } \\
\text { más pisos }\end{array}$ & $18,8 \%$ & $31,0 \%$ & $50,2 \%$ & $100,0 \%$ \\
\hline Total & $17,1 \%$ & $37,8 \%$ & $45,1 \%$ & $100,0 \%$ \\
\hline
\end{tabular}

Fuente: SURPLAN IMS, 2014.

El repoblamiento se correlaciona con la disminución de los índices de personas por vivienda de forma muy acentuada de 3,6 a 2,9 entre 1992-2002 y a 2,1 el 2002. La reducción a un promedio de 2,1 en el último censo es mucho más rápida que la caída observada en la Región Metropolitana 
como promedio y se explica precisamente por la masiva llegada de nuevos residentes en hogares de una y dos personas jóvenes (estudiantes y profesionales) que modifican fuertemente la pirámide demográfica y cohabitación del centro siendo una pauta relevante poco evidente de las pautas de cohabitación y uso del espacio asociadas a la modernización y movilidad social generadas por el crecimiento económico chileno neoliberal de los postnoventa y procesos de mercado inmobiliario.

Hay que recordar que, en los centros de varias capitales de países desarrollados existe un cambio sociocultural que explica la sobrerepresentación de culturas juveniles, liberales, minorías sexuales, artistas, artesanos, inmigrantes y, en general, personas solas que prefieren la masividad y el anonimato propio de la gran densidad central respecto a los sistemas suburbanos estructurados para familias. Los centros de las ciudades mayores en Europa y Norte América en general han sido espacios de avanzada en la liberalización de pautas de convivencia y cambio sociodemográfico residencialmente focalizado que están descritos en una diversidad de procesos de localización de inmigrantes y trabajadores informales pobres en paralelo de procesos de gentrificación de clases ilustradas, ejecutivos jóvenes solteros, estudiantes universitarios y minorías sexuales (gaytrification).

El siguiente gráfico compara la caída del índice de personas por vivienda que acompaña al boom inmobiliario central y lo compara con la tendencia de la RM y de países OCDE mostrando la importancia de profundizar quiénes son los nuevos residentes y los efectos de su llegada en los barrios centrales. 
Cuadro 7. Evolución índice personas por vivienda. Comuna Santiago y países OCDE en segunda transición demográfica

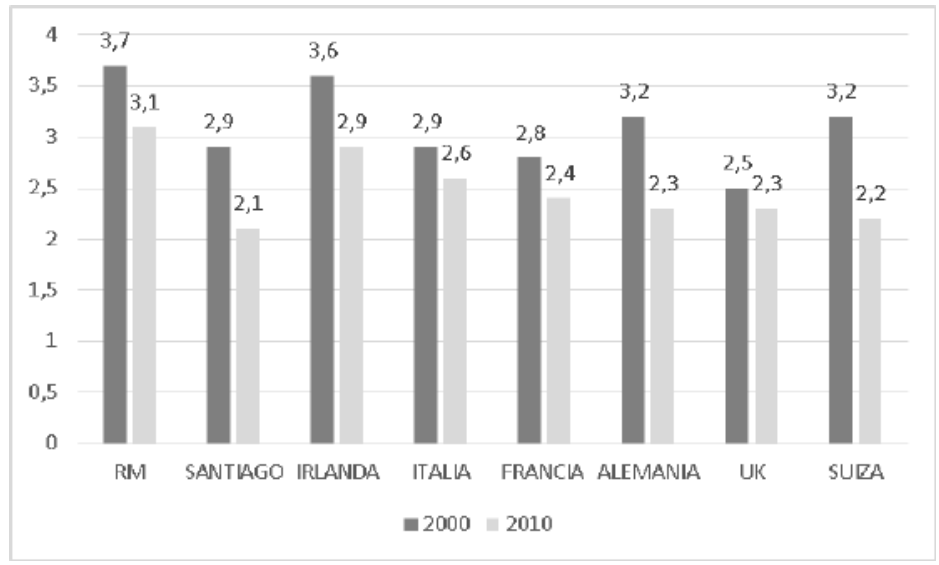

Fuente: SURPLAN/IMS base en Eurostat e INE.

La pirámide de edades de residentes muestra en pocos años transformaciones importantes. Mientras en 1992 Santiago reportaba una pirámide semejante al Gran Santiago (AMGS) que se diferenciaba por un perfil más envejecido, al 2012 hay un recambio de población por el cual muchos residentes emigraron a la periferia y un número importante de nuevos residentes llegó a los departamentos y se asocia al salto de jóvenes y adultos-jóvenes (25-29, 20-24 y 30-34). La expansión 1992-2002 de las edades intermedias jóvenes de 20 a 29 años es mayor entre los hombres que entre las mujeres. (Arriagada y otros, 2008, MINVU).

Los resultados del Censo 2012 después de que ocurre el cambio intercensal confirman la mayoría de jóvenes y reducción del grupo en edad escolar y tercera edad respecto de la pirámide general de la comuna 2002. 
Cuadro 8. Estructura por sexo y edad. Población comuna de Santiago, Censo 2012

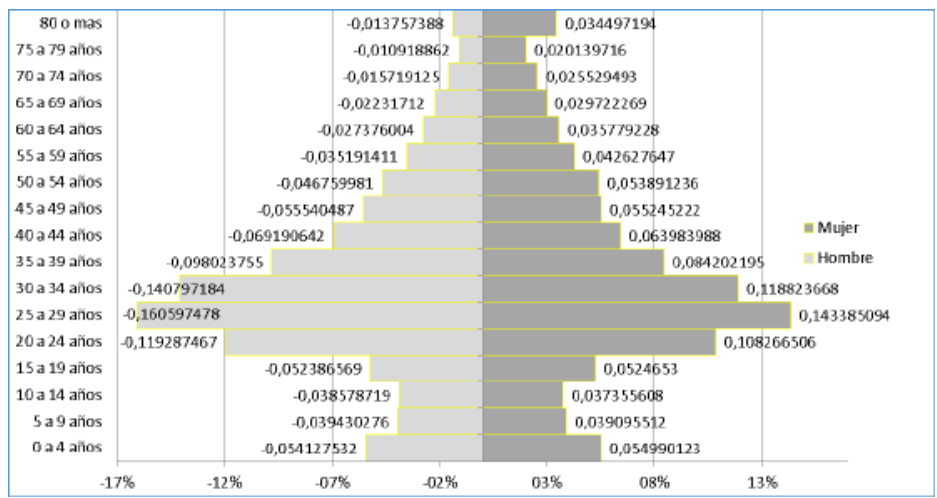

Cuadro 9. Estructura por sexo y edad de la Población de Nuevos Residentes 2007-2012

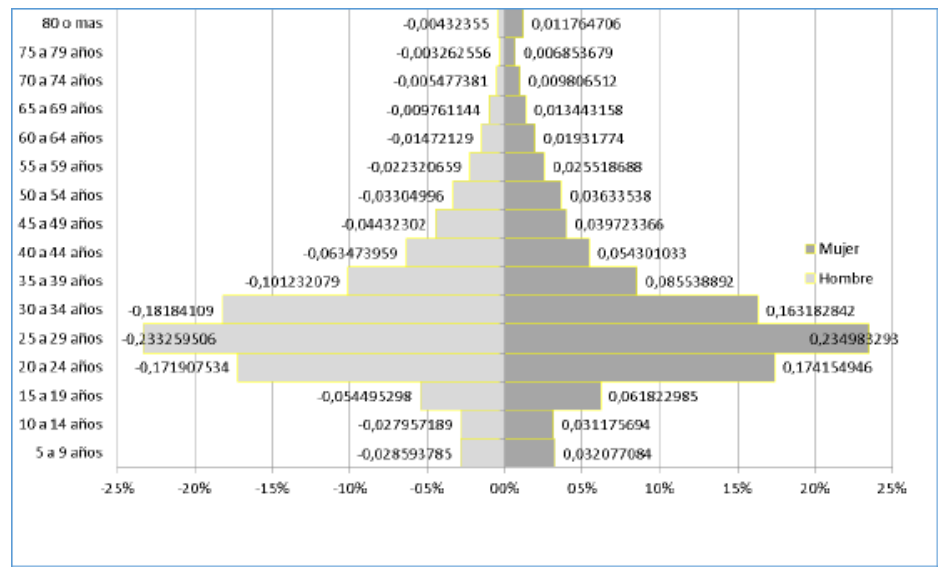

Fuente: SURPLAN-IMS con base en CPV 2012. 
La comuna de Santiago recibió población de mayores ingresos fuertemente. Según la encuesta CASEN 2006 y 2011 los habitantes recientes son aquellos que aumentaron más el ingreso entre 2006 y 2011. Los recién llegados de los últimos 5 años tienen un ingreso un 53\% mayor que los recién llegados entre 2001 y 2006. Mientras que los hogares de más de 5 años en la comuna también aumentaron su ingresos pero en mucho menor medida $(26,5 \%)$ siendo que su localización es la misma que los nuevos recién llegados. El aumento del nivel de ingresos de la población permanente en $26 \%$ entre 2006 y 2011 también se puede relacionar con la llegada de nuevos habitantes.

Cuadro 10. Cambio del promedio de ingreso por tipo de residente, comuna de Santiago

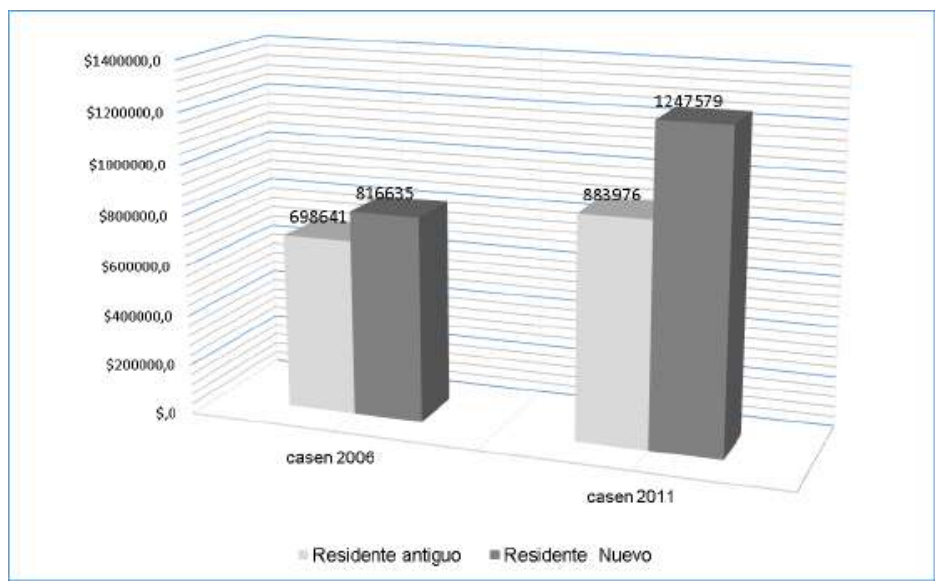

Al 2011, la población migrante reciente, esto es, llegada en los últimos años, se concentra en gran medida en los dos quintiles de mayores ingresos. Respecto a la población permanente o de residencia mayor a 5 años, hay que considerar que los puntos de corte de los quintiles nacional han variado entre las mediciones 2006 y 2011 afectando 
magnitudes relativas de uno y otro quintil. En este sentido, el quintil que en mayor medida se ha consolidado en la comuna de Santiago es el 4, de ingreso medio alto, aumentando de $25 \%$ a $31 \%$. El quintil 5, el mayor proporcionalmente en la comuna, disminuye entre las mediciones en la población permanente.

Cuadro 11. Distribución ingreso autónomo hogar según residencia 5 años antes, 2006 y $2011 \%$ fila

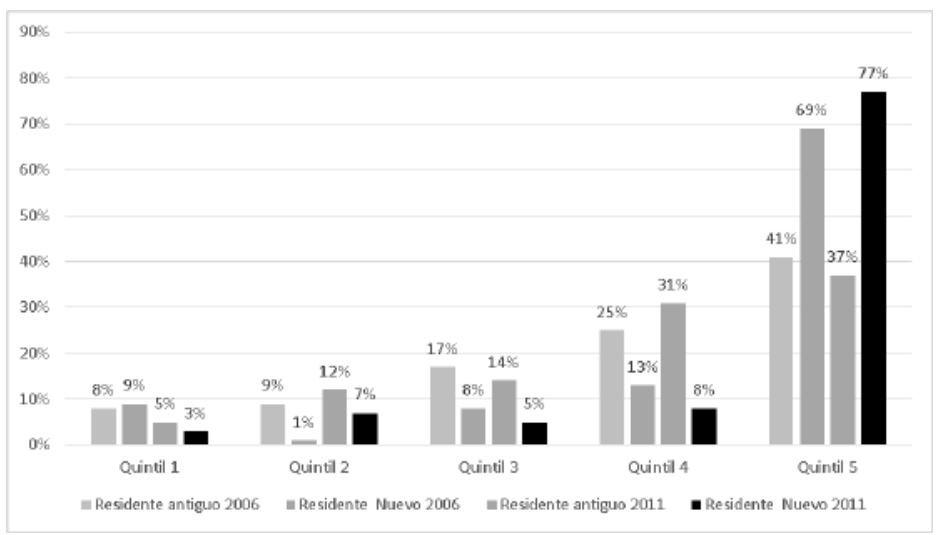

Fuente: SURPLAN/IMS con base en CASEN.

En el año 2014 se levantaron 720 Encuestas SURPLAN/IMS segmentadas por tipos de viviendas en una gama de cinco categorías: departamentos de gran altura, departamentos antiguos, casas, conventillos-cites y piezas en casas antiguas. Las encuestas fueron aplicadas exclusivamente a nuevos residentes (que se cambiaron de comuna desde 1990, o bien que accedieron a su primera vivienda desde la comuna). En este análisis se han seleccionado tres segmentos: viviendas de renovación urbana de gran altura (233 casos) versus dos tipos de 
alojamientos en extensión patrimoniales: conventillos y cites y viviendas obreras, esto es, unidades patrimoniales (256 casos conjuntamente).

En efecto el arraigo comunal se pudo discriminar preguntando si los residentes actuales se perciben como habitantes temporales o de largo plazo. Entre los habitantes de edificios de 10 y más pisos se encuentra el mayor porcentaje de residentes temporales $(20,4 \%)$ mientras los habitantes de vivienda obrera, según su autopercepción, figuran como los más estables (70\%).

Hay que destacar que los nuevos residentes de la comuna atraídos por el repoblamiento están divididos en dos grupos a la hora de proyectarse a futuro como residentes permanentes o de paso. En los departamentos de mayor altura la mitad de los nuevos residentes se proyecta al largo plazo en la comuna y otra mitad planea mudarse. En el caso de los nuevos residentes emplazados en viviendas obreras o cites-pasajes, el porcentaje de residentes transitorios se reduce al 30 y $40 \%$ de los encuestados y crece el porcentaje con proyección vecinal de largo plazo. El proyecto de cambio de los residentes de departamentos se trata de planes de irse a otra comuna (posiblemente volver a la comuna desde donde vienen), mientras que los residentes transitorios de viviendas patrimoniales hablan más de moverse a una vivienda más grande u otro barrio de la comuna de Santiago.

Este dilema es importante ya que significa que las torres nuevas pobladas de hogares unipersonales con planes, uno de cada dos, de mudarse hacen compleja la mantención de los edificios y la constitución de comunidades en los barrios, base de la vitalidad de los barrios y estilos de convivencia en los entornos. Este cambio es una parte de raíz generacional ya que los jóvenes no se proyectan por muchos años en varios frentes, pero por otro tiene que ver con el modelo o producto habitacional que no está pensado en términos de su impacto 
comunitario y urbano. Si es positivo que viviendas hasta hace poco muy desvalorizadas como son los cites y pasajes y las viviendas obreras sean fuente de expectativas mayoritarias de residencia permanente en la comuna.

Cuadro 12. Usted se autodefine como un residente temporal o de largo plazo en la comuna

\begin{tabular}{|c|c|c|c|}
\hline & $\begin{array}{c}\text { Residente } \\
\text { Temporal,ñ } \\
\text { más de 2 años }\end{array}$ & $\begin{array}{c}\text { Un residente } \\
\text { porno más de } \\
5-7 \text { años }\end{array}$ & $\begin{array}{c}\text { Un residente } \\
\text { porlargo tiempo, } \\
\text { más de5-7 años }\end{array}$ \\
\hline $\begin{array}{c}\text { Conventillo / } \\
\text { Cité }\end{array}$ & $15,2 \%$ & $26,1 \%$ & $58,7 \%$ \\
\hline Vivienda obrera & $9,3 \%$ & $21,6 \%$ & $69,1 \%$ \\
\hline $\begin{array}{c}\text { Departamento } \\
10 \text { o más pisos }\end{array}$ & $20,4 \%$ & $28,7 \%$ & $50,9 \%$ \\
\hline
\end{tabular}

Fuente: encuesta SURPLAN, 2014.

Ante la pregunta “¿Por qué razones eligió vivir aquí?”, los diferentes tipos de residentes coinciden en que valoran la localización central y la conectividad fundamentalmente, la cercanía al trabajo y estudio, lo que es muy importante en los residentes de departamentos, mientras que la cercanía con redes familiares y el barrio, que igualmente es un atributo propio de zonas centrales históricas, es una preferencia que aumenta entre los nuevos residentes de vivienda obrera y en conventillos. Claramente esto explica las diferencias sociales que muestran los datos de ingreso y, asimismo, se relacionan con la diferente proyección de futuro en el barrio, mayor entre los habitantes de viviendas patrimoniales. 
Cuadro 13. Primera causa declarada de llegar a vivir al centro

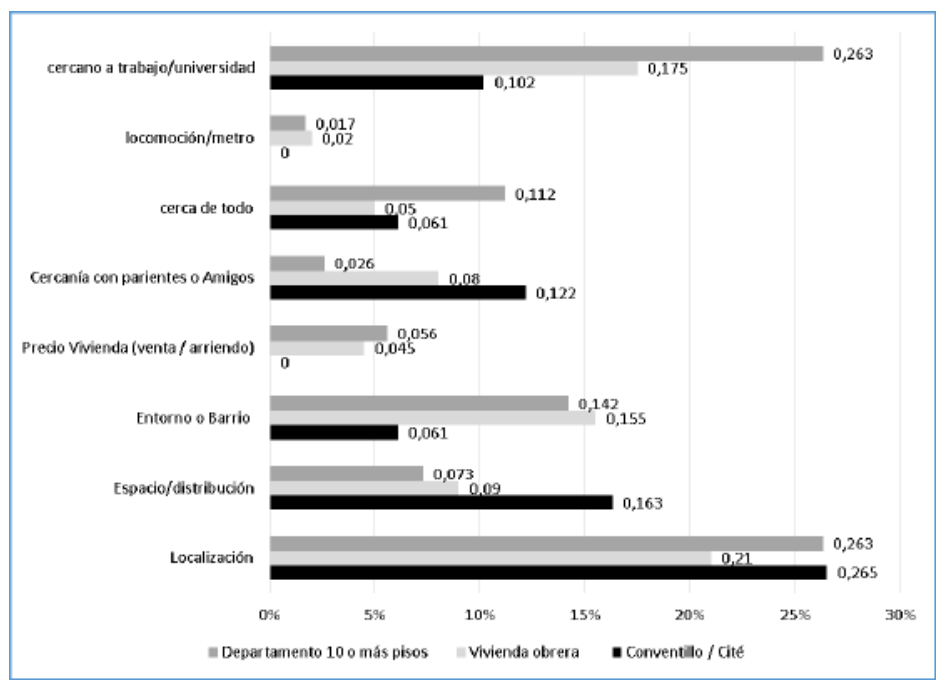

Fuente: elaboración propia con datos SURPLAN/IMS.

El siguiente gráfico permite controlar la vulnerabilidad declarada respecto a conflictos en el uso del espacio público, incivilidades y directamente delitos, mostrando la mayor exposición de las viviendas en extensión versus los departamentos en altura que viven más aislados de los problemas de la calle. Los riesgos de asaltos son mayores en la vivienda obrera, que es de los tres casos la tipología más integrada a la calle y espacio urbano. 
Cuadro 14. ¿Por vivir en este barrio se ha visto expuesto a alguna de las siguientes situaciones?

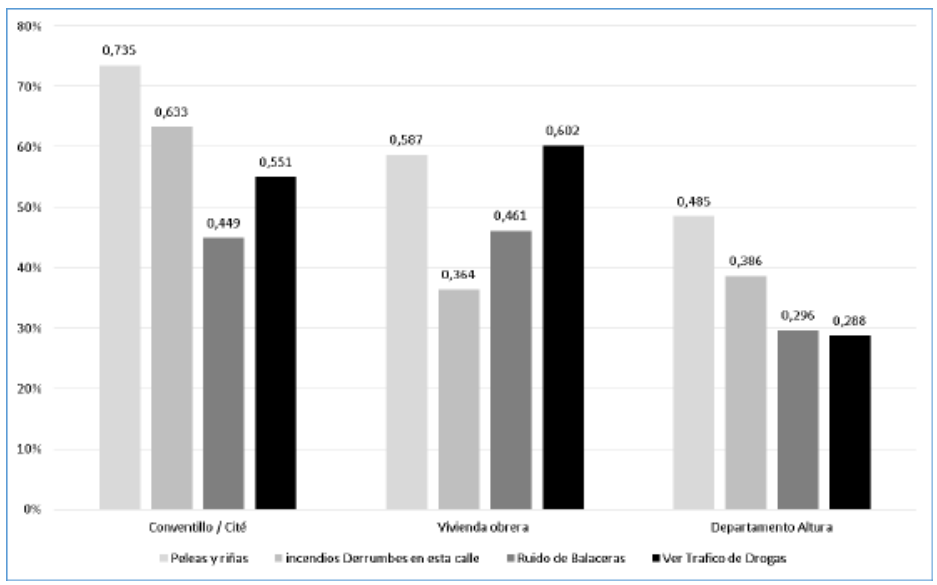

Fuente: SURPLAN/IMS (2014).

Consultados a futuro acerca de cuáles viviendas se debiera fomentar cerca de un $90 \%$ de los nuevos residentes encuestados piensa que la mejor opción de vivienda a promover en la comuna de Santiago es restaurar viviendas patrimoniales y construir departamentos de altura moderada, lo que es declarado incluso por quienes viven a mayor altura hoy. 
Cuadro 15. De los siguientes tipos de vivienda, ¿cuáles se debería fomentar en la comuna?

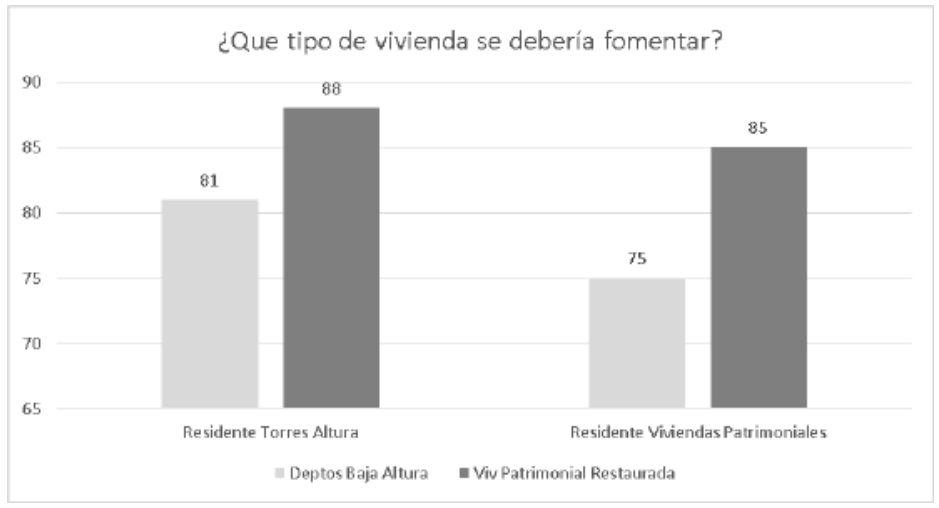

Fuente: SURPLAN/IMS (2013).

Llama la atención que, en las viviendas priorizadas a desarrollar, se hace alusión a viviendas patrimoniales restauradas, lo que a la fecha del estudio era un área donde existía vacío de oferta de instrumentos y atribuciones necesarias para la rehabilitación de inmuebles patrimoniales deteriorados. Respecto a esto, precisamente en el año 2016, el Municipio de Santiago a cargo de la Alcaldesa Carolina Tohá en conjunto con la SUBDERE (Subsecretaría de Desarrollo Regional) y el BID (Banco Interamericano de Desarrollo) lograron diseñar y tramitar un proyecto piloto de Recuperación de Barrios Patrimoniales de Portales y Matta Oriente, destinado a recuperar y subdividir casonas para fines de vivienda social, nuevos comercios y centros culturales adosados, además de intervenir en los espacios públicos. 


\section{Conclusiones}

El nuevo auge de crecimiento demográfico de los centros es un fenómeno internacional que incorpora grandes oportunidades pero también amenazas, y muy fundamentalmente demanda conocimiento de tendencias de cambio y problemas emergentes, para los cuales se requieren regulaciones como también políticas públicas innovadoras.

La nueva demanda por centralidad y por espacio público que caracteriza las preferencias de localización de los hogares post año 2000, junto con la inversión inmobiliaria que ha priorizado proyectos de renovación urbana en altura bien conectados a la ciudad, han dejado en el pasado el problema del despoblamiento del centro, pero este cambio se ha materializado bajo modalidades de desarrollo no sostenibles debido a que se caracteriza por grandes rentas privadas basadas en la captura de plusvalías creadas por el Estado, junto con provocar graves externalidades urbanas y sociales, y donde el derecho de los sectores modestos a permanecer en el otro se ha visto mermado y donde sus posibilidades de retención se ubican en el parque de viviendas, preexistente a la renovación urbana, todavía muy deteriorado.

El fenómeno de regreso al centro ha sido protagonizado por perfiles de población muy diferentes al usual acceso a la vivienda de familias nucleares. Destacan a nivel general tendencias de expansión del arrendamiento, el rejuvenecimiento de la pirámide de edades, la masificación de hogares de una persona y el incremento de la escolaridad e ingreso medio de los residentes. No obstante, esta tendencia general reconoce importantes segmentaciones y diferencias interiores, de una parte; $y$ de otra, la aparición de problemas locales extendidos de convivencia, interacción y fenómenos de deterioro vecinal que abren frentes nuevos y que se suman a la sobrecargada agenda urbana clásica de segregación y exclusión en los barrios periféricos. 
Antes de la renovación, el centro estaba en franco deterioro y abandono por el Estado y el mercado, y el movimiento ciudadano en pro de los barrios ha sido una reacción posterior a la renovación y no previo. La densificación del centro siempre fue un objetivo de los gobiernos de la concertación post 1990 e inspiró el diseño del subsidio de renovación urbana, pero la renovación urbana que orquestó el sector inmobiliario adoleció de regulaciones y se ha traducido en grandes torres donde caben personas solas y parejas pero no familias. Esto ha generado un negocio muy rentable pero que ha subutilizado el potencial de cabida para más personas, ha destruido viviendas y entornos patrimoniales de forma directa o vía procesos especulativos y, además, no ha aportado ni equipamientos ni áreas verdes, usufructuando los atributos urbanos previos del centro.

En muchos barrios, la renovación no está presente e igualmente existe deterioro e inseguridad. Si existe un hambre por calidad de vida de barrios, por derecho a la ciudad, por cultura y patrimonio y a diferentes facilidades y pautas de movilidad y uso del tiempo libre que son muy llamativas en la sociedad chilena post 2000, y que claramente son tendencias propias de la globalización de estilos de vida y cultura urbana y no fenómenos locales ni dependientes de la renovación urbana, esta nueva cultura o demanda urbana incluye otras facetas propias de la globalización de una nueva pobreza, como son las personas de calle, los inmigrantes hacinados en tugurios y pandillas vinculadas al microtráfico de drogas.

El contexto de políticas públicas es diferente y el municipio de Santiago ha venido innovando la política urbanística, de regeneración de barrios y de mejoramiento de viviendas patrimoniales de forma muy importante en la Administración de la Alcaldesa Carolina Tohá de cara a muchos de los fenómenos enunciados en su expresión de territorios o barrios. En efecto, el gobierno central ha estado creando programas piloto nuevos para áreas centrales a partir de la experiencia de proyectos implementados por la 
municipalidad. Se requieren claramente políticas oportunas que tengan la capacidad de moderar el recambio social o expulsión y potenciar la diversificación social o mezclas de usos y grupos sociales, que es la gran virtud del centro como destaca el libro Santiago, lugar de encuentro. En concreto se requiere entender cuáles cuadros socioterritoriales conducen a situaciones de convivencia con exclusión e individuación versus convivencia con integración y desarrollo sostenible de los barrios.

El trasfondo sociodemográfico del repoblamiento permanece abierto a profundización. Las diferencias entre residentes antiguos y nuevos son muy claras, sobre todo, desde el punto de vista de su ingreso, capital cultural y propensión a residir, y son parte de lo que mejor se percibe del cambio de Santiago. Mucho menos conocidas son las diferencias internas o subgrupos de nuevos residentes con sus problemáticas y proyecciones en el desarrollo del centro urbano mayor. Se trata de situaciones donde la oferta de servicios sociales y proyectos innovadores pueden modificar la forma en que la comuna acoge e integra al universo de residentes diferentes que se ha descrito en este trabajo.

\section{Bibliografía}

Arriagada, Camilo (2016). Barrios centrales emergentes y discriminación de los inmigrantes minorías visibles. Reflexiones a partir del Estudio de los comercios urbanos y la vida de barrio en Valparaíso, Santiago e Iquique. En María Emilia Tijoux (ed.), Racismo en Chile. Santiago de Chile: Estudios.

Arriagada, Camilo, (ed.) (2014). Inmigrantes internacionales: emprendimiento en barrios comerciales de Iquique, Gran Valparaíso y Santiago de chile. Santiago de Chile: FAU, U. de ChileCEIBO editores. 
Arriagada, Camilo, Juan Moreno y Enrique Cartier (2007). Evaluación de impacto del Subsidio de Renovación Urbana en el Área Metropolitana del Gran Santiago (1991-2006), División Técnica de Estudio y Fomento Habitacional, Ministerio de Vivienda y Urbanismo Chile.

Arriagada, Camilo y Daniela Simioni (2001). Dinámica de valorización del suelo en el Área Metropolitana del Gran Santiago y desafíos del financiamiento metropolitano. Serie Medio Ambiente y Desarrollo, N. ${ }^{\circ} 44$, Comisión Económica para América Latina y el Caribe, CEPAL (www.eclac.cl).

Arriagada, Camilo y Jorge Rodríguez (2003). Segregación residencial en áreas metropolitanas de América Latina: magnitud, características, evolución, e implicaciones de política. Serie Población y Desarrollo, N. ${ }^{\circ}$ 47, CEPAL (www.eclac.cl).

Arriagada, Camilo (2009). Segregación residencial en tiempos de ciudades globales: estudio comparado áreas metropolitanas Chile y Canadá.

Batty, Michael (2005). Cities and Complexity: Understanding Cities with Celular Auto mata, agents Based Models, and Fractals. Cambridge Massachusetts: MIT Press.

Bauman Zygmunt (2000). Miedo líquido: la sociedad contemporánea y sus temores. Barcelona: Paidós.

Bauman, Zygmunt (2002). La sociedad sitiada. Buenos Aires: FCE.

Butler, Tim (s/f). Gentrification and Globalization: the emergence of a middle range theory?, Cahier Ville, European Comission (2013). Quality of Life in Cities, Regional and Urban Policy CEE, EUROSTAT. European Comission (2010). Second State of european city Report, DG Regional Policy.

Hutton, Tom \& Ronan Padison, Editors (2006). Trajectories of the New Economy: An International Investigation of Inner City Regeneration and Dislocations. Canada, University of British Columbia, Vancouver. 
Insulza, Jorge (2011). Latino-gentrification? Focusing on physical and socio economic patterns of change in Latin American Inner Cities. Londres: Urban Studies.

Jacobs, Jane (1961). Muerte y vida de las grandes ciudades americanas. España: Colección Entre Líneas.

Lopez, Ernesto (2010). Gentrification by Ground Rent Dispossession: The Shadows Cast by Large - Scale Urban Renewal in Santiago de Chile. International Journal of Urban and Regional Research, Oxford UK.

Kaztman, Rubén (2001). Seducidos y abandonados: el aislamiento social de los pobres urbanos. Revista de la CEPAL, No 75, pp. 171-189, Santiago de Chile.

Katzman, R. (ed.) (1999). Activos y estructuras de oportunidades. Estudios sobre las raíces de la vulnerabilidad social en el Uruguay. Montevideo: PNUD y CEPAL, LC/MVD/R.180.

López Morales, Ernesto, Camilo Arriagada Luco, Daniel, Ivo Gasic (2013). Encuesta a vecinos de proyectos de renovacion urbana amigos (documento del seminario FAU, 29 de agosto de 2013).

Musco, Francesco (2009). Rigeneraziones Urbana e Sostenibilita, Studi Urbani e regionali. Milano, Italy: Franco Angeli SRL.

Marquez, Francisca (ed.) (2012). Ciudades de Georg Simmel: Lecturas contemporáneas. Colección sociología, Personas, Organización, Sociedad, Universidad Alberto Hurtado, Doctorado en Arquitectura y Estudios Urbanos, Consejo de las Cultura y las Artes, Santiago de Chile.

Navez Bouchanine, Francoise (2002). La fragmentation en question: des villes entre fragmentation spatiale et fragmentation sociale. París: L. Harmatton.

Prevot Schapira Mare France y Rodrigo Cattaneo (2008). Buenos Aires: la fragmentación en los interticios de una sociedad polarizada. Revista EURE, vol. XXXIV, N.o 103, pp. 73-92, diciembre, Santiago de Chile.

Poduje, Ivan, Juan Martínez, Juan Santa Cruz, Nicolás Jobet (2015). Infilling: cómo cambió Santiago y nuestra forma de vivir la ciudad. Almagro, Atisba, Socovesa, Santiago de Chile. 
SECPLAN-IMS (2015). Santiago, lugar de encuentro. Municipalidad de Santiago.

United States Department of Housing and Urban Development, SOCDS Census and American Community Survay Data, USA. https://bit.ly/2XuycX1, consultado en noviembre de 2010.

Wacquant, Loui (2007). Territorial Stigmatization in the age of the Advanced Marginality. Thesis Eleven, No 91, pp. 66-77, LA/Londres.

Vieira, Elvis, Gabriela Ito, Tatiana Ashino, Laura Yamamoto, Tamie Deno (2014). Análisis del diseño urbano contemporáneo. Revista AUS, 15, Chile, pp.9-15.

Vidal Rojas, Rodrigo (1997). Metrópolis en recomposición: Elementos para una teoría de la fragmentación urbana, https://bit.ly/2QPoKeo. 



\title{
La producción social del hábitat en condiciones de precariedad socio-urbano-habitacional
}

\author{
Un estudio sobre el acceso diferencial \\ al hábitat en un asentamiento irregular \\ del oeste montevideano
}

\author{
VALENTín TRINIDAD DOS SANTOS
}

\section{Resumen}

Por medio de este estudio, se pretende abordar la producción social del hábitat en condiciones de precariedad socio-urbano-habitacional. Concretamente, desarrollar un estudio que permita comprender el proceso que transita la población excluida del acceso al mercado formal de suelo urbano - por ser una demanda económicamente no solvente-, no teniendo otra opción que residir en un asentamiento irregular (caso de estudio: COTRAVI).

En este sentido, se avanza en la descripción de las lógicas de producción y reproducción de la ciudad que han incidido en este asentamiento irregular de la zona oeste de Montevideo, tomando como referencia algunos de los aportes conceptuales de varios autores, entre ellos, Abramo, referidos a la producción de la estructura urbana en las ciudades latinoamericanas en las últimas décadas (Abramo, 2012, p. 36).

Al respecto, corresponde explicitar que la producción de las ciudades latinoamericanas han sido el resultado del funcionamiento y conjunción de tres lógicas de coordina- 
ción social: mercado, Estado, y la lógica de la necesidad. Esta última se constituye a partir de un conjunto de acciones individuales y colectivas que promueven la producción de lo que se ha de denominar "ciudades populares". Espacios de la ciudad, marcadas por condiciones de precariedad socio-urbano- habitacional (Trinidad, 2012).

Retomando el objeto de estudio, se abordará la praxis desarrollada colectivamente por parte de los residentes de COTRAVI en el marco de la producción social de su hábitat; así como de sus prácticas y discursos cotidianos, que conllevan a la materialización de una estructura socioespacial fraccionada al interior de la urbanización informal. Consolidando, barreras sociales y simbólicas, construidas a partir de los discursos y prácticas efectuadas cotidianamente, por parte de los grupos poblaciones que habitan el mismo espacio ("los de arriba" y "los de la Cañada"); así como la temporalidad de sus trayectorias socioeconómico habitacionales.

Para tales efectos, se apela a la utilización de técnicas de índole cualitativa; el proceso sociohistórico del asentamiento COTRAVI es reconstruido a partir de las entrevistas en profundidad (grupales in situ y entrevistas individuales) realizadas en el marco del Proyecto de Mejoramiento Barrial (2014-2016) PMB-MVOTMA, a vecinas/os del asentamiento que permitan acceder a los discursos de los residentes originarios y de los actuales recientes en el asentamiento.

En suma, a través de este estudio, además de profundizar en los procesos de producción social del hábitat en condiciones de precariedad socio-habitacional; también, se propone abordar los procesos de segregación en el hábitat informal, que a priori en un territorio ya segregado, dan cuenta de procesos de diferenciación, que generan barreras (in)visibles, con fuertes expresiones de estigmatización. Conllevando a que los mencionados procesos impacten 
en la sociabilidad y vínculos interpersonales, exacerbando los proyectos individuales y debilitando las capacidades de construcción de lo colectivo en COTRAVI.

\section{Palabras clave}

Producción social del hábitat, precariedad sócio-urbanohabitacional; hábitat informal.

\section{Introducción}

Por medio de este estudio ${ }^{1}$ se pretende abordar las formas del acceso diferencial al hábitat en contextos de precariedad socio-urbano-habitacional (PSUH). Concretamente, comprender los motivos por medio de los cuales, los residentes de un asentamiento irregular (COTRAVI), a través de su praxis cotidiana de producción social del hábitat (en adelante PSH), así como de sus prácticas y discursos cotidianos, conducen al desarrollo de una estructura socio-espacial fraccionada al interior de la urbanización informal. Materializado este proceso en las barreras sociales y simbólicas construidas a partir de los discursos y prácticas efectuadas cotidianamente por parte de los grupos poblaciones que habitan el mismo espacio ("los de arriba" y "los de la Cañada"), así como en la temporalidad de sus trayectorias socioeconómico habitacionales.

Para tales efectos, se retomarán los aportes Elías y Scotson (2000), a través de su propuesta, desde la sociología figuracional de establecidos-outsiders; la presente selección se considera pertinente y/o adecuada para el abordaje del mencionado tema de estudio. En el entendido, que las

1 El presente estudio es resultado de las exigencias curriculares de la asignatura "Sujetos Colectivos, Campo Popular y Hábitat" en el marco del Diploma de Estudios Urbanos e Intervenciones Territoriales. Departamento de Trabajo Social - Facultad de Ciencias Sociales - Universidad de la República. 
condiciones y temporalidades diferenciales en las que se produce en el proceso del acceso al habitar, nos permiten comprender con mayor profundidad los procesos de distinción espacial que los grupos que habitan un mismo territorio o unidad espacial desarrollan, así como las correspondientes clasificaciones y categorías sociales para distinguirse y a la vez relacionarse.

A partir de lo expuesto, se problematizará los mencionados fenómenos, que se encuentran naturalizados en el cotidiano de la población residente en el asentamiento irregular COTRAVI (Montevideo).

Por último, se entendió conveniente seleccionar este asentamiento irregular como objeto de estudio, por un lado, debido a que alberga los mencionados procesos, dimensiones y problemáticas que se constituyen centro de interés del presente estudio; por otro, debido a que quien suscribe sedesempeñó profesionalmente en el Equipo Técnico encargado de desarrollar la Formulación del Proyecto de Mejoramiento Barrial Integral del Asentamiento Irregular de referencia.

\section{Aspectos metodológicos}

El presente estudio, de carácter exploratorio, tiene por objeto abordar las formas del acceso diferencial al hábitat en contextos de precariedad socio-urbano-habitacional. Al respecto, indefectiblemente surgen una serie de interrogantes de investigación: ¿cómo se construye la experiencia de habitar en contextos de PSUH?; ¿qué implicancias tiene el factor tiempo de residencia en los vínculos que se constituyen en el ámbito barrial (asentamiento)?; ¿cómo se construyen los límites materiales y simbólicos al interior de COTRAVI?; y ¿hasta qué punto estos límites, "los de arriba" y "los de la Cañada", se constituyen como fronteras 
que instituyen una estructura socio-espacial fraccionada que obstaculizan las interacciones entre ambas poblaciones residentes?

A los efectos de abordar y responder a cada una de las interrogantes anteriormente mencionadas, se emplea técnicas de índole cualitativa, a saber: el proceso sociohistórico del asentamiento COTRAVI es reconstruido a partir de las entrevistas en profundidad (grupales in situ y entrevistas individuales y grupales semiestructuradas) realizadas en el marco del Proyecto de Mejoramiento Barrial' ${ }^{2}$ (2014-2016) a vecinas/os del asentamiento que permitan acceder a los discursos de los residentes originarios y de los recientes en el asentamiento.

Así mismo, se utilizará el análisis de las opiniones vertidas en el censo de personas, hogares y viviendas desarrollado en el marco del Proyecto de Mejoramiento Barrial de COTRAVI.

\section{Producción social del hábitat en el marco de la "ciudad informal"}

\section{III.1. La producción social del hábitat en contextos de precariedad socio-urbano-habitacional}

En las últimas décadas en las ciudades latinoamericanas se ha hecho más visible la exclusividad residencial y la precariedad urbano-habitacional, claras manifestaciones de los cambios socioeconómicos ${ }^{3}$ que han reconfigurado la propia

2 Proyecto de Mejoramiento Barrial Integral del Asentamiento Irregular COTRAVI: refiere a un proyecto ejecutado por el Consorcio IPRU - CSI para el Programa de Mejoramiento Barrios (PMB - MVOTMA) del Ministerio de Vivienda Ordenamiento Territorial y Medio Ambiente.

3 A partir de la aplicación de las políticas de reforma del Estado y la liberalización de la economía -apertura comercial, desregulación económica y financiera, políticas monetarias ortodoxas, reducción del gasto público, entre otras-, han consolidado, a lo largo de la década de 1990 y principios del 
estructura y morfología urbana de las ciudades. Este proceso se materializa a través de los diversos patrones de localización de diferentes segmentos sociales de la población -y sus actividades- como parte del proceso de producción de la ciudad.

En virtud de lo mencionado, en concordancia con Martim Smolka y Laura Mullahy (2000), "el paisaje de las ciudades latinoamericanas suele estar marcado por la contradictoria coexistencia de áreas residenciales para la clase adinerada [...] y las áreas marginales donde está confinada parte de la población urbana de bajos recursos" (Smolka y Mullahy, 2007, p. 27).

Por tanto, en este contexto, cobra importancia la lógica hacedora de ciudad, denominada de la necesidad; modalidad, esta última, desarrollada principalmente por los sectores populares de la ciudad, sectores excluidos del mercado de suelo urbano que no tienen otra opción que desarrollar el proceso de producción social de su hábitat ${ }^{4}$ (PSH) en las peores localizaciones urbanas.

Esto conlleva a la producción de una ciudad que resulta de la convergencia de la ciudad formal (relacionada tanto con la lógica estatal como con la mercantil) y la ciudad informal ${ }^{5}$ (vinculada a la lógica de la necesidad habitacional que se hace presente en los sectores poblacionales

siglo xxi, en nuestro país, el modelo de desarrollo económico "neoliberal". Conllevando así a los conocidos procesos de desestructuración del aparato productivo, la desindustrialización, el aumento del desempleo y la pobreza junto con la crisis de las economías regionales (Olesker, 2001).

4 Este término se comenzó a implementar a comienzos de la década de los 70, a partir de la necesidad de generar formas de canalizar e incrementar los esfuerzos que realizan los sujetos al producir su propio espacio habitable. Concretamente, se entiende por PSH, como "el proceso de desarrollo del hábitat, espontáneo o planificado, para alcanzar la satisfacción de necesidades, tangibles e intangibles de los sectores sociales tradicionalmente excluidos" (Romero, 2004, p. 5).

5 Ciudad que se desarrolla al margen de la planificación urbanística, conformando una parte considerable del suelo urbano; y que junto a la ciudad formal origina un territorio complejo, donde la formalidad y la informalidad se superponen en una composición urbana compleja (Tardin, 2006). 
menos favorecidos por el trickle down effect, en el marco del desarrollo económico-capitalista). Estos procesos consolidan, en términos de Tardín (2006), una "ciudad mutante".

\section{III.2. Caracterización de las lógicas de producción y reproducción de la ciudad que operan en COTRAVI}

En este punto, se avanza en la descripción de las lógicas de producción y reproducción de la ciudad que han incidido en este asentamiento irregular de la zona oeste de Montevideo, tomando como referencia algunos de los aportes conceptuales de Abramo, referidos a la producción de la estructura urbana en las ciudades latinoamericanas en las últimas décadas (Abramo, 2012, p.36).

Al respecto, corresponde explicitar que la producción de las ciudades latinoamericanas han sido el resultado del funcionamiento y conjunción de tres lógicas de coordinación social: Mercado, Estado, y la Lógica de la Necesidad. Esta última se constituye a partir de un conjunto de acciones individuales y colectivas que promueven la producción de lo que se ha de denominar "ciudades populares".

Estas formas de producción urbana se han desarrollado a partir de una modalidad de acceso al hábitat caracterizada por su habitual proceso de: ocupación/autoconstrucción/ autourbanización y consolidación. Esta modalidad, de producción de la ciudad popular, se presenta como una nueva variante que articula la lógica del mercado con la de la necesidad, y se manifiesta socialmente como el mercado informal de suelo (Abramo, 2012, pp. 36-38).

Al respecto, en Montevideo el mercado de suelo urbano sigue sus propias reglas y, en esa lógica, no encuentra lugar el concepto de necesidad habitacional o de derecho al acceso a la vivienda digna. Esta necesidad para muchos sectores se manifiesta en el territorio en extensas áreas de expansión residencial, caracterizados/marcados por la precariedad socio-urbano-habitacional (IM, 2010, p. 14). 
En este contexto capitalino de producción de ciudad es que se inscribe el caso de la microzonificación informal denominada COTRAVI, que se constituye como asentamiento irregular el 4 de abril de 1998; a partir de una ocupación, en cierta medida muy organizada, de lo que entonces era un predio semirural privado, localizado en la periferia oeste de la ciudad de Montevideo (IPRU-CSI, 2014).

Lo mencionado denota que población original residente en COTRAVI debió resolver irregularmente lo que no logró solucionar por la vía de la formalidad; ocupando tierras ubicadas en los bordes periféricos de la ciudad, en pésimas localizaciones urbanas, con severas carencias de servicios y equipamientos básicos. Están muy presentes y se reiteran en los relatos de vecinos y vecinas, los motivos que los llevaron a habitar COTRAVI hacia fines de la década del 90, entre los que se encuentran el constante deterioro económico, la continua pérdida de puestos laborales, los sucesivos aumentos del mercado de alquileres, el incremento del coste de vida de las familias, entre otros.

Desde una mirada territorial, actualmente COTRAVI se presenta como un enclave urbano dentro de un territorio que presenta un paisaje variado, complejo y con superposiciones de usos. Desde los bordes del asentamiento, se aprecia la discontinuidad de la forma, de los usos y del paisaje. Por un lado, el espacio rural, la mayor parte del mismo ha abandonado la producción. Por otro, los nuevos usos, los espacios de ciudad más tradicionales conformados por los antiguos barrios y las cooperativas de vivienda. Al norte de la trama del asentamiento se observa el avance y consolidación de los nuevos usos del suelo, vinculado a la instalación de grandes estructuras empresariales de almacenamiento. Hacia el suroeste, el borde se vuelve rural con grandes extensiones vacías. Así como también es posible observar desde sus bocacalles, diferentes vistas del Cerro de Montevideo y el área rural a lo lejos (IPRU-CSI, 2014). 
No obstante, corresponde establecer que COTRAVI se encuentra emplazado en un espacio de la ciudad, caracterizado por la precariedad socio-urbano-habitacional, asociada al desarrollo de un hábitat informal cuya materialización presenta carencias de habitabilidad, así como precariedad en conexión/acceso a servicios básicos, condición de tenencia de la vivienda y lejanía al equipamiento y transporte colectivo. Estas carencias no solo se encuentran en el propio espacio que se habita, sino también en el entorno inmediato y/o área circundante. Esto sin duda disminuye la calidad de vida de las personas que habitan en estas condiciones, limitando sus posibilidades de desarrollo así como proyecto de vida (Trinidad, 2012, 2017).

\section{III.3. Revisitando los aportes de Elias y Scotson acerca de la figuración established-outsiders}

A los efectos de realizar un abordaje integral acerca de las dinámicas de producción social del hábitat desarrollado en COTRAVI, se considera conveniente contemplar el acceso diferencial al espacio interior del asentamiento por parte de las/os vecinas/os, así como los procesos de diferenciación socioeconómico habitacionales que se suscitan entre los residentes.

Se entiende conveniente, a los efectos de iluminar el presente análisis, sobre los mencionados procesos, valerse de los aportes de Norbet Elías y John Scotson (2000) en su estudio "Os Estabelecidos e os Outsiders: Sociologia das Relações de Poder a partir de uma Pequena Comunidade".

Para comenzar, Norbet Elías y John Scotson (2000), en su análisis de las relaciones entre residentes de una misma localidad inglesa cuestionaron la habitual disociación entre estructura e historia:

... de acuerdo con las convenciones actuales del pensamiento, la historia no tiene estructura y la estructura no tiene historia [constatando sin embargo que] sin una referencia al 
desarrollo de Winston Parva, su estructura en la investigación permanecería incomprensible. El esbozo de ese desarrollo fue parte integrante de la investigación sobre la estructura; sobre la configuración de la comunidad en un momento dado. (2000, p. 67)

En otras palabras, comprender las relaciones sociales en Winston Parva exigía introducir el factor tiempo de residencia en la estructura de análisis. Concretamente, Elías y Scotson, estudiaron una localidad en la cual no existían marcadas diferencias de clase, etnia o estatus entre las poblaciones de dos barrios obreros; que a simple vista eran muy similares y donde los residentes de uno de los barrios (el más antiguo) se sentían miembros de un grupo superior al barrio vecino (el más reciente) a la vez que los residentes de este último barrio aceptaban pertenecer a un grupo de menor valía, relacionándose en una figuración del tipo "establecidos-outsiders". Como señalan estos autores, el tiempo de residencia es un factor de clasificación de familias y grupos: "términos [antigüedad y nuevo] apuntan para diferencias específicas en la estructura de los grupos y que ese tipo de diferencia estructural desempeña un papel en su jerarquización" (Elias y Scotson, 2000, p. 53).

Así, según la propuesta de los autores de referencia, es posible vislumbrar en la figuración social de establecidos y outsiders los procesos temporales relativos a la antigüedad de los grupos residentes y sus efectos en la cohesión social diferencial de cada uno de ellos y el impacto de dicha "cohesión diferencial" en las relaciones entre los miembros de los distintos grupos residentes de la mencionada comunidad. En efecto, la cohesión social se manifestaba en el monopolio por parte de los established de ciertas instituciones de la comunidad; y, por ende, la exclusión del acceso a las mismas de los outsiders y la sanción por parte de la comunidad sobre los miembros del grupo establecido que se relacionaran con los recién llegados (Elias y Scotson, 2000, p. 53). 
Al respecto, los autores de referencia señalan que los comentarios cotidianos hacían visible un imaginario social en el que los residentes antiguos no solo marcaban una diferencia respecto de los nuevos residentes, sino que además acentuaban la idea de ser "mejores" que los nuevos (Elias y Scotson, 2000, p. 83). Además de la mencionada diferenciación, explicitada en el discurso de los antiguos residentes, se expresaba también una práctica permanente de "evitar" el contacto con los otros justificando esta práctica discriminatoria en una estigmatización de tipo social, al tildarlos "a todo idistintamente de burdos y poco educados" (Elias y Scotson, 2000, p. 83). Esto conlleva a la generación de barreras sociales y simbólicas en los procesos interacción, intercambio y contacto social entre los established y los outsiders.

En virtud de lo explicitado, el autor de referencia,afirma que

... un grupo puede estigmatizar a otro efectivamente solo mientras esté bien establecido en posiciones de poder de las cuales el grupo estigmatizado se encuentra excluido. Mientras perdure esta condición, el estigma de la desgracia colectiva impuesto a los marginados puede persistir. (Elias y Scotson, 2000, p. 89)

En efecto, por lo tanto, se destacan dos elementos centrales en el factor antigüedad: por un lado, la cohesión social interna y su consecuente sentimiento de comunidad; y, por otro, la posibilidad de manejar el control social.

En virtud de lo expuesto, en los siguientes apartados se procederá a efectuar el correspondiente análisis de las lógicas de producción y reproducción de la ciudad que operan en COTRAVI; así como el particular devenir de la estructura socio-espacial fraccionada de COTRAVI a la luz de los aportes de Elias y Scotson (2000). 


\section{COTRAVI: una mirada retrospectiva a su proceso de construcción}

La producción social del hábitat, desarrollada por las familias originarias de COTRAVI, comienza un 4 de abril de 1998 a partir de una ocupación, en cierta medida muy organizada, de un predio de 22 hectáreas ubicado en la zona oeste de Montevideo, con un loteo inicial de 354 predios y con múltiples previsiones de traza vial, amanzanamientos y equipamientos.

A nivel de las viviendas, las familias edifican sus unidades habitacionales caracterizadas al principio por la utilización de materiales livianos; para luego, mejorar la estructura originaria de la unidad habitacional.

Otro aspecto relevante de la dinámica de conformación del hábitat-barrio-territorio, está vinculado a la previsión y reserva de áreas para dotaciones de infraestructura, equipamientos y/o la conformación de sistemas verdes articulados entre sí.

En este sentido, COTRAVI cuenta con un proyecto prefigurado por los vecinos donde se asigna al espacio central ocupado por la Cañada, la condición de espacio público, reservado para canchas y locales de uso comunal.

La conformación y ordenamiento del trazado interno del asentamiento permitió también la previsión de ciertos espacios con destinos no residenciales como ser la plaza, así como los sucesivos intentos fallidos de construcción de una policlínica, guardería y/o salón comunal.

Al respecto, mención especial requieren los procesos de ocupación posteriores al organizado originalmente, por parte de familias que se asientan en las proximidades de la Cañada. Este hecho, parece haber marcado también la historia del barrio, en el entendido que su ocupación impactó en la proyección de los espacios comunitarios previstos.

De acuerdo a lo expuesto por los vecinos, el sector del asentamiento, donde se ubica la Cañada y sus espacios circundantes, fue creciendo a impulsos más individuales- 
familiares, quienes no habrían asumido los "acuerdos iniciales, las formas de distribución de los lotes y el reconocimiento al grupo de vecinos referentes-organizados" (IPRU-CSI, 2014).

La situación socio-económico-habitacional en las que se encuentra esta población (localizada en la Cañada) genera y consolida fenómenos de concentración de precariedad urbana y exclusión territorial. Procesos que impactan en el imaginario social del resto de la población residente, estableciéndose construcciones sociales de carácter estigmatizante sobre esta población

\section{1. COTRAVI y su particular estructura socio- espacial fraccionada}

\section{1. 1. Tiempo de residencia y los límites sociales-simbólicos presentes en COTRAVI}

La indagación del proceso sociohistórico de conformación del asentamiento COTRAVI permitió identificar temporalidades (y condiciones materiales) diferenciales en el proceso de llegada y del propio proceso de habitar que se traduce en una configuración socio-espacial fragmentada.

En este sentido, es posible vislumbrar una fuerte correlación entre tiempo de residencia, el lugar de emplazamiento al interior de COTRAVI, así como las condiciones socioeconómicas habitacionales, conllevando a la consolidación de una cohesión social diferencial, lo que nos permite comprender las relaciones entre los residentes de los sectores denominados "los de arriba" y "los de la Cañada".

Lo mencionado, justamente, refiere a una de las hipótesis propuestas por Elias y Scotson (2000), es decir que el tiempo diferencial de residencia permite comprender y explicar las condiciones desiguales en tanto las relaciones (de poder) entre establecidos y outsiders, que definen claramente las formas de relacionamiento entre los residentes de una misma unidad espacial. 
Justamente, para el análisis del caso de estudio, se toma una de las más relevantes hipótesis de la propuesta de Elias y Scotson (2000), es decir la dimensión tiempo de residencia; empero, para el caso particular de COTRAVI, además de dicha dimensión, es necesario contemplar también "lugar de emplazamiento o residencia" así como las condiciones socioeconómicas habitacionales de las familias y las formas organizativas de los grupos presentes en el mismo espacio residencial.

Estas dimensiones propician el desarrollo o generación de límites sociales y simbólicos que operan al interior de espacios y grupalidades/poblaciones. Así, además de los límites sociales, en tanto formas objetivadas de diferencias sociales manifestadas en el acceso y la distribución desigual de recursos y oportunidades que en el caso del espacio urbano refiere al desigual acceso a la ciudad, debemos tener presentes los límites simbólicos, es decir, las distinciones conceptuales realizadas por los actores sociales para categorizar objetos, personas y prácticas, que mantienen relaciones complejas (refuerzo, inversión, cuestionamiento, etc.) con los límites sociales (Lamont y Molnár; 2002 Apud Carman, et al., 2013, pp.17-18).

A modo de cierre, los procesos de segregación, en un mismo territorio segregado, dan cuenta de procesos de diferenciación, generando muros invisibles que segregan dentro del propio territorio segregado, con expresiones de estigmatización muy fuertes. En tal sentido, los procesos mencionados impactan en la sociabilidad y vínculos interpersonales, exacerbando los proyectos individuales y debilitando las capacidades de construcción de lo colectivo. La integración territorial entre los grupos socioeconómicamente diferentes y las posibilidades de convivencia se fragilizó con expresiones extremas como la discriminación y estigmatización. 
En este sentido, las posibilidades de construcción de lo colectivo, en este tipo de escenario, también están vinculadas a las formas de organización y experiencias de participación, ligadas a la resolución de necesidades, muchas de ellas materiales, pero también simbólicas.

\section{IV.1.2. Los procesos del habitar en COTRAVI: "como que hay dos} cotravis, los de la Cañada y nosotros"

La especificidad del proceso histórico de conformación de COTRAVI, las características geográficas de su emplazamiento, las condicionantes socioeconómico habitacionales y culturales de su población presentan particularidades, pertenencias e identidades diferenciales que se expresan, también, en distintas dinámicas del habitar así como de la organización y participación comunitaria a lo largo de su historia.

Estas particularidades se reflejan en la cotidianeidad, en las formas organizativas, en la interacción colectiva entre vecinos, que también han variado a lo largo del tiempo. Transitando por momentos en lo que la gestión caracterizó por acciones individuales de vecinos más movilizados, hasta comisiones de vecinos más estables y otras formas organizativas colectivas menos estructuradas, movilizadas por necesidades particulares de la zona en que residen; a modo de ejemplo: los vecinos de la zona de la Cañada.

Del relato vecinal surgen dos zonificaciones a la interna del COTRAVI, claramente diferenciadas, que responden tanto a la particularidad topográfica del asentamiento así como al momento histórico de ocupación y de las formas organizativas desarrollada por cada grupo: "los de arriba" y "la zona de la Cañada".

"Los de arriba" son efectivamente quienes están en una altura mayor del terreno, a los que también se incorporan a esta categoría los vecinos que viven cerca de Camino Cibils. Una población que en buena parte habita desde los inicios del asentamiento, así como los que ostentan las mejores 
locaciones espaciales para residir. Además, se los asocia se nombra a quienes integran la comisión vecinal porque la sede se encuentra allí y porque históricamente los integrantes de la comisión pertenecen a esa zona.

Por su parte, los vecinos denominados "los de la Cañada", se caracterizan por ser una población que presenta toda una historia de relegación y procesos de desafiliación. Además, es un grupo de vecinos que se caracterizan por encontrarse en las más precarias condiciones socioeconómico habitacionales. También, en un inicio desarrollaron una comisión propia, a los efectos de movilizarse para reivindicar sus derechos vulnerados. Sin embargo, esta organización fue perdiendo vigor a lo largo de estos años. Empero, la organización de esta grupalidad generó una relación de extrema conflictividad con el resto del barrio, dado que se generaba una comisión en paralelo a la comisión "vecinalmente legitimada".

En efecto, la ocupación de la Cañada pareciera marcar un importante punto de inflexión en la historia de COTRAVI, dado el establecimiento en predios que estaban destinados, según el proyecto original: a espacios públicos, policlínica o guardería, salón comunal; y que, además, la comisión del barrio se había comprometido ante el MVTOMA a preservar de futuras ocupaciones. Las ocupaciones en la zona de la Cañada conllevaron a fuertes procesos de fragmentación al interior del propio asentamiento; así como la conformación de otra grupalidad de vecinos que se oponía a la propia Comisión Vecinal del barrio, lo que propició un mayor distanciamiento u escisión entre los denominados vecinos de mayor antigüedad en COTRAVI (established) y los nuevos ocupantes de la zona de la Cañada (outsiders).

La mencionada situación es recordada por la tensión generada no solo de carácter barrial, sino también personal, por parte de los vecinos originarios: 
Cuando ocuparon en la cañada, yo estaba en la comisión y fuimos a la seccional y de la seccional dijeron que nosotros no éramos los dueños que lo tenía que hacer el Ministerio de Vivienda. Nosotros fuimos a informarles cuando habían tres y ellos vinieron al año o año y pico [2006], cuando habían veinte, con un escribano, un secretario y un abogado del Ministerio y ya estaba todo ocupado. Nosotros queríamos mantener los espacios, pero claro no podíamos con eso y nosotros no teníamos ninguna potestad, tampoco generar algo personal, cómo le íbamos a decir a otros que no ocuparan si nosotros éramos también ocupantes. (IPRU-CSI, 2014)

Por su parte, la población ocupante en la Cañada se encontraba en una situación económica, social y cultural significativamente más precarizada. En este sentido, las familias que viven en la Cañada, explican su procedencia de forma similar a quienes ocuparon inicialmente en COTRAVI, dicen que viven desde hace menos de diez años y, en la mayoría de los casos, los relatos de cómo y por qué llegaron al barrio, refieren a la falta de opciones o alternativas y la oportunidad de un lugar o espacio a la venta:

Yo vivo hace nueve años acá. Donde vivíamos teníamos lanzamiento y teníamos un hijo chico. En todos lados pedían en dólares. Una muchacha me dijo que había un terreno y lo compré por tres mil pesos. No había nada ahí, estaba vacío. (IPRU-CSI, 2014)

Yo estoy viviendo ahí hace seis años, ya estaba la casita hecha, fue por mi hermana porque si no me quedaba en la calle. (IPRU-CSI,2014)

Además, explican que, ante su condición de extrema precariedad socioeconómico habitacional en la cual se encontraban, durante el 2010 al 2012 desarrollaron un conjunto de actividades movilizadoras para reivindicar sus derechos: 
... la comisión no nos tomaba mucho en cuenta, decidimos movernos por la nuestra para solucionar nuestra situación, pero principalmente lo hicimos por nuestros hijos [...]. Llegamos al MVOTMA, llegamos al Palacio Legislativo y a la Intendencia [...] en mayo de 2010 se cortó la ruta, allí logramos entrevistas. Simplemente nosotros no éramos una comisión sino referentes del barrio que frente a las problemáticas y viendo que la comisión de allá arriba no nos tomaba en cuenta -como que no éramos del barrio nosotros- entonces formamos este nuevo grupo. (IPRU-CSI, 2014)

La denominación "Vecinos de la Cañada" o "los de la Cañada”, indica no solo el lugar físico en el que se ubican dentro del barrio, sino también parece dar cuenta de cierta forma de segmentación interna operando a nivel material y simbólico en la dinámica del territorio. Es posible visualizar que existe una construcción de la percepción de quiénes son unos y quiénes son otros en COTRAVI, y por lo tanto, a los relacionamientos que se construyeron, construyen y podrán construirse.

Se hace referencia, en este sentido, a lo que se ha mencionado en puntos anteriores de este documento respecto de un barrio que aparece dividido entre "los de arriba" y "los de la Cañada". Ciertamente, estos últimos no tienen ubicación en el espacio del barrio, dado que los vecinos originarios (los de arriba) no generaron un código de similar connotación para con los vecinos que residen en las proximidades del curso de agua, como podría ser: "los de abajo". Empero, se los nombra de forma diferente. Al estar por fuera de la nomenclatura cotidiana, parecieran visualizarse y autovisualizarse como "sin lugar". 


\section{Conclusiones}

A partir del presente estudio, fue posible corroborar la pertinencia de la proposición efectuada por Elias y Scotson (2000), es decir que el factor temporalidad, más precisamente el tiempo de residencia, permite comprender y explicar las condiciones de desigualdad en el seno de una comunidad; así como de las relaciones de poder, que determinan el prestigio, moldeando las formas de relacionamiento entre los established y outsiders.

Para el caso concreto de COTRAVI, esta hipótesis fue corroborada, con ciertos matices, en el sentido de que la diferencia en el tiempo de residencia permite comprender los actuales procesos de segregación y fragmentación espacial presentes, así como los procesos de estigmatización que recaen en la población residente en la zona de la Cañada (outsiders).

Concretamente, la antigüedad de residencia define qué lugares ocuparían las familias al interior del espacio (a modo de ejemplo, en el marco de conformación de COTRAVI, aquellos residentes que ocuparon hacia 1998, obtuvieron las mejores locaciones, en comparación con los más recientes) así como las condiciones en que habitarían (mayor o menor nivel de precariedad socio-urbanohabitacional).

Sin embargo, este supuesto (tiempo de residencia en el asentamiento) no es suficiente para explicar la totalidad de las dinámicas existentes al interior del asentamiento. En el entendido que debe analizarse de forma articulada con otras dimensiones como: a) las condiciones socioeconómicas habitacionales, y b) el "lugar de emplazamiento o residencia” al interior del asentamiento.

La conjunción de estas dimensiones/factores, permiten lograr un abordaje integral del objeto de estudio, permitiéndonos comprender la existencia y persistencias de los actuales límites sociales como simbólicos y desigualdades en el acceso a recursos existentes. Lo mencionado, 
justamente, cuestiona aquellas construcciones que a priori consideran a los asentamientos irregulares como espacios homogéneos.

La conjunción de estas dimensiones/factores, permiten lograr un abordaje integral del objeto de estudio, permitiéndonos comprender la existencia y persistencias de los actuales límites sociales como simbólicos, desigualdades en el acceso y distribución de recursos; y también de prestigio, en un espacio considerado externamente a priori como homogéneo.

Además, otro factor clave que explica esta realidad refiere a las formas organizativas desarrolladas, materializado principalmente en la figura de la Comisión de Vecinos (electa por buena parte de la población residente). Esta grupalidad, como fuera descripta, existe desde la propia creación del asentamiento a los efectos de reivindicar sus necesidades en los diferentes espacios institucionales. Este proceso genera lo que Elias y Scotson (2000) denominan cohesión social diferencial, base constitutiva de un "nosotros”. Además, la Comisión de Vecinos es una fuente importante de poder y referencia barrial. Este punto es central para explicar la pertinencia de la hipótesis de los autores de referencia con relación a este estudio.

Por ende, la generación de una comisión vecinal en paralelo, por parte de los vecinos asentados en la zona de la Cañada y sus alrededores, ahondó aún más las brechas existentes. Brechas provenientes de ocupar espacios previstos para el desarrollo de equipamientos comunitarios, los cuales presentan una fuerte carga simbólica y afectiva -de carácter positivo-, que incide directamente en la percepción que presenta el resto de la población de COTRAVI (established) respecto a los vecinos de la Cañada (outsiders).

A modo de cierre, se entiende pertinente introducir una interesante opinión esgrimida por un vecino entrevistado, que resume sintéticamente el quid del asunto de este estudio: "Lamentablemente, a veces, entre pobres nos discriminamos” (IPRU-CSI, 2014). 


\section{Bibliografía}

Abramo, P. (2012). La ciudad com-fusa: mercado y producción de la estructura urbana en las grandes metrópolis latinoamericanas. Revista EURE, N. ${ }^{\circ}$ 114, vol. 38 (pp.s/d).

Baráibar, X. (2009). Tan cerca, tan lejos: acerca de la relevancia "por defecto" de la dimensión territorial. Departamento de Trabajo Social, Facultad de Ciencias Sociales, UdelaR. Montevideo, Uruguay. Revista Fronteras, vol. (5), pp. 59-72.

Borja, J. (2003). La ciudad conquistada. Madrid: Alianza Editorial.

Carman, M.; Vieira da Cunha, N.; Segura, R. (coord.) (2013). Segregación y diferencia en la ciudad. Quito: Consejo Latinoamericano de Ciencias Sociales (CLACSO).

Cravino, C. (2014). Las villas de la ciudad. Mercado e informalidad urbana. Buenos Aires: Universidad Nacional de General Sarmiento.

Elias, N.; Scotson, L. (2000). Os estabelecidos e os outsiders. Sociologia das Relações de Poder a partir de uma Pequena Comunidade. Sao Pablo: Zahar.

Intendencia de Montevideo (IM) (2010). Documento de Avance Revisión del Plan Montevideo (Plan de Ordenamiento Territorial 1998-2005). "Hacia del Plan Montevideo 2010-2020". Montevideo: Intendencia de Montevideo.

IPRU CSI (2014). Relevamiento y Diagnóstico Integral Cotravi. PBM-MVOTMA (mimeo).

Machado, G.; Rodríguez, A.; Rocco, B.; Álvarez, M. (2014). Los límites de la política y la política de los límites en los procesos de urbanización. En: Acosta, Y.; Casas, A.; Mañan, O.; Rodríguez, A. y Rossi, V. (coords.), Sujetos colectivos, Estado y capitalismo en Uruguay y América Latina. Perspectivas críticas. Montevideo: Trilce-Espacio Interdisciplinario UR. 
Olesker, D. (2001). Crecimiento y exclusión. Nacimiento, consolidación y crisis del modelo de acumulación capitalista en Uruguay (1968-2000). Montevideo: Trilce.

Ortiz, E.; Zárate, L. (comps.) (2002). Vivitos y coleando. 40 años por el hábitat popular en América Latina. México DF: HIC-AL/UAM.

Romero, G. (1994). Las alternativas y opciones de la autoconstrucción de vivienda en América Latina. En: Pelli, V.; Lungo, M.; Romero, G.; Bolivar, T., Reflexiones sobre la autoconstrucción del hábitat popular en América Latina. San Salvador: CYTED Red XIV.

Smolka, M.; Mullahy, L. (eds.) (2007). Perspectivas urbanas. Temas críticos en politicas de suelo en América Latina. Cambridge (MA): Lincoln Institute of Land Policy.

Tardin, R. (2006). La ciudad informal. En: Nogué, J.; Romero, R. (ed.), Las otras geografías. Valencia: Editorial Tirant lo Blanch.

Trinidad, V. (2012). Las urbanizaciones informales. Una modalidad de acceso al Hábitat y la ciudad contemporánea. Tesis de grado. Facultad de Ciencias Sociales. UDELAR.

Trinidad, V. (2017). Habitar la ciudad informal: producción del hábitat en condiciones de precariedad sociourbano-habitacional. En: XVI Jornadas de Investigación de la Facultad de Ciencias Sociales. Facultad de Ciencias Sociales, Comisión de Investigación Científica (CIC) de la Facultad de Ciencias Sociales (FCS). 13, 14 y 15 de setiembre de 2017. Mimeo. 


\section{Apéndice}

\section{Ubicación del asentamiento irregular COTRAVI}
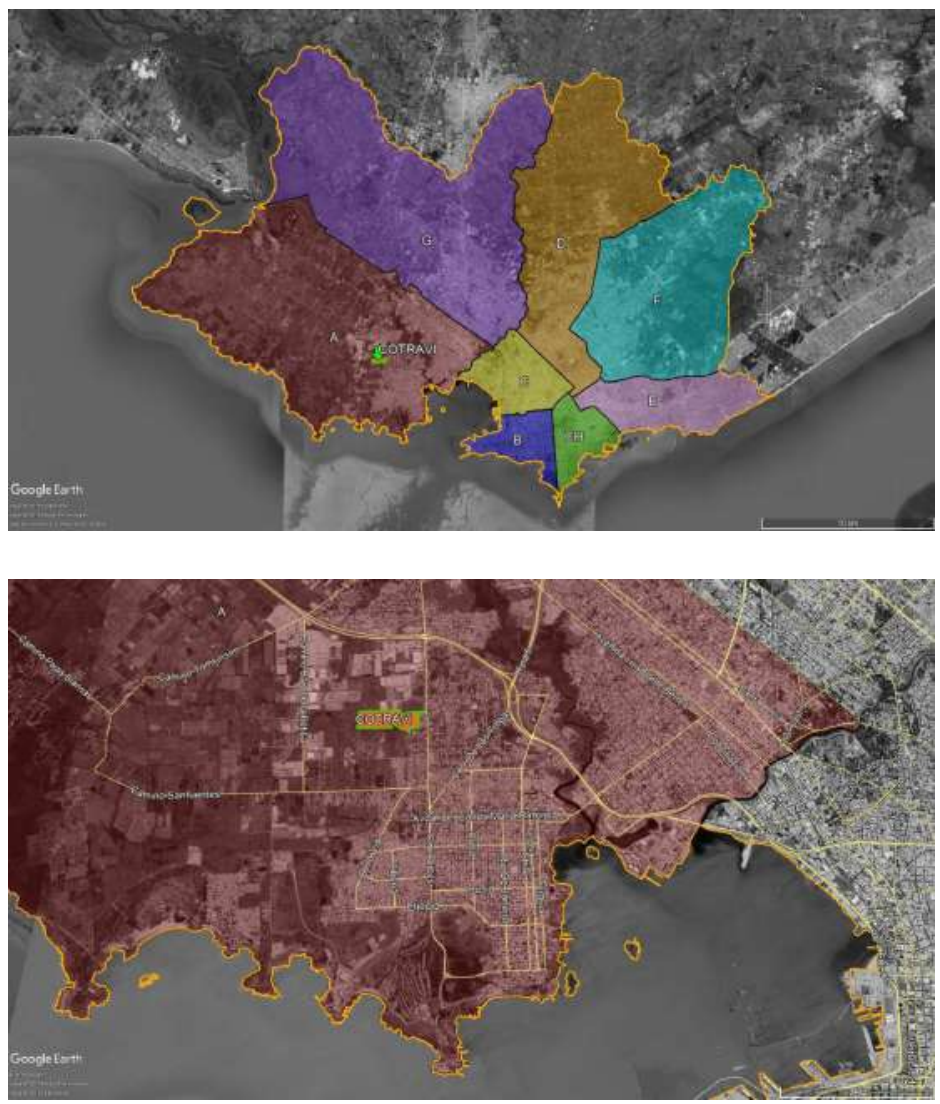

Fuente: Elaboración propia a partir de datos de la IM y PMB-MVOTMA. 
222 • Segregación socio-espacial en las ciudades latinoamericanas

2. Plano actual del asentamiento irregular COTRAVI

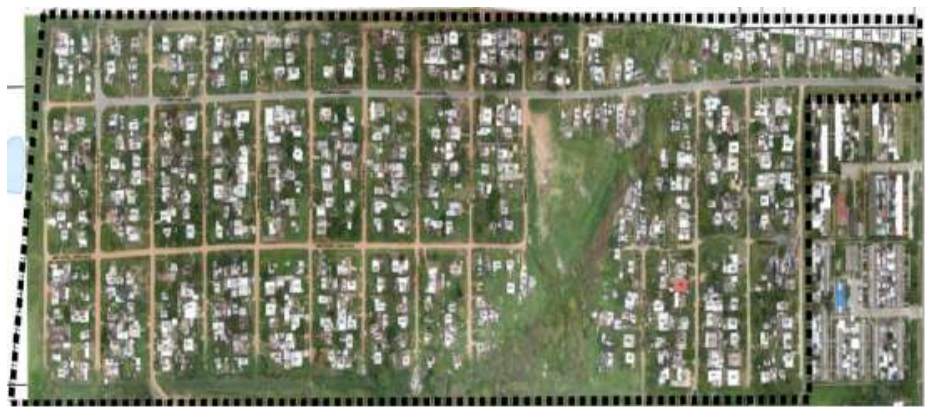

Fuente: Relevamiento y Diagnóstico Integral Cotravi. Consorcio IPRU-CSI / PMB-MVOTMA

3. Georreferenciación de los dos sectores: "los de arriaba" y "los de la Cañada"

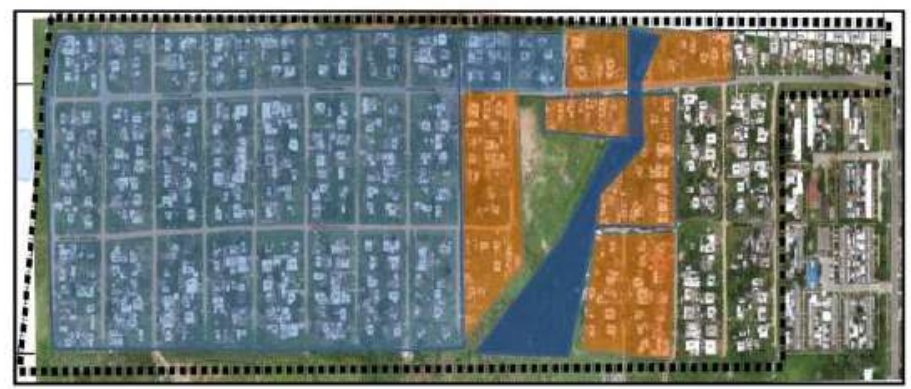

"Los de Arriba"

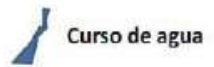

"Los de la Cañada"

Fuente: Elaboración propia. 


\title{
Belo Horizonte, Brasília e Lisboa: observando processos de gentrificação ${ }^{1}$
}

\author{
Rachel de Castro Almeida, SÁvio Guimarães y Patrícia Pereira
}

\section{Resumo}

As estratégias de gentrificação, ou enobrecimento urbano, revelam assimetrias de poder e dominações de ordem econômica, social e cultural que enfatizam ou reinventam os processos de produção de desigualdades socioespaciais. Iniciativas esparsas conduzidas pelo mercado para a reapropriação e revitalização de zonas centrais nas décadas de 1970 e 1980, nas grandes cidades norte-americanas e europeias, ganham consubstancialidade de política urbana nos anos 90, configuradas a partir das técnicas de planejamento estratégico associadas ao marketing urbano, e a gentrificação em breve se torna uma estratégia urbana global. Há nessas reconfigurações espaciais um alarde em torno da criação de uma espacialidade diferenciada. Vários estudos indicam que nessa dinâmica de enobrecimento os resultados remetem à produção de um espaço segregado, associado às práticas globais de consumo, a alterações nos padrões de sociabilidade, à homogeneização de paisagens comerciais e residenciais e à destradicionalização das práticas locais.

1 Este trabalho faz parte de uma pesquisa científica, em andamento, nomeada "Aqui e ali - Brasília, Belo Horizonte e Lisboa: a amplitude dos processos de gentrificação urbana”, financiada pela Fundação de Amparo à Pesquisa do Distrito Federal (FAP/DF), edital 04/2017. E teve o apoio da Fundação para a Ciência e a Tecnologia (FCT/MCTES, Portugal) - bolsa de pós-doutorado de Patrícia Pereira (SFRH/BPD/92799/2013). 
Esse processo é geralmente marcado por um conjunto de tensões que atuam de forma concomitante, demonstrando as dinâmicas que conformam a vida urbana. Tendo em vista este pano de fundo, o principal objetivo deste ensaio é abordar três estudos de caso: o Mercado Central de Belo Horizonte, as quadras residenciais e comerciais 412/413 da Asa Norte de Brasília e a Rua Poço dos Negros, em Lisboa. Esta pesquisa ainda em fase exploratória que recorre à etnografia para compreender as atuais atividades comerciais empreendidas nesses espaços, o modo como o cotidiano é vivenciado, seus principais usuários, suas trocas materiais e simbólicas.

As conclusões iniciais sugerem que esses espaços se caracterizam pelo fato de evidenciarem historicamente múltiplas tendências e processos sociais, econômicos e culturais que se reelaboram continuamente, demonstrando dinâmicas dialéticas de gentrificação e resistência cotidiana.

\section{Palavras chave}

Gentrificação; espaços comerciais; transformações urbanas.

\section{Introdução}

Este artigo é fruto de uma pesquisa ainda exploratória que procura estabelecer comparações entre três realidades distintas, lidas a partir de espaços comerciais de três metrópoles, Belo Horizonte e Brasília, no Brasil e Lisboa, em Portugal. O objetivo deste estudo é o de perceber as dinâmicas e transformações nesses espaços comerciais visando analisar tensões e relações dialéticas entre gentrificação e resistência no cotidiano.

Desse modo, em Belo Horizonte, abordaremos o Mercado Central, um espaço de referência para a população local e regional, que tem sua história associada à própria história da cidade e configura há décadas um ponto 
importante de turismo. Em Brasília, percorreremos as dinâmicas de transformação urbana nas quadras residenciais e comerciais 412/413 e 213/214, da Asa Norte, decorrentes especialmente da implantação do Parque Olhos d'Água, na década de 1990. Em Lisboa, a pesquisa tem como foco de estudo a área em torno da Rua Poço dos Negros, situada no centro histórico da cidade.

Estes três estudos de caso consistem em espaços públicos comerciais que vêm já há algum tempo se evidenciando enquanto fontes instigantes à pesquisa, em razão de numerosas transformações constatadas em sua conformação espacial e social e que aqui serão explicitadas num esforço analítico de sistematização do conhecimento que tais espaços e seus usos permitem ser assimilado.

Assim, o presente ensaio é resultado de um trabalho etnográfico, efetuado por uma equipe de pesquisadores, por meio de uma série de incursões ao local. O método etnográfico tem a vantagem de evitar aquela dicotomia que opõe o indivíduo e as megaestruturas urbanas, pois a perspectiva de análise "de perto e de dentro" (Magnani, 2002) é capaz de apreender os padrões de comportamento, múltiplos e heterogêneos, os grupos, as redes e os sistemas de troca. Por esta via, as análises deste trabalho recaíram predominantemente sobre as atuais atividades comerciais, o cotidiano vivenciado em seus espaços, seus principais usuários e suas trocas materiais e simbólicas. Com o desenrolar desta pesquisa espera-se discutir questões que se encontram na primeira linha do debate teórico e metodológico atual sobre gentrificação, entre outras, a utilização do conceito em contextos distantes daquele (anglo-saxônico/europeu e norteamericano) em que foi produzido e as novas possibilidades conceituais e teóricas que desenhos de pesquisa verdadeiramente comparativos Bernt (2016), como este, permitirão acionar. Entendemos que os recentes debates em torno do uso do conceito gentrificação em cidades fora do contexto europeu e norte-americano, e em específico na América Latina (Bernt 2016, Ghertner 2015, López-Morales 2015 
e López-Morales, Shin e Lees 2016), devem incentivar a (auto)reflexão sobre as formas como o mobilizamos neste estudo comparativo. Não é, todavia, este o local onde iremos explorar a questão.

\section{Marco teórico}

Os espaços públicos comerciais são extremamente potentes do ponto de vista das dinâmicas urbanas por serem locais de circulação, de criações e de trocas, tanto materiais quanto simbólicas, efetivadas por meio de pessoas, de produtos e de imagens (Lefebvre, 1999). Com a crescente diversificação e especialização dos serviços nos últimos séculos, edifícios-galeria, ruas comerciais e shopping centers coexistem no espaço, favorecendo as dimensões comerciais das cidades, proporcionando a constante recriação de centralidades, de distintas formas físicas e sociais.

Cada vez mais as transformações no comércio e os seus impactos nas vivências cotidianas e nos processos de displacement são relevantes para pensar a gentrificação. Profundamente vinculado a essa histórica dimensão das cidades, o processo de gentrificação, tradução portuguesa do termo gentrification (do inglês gentry, pequena nobreza) foi assim cunhado pela socióloga britânica Ruth Glass, em 1964, a partir de um de seus estudos de Londres, associando múltiplas questões como sociabilidade, espaço público e especulação imobiliária, apesar de ser comumente reduzido a uma ideia de enobrecimento urbano. Desde então, a gentrificação tornou-se uma estratégia urbana global (Smith, 2002).

O processo é geralmente marcado por um conjunto de tensões que atuam de forma concomitante em uma mesma centralidade, ampliando o potencial das forças capazes de destruir os conteúdos ali reunidos. Ou seja, é um fenômeno cujas forças são suficientemente potentes para romper as tradicionais práticas de sociabilidade, de trocas materiais 
e simbólicas e para ameaçar o direito à cidade, especialmente a um conjunto majoritário que é considerado como minoria do ponto de vista dos capitais financeiros e simbólicos. A gentrificação identifica-se também pela presença crescente de práticas globais de consumo, de homogeneização de paisagens comerciais e de relações de sociabilidade que excluem populações que não têm acesso ao novo padrão de consumo ou instrumentalizam a sua presença, enquanto sinal de "autenticidade", conforme sugere BrownSaracino (2004).

Os espaços comerciais aqui analisados, que não são locais de transações econômicas apenas, são espaços sociais onde práticas de sociabilidade urbana são formadas, aprendidas e reproduzidas. Cada local de compras cria sua própria identidade aninhada à percepção de que o mercado é uma cidade, dentro da cidade (Zukin, 2012). Uma vez que, deliberada ou silenciosamente, nestes espaços coexistem cotidianamente tensões que revelam tanto as relações dialéticas entre local versus global quanto os processos de gentrificação e resistência, o mesmo se torna especial objeto de pesquisa. Consideramos que a resistência à gentrificação se compõe não só de oposição declarada, mas também de resistências cotidianas. É a estas últimas que aqui nos dedicamos. Trata-se de formas de resistência muitas vezes invisíveis que se consubstanciam na continuidade da presença e de práticas do dia-a-dia ligadas a uma realidade que antecede a lógica da regeneração urbana e profundamente enredadas no contínuo processo de transformação a que os espaços urbanos estão sujeitos (Lees, Annunziata e RivasAlonso, 2017; Giroud, 2007).

As dinâmicas e tendências associadas aos processos de gentrificação comercial sublinham as contradições presentes na produção e reprodução das trocas materiais e simbólicas, concretizadas por meio de pessoas, de produtos e de imagens. Neste sentido, há que se considerar que essas transformações de espaços comerciais impactam nas relações sociais que aí se efetivam, pois o processo de 
gentrificação acaba por exercer um "filtro social" e passa a integrar um processo de acumulação de capital, com seus respectivos movimentos cíclicos de fluxos de circulação (Mendes, 2014).

Nosso argumento principal está alinhado ao pressuposto de que tais dinâmicas e tendências colocam em xeque a capacidade desses espaços serem o suporte e fazerem parte da construção de uma sociabilidade urbana plural e inclusiva: processo que é produzido e reproduzido cotidianamente por meio da pequena escala de interações sociais; pelo enraizamento da propriedade individual das mais variadas lojas; pelo caráter dos produtos comercializados; pelas tradicionais negociações culturais que acontecem entre lojistas e clientes habituais; além de dois fundamentais princípios da vida urbana - "familiaridade e estranheza" (Zukin, 2012). A gentrificação comercial, não raramente associada a processos de gentrificação residencial, rompe com as lógicas referidas anteriormente, impactando a vida cotidiana dos utilizadores das áreas em causa e provocando pressões indiretas de expulsão das populações residentes no entorno (Gant, 2015). São as características múltiplas dos espaços comerciais urbanos e suas tantas transformações que visamos analisar a partir dos casos escolhidos como objeto.

\section{Metodologia}

O método etnográfico, eleito para esta pesquisa, tem a vantagem de evitar aquela dicotomia que opõe o indivíduo e as megaestruturas urbanas, pois a perspectiva de análise "de perto e de dentro" é capaz de apreender os padrões de comportamento, múltiplos e heterogêneos, os grupos, as redes e os sistemas de troca (Durhan, 1986 Magnani, 2002; 2014). 
Voltado para os processos do cotidiano, seguindo os atores sociais e dialogando com eles em suas escolhas e arranjos em suas interações sociais usuais, em seus modos de vida. Tal estratégia depende da potencialidade de estranhamento, do insólito, da experiência, da necessidade de examinar por que alguns eventos, vividos ou observados, nos surpreendem. Em geral, as etnografias cumprem, pelo menos, três condições: i) consideram a comunicação no contexto da situação; ii) transformam, de maneira feliz, para a linguagem escrita o que foi vivo e intenso na pesquisa de campo, transformando experiência em texto; e iii) detectam a eficácia social das ações de forma analítica. Associadas à etnografia, entrevistas serão realizadas também com o propósito de interpretar os significados subjetivos. Essa prática, desde a elaboração do seu instrumento (roteiro) delineia perguntas que estimulem a reflexividade e a narratividade, renuncia às reivindicações de neutralidade dos dados obtidos e reconhece que o processo de validação passa pela contextualização das situações sociais em que são produzidos.

Os exercícios de interpretação apoiados na dupla vertente, pensamento e ação, e nas finalidades de conscientização e dialética da investigação sobre o conjunto dos fenômenos observados, conferem à investigação etnográfica uma intencionalidade própria: a interpretação e a crítica. Sendo que o pressuposto da totalidade, nesta investigação científica, seguirá os pressupostos de Magnani:

(...) posto que não se pode contar com uma totalidade dada, postula-se uma, nunca fixa, a ser construída a partir da experiência dos atores e com a ajuda de hipóteses de trabalho e escolhas teóricas, como condição para que se possa dizer algo mais do que generalidades e platitudes a respeito do objeto de estudo. (Magnani, 2009, p.137).

Portanto, por esta via, as análises deste trabalho recaíram predominantemente sobre as atuais atividades comerciais, o cotidiano vivenciado em seus espaços, seus principais usuários e suas trocas materiais e simbólicas. 


\section{Análises e discussões de dados}

O Mercado Central de Belo Horizonte, localizado nesta área central, foi inaugurado em 1929 para suprir as necessidades de abastecimento da cidade e, desde então, se tornou uma referência para a população local e regional. Com efeito, sua história está associada à própria história da cidade e configura, há décadas, um ponto importante de turismo regional, nacional e até mesmo internacional. Caracterizase por uma "mistura de religiosidade, cultura popular e tradição pela variedade de produtos existentes e que vai de verduras, frutas, ervas a utensílios domésticos, artesanato e artigos religiosos"2.

Neste sentido, o Mercado Central releva, de modo peculiar, alta capacidade de polarizar fluxos, atraí-los ou dispersá-los, concentrar e aproximar, ao menos fisicamente, uma vasta diversidade de pessoas e atividades. Ao mesmo tempo, consoante ao movimento dialético, tal espaço é capaz de exibir as forças presentes na centralidade que são capazes de destruir, estilhaçar e até mesmo solapar os conteúdos ali reunidos.

Ao longo de mais de um século o Mercado passou por múltiplas fases em que seu potencial de centralidade foi colocado à prova, pelas próprias tendências e dinâmicas capitalistas associadas ao comércio e abastecimento de gêneros alimentícios. Especialmente a partir da década de 1980 destaca-se a presença dos grandes hipermercados e dos shoppings centers que inauguravam um novo estilo de compras e de relação entre cliente e comerciante. Para enfrentar estes desafios, tal espaço físico suportou várias e sucessivas obras de expansão e de adequação, o que gerou, como consequência, uma série de ajustes e adaptações das lojas e dos produtos comercializados, mantendo, no entanto, sempre suas principais características em termos de produtos, formas de comercialização e de sociabilidade.

2 A este respeito, sugerimos ver os seguintes sites: https://bit.ly/2JrYKUi. 
De forma mais intensa, nos últimos anos, assiste-se a um gradual processo de transformação de suas atividades. Além dos referidos espaços, marcadamente mais tradicionais, somam-se alguns novos estabelecimentos de usos peculiares como uma casa lotérica, salões de beleza, lojas de produtos alimentícios japoneses, uma loja das sandálias Havaianas, uma ótica e saltam aos olhos um conjunto de 9 lojas de suplementos alimentares, atendendo à moda fitness.

A presença de lojas de franquia com fins diversos, como casas Lotéricas, Havaianas, Empada de Minas e a inserção de atividades que não têm vínculos diretos com os tradicionais usos do mercado, como as lojas de produtos e suprimentos de informática, lojas de produtos indianos e de alimentos japoneses indiciam uma prática de comercialização de produtos indiferenciados que podem ser encontrados em qualquer outro shopping do país. Essas lojas se caracterizam não só pelo produto, mas também por um formato de relação com o cliente que rompe com as tradicionais trocas simbólicas, como a pechincha. Assim, este processo retira do Mercado a sua marca simbólica de lugar das trocas materiais locais e regionais, de produtos muitas vezes manufaturados e com uso de insumos (alimentos, madeiras, minerais) das diversas regiões do estado de Minas Gerais. Ou seja, notadamente interfere em uma característica histórica do Mercado que é o fato de ser um lugar de referência para a compra de um conjunto de mercadorias peculiares à cultura local, comercializadas de uma forma determinada e apresentações específicas, o que daria real singularidade ao Mercado. 
Foto 01: Detalhe de banca de pimenta, em uma típica loja de legumes e verduras no Mercado

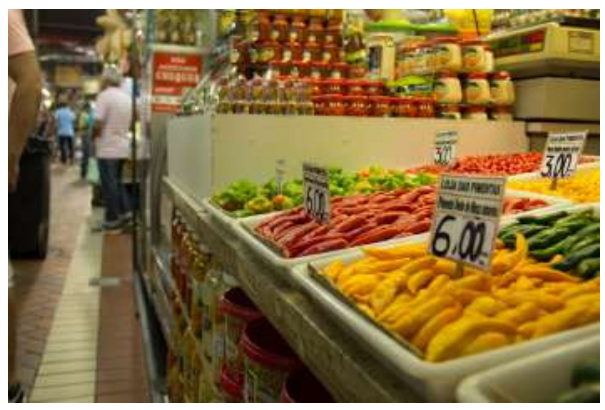

Fonte: autores.

Foto 02: Vista de uma típica loja de utensílios domésticos no Mercado

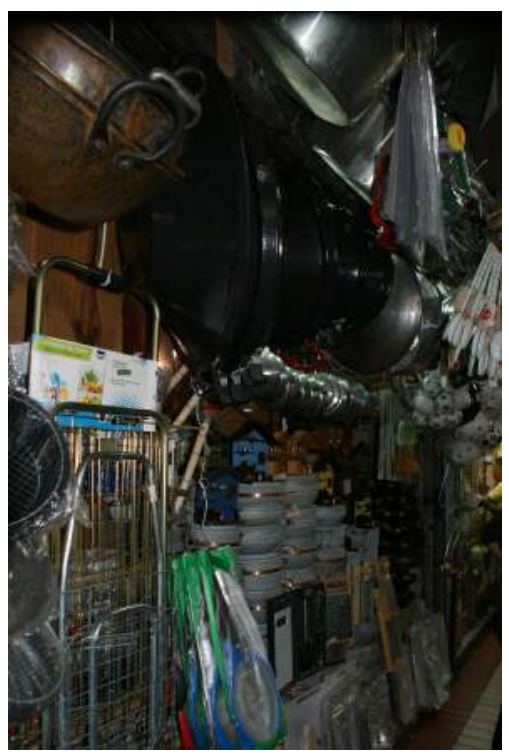

Fonte: autores. 
Foto 03: Detalhe de loja tradicional de bebidas

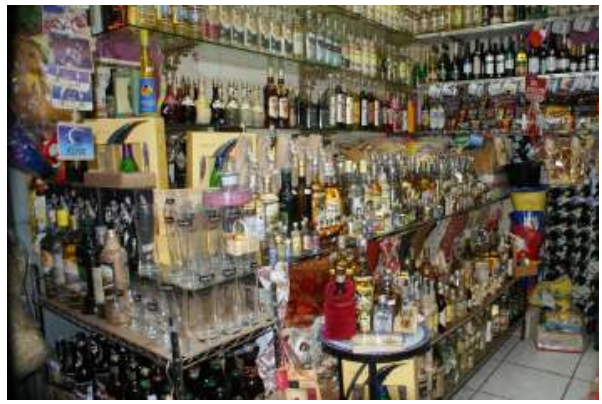

Fonte: autores.

Foto 04: Vista de uma Loja Havaianas

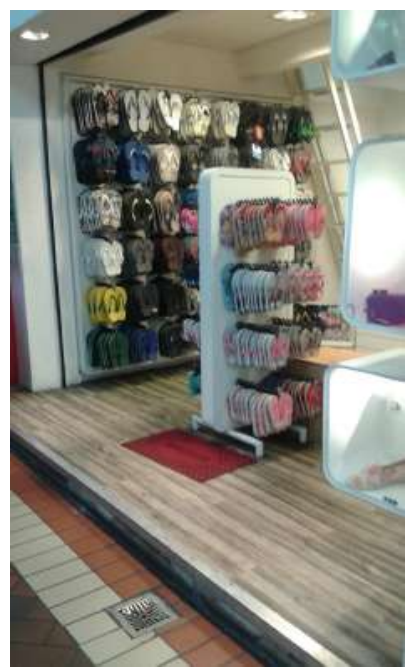

Fonte: autores. 
As novas tipologias de lojas configuram novos usos e, consequentemente, são atraídos novos públicos, que confirmam o potencial deste espaço para o entrecruzar de vários fluxos, contudo, faz-se notória a crescente perda de espaço dos diversos e tradicionais produtos que legaram ao Mercado o atributo de "patrimônio cultural mineiro".

Foto 05: Detalhe de nova queijaria recentemente implantada, com venda de cervejas artesanais

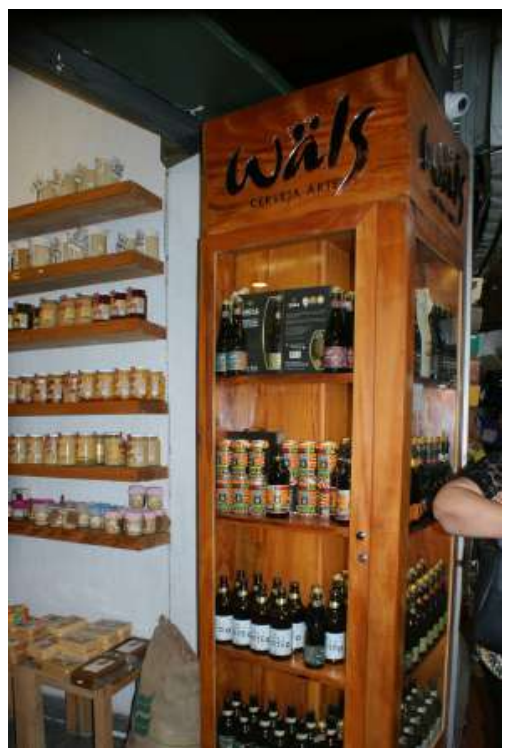

Fonte: autores. 
Foto 06: Detalhe de nova padaria recentemente implantada

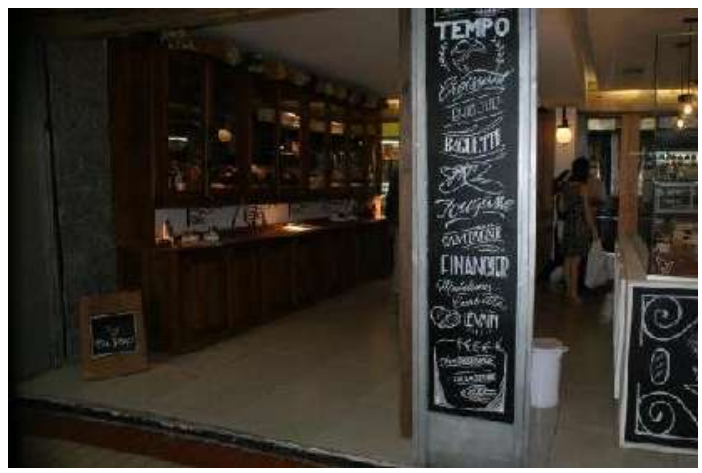

Fonte: autores.

Logo, somam-se um conjunto de novos estabelecimentos especialmente queijarias, cachaçarias, cafés e padarias, a exemplo da "Padaria Du Pain" e "Roça Capital: Armazém Mineiro", que revelam tendências à gentrificação, seja pela gourmetização dos produtos que reforça o "consumo da cultura", pela "destradicionalização" de determinados conjuntos de práticas associadas ao hábito alimentar ou pela tendência a estabelecer um padrão seletivo de clientes.

O caso do Mercado Central, em particular, distingue-se das práticas recorrentes de gentrificação, pois não há uma política pública ou uma ação coletiva concertada que vise promover alterações substanciais no espaço. É então imperioso acompanhar esse processo, pois se configura como um fenômeno disperso que, sem muito alarde, aos poucos, poderá trazer sérias consequências do ponto de vista da preservação de um patrimônio cultural. De modo similar ao já estudado por Viana Cerqueira (2014), no caso das ruas de Paris, as novas lojas do mercado central, diversificam e associam múltiplas práticas e padrões culturais que se tornam cada vez mais complexos. 
O segundo estudo de caso está localizado em Brasília, cidade que foi inaugurada em 1961, um marco no planejamento urbano e regional brasileiro, cujo projeto urbanístico, concebido por Lúcio Costa, tinha como missão, em seu discurso oficial, expandir o mercado nacional e promover a ocupação da região centro-oeste.

Entretanto, o crescimento de Brasília se deu a partir das chamadas cidades satélites que se configuravam como cidades-dormitório e áreas invadidas gravitando ao seu redor, uma vez que seu projeto não incluía justamente todos os migrantes, especialmente os trabalhadores da construção civil, de menor poder aquisitivo. Entre 1960 e 1980 a cidade cresceu em função da migração sendo que, entre os anos de 1984 e 1998, há um incremento de mais de 50\% da área urbana, com consequências urbanas e ambientais. (Ribeiro e Holanda, 2015). Assim, a cidade de Brasília, desde seu original projeto, é marcada pelas desigualdades socioespaciais que se reproduzem e reforçam as assimétricas relações de poder e de dominação de cariz econômico, social e cultural.

Um dos elementos urbanísticos mais singulares do projeto do plano é a superquadra, voltada à escala residencial tendo como apoio as escalas bucólica e gregária. Em cada superquadra, seus componentes morfológico, tipológico e ambiental, na concepção do próprio Lúcio Costa, possibilita a "reaproximação do habitante com o seu lugar de morada, reconectando aspectos bucólicos às edificações a partir de uma relação do ambiente construído com os espaços circundantes, livres e arborizados (...)" (Magalhães, 2015, p.12). Além disso, em cada quadra há uma área comercial, originalmente com o propósito de abrigar a diversidade de comércios e serviços que atendessem aos moradores do entorno imediato.

O projeto original do plano piloto previa que os blocos residenciais das quadras 100, 200 e 300 fossem de seis pavimentos, enquanto, os blocos das quadras 400 , em razão da proximidade do Lago Paranoá, seriam de até três pavimentos, com ou sem pilotes, sem a obrigatoriedade de garagens e de elevadores, portanto, uma tipologia mais econômica. 
Logo, desde o projeto da cidade, as quadras 400, especialmente as residenciais, se dirigiam a um público de menor poder aquisitivo quando comparado aos das quadras $100 \mathrm{e}$ 200 , configurando já, a priori, configurações espaciais que criam demarcações físicas e simbólicas.

No caso dos comércios locais, há diferenças marcantes em sua configuração quando comparamos as soluções adotadas para Asa Sul e Asa Norte, pois os da Asa Sul, em geral, obedeciam a uma tipologia uniforme, semelhante nas diversas quadras, já os blocos comerciais da Asa Norte adotaram uma tipologia mais diversificada.

Nosso objetivo de análise recai sobre as dinâmicas de transformação urbana nas quadras residenciais e comerciais 412/413 e 213/214, da Asa Norte, decorrentes especialmente da implantação do Parque Olhos d'Água, na década de 1990.

A hipótese é que este fato potencializou a dinâmica de especulação imobiliária residencial e comercial no entorno e vem provocando nas quadras comerciais 412/413 uma concentração homogênea de estabelecimentos ligados à alimentação - mercados orgânicos, padarias, cafeterias, restaurantes - dirigidos a um perfil de consumidor bastante determinado, altamente capitalizado ou a ele vinculado, e a um modelo "gourmetizado" de serviço. Esta dinâmica é observada, primeiro, pela construção recente de dois novos blocos comerciais da quadra, e, segundo, pela implantação de lojas bastante peculiares: a Colaborativa (mercearia), a La Boutique (padaria), o Clandestino (espaço de café e música), a Houston (hamburgueria), o Cookers Cozinha Criativa (café e restaurante lounge). Estes empreendimentos comerciais somam-se aos mais antigos restaurantes da Quadra - Santé, El Negro e Dona Lenha - configurando uma espacialidade altamente homogênea quando comparada aos padrões usuais das demais quadras comerciais de Brasília. 
238 • Segregación socio-espacial en las ciudades latinoamericanas

Foto 07: Vista de bloco de construção mais recente na Quadra CLN 412/413

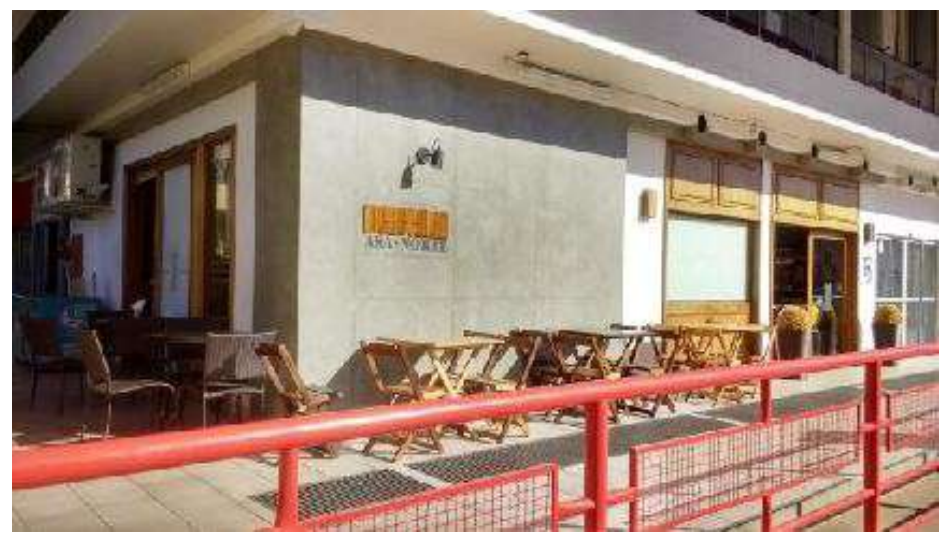

Fonte: autores.

Foto 08: Detalhe das lojas na Quadra CLN 412/413

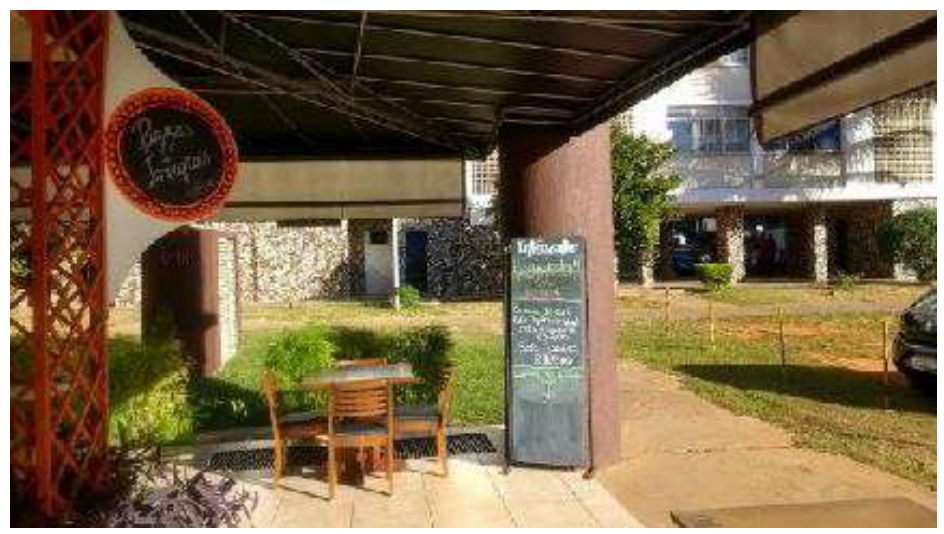

Fonte: autores. 
Já as quadras comerciais 213/214 revelaram uma maior resistência aos processos de enobrecimento de suas atividades e clientela, mantendo a diversificação de atividades e serviços mais gerais, o que se aproxima dos modos de uso e ocupação original do projeto da cidade e que ainda estão vigentes nas múltiplas opões de serviço encontradas nas demais quadras comerciais desta Asa. Vale ressaltar, entretanto, que há indícios de dinâmicas da gentrificação, por exemplo, pelo fato de o Banco do Brasil implantar nesse local uma agência de atendimento a clientes mais capitalizados financeiramente, conhecidas como "Agência Estilo". Com efeito, quando se observa o recente padrão de uso e ocupação dos novos edifícios residenciais construídos nos últimos cinco anos, nas adjacências dessa área comercial, verifica-se, pelo padrão da tipologia arquitetônica, o predomínio da produção de moradia para classes altamente capitalizadas.

Foto 09: Vista de blocos na CLN 213/214 com serviços tradicionais e diversificação comercial

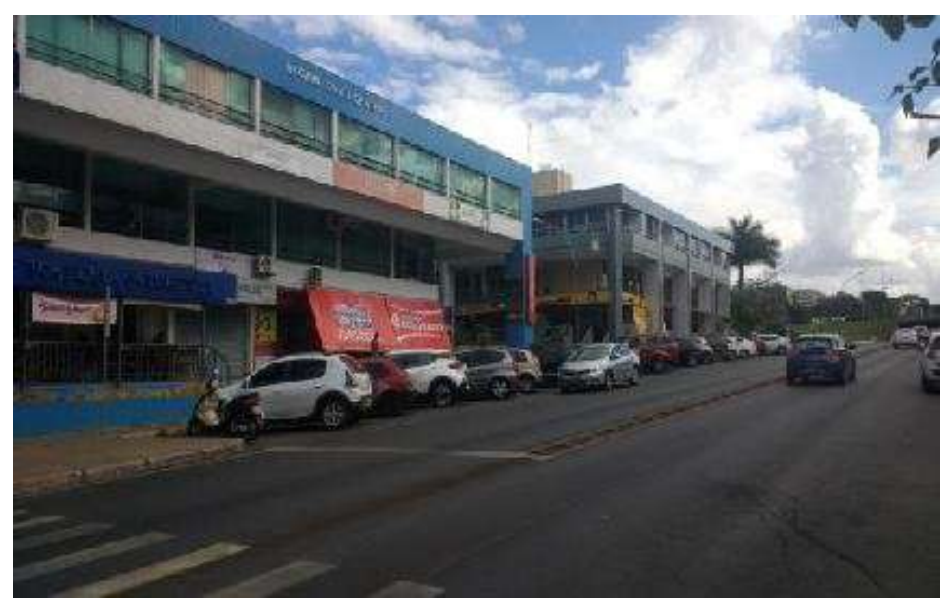

Fonte: autores. 


\section{Foto 10: Vista de blocos na CLN 213/214 com serviços tradicionais e diversificação comercial}

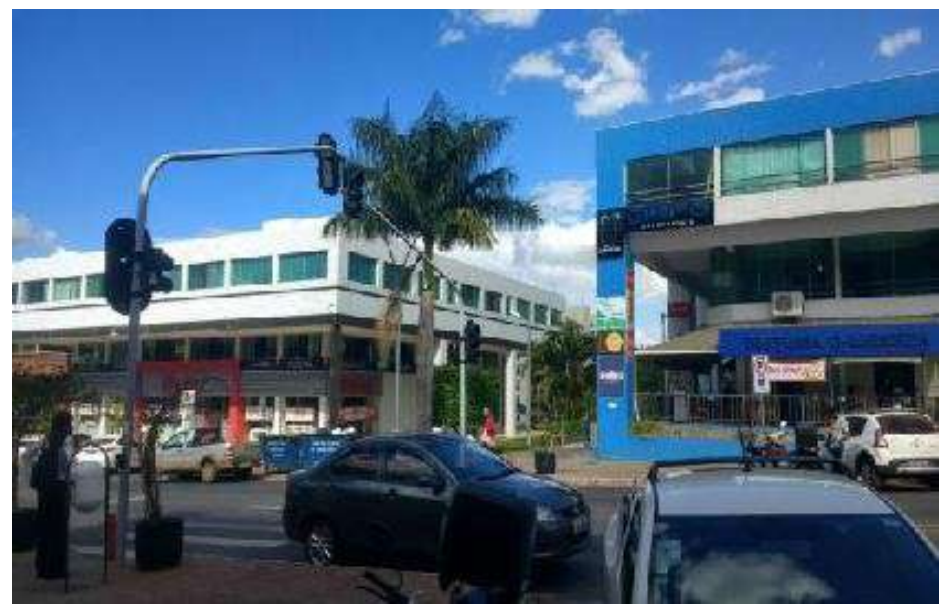

Fonte: autores.

Em Lisboa, até recentemente, o processo de gentrificação no centro histórico era, sobretudo, o que se apelida de "gentrificação marginal" (Rose, 1984). O patrimônio imobiliário vinha a degradar-se desde os anos 1980: o congelamento dos aluguéis e os elevados custos associados à reabilitação promoveram o abandono de muitos edifícios e sua consequente desvalorização. Os censos de 2011 mostram um abrandamento da tendência de perda populacional da cidade iniciada na década de 70 e estudos qualitativos mostram que alguns bairros do centro histórico, como Alfama (Costa, 1999) e o Bairro Alto (Mendes, 2006, Pavel 2015) atraíram, sobretudo nos anos 90 e início do século XX, pequenos grupos de novos residentes oriundos das classes médias urbanas.

Em Alfama, a reabilitação urbana não foi imediatamente acompanhada de um processo de gentrificação: "Outros fatores, como os que se têm vindo a analisar, cruzaram-se 
com este, dando ao conjunto do processo uma feição geral não gentrificadora, se bem que recheada de contraexemplos e soluções ambivalentes, e mantendo, também, uma grande margem de indeterminação quanto ao futuro" (Costa, 1999, p. 442). Mendes e Pavel (Mendes 2014, Pavel 2015) apontam o início dos anos 2000 como momento de viragem neoliberal das políticas de reabilitação urbana no país e mais especificamente na cidade de Lisboa. Esta nova direção das políticas tem vindo a facilitar os processos de gentrificação em curso.

A partir de 2008, com a crise econômica, parte significativa do investimento imobiliário foi sendo desviado dos grandes empreendimentos suburbanos, para a reabilitação do centro, em especial no segmento de luxo. Neste ponto interessa convocar para a análise a rent gap theory de Neil Smith (1996). A crise surgiu como oportunidade para implementar uma política de cidade neoliberal que inclui, por parte de agentes públicos, a promoção turística agressiva e incentivos às chamadas classes criativas e a potenciais investidores nacionais e internacionais. A dinâmica do mercado imobiliário, resultante destes e outros fatores, é essencial para compreendermos os fenômenos de transformação urbana a que assistimos hoje nesta área de Lisboa. Segundo dados recentemente divulgados pela Confidencial Imobiliário $^{3}$, os aluguéis na cidade de Lisboa têm tido um aumento considerável nos últimos anos; a oferta de venda de casas tem diminuído e os preços aumentado. As expulsões são consequência desta combinação de fatores e uma realidade hoje impossível de negar.

É neste contexto que analisamos a área em torno das ruas Poço dos Negros, Poiais de S. Bento. Situadas entre a Bica e a Madragoa, e historicamente ligadas ao trabalho e

3 A Confidencial Imobiliário produz e vende dados estatísticos sobre preços de transação e contratos de arrendamento de imóveis residenciais com vista a responder às necessidades de informação dos operadores de mercado, seja na decisão sobre investimentos, seja na ação comercial.

(www.confidencialimobiliario.com). 
aos trabalhadores do porto e das embarcações, mas também da pequena indústria (Alcântara, 2013), essas ruas foram, até recentemente, uma referência espacial para populações oriundas de Cabo Verde (Malheiros, 1998; Pereira, Raposo e Alves, 2004).

A herança portuária, a decadência do edificado e a presença de atividades ligadas ao tráfico de droga e de populações estigmatizadas como imigrantes, prostitutas e população em situação de rua, atribuiu a esta área, e a outras adjacentes como o Cais do Sodré, uma forte imagem externa negativa que durou as últimas décadas do século XX. Mesmo nessa época, a área logrou manter a atividade comercial - embora com menos vigor - a cujo declínio assistimos na transição do século.

As razões apontadas pelos residentes e comerciantes locais para este fenômeno são diversas: a abertura de supermercados como o Minipreço, a atuação da $\mathrm{ASAE}^{4}$ que obrigou ao encerramento de mercearias que não correspondiam aos novos padrões de higiene e segurança, a abertura do Metrô do Chiado que desviou todos os potenciais compradores. A estas acrescentamos o declínio da atividade portuária desde meados dos anos 80, o consequente desaparecimento de postos de trabalho e diminuição da população residente, também relacionada com as más condições de habitabilidade e com os processos de suburbanização e metropolização de Lisboa.

No início do século XXI, discernia-se ainda, na paisagem comercial da área, a forte presença de população africana, sobretudo cabo-verdiana, apesar de esta nunca ter sido majoritária entre os residentes e de estar já em franco declínio. Dos vários restaurantes, tascas, bares e lojas, cujos proprietários e muitos clientes eram oriundos do arquipélago, restam hoje um restaurante na Rua Poço dos Negros e outro na Rua da Silva. A porta fechada do restaurante Taki Tala é um marco dessa

\footnotetext{
4 ASAE (Autoridade de Segurança Alimentar e Econômica).
} 
presença, que passa facilmente despercebido. Podemos aqui invocar a noção de discursive displacement (Holgersson, 2014), que resulta de alterações estéticas e simbólicas do ambiente urbano e do edificado, que forçam a invisibilidade de determinadas populações ou heranças urbanas: deixam de fazer parte das narrativas e imagens do lugar, a não ser por vezes de forma estetizada.

\section{Foto 11: Porta do Taki Tala}

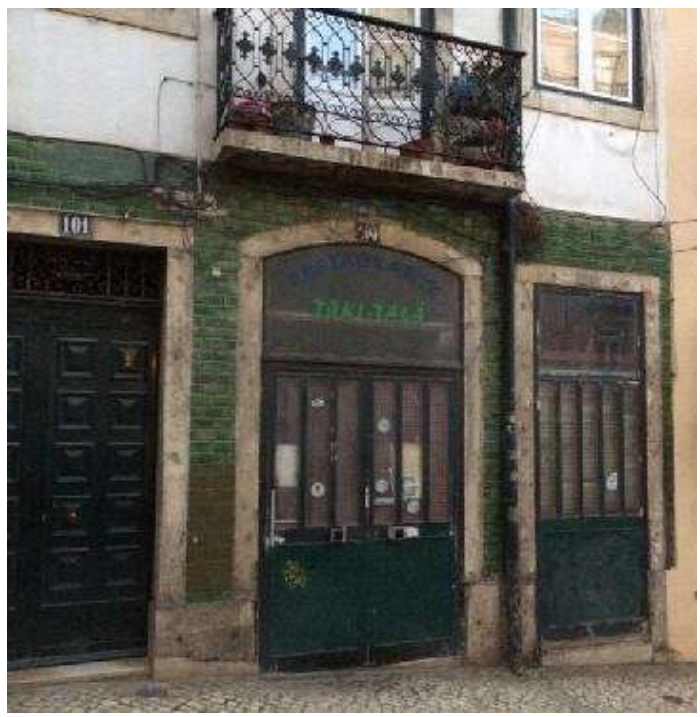

Fonte: autores. 


\section{Foto 12: Pólo Cultural Gaivotas}

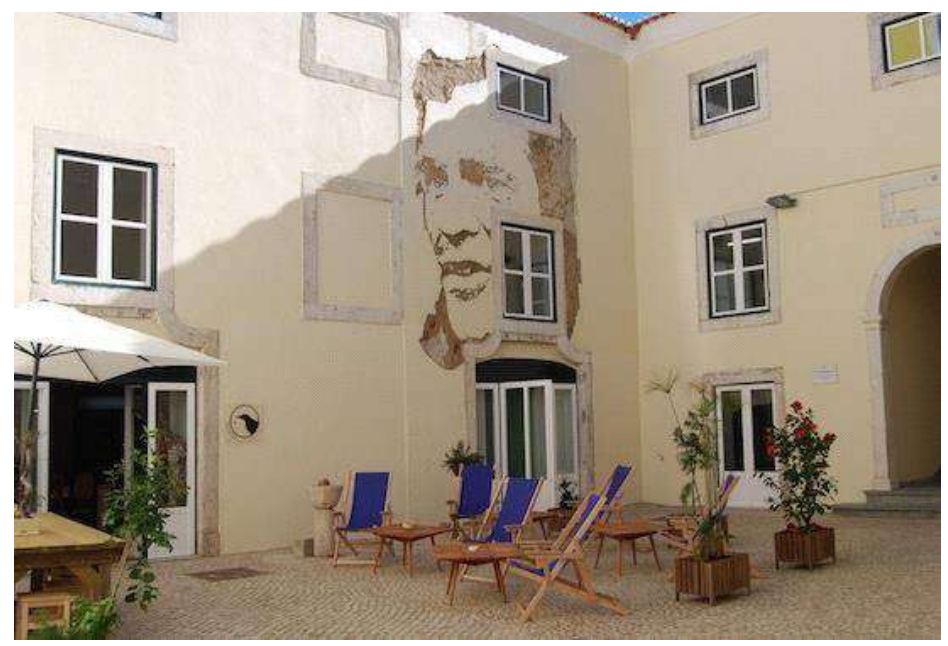

Fonte: autores.

$\mathrm{Na}$ mesma época, promotores imobiliários começam a reabilitar dois antigos palácios devolutos: o Palácio Flor de Murta, que foi transformado em estúdios, em 2004, mas conheceu à época dificuldades de comercialização, e o Palácio Mesquitela, cujo projeto se iniciou em 2002, mas apenas recentemente foi comercializado. Também na virada do século, assistimos à chegada de residentes ligados às artes juntando-se a uma mão cheia de pioneiros - e de estruturas artísticas ditas "alternativas", como a companhia teatral Cão Solteiro em 1997 e o Atelier Real em 2005. O fluxo de novos residentes continuou associado a agentes do campo artístico. Em 2015, o Teatro Praga instalou-se numa parte da Escola da Rua das Gaivotas e, em 2016, a Câmara Municipal inaugurou aí um Polo Cultural. Em entrevista, um residente procura explicar esta dinâmica, na qual participa: 
Portanto, a rua sempre teve uma mistura e hoje aquilo que tu vês, imensa gente que ou é de Cabo Verde, ou é brasileira ou é chinesa. Teve até aos anos 90 uma vida qualquer muito multicultural e que é uma herança histórica. Depois a partir daí eu acho que ela está estagnada, essa população é toda muito envelhecida, depois quando eu vim, eu moro aqui há cerca de 10 anos, quando eu vim havia muitos artistas, muita gente nova porque era uma rua que estava a ser modificada numa artéria próxima do centro, mas não havia mesmo barulho e, portanto, existiam muitos artistas e a partir daí não sei o que é que aconteceu, se foram os artistas ou não, nós também começamos a fazer uma série de coisas [...] (Tomé, morador, 2016)

Foi a partir de 2013, que a crescente especulação imobiliária no centro histórico, o programa municipal BIP ZIP e o crescimento da atividade turística em Lisboa, entre outros fatores, ditaram uma transformação profunda da dinâmica comercial, cultural, residencial e dos espaços públicos desta área.

No que respeita às recentes e profundas transformações no comércio local na Rua Poço dos Negros e circundantes, a tendência é para o encerramento de lojas antigas cujos produtos e serviços são de uso cotidiano, a estagnação da clientela de muitas das que ficam abertas - excetuando alguns cafés e restaurantes - e a abertura em catadupa de novas lojas com produtos design e gourmet/tradicionais/ autênticos e cafés/restaurantes, muitas vezes temáticos. $\mathrm{Na}$ primeira categoria relevamos o encerramento da drogaria no no 109 da Rua Poço dos Negros 2016, e da mercearia no $n^{\circ} 105$ em 2015, ambas bastante antigas. Outros lojistas antigos revelaram, durante o trabalho de campo, receio ou mesmo vontade de fechar portas, sobretudo devido à falta de clientes, como a ervanária, o fotógrafo ou o oculista, que veio a fechar. Encerrou também portas em 2016, a Livraria Avellar e Machado (no no 19), "o mais antigo alfarrabista de Lisboa”, devido ao aumento de aluguel. Mantêm-se com clientela e movimento, por exemplo, os restaurantes Zapata e 
Tambarina, e a pastelaria Nita, na Rua Poço dos Negros. Ao contrário de outros estabelecimentos na zona, estas casas parecem resistir às mudanças e beneficiar do afluxo de novos visitantes e residentes. Elencamos, por outro lado, a abertura muito recente de vários cafés para uma clientela de classe média (sobretudo jovem) e turistas, de uma loja de chás e um salão de chá, todos na Rua Poço dos Negros. Ainda no campo da nova restauração, encontramos na zona duas mercearias gourmet, uma aberta há já alguns anos e outra há poucos meses, dois estabelecimentos de pastelaria francesa, uma pastelaria de bolos caseiros, uma loja de empadas e bolos argentinos. Na Rua Poiais de S. Bento, menos dedicada à comida e bebida, encontramos várias lojas roupa, arte e design, como a +351 e a Apaixonarte. A arquitetura e o design têm também uma presença forte na área, com vários ateliers e espaços de co-work.

\section{Foto 13: Oculista, R. Poço dos Negros}

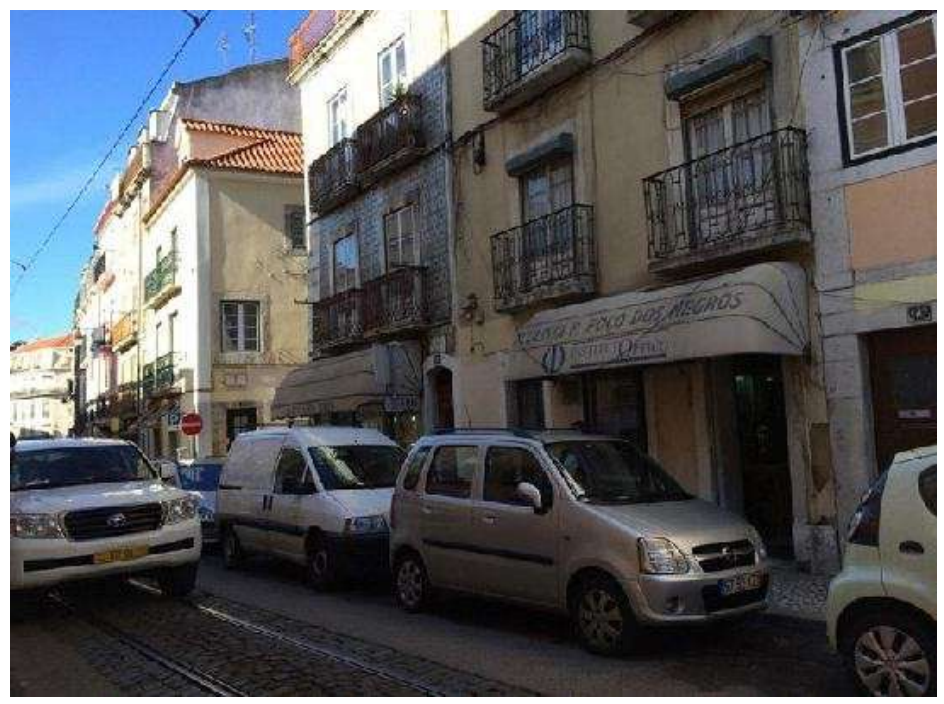


Apesar dos fluxos crescentes de turistas nesta zona próxima ao Cais do Sodré e Bairro Alto (polos de grande atração), a dinamização do comércio é ainda uma preocupação local, quer por parte dos antigos, quer dos novos comerciantes, que se juntam em mais de uma iniciativa: Feira Vizinha e Triângulo Aberto, organizadas por grupos diferentes de comerciantes.

\section{Conclusões: notas sintéticas}

Este texto marca o início de um trabalho de pesquisa comparativo a três mãos que, partindo da análise da mudança do comércio, visa contribuir para pensar a gentrificação à escala global, analisando tendências semelhantes e diferenças associadas ao contexto local no Brasil e em Portugal. Uma das tendências comuns mais interessantes que registramos nos três casos, e que procuraremos aprofundar no futuro, é a coexistência ao longo do processo, de elementos de transformação, por um lado, e de permanência ou resistência, por outro. Se alguns comércios mais antigos não conseguem sobreviver face às pressões de mudança, outros se mantêm abertos, logrando alguns desses adaptar-se à procura atual, utilizando o potencial comercial da "autenticidade".

De modo exemplar o Mercado Central é uma cidade dentro da cidade, um lugar que exprime formas materiais e simbólicas de elaborar os modos de vida. Na etapa em que se encontra o trabalho de campo já é possível identificar tendências múltiplas que vão desde a reificação de determinadas leituras da identidade local, até a ressignificações de patrimônios culturais imateriais, como o queijo mineiro e a cachaça de alambique, com um viés bastante gourmetizado. Somadas à presença de novos estabelecimentos vinculados a redes e franquias, que exprimem as dinâmicas locaisglobais. Já Brasília revela nas reconfigurações específicas 
das quadras comerciais aqui analisadas tendências associadas às práticas globais de consumo, alterações nos padrões de sociabilidade e homogeneização de paisagens comerciais e residenciais. No caso de Lisboa, sugere-se que estamos perante um fenômeno de gentrificação residencial e comercial que envolve a transformação física, simbólica e social: a reabilitação dos edifícios; alteração substantiva da paisagem comercial e cultural e das vivências urbanas. Assistimos também à substituição de populações locais residentes, trabalhadoras e utilizadoras por novos residentes com poder aquisitivo superior (residentes permanentes e temporários, mas também lojistas, trabalhadores e turistas). Fica clara a pressão de expulsão sentida por algumas populações e o discursive displacement das populações imigrantes e trabalhadoras da área, assim como a estetização dos elementos físicos associados à sua presença, substituídos pela nova narrativa em torno das artes performativas e do design.

\section{Bibliografia}

Alcântara, A.. Uma geografia da Lisboa operária em 1890. I Congresso de História do Movimento Operário e dos Movimentos Sociais em Portugal. Lisboa, 2013.

Araujo, E.; Caldeira; J.; Oliveira, L. Superquadras 400 Sul: habitação social no plano piloto de Brasília. Brasília: Editora Kiron, 2015.

Bernt, M. Very particular, or rather universal? Gentrification through the lenses of Ghertner and López-Morales. City, 20 (4), pp. 637-644, 2016.

Brown-Saracino, J. Social Preservationists and the Quest for Authentic Community. City and Community, 3 (2), pp. 135-156, 2004.

Cerqueira, E. D. V. A evolução das formas de gentrificação: estratégias comerciais locais e o contexto parisiense. Cadernos Metrópole, 16 (32), pp. 417-436, 2014. 
Costa, A. F. Sociedade de bairro: dinâmicas sociais de identidade cultural. Oeiras: Celta, 1999.

Gant, A C. Tourism and commercial gentrification. The ideal city. Between myth and reality. RC21 International Conference. Urbino, 27th-29th August, ISA. PDF, 2015.

Ghertner, D. A. Why gentrification theory fails in 'much of the world'. City, 19 (4), pp. 552-563, 2015.

Glass, R. Introduction. In: Glass, Ruth. London: aspects of change. London: MacGibbon \& Kee, pp. xiii-xiii, 1964.

Holanda, F. de; Ribeiro, R. J. da C. A Metrópole de Brasília na rede urbana brasileira e configuração interna. In: Holanda, F.; Ribeiro, R.; Tenório, S. (orgs.), Brasília: transformações na ordem urbana. Rio de Janeiro: Letra Capital, 2015.

Holgersson, H. Post-Political Narratives and Emotions: Dealing with Discursive Displacement in Everyday life. In: Jackson, E.; Jones, H. (eds.), Stories of Cosmopolitan Belonging: Emotion and Location. Milton Park: Routledge Earthscan, 2014.

Jayme, J.; Trevisan, E. Intervenções urbanas, usos e ocupações de espaços na região central de Belo Horizonte. Civitas-Revista de Ciências Sociais, 12 (2), pp. 359-377, 2012.

Lees, L.; Annunziata, S.; Rivas-Alonso, C. Resisting Planetary Gentrification: The Value of Survivability in the Fight to Stay Put. Annals of the American Association of Geographers (online first), 2017.

Lefebvre, H. A revolução urbana. Belo Horizonte: Editora UFMG, 1999.

Lemos, C. B. Determinações do espaço urbano: a evolução econômica, urbanística e simbólica do centro de Belo Horizonte. Dissertação de Mestrado em Sociologia - Faculdade de Filosofia e Ciências Humanas, Universidade Federal de Minas Gerais, Belo Horizonte, 1998.

López-Morales, E. Gentrification in the Global South. City 19 (4), pp. 564-573, 2015. 
López-Morales, E.; Shin, H. B.; Lees, L. Latin American gentrifications. Urban Geography, 37 (8), pp. 1091-1108, 2016.

Magalhães, A. Apresentação. Instituto do Patrimônio Histórico e Artístico Nacional (Brasil). Superintendência do Iphan no Distrito Federal. Superquadra de Brasília: preservando um lugar de viver. IEPHA: Brasília, 2015.

Magnani, J. G. C. De perto e de dentro: notas para uma etnografia. Revista Brasileira de Ciências Sociais, 17 (49), pp. 11-29, 2002.

Malheiros, J. Minorias Étnicas e Segregação nas Cidades: uma aproximação ao caso de Lisboa, no contexto da Europa mediterrânica. Finisterra: Revista Portuguesa de Geografia, 33 (66), pp. 91-118, 1998.

Mendes, L. A nobilitação urbana no Bairro Alto: análise de um processo de recomposição socioespacial. Finisterra: Revista Portuguesa de Geografia, 41 (81), pp. 57-82, 2006.

Mendes, L. Gentrificação e políticas de reabilitação urbana em Portugal: uma análise crítica à luz da tese rent gap de Neil Smith. Cadernos Metrópole, 16 (32), pp. 487-511, 2014.

Pavel, F. Transformação urbana de uma área histórica: o Bairro Alto. Reabilitação, identidade e gentrification. Dissertação (Doutoramento), Faculdade de Arquitetura da Universidade de Lisboa (FAUL), Lisboa, 2015.

Pereira, P.; Raposo, O.; Alves, M.; Antunes, M.; Casqueira, F. Rotas Cruzadas: Imigrantes no Coração de Lisboa [Relatório Final], 2004.

Rose, D. Rethinking Gentrification: Beyond the Uneven Development of Marxist Urban Theory. Environment and Planning D: Society and Space, 2 (1), pp. 47-74, 1984.

Smith, N. The new urban frontier: gentrification and the revanchist city. Londres, Nova York: Routledge, 1996.

Smith, N. New Globalism, New Urbanism: Gentrification as Global Urban Strategy. Antipode 34 (3), pp. 427-450, 2002. 
Sobrinho, A. S. São Paulo e a Ideologia Higienista entre os séculos XIX e XX: a utopia da civilidade. Sociologias, Porto Alegre, ano 15, 32, pp. 210-235, 2013.

Zukin, S. The social production of urban cultural heritage: Identity and ecosystem on an Amsterdam shopping street. City, Culture and Society, 3, pp. 281-291, 2012. 



\section{Movimientos sociales, participación y políticas de vivienda}





\title{
Cidades, movimentos sociais e reforma urbana
}

\author{
Uma análise das ações coletivas \\ em Belo Horizonte no século XXI
}

Flávia Duque, Ricardo Carneiro, Thaysa Sonale Almeida Silva, PETTER ISACKSON MAIA Y RODOLFo PINHÓN BECHTLUfFT

\section{Resumo}

A despeito da intensidade do processo de urbanização brasileiro, especialmente na segunda metade do século XX, a questão urbana em seu viés regulatório e redistributivo não chegou a integrar de forma efetiva a agenda governamental no período, propiciando a acumulação urbana, sem garantir o acesso aos bens e serviços urbanos para a maior parte da população. Em decorrência, o quadro socioespacial caracteriza-se pela periferização e metropolização; pela magnitude da ocupação informal, por desigualdades socioespaciais e processos de exclusão. Esses problemas constituem bases de reivindicações e de construção das propostas de reforma urbana por movimentos de moradia e suas articulações como o Movimento/Fórum Nacional de Reforma Urbana. Tais atores coletivos lograram incidir no texto da Constituição Federal de 1988, no Estatuto da Cidade, na legislação relativa à habitação de interesse social e outros marcos normativos da política nacional, afetando também processos locais. A plataforma de reforma urbana assentouse em três pilares: direito à moradia e à cidade, função social da propriedade, e democratização do planejamento 
e da gestão urbanos. O trabalho analisa os movimentos sociais que têm atuado no campo da reforma urbana em Belo Horizonte nas duas últimas décadas, suas plataformas e formas de ação coletiva. Busca-se identificar e analisar como esses atores coletivos têm tematizado a cidade, reatualizado, ressignificado e alargado a agenda de reforma urbana. Os movimentos sociais e associações desde o século anterior influenciaram as políticas locais por meio de mobilizações e de formas de participação institucionalizadas que se retraíram nos últimos governos. No contexto atual, além das manifestações conectadas à política nacional (que não serão abordadas), emergiram novos atores coletivos, multiplicaram-se e pluralizaram-se as formas de ação coletiva contra a mercantilização da cidade e pela apropriação do espaço público. $\mathrm{O}$ artigo analisa os movimentos sociais de moradia e os que atuam na organização de novas ocupações urbanas informais que abrigam cerca de 12.000 famílias; e movimentos que retematizam a cidade e o direito à cidade. $\mathrm{O}$ trabalho integra uma pesquisa em desenvolvimento.

\section{Palavras-chave}

Movimentos sociais; direito à cidade; reforma urbana.

\section{Introdução}

Nas últimas décadas tem-se apontado a ampliação das formas participação social, mediante a expansão e a pluralização dos repertórios e pautas de ação coletiva (Warren, 2002, p.678).

No contexto brasileiro de redemocratização nos 1980, ganharam evidência atores coletivos que se (re)organizaram com pautas endereçadas à democratização, à inclusão social e alargamento dos direitos, dentre os quais o Movimento 
Nacional de Reforma Urbana (MNRU) ${ }^{1}$, que constituiu uma ampla articulação de atores coletivos e logrou influenciar a Constituição Federal e o Estatuto da Cidade - lei federal que regulamenta a política urbana. Nas décadas seguintes, ao lado das formas de organização e mobilização na sociedade civil, amplia-se a infraestrutura de participação institucionalizada, mediante a criação de um número expressivo de instituições participativas no país (conselhos, conferências, orçamentos participativos, dentre outros).

Contudo, em 2013, novos atores e formas de ação coletiva apresentaram-se no ambiente brasileiro, demarcando ciclos de mobilizações. A partir do Movimento Passe Livre, inicialmente em São Paulo, e do Movimento de Atingidos pela Copa, em diversas cidades, expandem-se as manifestações e protestos com pautas difusas, com o protagonismo de atores heterogêneos e em sua maioria não organizados. ${ }^{2}$ Em 2014, tem-se um novo ciclo de mobilizações polarizado, associado às eleições ocorridas no ano, e que se estende em 2015. No período, ocorre também um repertório de movimentos de resistência desde 2015, como as ocupações de escolas e universidades públicas. Em paralelo, tem-se uma crise político institucional que culmina no golpe parlamentar e engendra novas manifestações e repressões aos protestos e manifestações. ${ }^{3}$

Em tais contextos, emergiram novos atores coletivos e multiplicaram-se as formas de ação coletiva. No âmbito local de diversas cidades brasileiras, ao lado de ações coletivas e protestos conectados com a política nacional, destacaram-se atores e ações coletivas na defesa do direito à cidade e contra a sua mercantilização e pela apropriação de espaços públicos, como no caso de Belo Horizonte.

1 O MNRU se reconfigurou nos anos 1990 como Fórum Nacional de Reforma Urbana, articulando movimentos de moradia e outros atores coletivos neste campo. Ver Brasil (2011) e Avritzer (2010).

2 Sobre as manifestações de 2013 e subsequentes, ver Romão (2013), Tatagiba (2014), Silva (2015), Avritzer (2016), e Cafrune (2016).

3 Ver Avritzer (2016). 
Cabe notar que os movimentos sociais não constituem novidade na cidade, que apresenta um tecido movimentalista significativo desde os anos 1960, que incluía os chamados movimentos sociais urbanos e associações de bairros e temáticas. No contexto de redemocratização, destacam-se atores coletivos organizados em torno do mote da moradia, da reforma urbana e da proteção ao meio ambiente, ao lado de movimentos e mobilizações no campo das políticas sociais, de gênero e diversidade. A partir de 1993, no governo da Frente BH-Popular ${ }^{4}$, foi implementada uma arquitetura participativa ampla e plural na cidade, com instituições participativas como conselhos, orçamento participativo e conferências de políticas. Contudo, nos governos recentes $^{5}$ a dimensão participativa foi esvaziada e, em paralelo, ampliaram-se as ações coletivas e reconfigurou-se o tecido movimentalista.

Diante deste quadro, focalizam-se os movimentos sociais recentes que retematizam a cidade com suas pautas que podem ser associadas à perspectiva de reforma urbana, referida à pauta da função social da propriedade, da gestão democrática das cidades e do direito à moradia e à cidade. Este último pode ser entendido de forma ampla, nos termos de Harvey (2014, p.28), como as possibilidades emancipatórias, de mudança e reinvenção da cidade.

O trabalho insere-se em uma pesquisa exploratória em desenvolvimento ${ }^{6}$ e aborda os principais movimentos sociais que têm atuado no campo da reforma urbana em Belo Horizonte, com o corte temporal nas duas últimas décadas. Além de apresentar um panorama desses movimentos, o artigo tem por objetivo analisar como esses atores coletivos

4 Encabeçada pelo Partido dos Trabalhadores (PT), com o Prefeito Patrus Ananias.

5 Duas gestões do Prefeito Márcio Lacerda, do Partido Socialista Brasileiro (PSB), no período 2009-2016.

6 "Participação social, movimentos sociais e ação coletiva em Belo Horizonte", voltada para a análise dos movimentos sociais, suas formas de ação coletiva e repertórios de interação com o poder público. 
têm retematizado a cidade e reatualizado a agenda societária de reforma urbana e quais os seus repertórios de ação coletiva. Especificamente, serão focalizados movimentos sociais associados às novas ocupações urbanas informais e os demais atores coletivos com plataformas associadas à reforma urbana e ao direito à cidade.

\section{Marco teórico/marco conceitual}

Em esforço de articulação de diferentes perspectivas, Della Porta e Dianni (1999, p.165) caracterizam os movimentos sociais como redes de interações informais entre uma pluralidade de indivíduos, grupos e/ou organizações engajadas em confronto político ou baseadas em elementos culturais e identidades coletivas compartilhadas. Também de forma mais geral, em sua abordagem de movimentos sociais, Cohen e Arato (1992) destacam sua natureza coletiva e primariamente informal, constituindo a expressão de conflitos e apontando para possibilidades de mudança social. Mais além, os autores postulam lógicas de ação coletiva complementares e não excludentes para os movimentos sociais contemporâneos, envolvendo tanto a construção de identidades coletivas quanto a orientação estratégica; tanto as formas de ação contenciosas, quanto formas de ação mais institucionalizadas endereçadas a afetar o sistema políticoinstitucional (Brasil et al., 2017). ${ }^{7}$

Dados os limites desse artigo, apenas destacamos no campo dos movimentos sociais contribuições que se mostram relevantes como chave analítica. Uma primeira chave

7 A partir do contexto brasileiro das últimas décadas, que se marca pela ampliação de instituições participativas, essa discussão tem comparecido sob vários prismas nos debates e desenvolvimentos teóricos e analíticos recentes no país, que colocam em foco as formas de ação mais institucionalizadas desses atores e sua relação com o Estado. (Dowbor, 2014; Abers; Tatagiba et al., 2012; Silva, 2015; Carlos, 2015). 
refere-se à noção de repertório de ação coletiva que Tilly (1995, p.26) reconceitua como "conjunto limitado de rotinas que são aprendidas, compartilhadas e postas em ação por meio de um processo relativamente deliberado de escolha".

Um outro ponto importante refere-se à construção de significados partilhados que Melucci (1996) trata como um amalgama para ação coletiva e para o próprio processo de construção de identidades coletivas. Adiante, McAdam, McCarthy e Zald (1999, p. 3-23) reconhecem a importância das dimensões ideacionais e cognitivas da ação, incorporando fundamentos culturais na noção de frame ou enquadramento interpretativo também como uma das bases para a ação coletiva.

Nessa linha, coloca-se a questão da construção do significado de reforma urbana e do direito à cidade desde a perspectiva dos movimentos sociais, que se constituiu como uma base em reconstrução permanente para as ações coletivas no contexto brasileiro.

A ideia de reforma urbana remonta à década de 1960, no bojo das discussões sobre habitação de interesse social e é objeto de reconstruções no período autoritário, por parte dos movimentos sociais e outros atores sociais. No contexto de redemocratização, esses atores se articulam no MNRU e apresentam uma emenda popular à Assembleia Nacional Constituinte, que resulta em afetar o texto da Constituição Federal de 1988. A agenda de reforma urbana condensa-se, então, em três pontos: direito à moradia e à cidade; função social da propriedade; e gestão democrática das cidades. A própria noção de direito à cidade remete, nesse contexto, às demandas de inclusão socioespacial decorrentes dos processos de exclusão, das desigualdades e dos déficits de inclusividade das cidades brasileiras. No decorrer das décadas seguintes, mediante a atuação dos movimentos e atores coletivos, a agenda de reforma urbana

8 Ver a revisão do conceito que foi efetuada por Alonso (2012). 
se concretiza em alguma medida na legislação (no Estatuto da Cidade) e, em alguns casos, em práticas no contexto de administrações democrático populares. Mais além, essa agenda se alarga, mantendo os núcleos referenciados, inclusive a noção de direito à cidade aqui mobilizada. (Brasil, 2011; Avritzer, 2010).

A Carta Mundial pelo Direito à Cidade, redigida por movimentos sociais brasileiros, latino-americanos e de diversos países no bojo do Fórum Social Mundial (FSM) sustenta que "a luta pelo direito à cidade tem como objetivo tornar o valor de uso predominante sobre o valor de troca, construir o direito coletivo e da importância da política." (FSM, 2006), apontando para a primazia do valor de uso na linha das reflexões de Lefebvre (2011). Como afirma Rodrigues (2007), "a utopia da cidade como direito quer o usufruto coletivo da e na cidade. $\mathrm{O}$ 'valor', para os seus defensores, é o valor de uso e pressupõe o acesso universal na apropriação e usufruto da cidade."

Nos termos da citada Carta Mundial, direito à cidade "implica enfatizar uma nova maneira de promoção, respeito, defesa, realização dos direitos civis, políticos, econômicos, sociais, culturais e ambientais garantidos nos instrumentos internacionais de direitos humanos", e ainda, "a luta pelo direito à cidade tem como objetivo tornar o valor de uso predominante sobre o valor de troca, construir o direito coletivo e da importância da política”. (FSM, 2006).

De acordo com Harvey (2014, p. 28), a ideia de direito à cidade remete às possibilidades emancipatórias, de mudança e reinvenção da cidade e depende, assim, do exercício de poder coletivo sobre o processo de urbanização. $\mathrm{O}$ direito à cidade não pode ser concebido como direito individual. Conforme Harvey (2013, p. 33), demanda um esforço coletivo e formação de direitos coletivos a partir de solidariedades sociais, apontando para a "criação de espaços urbanos comuns, de uma esfera pública de participação democrática, 
exige desfazer a enorme onda privatizante que tem servido de mantra ao neoliberalismo destrutivo dos últimos anos direito de fazer uma cidade diferente”.

\section{Metodologia}

$\mathrm{O}$ artigo analisa os movimentos sociais que retematizam a cidade e o direito à cidade, partindo de uma breve revisão de literatura no campo dos movimentos sociais e ações coletivas, na qual se destacou e as bases cognitivas para a ação coletiva e a noção de repertório. Outra linha de revisão examina a perspectiva de reforma urbana e direito à cidade, tendo em vista situar e enquadrar os movimentos sociais focalizados.

$\mathrm{O}$ artigo apresenta um mapeamento inicial dos principais movimentos sociais na Belo Horizonte do século XXI, identificando os atores coletivos, suas pautas/agendas e repertórios de ação. A pesquisa recorreu a levantamentos documentais basicamente a partir de sítios da internet (web) de periódicos e dos próprios movimentos, bem como das páginas desses atores coletivos nas redes sociais. No decorrer de 2016, foram empregadas técnicas de observação direta e entrevistas semiestruturadas com lideranças e/ ou informantes-chave participantes dos movimentos.

\section{Análise e discussão de dados}

Para fins analíticos distinguem-se os movimentos sociais associados às ocupações urbanas recentes dos demais movimentos que retematizam a cidade sob o prisma da reforma urbana e do direito à cidade. A análise busca identificar esses movimentos sociais, resultando em um panorama dos atores coletivos, abordando os motes e repertórios de ação coletiva. 


\section{a) Movimentos sociais e as novas ocupações urbanas}

As ocupações informais constituem um fenômeno muito expressivo em Belo Horizonte e na própria Região Metropolitana (RMBH) nas duas últimas décadas. A estimativa é o envolvimento de 14.269 famílias correspondendo aproximadamente a 55 mil pessoas nas 24 ocupações na RMBH (Libânio et al., 2016, p.11), das quais 13 se encontram em Belo Horizonte, como mostrado no Quadro 1, excetuando-se a recente Ocupação Carolina, em um prédio da Secretaria Estadual de Saúde.

Para Nascimento (2016, p. 161) essas ocupações configuram-se como um "movimento livre de criação de uma outra cidade, ainda que em terrenos precários e condições sociopolíticas vulneráveis e até mesmo violentas". Canetierre (2017) reporta a visão das ocupações como uma prática política, com os mutirões organizados sob a lógica da autogestão e da participação social, que permite pensar novas formas de produzir, organizar e viver a cidade. ${ }^{9}$ Para o autor, as ocupações urbanas não são apenas um movimento popular de luta pelo direito de moradia, embora seja o elemento central da sua articulação. Mais que isso, elas indagam as contradições inerentes à apropriação capitalista do espaço urbano, permitindo o surgimento de novas relações democráticas possíveis, contrapondo a heteronomia do capitalismo à autonomia das práticas populares autogestionárias na cidade, a constituição do poder popular ao poder político e econômico do capital e a sociabilidade comunitária ao individualismo.

9 Outra perspectiva seria o entendimento das ocupações como favelas e loteamentos clandestinos como uma forma de exploração do trabalhador uma vez que o item habitação não é considerado no salário dos trabalhadores e estes, por sua vez, teriam que apelar para a autoconstrução de sua própria moradia (Oliveira 2006). 
Como afirma Lelis (2016), as ocupações se configuram como fenômeno político e social de luta pelo direito à cidade e à moradia digna, e caracterizam-se pela organização, mobilização, formação de um quadro de militância e pela construção de um discurso que denuncia a hegemonia do interesse privado em detrimento do interesse coletivo, na medida em que grandes porções de terra aguardam valorização e viabilidade econômica ao mesmo tempo em que muitas famílias são excluídas do direito de habitar a cidade e usufruir de serviços públicos.

Nessa direção, as ocupações constituem "novos territórios insurgentes" nos termos de Mayer (2015) e diferem das favelas (que também constituem ocupações informais), pelo seu caráter de ação coletiva organizada - e até mesmo planejada urbanisticamente - a partir de atores coletivos.

Os principais movimentos sociais envolvidos na organização das ocupações são o Movimento de Luta nos Bairros, Vilas e Favelas (MLB), que atualmente também se organiza no âmbito nacional, e as Brigadas Populares (BP). O MLB, que se liga ao Partido Comunista Revolucionário (PCR), organiza-se em 1999, inicialmente em Belo Horizonte a partir de divergências em um processo de ocupação (Silva, 2012). Para o MLB a prática das ocupações e luta pela moradia é o principal instrumento de luta pela reforma urbana. A prática da ocupação também significa, para o movimento, um processo pedagógico de transformação social: "a ocupação educa o povo para a necessidade de lutar organizado e desenvolve o espírito de trabalho coletivo" (MLB, 2017).

As BP surgiram a partir de um grupo de estudos sobre marxismo de alunos da Faculdade de Direito da Universidade Federal de Minas Gerais (UFMG). Em 2006, parte desse grupo começou a realizar um trabalho social em uma favela, proporcionando um contato 
direto com uma associação de moradores do local que estava se mobilizando para a ocupação de um prédio. O grupo que compõe as BPs atualmente é mais amplo e diverso, expandindo-se pelo estado e articulando-se a nível nacional com outros movimentos. Em 2011, houve um processo de fusão das BPs com outros três coletivos com linha de atuação similar (Brasil et al., 2017).

Além desses dois movimentos que se apresentam de forma expressiva e recorrente nas ocupações, destacamse outros atores envolvidos nas ocupações em foco, como a Comissão Pastoral da Terra (CPT), ligada à Igreja Católica, a Pastoral da Juventude (PJ) e a Frente Terra e Autonomia (FTA), ao lado de associações e fóruns locais. Além da organização Arquitetas sem Fronteiras (AsF), algumas ocupações contaram com assessorias técnicas ligadas à UFMG e à Pontifícia Universidade Católica (PUC).

O Quadro 1 apresenta as ocupações que ocorreram nas duas últimas décadas, permitindo vislumbrar a dimensão do fenômeno e o espectro de atores coletivos envolvidos na mobilização e organização das ocupações. 


\section{Quadro 1 - Ocupações informais organizadas em Belo Horizonte a partir de 2000}

\begin{tabular}{|c|c|c|c|c|c|}
\hline Ocupaçăo & Ano & $\underset{\text { familias }}{\mathrm{N}^{\circ}}$ & $\begin{array}{c}\text { Movimentos } \\
\text { envolvidos }\end{array}$ & Localizaçăo & Obseneçōes \\
\hline $\begin{array}{l}\text { Novo } \\
\text { Lijedo }\end{array}$ & 2002 & 3.500 & $\begin{array}{l}\text { BP } \\
\text { Associaciaio } \\
\text { Cornumitiaria }\end{array}$ & $\begin{array}{l}\text { Belo } \\
\text { Horizonte } \\
\text { (Regio Izidora) }\end{array}$ & 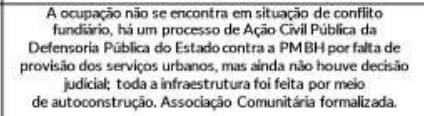 \\
\hline $\begin{array}{l}\text { Camilo } \\
\text { Torres }\end{array}$ & 2008 & 142 & $\begin{array}{l}\text { Fónum de M } \\
\text { oradia do } \\
\text { Barreiro }\end{array}$ & $\begin{array}{l}\text { Belo } \\
\text { Horizonte } \\
\text { (Barreiro) }\end{array}$ & $\begin{array}{c}\text { Há mandado de reintegraçä́o de posse, mas sem confrmaçáo } \\
\text { de propriedade e falta de "operacionalidade" da PM. } \\
\text { A rede de água está sendo implantada pela COPASA } \\
\text { desde } 2015\end{array}$ \\
\hline Dandara & 2009 & 1.200 & $\begin{array}{l}\text { CPT } \\
\text { BP }\end{array}$ & $\begin{array}{l}\text { Belo } \\
\text { Horizonte } \\
\text { (Céu Azul) }\end{array}$ & 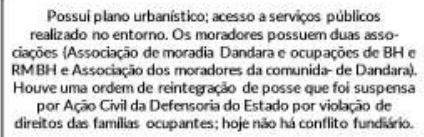 \\
\hline $\begin{array}{l}\text { Irmă } \\
\text { Dorothy }\end{array}$ & 2009 & 223 & $\begin{array}{l}\text { Fórum de M } \\
\text { oradia do } \\
\text { Barreiro }\end{array}$ & $\begin{array}{l}\text { Belo } \\
\text { Horizonte } \\
\text { (Barreiro) }\end{array}$ & $\begin{array}{l}\text { Assistència do Grupo Privés (EA/UFMG) e assessoria } \\
\text { juridica da PUC/Minas, importante no questionamento de uma } \\
\text { ordern de reintegaçio de posse; a situasça juridica é a mesma } \\
\text { da Camilo Torres. A água está sendo implantada } \\
\text { pela COPASA desde } 2015 \text {. }\end{array}$ \\
\hline $\begin{array}{l}\text { Zilah } \\
\text { Spósito/ } \\
\text { Helena } \\
\text { Greco }\end{array}$ & 2011 & 130 & $\begin{array}{l}\text { MLPM } \\
\text { BP CPT }\end{array}$ & $\begin{array}{c}\text { Belo } \\
\text { Horizonte } \\
\text { (bairro Ziah Sp } \\
\text { ósito) }\end{array}$ & $\begin{array}{l}\text { No inicio houve uma tentativa de remoçào forçada e } \\
\text { violenta pela guarda municipal com anuência da PMBH, mas } \\
\text { foi superada pela acáo dos movimentos sociais e pela açāo } \\
\text { judicial do Ministério Público estadual. }\end{array}$ \\
\hline $\begin{array}{l}\text { Vila Pomar } \\
\text { do Cafezal }\end{array}$ & 2012 & 120 & AsF / BP & $\begin{array}{l}\text { Belo } \\
\text { Horizonte, } \\
\text { bairro } \\
\text { Serra, Centro- } \\
\text { Sul } \\
\text { (Agjomerado } \\
\text { da Serra) }\end{array}$ & $\begin{array}{l}\text { Surgimento em maio de 2012; possui } 5 \text { anos (em 2017); } \\
\text { situada em terreno acidentado, em } 2013 \text { a URBEL e Defesa } \\
\text { CWil tentaram remover as familias alegando risco de } \\
\text { desfizamento e instabilidade goológica em laudo; com apoio } \\
\text { dos Arquitetos Sem Fronteira, os moradores questionaram o } \\
\text { laudo da PMBH, mostrando que năo há instabilidade do solo, } \\
\text { mas sim, pontos instáveis localizados, o que foí minimizado } \\
\text { com a iniclativa de plantio de árvores frutiferas (pomar de } \\
\text { desfrute coletivo), as ordens de remoçäo foram suspensas em } \\
\text { virtude de outros laudos técnicos; a comunidade é servida peba } \\
\text { rede de serviços do Agjomerado da Serra. }\end{array}$ \\
\hline $\begin{array}{l}\text { Novo } \\
\text { Paraiso }\end{array}$ & 2012 & 350 & $\mathrm{BP} / \mathrm{CPT}$ & $\begin{array}{l}\text { Belo } \\
\text { Horizonte } \\
\text { (bairro } \\
\text { Palmeiras) }\end{array}$ & 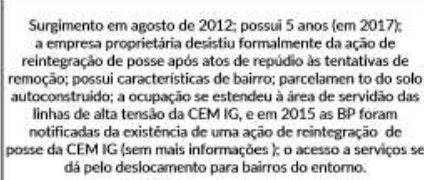 \\
\hline
\end{tabular}




\begin{tabular}{|c|c|c|c|c|c|}
\hline Eliana Silva & 2012 & 350 & $M \perp B$ & $\begin{array}{c}\text { Belo Horizon- } \\
\text { te (Barreiro) }\end{array}$ & 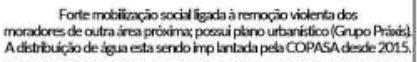 \\
\hline Rosa Leão & 2013 & 1.500 & M LB CPT BP & $\begin{array}{l}\text { Belo Horizonte } \\
\text { (bairro } \\
\text { Zilah Spósito } \\
\text {-|zidora) }\end{array}$ & 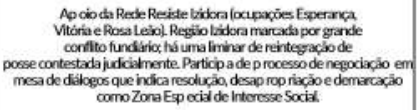 \\
\hline $\begin{array}{l}\text { Nelson } \\
M \text { andela }\end{array}$ & 2013 & 310 & $\begin{array}{l}\text { MLB } \\
\text { CPT }\end{array}$ & $\begin{array}{l}\text { Belo Horizonte } \\
\text { (Barreiro) }\end{array}$ & Mesma sítuaçäo da ocup ą̧̄o Camỉo Torres \\
\hline $\begin{array}{c}\text { Vila } \\
\text { Esp erança }\end{array}$ & 2014 & 70 & FTA & $\begin{array}{l}\text { Belo Horizonte } \\
\text { (Calafate) }\end{array}$ & ? \\
\hline Terra Nossa & 2014 & 235 & Nenhum & $\begin{array}{l}\text { Belo Horizonte } \\
\text { (Taquaril) }\end{array}$ & - \\
\hline Paulo Freire & 2015 & 170 & $M L B$ & $\begin{array}{c}\text { Belo Horizonte } \\
\text { (Barreiro) }\end{array}$ & 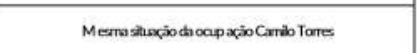 \\
\hline
\end{tabular}

Fonte: Elaboração dos autores a partir de Libânio e Morado (2016).

A Ocupação Dandara constitui o caso mais bemsucedido e emblemático, contando com um plano urbanístico a partir da assessoria técnica de arquitetos do Escritório de Integração da PUC-Minas que definiu, em conjunto com os moradores, diretrizes de uso e ocupação, obedecendo à legislação urbanística vigente. Apesar da condição de informalidade, a ocupação já conseguiu que uma reintegração de posse fosse suspensa e, com um considerável número de delegados para a votação do Orçamento Participativo municipal (2015/2016), aprovou obras de pavimentação das ruas (Libânio et al., 2016, p.33).

Para finalizar esta seção, cabe esclarecer que, além das ocupações que atuam na cidade, há outros movimentos de moradia que também se associam à agenda de reforma urbana construída pelo MNRU e se organizam no âmbito nacional, como a União Estadual por Moradia Popular (UEMP) que atuou na produção autogestionada de moradias no Programa Crédito Solidário, criado no governo Lula. 
Também atua na cidade um grande número de Associações de Bairro que, em parte, se articulam à Confederação de Associações de Moradores (CONAM).

\section{b) Movimentos culturais e ambientais, reforma urbana e direito à cidade}

Em paralelo às ocupações, emergiram novos movimentos e ações coletivas em Belo Horizonte que se associam à chave da reforma urbana e do direito à cidade. Os movimentos, seus participantes, agendas e repertórios de ação estão consolidados no Quadro 2.

O Movimento Tarifa Zero denota problemas de mobilidade e, mais além, aponta para a defesa da ideia do direito à cidade como um direito social. O Salve Santa Teresa destaca-se na perspectiva de preservação do patrimônio cultural do bairro, marcando-se como um movimento de resistência à especulação imobiliária e à lógica de mercantilização da cidade, apontando para demandas de qualidade de vida urbana. Também os movimentos Mata do Planalto e Parque Jardim América, além da perspectiva de preservação ambiental, afirmam-se nesta mesma linha de resistência, enquanto o Fica-Ficus e o SOS Parque das Mangabeiras colocam-se em caráter oposicional às iniciativas do governo municipal, no último caso em oposição a um padrão empreendedorista de gestão. Contudo, o Fica-Ficus também se alinha em sua pauta com os demais movimentos (Praia da Estação, Viaduto Santa Teresa e Muitxs), que, em uma linha cultural, se afirmam na perspectiva de direito à cidade como inclusão que se coloca desde a apropriação e democratização dos espaços públicos, apontando para as potencialidades de tematização da cidade e de radicalização democrática.

Um ponto comum a esses movimentos consiste no uso amplo das redes sociais. Se no caso das ocupações esse recurso se coloca como essencial nos momentos de conflito, permitindo mobilizar apoios, no caso desses movimentos 
as redes são empregadas para manifestações nos momentos críticos, mas também para mobilização de eventos com caráter lúdico, que retomam a cidade como lócus da festa e do encontro, como vislumbrado por Lefebvre (2011).

\section{Quadro 2- Movimentos ambientais e culturais que retematizam a cidade}

\begin{tabular}{|c|c|c|c|c|}
\hline Movimento & $\begin{array}{l}\text { Ano de } \\
\text { emergência }\end{array}$ & $\begin{array}{c}\text { Agenda e } \\
\text { significados } \\
\text { compartilhados }\end{array}$ & Participantes & Repertórios de açăo \\
\hline $\begin{array}{c}\text { Salve Santa } \\
\text { Tereza }\end{array}$ & $\begin{array}{c}1996 \mathrm{e} \\
\text { reconfigura se em } \\
2013\end{array}$ & $\begin{array}{c}\text { Luta contra a especulaçāo } \\
\text { imobilíria e intervençōes } \\
\text { que ameacem o bairro, seu } \\
\text { patrimönio e a qualidade } \\
\text { de vida da p op ulaçäa, } \\
\text { contraposto à } \\
\text { mercantilizaçáo da cidade. }\end{array}$ & $\begin{array}{c}\text { Movimento que reúne mora- } \\
\text { dores do bairro e articula-se a } \\
\text { outros movimentos. Surgiuem } \\
1996 \text { diante da mudança de } \\
\text { legislaçảo e esp eculaçăo } \\
\text { imobiliária. }\end{array}$ & $\begin{array}{l}\text { Manifestaçōes e encontros na } \\
\text { Praça Duque de Cavias; pressăo e } \\
\text { diálogo com o govemo local. } \\
\text { Obteve sucesso cm diversas pautas }\end{array}$ \\
\hline $\begin{array}{l}\text { Satvea Mata } \\
\text { do Planalto }\end{array}$ & 2009 & $\begin{array}{l}\text { Luta contra a especulaçato } \\
\text { imobilisria e pela } \\
\text { preservaçio do } \\
\text { remanescente de mata } \\
\text { atlàntica corhecida como } \\
\text { Mata do Planalto, localaado } \\
\text { no bairro Planalto em BHe } \\
\text { pelo uso do local pela } \\
\text { populaçâo em atividades } \\
\text { que contribuam para a } \\
\text { melhoria da qualidade de } \\
\text { vida. }\end{array}$ & $\begin{array}{c}\text { Composto principalmente por } \\
\text { moradores dos bairros Planalto, } \\
\text { Campo Alegre e Vila Cloris e } \\
\text { ambientalista }\end{array}$ & $\begin{array}{l}\text { O movimento se mobiliza a partir } \\
\text { de carretas, caminhadas, } \\
\text { atividades culturais e apresenta } \\
\text { intense uso das redes sociais e da } \\
\text { midia local p ara mobilização. } \\
\text { Institucionalmente com a } \\
\text { participaçăo em audiéncias } \\
\text { públicas e discussóes com o poder } \\
\text { público e Ministério Pública. }\end{array}$ \\
\hline $\begin{array}{l}\text { "Prala' da } \\
\text { Estaçöo }\end{array}$ & 2010 & 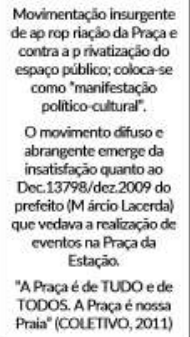 & $\begin{array}{c}\text { A "praia" foi mobilizada por } \\
\text { meio das redes sociais, envol- } \\
\text { vendo particip antes } \\
\text { heterogêneos, principalmente } \\
\text { segmentos de classe média, ao } \\
\text { lado de movimentose } \\
\text { coletivos já atuantes na } \\
\text { cidade. }\end{array}$ & $\begin{array}{l}\text { Os manifestantes ocup am a } \\
\text { praça e se apropriam do } \\
\text { espaço, inclusive se moihando } \\
\text { nas fontes, de onde o mote } \\
\text { "Praia da Estaçáo". Um } \\
\text { Decreto posterior, em } 2011 \\
\text { passa a permit ir eventos na } \\
\text { Praça com autoriz açäo e é } \\
\text { chamado pelos manifestantes } \\
\text { como "Lei da Praça Livre". } \\
\text { Alguns coletivos se } \\
\text { constituiram a p artir dessas } \\
\text { açóes coletivas e fó } \\
\text { constituido também um Bloco } \\
\text { de Camaval cm } 2012 \text {. }\end{array}$ \\
\hline $\begin{array}{l}\text { Parque trdim } \\
\text { América }\end{array}$ & 2011 & 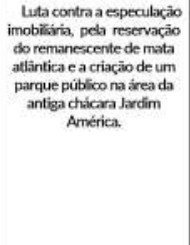 & $\begin{array}{l}\text { O movimento se autodefine } \\
\text { como horizontal, aberto e } \\
\text { apartidário e sem laços insti- } \\
\text { tucionais, sendo comp osto } \\
\text { por moradores da regiäo oeste } \\
\text { de BH, estudantes e } \\
\text { ambientalistas. }\end{array}$ & $\begin{array}{l}\text { O movimento se mobiliza a } \\
\text { partir de reuniöes esporadicas } \\
\text { entre seus participantes, } \\
\text { passeatas, atividades lüdicas, } \\
\text { pelo bloco de camaval "Bloco } \\
\text { do Parque", utilizando as redes } \\
\text { sociais para divulgacāo e. } \\
\text { mobilizaçio para sua causa, } \\
\text { mantendo-se articulado com } \\
\text { outros movimentos ambientais } \\
\text { da cidade. Institucionalmente } \\
\text { participa de audiencias } \\
\text { públicas. }\end{array}$ \\
\hline
\end{tabular}




\begin{tabular}{|c|c|c|c|c|}
\hline Fica Ficus & 2013 & 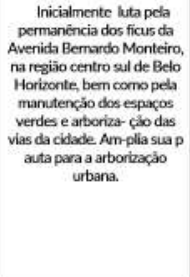 & $\begin{array}{l}\text { O movimento é composto por } \\
\text { ambientalistas, estudantes e } \\
\text { artistas; moradores da cidade } \\
\text { simpatizam-se com a causa. }\end{array}$ & $\begin{array}{l}\text { O movimento mobilizou-se } \\
\text { inicialmente via redes sociais e } \\
\text { mantem essa interaçăo como } \\
\text { chave ao lado de ocupaçōes de } \\
\text { espaços públicos e atividades } \\
\text { lúdicas como piqueniques e } \\
\text { rodas de conversas. } \\
\text { Institucionalmente participa de } \\
\text { audiências públicas no } \\
\text { Iegislativo, om reuniōes e como } \\
\text { governo local e Ministério } \\
\text { Püblica. Obteve éxito com a } \\
\text { suspensalo de cortes dos ficus, } \\
\text { que constituia o mote inicial do } \\
\text { movimento. }\end{array}$ \\
\hline $\begin{array}{c}\text { TarifaZero } \\
\text { BH }\end{array}$ & 2013 & $\begin{array}{l}\text { Autodefinido como um } \\
\text { movimento autónomo } \\
\text { horizontal independente } \\
\text { voltado para a } \\
\text { democratizacilo do } \\
\text { transporte público na } \\
\text { cidade. }\end{array}$ & $\begin{array}{l}\text { M ovimento originário de } \\
\text { mobilizaçăo de estudantes de } \\
\text { diferentes áreas }\end{array}$ & $\begin{array}{l}\text { Diversas manifestaçóes de rua, } \\
\text { colocando um ónibus para } \\
\text { rodar na cidade gratuit amente, } \\
\text { a partir do bloco de carnaval " } \\
\text { Pula Catraca" (fundado pelo } \\
\text { movimento Tarifa Zero BH). O } \\
\text { movimento também participa } \\
\text { de reuniōes de Planejamento } \\
\text { Plurianuais propondo açōes } \\
\text { orçamentárias, do Conselho } \\
\text { Municip al de Mobilidade } \\
\text { Urbana e do Observatório de } \\
\text { Mobilidade Urbana, } \\
\text { conseguindo nessas açōes } \\
\text { impedir por duas vezes o } \\
\text { aumento tarifário em BH. }\end{array}$ \\
\hline $\begin{array}{c}\text { Vixduto Santa } \\
\text { Tereza } \\
\text { Oapado }\end{array}$ & 2014 & $\begin{array}{l}\text { Reivindica a } \\
\text { transparência, respeito e } \\
\text { participacăo popular na obra } \\
\text { de revitalizaçalo do Viaduto } \\
\text { de Santa Tereza, un dos } \\
\text { principais símbolos } \\
\text { arquitetônicos e históricos } \\
\text { da cidade. }\end{array}$ & $\begin{array}{c}\text { Em 08/02 o Viaduto fol } \\
\text { ocupado (artistas, praticantes } \\
\text { de skate e patins) em protesto } \\
\text { a uma cerca pela colocada pela } \\
\text { prefeitura, derrubando as } \\
\text { cercas. A partir dali passaram a } \\
\text { acontecer reunióes periódica } \\
\text { ampliando o público, na } \\
\text { maioria jovem. }\end{array}$ & $\begin{array}{l}\text { Ocupaçáo do viaduto e } \\
\text { retirada das cercas de } \\
\text { isolamento; assembleias } \\
\text { periódicas entre os integrantes } \\
\text { do movimento e reuniōes com } \\
\text { o poder público. Ocorrem } \\
\text { também eventos e } \\
\text { manifestaçōes culturais } \\
\text { diversas sob o viaduto. }\end{array}$ \\
\hline $\begin{array}{l}\text { Muitbe- } \\
\text { Cidadeque } \\
\text { Queremos }\end{array}$ & 2015 & $\begin{array}{l}\text { Movimento transversal } \\
\text { que se define a partir de } 3 \\
\text { eixos: direito à cidade, } \\
\text { radicalizaçio do democracia } \\
\text { e representathidade de } \\
\text { minorias Pauta de dicputar } \\
\text { as eleicües municipais teve } \\
\text { como insp iraçalo as } \\
\text { plataformas munichalistas } \\
\text { na Esparnha (Ahora M adride } \\
\text { Barcelona em Comu). }\end{array}$ & $\begin{array}{l}\text { Agregou p articip antes de } \\
\text { perfil heterogénco quanto à } \\
\text { faixa etária, de renda e } \\
\text { atuacāio profissional. Aglutina } \\
\text { coletivos e articula-se com } \\
\text { diversos movimentos. }\end{array}$ & $\begin{array}{l}\text { A retomada do espaço püblico } \\
\text { mediante a realização de } \\
\text { reuniōs e diversas açōes } \\
\text { coletivas, inclusive de cunho } \\
\text { húdico. O movimento articulou- } \\
\text { se com o Partido Socialismo e } \\
\text { Liberdade (PSOL). } \\
\text { apresentando } 12 \text { candidatos a } \\
\text { vereador nas eleiçóes } \\
\text { municipais. Elegeram } 2 \\
\text { vereadoras, uma das quais foi a } \\
\text { mais vot ada na cidade. }\end{array}$ \\
\hline $\begin{array}{l}\text { SOSParque } \\
\text { das } \\
\text { Mangabeins }\end{array}$ & 2016 & $\begin{array}{l}\text { Luta contra a privatização } \\
\text { do Parque das Mangabeiras } \\
\text { e pela conservaçāo } \\
\text { ambiental da fauna c flora } \\
\text { do parque. }\end{array}$ & $\begin{array}{l}\text { Ambientalistas, } \\
\text { concessionários que trabalham } \\
\text { no parque e moradores (de } \\
\text { dasse média alta) dos bairros } \\
\text { vizinhos. }\end{array}$ & $\begin{array}{l}\text { Reuniōes e debates, atividades } \\
\text { lúdicas como caminhadas, } \\
\text { interlocuçáo com } \\
\text { representante do Legislativo. }\end{array}$ \\
\hline
\end{tabular}

Fonte: Brasil et al. (2017).

O Quadro 2 mostra a diversidade dos movimentos e de repertórios de ação coletiva, seja na linha do ativismo oposicional, seja em ações mais institucionalizadas e diálogos com o poder público. Mostra, também, como os significa- 
dos construídos e compartilhados pelos movimentos e a sua agenda convergem com a perspectiva de reforma urbana atrelada ao direito à cidade em sua acepção mais ampla.

Destaca-se o "Muitxs - Cidade que queremos", não apenas por ter logrado sucesso em sua estratégia de "ocupar" o legislativo municipal com a eleição de duas vereadoras, que em si, mostra- se como uma linha de ação singular e inovadora. A vocação transversal do movimento abarca o direito à cidade de forma ampla, associado às suas pautas de radicalizar a democracia e a representação de minorias. Nesse sentido, conforme um dos manifestos do movimento citado em Brasil et al. (2017, p.20), o Muitxs volta-se para lançar "candidaturas que levem ao protagonismo os sujeitos das lutas sociais, corpos que expressem a diversidade de gênero, raça, orientação sexual e territórios, buscandose a paridade."

\section{Conclusões}

O panorama revelado no artigo permite perceber a multiplicidade e a diversidade de movimentos sociais que se endereçam às pautas vinculadas ao direito à cidade e se apresentam em cena neste século em Belo Horizonte.

A extensão e a ampliação recente do tecido movimentalista suscitam algumas questões. De um lado, pode ser associada, a partir de 2013, em parte ao próprio contexto nacional, marcado por um ciclo de mobilizações. Contudo, em parte pode-se atribuir o florescimento de novas formas de ação coletiva ao contexto local, considerando-se o perfil do governo municipal, no que refere ao relativo esvaziamento das instituições participativas e, ainda, aos déficits de inclusividade socioespacial e à orientação empreendedorista no tratamento da questão urbana. 
Para além dos motes da moradia, da defesa do patrimônio ambiental ou de apropriações culturais, que constituíram motes específicos de ação coletiva, os movimentos em foco construíram significados e pautas mais abrangentes. Nesse sentido, o Muitxs bem vocaliza uma agenda ampla (e convergente com outros movimentos) de direito à cidade, inclusão das minorias e radicalização democrática.

As ocupações urbanas e demais ações coletivas em suas pautas convergem com a agenda de reforma urbana construída pelos atores coletivos no período de redemocratização do país e em suas pautas e práticas reatualizam e ampliam essa plataforma. Caracterizam-se como movimentos sociais voltados para o direito fundamental de habitar a cidade, repensando criticamente as formas de uso e ocupação do espaço urbano, a lógica especulativa que reduz a cidade a uma mercadoria ou, ainda, a gestão nos moldes da cidade-empresa. Na condição de manifestantes ou de ocupantes, mediante novas formas de ação coletiva, os movimentos sociais pressionam por uma institucionalização da diversidade cultural e ressignificação de práticas sociais.

Nos dizeres de Harvey (2006), o direito à cidade surge das ruas e bairros. "Ao produzirmos coletivamente nossas cidades, produzimos coletivamente a nós mesmos. Projetos referentes ao que desejamos que sejam nossas cidades são em consequência projetos referentes a possibilidades humanas, a quem queremos ou, o que talvez seja mais pertinente, a quem não queremos vir a ser." (Harvey, 2006, p.210).

\section{Bibliografia}

Abers, Rebecca. Inventing local democracy: grassroots policies in Brazil. Bolder: Lynne Rienner, 2000. 
Alonso, Angela. Repertório, segundo Charles Tilly: história de um conceito. Sociologia \& antropologia, 2 (3), pp. 21-41, 2012.

Avritzer, Leonardo. O Estatuto da Cidade e a democratização das políticas urbanas no Brasil. Revista Crítica de Ciências Sociais, $\mathrm{N}^{\circ}$ 91, 2010.

Brasil, F.P.D.; Carneiro, R.; Silva, T.S.A.; Bechtlufft, R.P. Movimentos Sociais e Cidade: Uma análise das formas de ação coletiva recente em Belo Horizonte. In: III Encontro Internacional de Participação, Democracia e Políticas Públicas, Vitória, ES, 2017.

Brasil, Flávia P.D. Democracia e participação social: a construção de avanços democratizantes nas políticas urbanas pós-1980. Tese Doutorado, Sociologia, UFMG, Belo Horizonte, 2011.

Brasil, Flavia P.D. Participação-deliberativa, novos atores coletivos e a democratização das políticas urbanas federais pós-80. In $35^{\circ}$ encontro anual da ANPOCS, 2012.

Cafrune, Marcelo Eibs. O direito à cidade no Brasil: construção teórica, reivindicação e exercício de direitos. Revista Interdisciplinar de Direitos Humanos, 4 (1), pp. 185-206, 2016.

Canettieri, Thiago. O debate sobre as ocupações urbanas revisitado: entre o vício (da virtude) e a virtude (do vício), a contradição. Revista e-metropolis, ano $8, \mathrm{~N}^{\circ} 29$, 2017. Disponível em: <http://emetropolis.net/system/ artigos/arquivo_pdfs/000/000/219/original/emetropolis29_art3.pdf?1499539999>.

Carlos, E. Movimentos sociais e sistema político nas teorias dos movimentos sociais. Interseções, vol. 17, $\mathrm{N}^{\circ} 1$, Rio de Janeiro, pp. 15-53, 2015.

Cohen, Jean; Arato, Andrew. Civil society and political theory. Cambridge: Mit Press, 1992.

Della Porta, Donatella; Diani, Mario. Social Movements an Introduction. Blackwell Publishing, 1999. Disponível em: <https://www.hse.ru/data/2012/11/03/1249193172/ Donatella_Della_Porta_Mario_Diani_Social_Mov.pdf >. 
Fórum Social Mundial. Carta Mundial pelo Direito à cidade, 2006. Disponível em: <http://www.polis.org.br/uploads/ 709/709.pdf>.

Dowbor, Monika. Para além de recursos para as mobilizações: organizações de movimentos sociais como ação política. In: $38^{\circ}$ Encontro Anual da ANPOCS. Caxambu, 2014.

Harvey, David. Espaços de esperança. São Paulo: Edições Loyola, 2006.

Harvey, David. O direito à cidade. Lutas sociais, $\mathrm{N}^{\circ}$ 29, 2012.

Disponível em: <https://revistas.pucsp.br/index.php/ ls/article/view/18497/13692>.

Harvey, David. A liberdade da cidade. In: Vainer, Carlos et al. Cidades rebeldes. São Paulo: Boitempo, 2013.

Harvey, David. Cidades Rebeldes: do direito à cidade à revolução urbana. São Paulo: Martins Fontes, 2014.

Lefebvre, Henri. O direito à cidade. São Paulo: Centauro, 2001.

Lelis, Natália. Ocupações urbanas: a poética territorial da política. REBUR Revista Brasileira de Estudos Urbanos e Regionais, vol. 18, № 3, set./dez, 2016.

Libânio, Clarice; Morado, Denise. Ocupações urbanas na região metropolitana de Belo Horizonte. Belo Horizonte: Favela é isso aí, 2016.

Mayer, Joviano G.M. O comum no horizonte da metrópole biopolítica. Dissertação (Mestrado) - Curso de Arquitetura e Urbanismo, UFMG, Belo Horizonte, 2015.

Mcadam, D.; Mccarthy, J. D.; Zald, M. N. Comparative perspectives on social movements: Political opportunities, mobilizing structures, and cultural framings. Cambridge University Press, 1999.

Melucci, Alberto. Challenging codes: collective action in the information age. Cambridge: University press, 1996.

Morado, Denise. Outra lógica da prática. In: Morado, Denise (Org.), Saberes [auto]construídos. Belo Horizonte: Associação Imagem Comunitária, 2016. 
Morado, Denise. As políticas habitacionais e as ocupações urbanas: dissenso na cidade. Cadernos Metrópoles, vol. 18, $\mathrm{N}^{\circ} 35$, pp. 145-164, 2016.

Movimento de Luta nos Bairros, Favelas e Vilas. MLB, essa luta é pra valer, 2017. Disponível em: $<$ https://www.mlbbrasil.org/our_team>. Acesso em: 05/11/2017.

Rodrigues, Arlete M. A cidade como direito. Scripta Nova. Revista Electrónica de Geografía y Ciencias Sociales. Barcelona: Universidad de Barcelona, vol. XI, N 245 (33), 2007. <http://www.ub.es/geocrit/sn/sn-24533.htm>.

Rolnik, Raquel. As vozes das ruas: as revoltas de junho e suas interpretações. In: Carlos Vainer, David Harvey, Ermínia Maricato et al. (Orgs.), Cidades Rebeldes: Passe Livre e as manifestações que tomaram as ruas do Brasil. São Paulo: Boitempo/Carta Maior, 2013.

Rolnik, Raquel. Guerra dos Lugares: A Colonização da Terra e da Moradia na Era Das Finanças. São Paulo: Boitempo, 2015.

Romão, Wagner de Melo. As manifestações de junho e os desafios à participação institucional. Boletim de análise politico-institucional, pp. 11-17, 2013.

Santos, Boaventura de Sousa; Avritzer, Leonardo. Para ampliar o cânone democrático. In: Santos, Boaventura de Sousa (Org.), Democratizar a democracia: os caminhos da democracia participativa. Rio de Janeiro: Civilização Brasileira, pp. 39-83, 2002.

Silva, Cleiton Ferreira da. O movimento de luta nos bairros, vilas e favelas $(M L B)$ e a politica de autogestão: análise de uma experiência no bairro Iputinga. Recife-PE. Dissertação (Mestrado) - Curso de Geografia, UFPB, Recife, 2012.

Silva, Marcelo Kunrath. Movimentos Sociais no Brasil: Institucionalização e Contestação. Trabalho apresentado no III Congreso Latinoamericano y Caribeño de Ciencias Sociales, realizado na FLACSO-Ecuador, Quito, 2015. 
276 - Segregación socio-espacial en las ciudades latinoamericanas

Tatagiba, L.; Paterniani, S. Z.; Trindade, T. A. Ocupar, reivindicar, participar: sobre o repertório de ação do movimento de moradia de São Paulo. Opinião Pública, 18 (2), pp. 399-426, 2012.

Tatagiba, Luciana. 1984, 1992 e 2013: Sobre ciclos de protestos e democracia no Brasil. Política er Sociedade, 13 (28), p. 35, 2014.

Tilly, Charles. Contentious repertoires in Great Britain, 1758-1834. In: Traugott, Mark (org.). Repertoires and cycles of collective action. Durham, NC: Duke University Press, pp. 15-42, 1995.

Warren, Mark. What does participation means today? Political Theory, vol. 30, $\mathrm{N}^{\circ}$ 5, 2002. 


\title{
A influência das cooperativas habitacionais uruguaias nos movimentos socias pró-Moradia no Brasil
}

\author{
Aline MARCondes MigLIOLI
}

\section{Resumo}

O estudo sobre a cidade latino-americana no passado e no presente engloba a discussão sobre a falta de moradias, este problema, que é tão antigo quanto o capitalismo, vem sendo combatido desde o início de nossa urbanização a primeira investida em solucioná-lo foi protagonizada pelo movimento higienista no começo do século XX, seguido pelas políticas de habitação popular a partir dos anos 1930. A semelhança entre o tipo de política usada em todo o continente está relacionada com os pressupostos que as regem e com o padrão de política pensado no centro para a América Latina. Atualmente, é possível identificar a existência de um modelo de intervenção pública no setor habitacional muito semelhante entre os países latino-americanos, cuja configuração está baseada nas orientações do Banco Mundial para o setor e envolve uma política de crédito subsidiado com forte articulação entre o setor público e privado. Enquanto os países se adequam às novas diretrizes dos organismos multinacionais para o setor habitacional, um modelo alternativo resiste: a produção habitacional por cooperativas no Uruguai. Surgido durante os anos 1970 como uma alternativa à política de estímulo à construção habitacional em massa como adotada pelos países vizinhos, o movimento 
cooperativo foi responsável pela produção de moradias sem depender da iniciativa privada e nem sobrecarregar o orçamento nacional.

No entanto, ainda assim há resistência em considerar este tipo de intervenção como uma possibilidade de política pública, por mais que a experiência de países como Nicarágua e Costa Rica na incorporação do modelo cooperativista tenha sido exitosa. Frente a esta perspectiva, colocase o caso brasileiro, cujas políticas habitacionais estiveram sempre orientadas pelas diretrizes internacionais e direcionadas para atender aos interesses do setor da construção civil: seja durante a produção em larga escala estimulada pelo Banco Nacional de Habitação, como pelo Programa Minha Casa, Minha Vida, ambos, no entanto, insuficientes para resolver o problema da falta de moradias. Marginalmente à iniciativa pública, surgiram no país iniciativas locais baseadas no modelo de mutirão e de produção por cooperativa como forma de atuação dos movimentos sociais pró-moradia. Partindo desta afirmação, define-se o objetivo deste trabalho como o de identificar e avaliar a contribuição da experiência uruguaia na configuração dos movimentos brasileiros de cooperativismo habitacional. $\mathrm{O}$ método que orientará a pesquisa é o de recuperação histórica dos intercâmbios acadêmicos e políticos entre os dois países, uma vez que é reconhecida a relevância da experiência uruguaia na formação e atuação do Laboratório Habitacional da Universidade de São Paulo, no Movimento Sem Terra no Rio Grande do Sul entre outros movimentos pró-moradia. Espera-se contribuir com esta pesquisa para o debate em torno das alternativas para resolução do problema habitacional.

\section{Palavras chave}

Cooperativas; Moradia popular; altermundialização. 


\section{Introdução}

O programa habitacional Minha Casa Minha Vida - Entidades é um programa que atualmente atende por meio de cooperativas habitacionais, associações, movimentos sociais ou demais entidades privadas, famílias sem fins lucrativos com renda de até $\$ 1800$ reais (a partir de 2017) que corresponde a aproximadamente U\$\$560 e interessadas na obtenção de uma moradia. Apesar de pertencer a uma política estatal e de integrar-se a um programa habitacional que mais amplamente pretende estimular o setor da construção civil apoiando-se em um problema habitacional, a inclusão de uma modalidade de política que permite a autonomia dos sujeitos para exercerem o papel de agentes é inédita no cenário brasileiro e é reflexo de uma luta muito mais antiga.

A narrativa de luta para que um programa de autogestão fosse incorporado em uma política de âmbito nacional foi extensa e envolveu a participação dos movimentos de luta pela moradia e sua articulação com diversos outros agentes no contexto nacional e internacional, como por exemplo a Pastoral da Terra, o movimento cooperativo internacional, a Fundação de Cooperativas Autogestionárias Uruguaia, o movimento dos Sem Terra e etc. Não podemos acusar a academia de falta de interesse pelo movimento por moradia e sua grande vitória em incluir a questão da autogestão da agenda política nacional, mesmo que ainda muito restrito a este segmento. Tampouco temos como objetivo neste trabalho relembrar os processos históricos e transformações que nos últimos 20 anos a União Nacional por moradia passou para consolidar-se como um movimento pautado na autogestão e na demanda pelo direito à moradia e à cidade. Nossa proposta ao longo deste trabalho é relembrar a importância que a aproximação do movimento com as cooperativas uruguaias exerceu na redefinição das principais pautas propostas pelo movimento por moradia, introduzindo pela primeira vez a autogestão como a única forma de emancipação pela política habitacional. 
Defendemos aqui que o contato com a experiência uruguaia foi importante não só pelo modelo de execução e pela inspiração técnica, mas principalmente como uma forma de aprendizado e integração dos movimentos por moradia nacional com seus correspondentes em nível internacional. Essa transformação se faz importante por dois motivos principais, o primeiro diz respeito ao dilema em que se encontrava o movimento por moradia que, formado a partir da população urbana que se viu excluída do programa habitacional anterior durante o período militar, e sem nenhuma perspectiva a ser inserida no mercado privado, concebia que seu acesso a uma moradia não seria possível através do mercado, como também não seria através do Estado, pois seus programas habitacionais produzem um modelo de habitação que não atende às necessidades habitacionais em termos sociais, econômicos e urbanas. Em segundo lugar esta experiência foi importante pois permitiu a validação de que em termos de política habitacional um altermundismo é possível, para além da política habitacional neoliberal propagada pelas agências multilaterais.

A construção deste argumento requer que duas tarefas sejam executadas: primeiro, precisamos compreender brevemente como se organizaram as cooperativas habitacionais uruguaias em seu contexto histórico único e como elas se tornaram um "modelo para exportação" porque estão fundamentadas em um elemento central para os excluídos do mercado habitacional: a lógica do comum. Pretende-se com isso desvincular também o avanço deste tipo de organização da ideia mais fundamental de cooperativa, baseada nas cooperações iugoslavas, alternativas ao socialismo de Estado. O que se pretende é apresentar as cooperativas como formas de cooperação popular, democráticas e participativas. A segunda tarefa que nos propomos é recontar a história do movimento por moradia do Brasil com ênfase nos aprendizados e trocas realizados com o movimento uruguaio e avaliar a transformação de sua forma de atuação após este encontro. Para executar ambas tarefas 
dedicaremos a cada uma, uma subseção e ao final apresentaremos uma conclusão onde voltaremos a debater as possibilidades de construção de um altermundismo.

\section{As Cooperativas Habitacionais de Ajuda-Mútua no Uruguai}

A história do movimento de Cooperativas Habitacionais surgiu a partir de três experiências piloto durante a década de 1960: a Isla Mela, de assalariados rurais, a Fray Bentos, com empregados públicos municipais e a Salton, com empregados ferroviários (Ghilardi, 2017), três iniciativas que buscavam uma forma de fazer frente à falta de políticas habitacionais principalmente em um período de depressão econômica. A repercussão das experiências organizadas pelo movimento cooperativista foi suficiente para que na Lei 13.728, a Ley de Vivienda, que dispunha sobre as políticas habitacionais fosse incluída a provisão habitacional através de cooperativas autogestionárias, onde se estabeleceram as diretrizes para a organização do sistema, os mecanismos de constituição jurídica e estatutária das cooperativas, as modalidades construtivas e de propriedade, a diferenciação entre as unidades cooperativas e as cooperativas matrizes, assim como a regulamentação dos Institutos de Assistência Técnica (IATs). No processo de consolidação das Cooperativas por Ajuda Mútua formou-se a Federação Uruguaia de Cooperativas de Habitação por Ajuda Mútua, a FUCVAM, que centralizou a representatividade e algumas tarefas práticas, permitindo o barateamento da produção e inclusive a produção de alguns insumos.

O papel da FUCVAM como representação das Cooperativas se fez sentir especialmente durante o período da ditadura militar. Logo após o golpe de estado, ocorrido em 1973, o governo militar encerrou a concessão de novos empréstimos, autorizando somente a construção dos 
projetos já aprovados. A prioridade do governo era atender a demanda habitacional a partir da iniciativa privada e, por isso, ele adotou diversas medidas que pretendiam descaracterizar e desarticular as cooperativas por ajuda mútua, como por exemplo, a exigência de uma poupança prévia e o aumento da taxa de juros dos empréstimos (Ghilardi, 1980). O confronto mais direto deu-se no começo dos anos 1980, quando as cooperativas já formavam uma espécie de ilhas de resistência ao regime militar, a partir do anúncio da intenção do governo em transformar o sistema de cooperativas em um sistema de oferta de unidades habitacionais básicas $^{1}$ e de exterminar a propriedade coletiva. A FUCVAM, vislumbrando os impactos negativos que estas medidas representariam, bloqueou o depósito de pagamento das mensalidades ao Banco Hipotecário e coletou milhares de assinaturas a um referendo popular contra a adoção destas medidas. O Governo acatou as demandas da federação e nos anos posteriores ela foi convocada para a Concertación Nacional Programática, com objetivo de contribuir ao debate sobre o retorno democrático.

Eliminada esta ameaça e com a abertura democrática, não se extinguiu, no entanto, a necessidade de resistência durante as décadas seguintes. A principal fonte de instabilidade às cooperativas diz respeito à pressão pela adoção de políticas habitacionais neoliberais pautadas na oferta de unidades básicas e crédito subsidiado. Durante o período do governo Colorado esta pauta esteve mais evidente e para combatê-la a FUCVAM passou a adotar três outras frentes de luta. A luta pela terra se fez através de ocupações diretas, pois o governo militar havia extinguido a disponibilização de sua carteira terras estatais e este mecanismo só voltou a existir com o governo da Frente Amplia. A

1 O sistema de unidades básicas é uma forma de política habitacional utilizada em outros países da América Latina, que consiste no subsídio do Estado a uma unidade habitacional composta de elementos simples, cozinha, banheiro e um quarto geralmente, com a possibilidade de expansão de outros cômodos com o tempo. 
FUCVAM se articulou também à luta pela reconfiguração no mundo de trabalho, marcado pela flexibilidade e baixos rendimentos resultado das reformas neoliberais, ao buscar integrar às cooperativas os trabalhadores de baixa renda; ela também passou a atuar na reabilitação da área central de Montevidéu. Com a Frente Amplia no governo foram realizadas algumas alterações no sentido de oferecer mais respaldo a abrangência às Cooperativas Autogestionárias, como por exemplo, a redução dos rendimentos mínimos, o subsídio diferenciado por renda e o abandono das políticas de unidades básicas.

Após quase cinquenta anos de experiência em cooperativas habitacionais por ajuda mútua, é possível elencar alguns elementos que fizeram com que este modelo de produção representasse muito mais do que um modelo de construção habitacional. Nahoum (2013) atribuí três pilares desta experiência: a propriedade organizada em torno das cooperativas; o sistema de ajuda mútua, que promove um trabalho coletivo e de aprendizagem; e a autogestão, que faz com que a construção da moradia se torne um ambiente de aprendizagem e capacitação, desvinculando-se da exploração vinculada à ajuda mútua. Para além das conquistas internas, a implementação deste modelo em outros países da América Latina (El Salvador, Honduras, Nicarágua, Paraguai, Bolívia e Guatemala) possibilitada pela associação com o We Effect ${ }^{2}$, demonstrou que este é um modelo viável para a América Latina, pois permite que se crie espaços de difusão do conhecimento, de capacitação, de aprendizado, de construção de conhecimento, que faz com que o modelo se adeque as especificidades locais. Ao mesmo tempo, coloca os trabalhadores urbanos e rurais em contato com a realidade latino-americana, constituindo-se uma "globalização a partir de baixo", onde as trocas e as experiências são fundamentais como forma de resistência ao neoliberalismo.

2 Associação entre as cooperativas uruguaias e o Centro Cooperativo Sueco. 


\section{Os movimentos por moradia e a autogestão no Brasil}

O movimento por moradia no Brasil configura-se como um movimento social antigo, presente desde os primeiros estágios da urbanização brasileira, como, por exemplo, a Liga de Inquilinos, nos anos 40, das Sociedades Amigos do Bairro em 1945, dos Movimentos Populares Urbanos durante os anos 70 etc. Todas estas organizações, apesar de coincidirem as pautas na falta de habitação adequada, divergiram no âmbito de suas demandas específicas, que variaram entre a maior proteção jurídica do inquilino, o acesso ao mercado de habitação, melhor acesso ao crédito, direito universal à moradia, direito à cidade etc. ora exigindo mais aporte por parte do Estado, ora invocando intervenções mistas com inclusão da ação privada. A descontinuidade entre as demandas e a repressão violenta ao movimento por moradia nos impede de, neste trabalho, traçar a arqueologia da evolução deste movimento, nos compete, portanto, traçar o panorama sob o qual surgiu o movimento por moradia nos anos 1980, para o qual é preciso compreender o contexto histórico das políticas habitacionais que o precederam.

A política habitacional brasileira esteve sempre pautada em dois pressupostos: o sujeito beneficiado pela política haveria de ser o trabalhador que contribuísse produtivamente para a economia, e por isso, as políticas habitacionais estiveram sempre ligadas com os fundos de poupança do trabalhador; e, a responsabilidade pela provisão de moradias sempre foi do Estado, associado à iniciativa privada. A primeira política habitacional surgiu nos anos 1930, no início da industrialização brasileira, pela necessidade de garantir as formas de reprodução do trabalhador neste momento crucial de implementação da indústria nacional, assim as contribuições aos Institutos de Aposentadoria e Pensão puderam ser utilizadas para a produção de habitações sociais. No entanto, é só no momento seguinte em que de fato se pode considerar que houve uma política habitaci- 
onal nacional, com a implementação do Banco Nacional de Habitação e das COHABs. Esta iniciativa do governo militar buscava não só angariar popularidade, como estimular o setor da construção civil e estimular no trabalhador brasileiro o sonho da Casa Própria, que era realizado a partir dos empréstimos subsidiados pelo governo para a compra de unidades habitacionais produzidas por ele. $\mathrm{O}$ resultado de uma política que se propunha popular foi, no entanto, a apropriação dos subsídios pela classe média devido à concentração de renda e desequilíbrio entre o valor das parcelas e a taxa de inflação; a produção habitacional popular de baixíssima qualidade; um processo especulativo desencadeado pelos grandes bolsões vazios entre o limite urbano e as construções do programa, o que revelou o interesse velado dos proprietários de terra associados ao governo. Não bastasse as críticas ao programa e a associação direta entre o BNH e a corrupção no governo, os anos seguintes ao desmonte desta política foram marcados pela crise da dívida e pela introdução de políticas neoliberais de cunho privatizador, o que em um cenário de abandono das políticas sociais, depressão econômica e desemprego resultou em um aumento expressivo da pobreza.

O reflexo do aumento da pobreza no contexto urbano é medido pela elevação das taxas de ocupação das favelas brasileiras, pois a ocupação informal torna-se a única forma de acesso à moradia. $\mathrm{O}$ aumento da violência e das tensões sociais presentes no contexto de elevação da desigualdade de renda reverberaram no acirramento dos discursos de criminalização dos ocupantes e é a partir deste contexto que no começo dos anos 1980 volta-se a organizar os movimentos sociais em defesa da legitimação desta forma de ocupação urbana e em defesa de democratização política e da participação popular, como por exemplo, o Movimento em Defesa da Favela (MDF). Neste momento aproxima- se das favelas em São Paulo, as Pastorais Sociais da Arquidiocese de São Paulo que, na tarefa de cadastrar os moradores das favelas locais, constata a existência de mais de 20.000 
famílias vivendo em situação precária. A conscientização sobre a magnitude das ocupações informais e a organização social em torno delas somada à possibilidade de apresentação de propostas de emendas populares à Constituinte, criam um ambiente para o debate sobre a Reforma Urbana e é através dele que se formam os movimentos de luta por moradia, dos quais destacamos a União Nacional por Moradia Popular (UNMP) a partir da articulação de outros grupos em torno da União dos Movimentos por Moradia da Grande São Paulo no debate sobre a proposta da Ementa Popular de Reforma Urbana para a Constituição de 1988; e no Movimento Nacional de Luta por Moradias (MNLM), com tradição à ocupação de terras para a moradia popular, entre outros (Ferreira, 2012).

O contato com as cooperativas uruguaias se deu através da aproximação da UNMP ao modelo de cooperativas uruguaias proporcionado pelas assessorias técnicas. A percepção de que se fazia necessário uma forma de produção habitacional de qualidade aprofundou o contato entre os dois países, tornando-se um divisor de águas na forma de atuação do movimento social.

No caso de São Paulo, há que se destacar, ainda, a influência exercida pelo cooperativismo uruguaio (baseado nos princípios da autogestão, ajuda mútua e solidariedade), experiência esta trazida pelas assessorias técnicas dos projetos. A influência das experiências uruguaias, baseadas nas cooperativas habitacionais ligadas aos sindicatos, ainda se faz presente até os dias de hoje, promovendo-se visitas e seminários de intercâmbio entre integrantes dos movimentos de moradia brasileiros e do movimento cooperativista uruguaio (Paz, 1996).

A importância da aproximação com a experiência uruguaia se encontra em dois pontos principais: o distanciamento das demandas antigas de provisão habitacional a partir do Estado, agente que deixou de ser considerado capaz de resolver o problema habitacional como resultado do fracasso das políticas anteriores, como também da 
municipalização da gestão da política habitacional; distinção entre o modelo de produção cooperativo com o modelo de mutirão ${ }^{3}$ que foi apropriado por alguns governantes e passou a servir como forma de contornar o problema da falta de recursos do Estado utilizando-se da exploração do trabalhador. A forma de trabalhar a partir de assessoramento técnico, autogestão e cooperação permitiram uma organização e unificação que ampliaram o espaço político do movimento por moradia.

A partir da eleição do presidente Lula, a UNMP reivindicou seu espaço político, que resultou no Programa de Crédito Solidário, que financiava a aquisição de terrenos e construção de moradias populares por autoconstrução, autoajuda ou mutirão, administração direta e autogestão pelas cooperativas, associação e demais entidades da sociedade civil e empreitada global. Posteriormente, resultou na demanda de inclusão de um subprograma dentro do Programa Minha Casa Minha Vida, o Minha Casa Minha Vida Entidades, o qual tem, hoje, entre suas modalidades, (i) aquisição de terreno e construção; (ii) construção em terreno próprio ou de terceiros; (iii) aquisição de imóvel novo ou para requalificação; (iv) contratação direta com a Entidade Organizadora em terreno de sua propriedade para construção, como substituta temporária dos beneficiários, vinculada a contratação futura com os beneficiários finais; e (v) contratação direta com a Entidade Organizadora para aquisição de terreno, pagamento de assistência técnica e despesas com legalização, como substituta temporária dos beneficiários, vinculado à contratação futura para a produção das unidades habitacionais. A construção das unidades pode ser feita: (i) através da autoconstrução pelos próprios beneficiários; (ii) por mutirão ou autoajuda;

3 Algumas prefeituras passaram a disponibilizar o material e o terreno e promover mutirões para a produzir moradias populares. A crítica aqui é que o mutirante disponibiliza suas horas de lazer para produzir sua própria moradia, ou seja, horas de trabalho não pago, uma forma de exploração deste trabalhador baseado na justificativa da falta de moradia. 
(iii) por autogestão; (iv) por administração direta; e (v) por empreitada, de forma semelhante aos demais programas autogestionários.

Por mais que representem uma parcela bem menor de participação nos recursos do que o programa habitacional protagonizado pelas grandes empreiteiras, o Programa Crédito Solidário até 2011 havia financiado mais de $21 \mathrm{mil}$ unidades habitacionais em mais de vinte estados brasileiros, enquanto o Minha Casa Minha Vida Entidades até 2011 havia produzido mais de 9 mil moradias, em mais de 15 estados brasileiros, sendo que uma grande parcela deles está vinculada aos movimentos por moradia, como podemos ver no gráfico 1, o que nos mostra a conquista da autogestão nos espaços políticos públicos, demonstrando que é possível uma política habitacional construída com outros pressupostos e com outro formato.

PMCMV Entidades: $\mathbf{n}^{\circ}$ total de unidades habitacionais e de unidades habitacionais vinculadas aos movimentos nacionais de moradia, por estado.

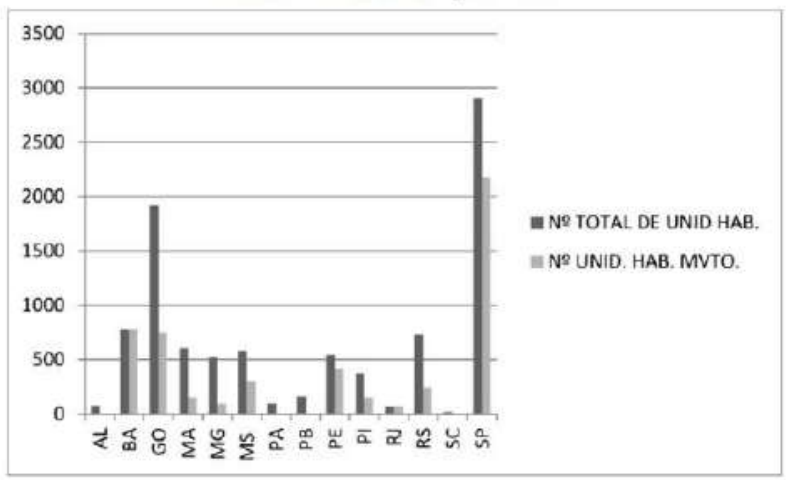

Fonte: Ministério das Cidades e coordenações nacionais da CMP, CONAM, MNLM e UNMP, 2012. IN: Ferreira, 2012. 
O contato entre a UNMP e a FUCVAM permanece constante como uma fonte de capacitação e integração dos movimentos sociais latino-americanos. Dentre as diretrizes perseguidas pelas cooperativas uruguaias, falta ao movimento por moradia brasileiro superar um entrave estrutural que diz respeito à propriedade coletiva das cooperativas, um dos eixos fundamentais do movimento no Uruguai. A luta pela coletivização, no entanto, trava uma batalha muito maior, ainda a ser perseguida, que diz respeito ao aspecto fundamental da sociedade brasileira: a propriedade privada, que é a base do poder econômico, político e da distinção social.

\section{Conclusão}

As duas sessões anteriores descreveram as trajetórias de formação do sistema de cooperativas autogestionárias uruguaias e do UNMP, cujo mérito inclui a articulação de um subprograma de moradias autogestionárias no programa habitacional Minha Casa Minha Vida. Nosso objetivo não era o de traçar com detalhes as trajetórias individuais de cada um deles e tampouco de comparar a influência que o primeiro exerceu no segundo ao apresentar-lhe novas possibilidades institucionais e arquitetônicas. Nosso propósito foi demonstrar a enorme mudança qualitativa promovida pela aproximação do UNMP com a FUCVAM, pois consideramos que até este encontro a pauta do movimento brasileiro esteve presa na dicotomia entre o público e o privado. Vimos que inicialmente as discussões no âmbito da moradia popular desacreditavam da iniciativa privada como forma de acesso à moradia, limitada pelos altos preços, pela especulação imobiliária e pela dificuldade de acesso ao financiamento de longo prazo para o segmento popular. Ao mesmo tempo, no entanto, após quase três décadas de Banco Nacional de Habitação e de uma política habitacional dita 
popular, também pouca ou nenhuma credibilidade tinha o Estado como uma instituição capaz de resolver o falso problema da habitação. $\mathrm{O}$ total descaso das políticas públicas com a população marginalizada e a proximidade entre $o$ Estado e as construtoras privadas, deixava evidente que a separação estre estes dois sujeitos era meramente formal, pois ambos respondiam a um único comando: o do capital.

No espaço entre a esfera pública e a privada, os movimentos por moradia popular buscavam outra forma de se posicionarem. Até o primeiro contato com a FUCVAM, a iniciativa destes pautava-se na produção por conta própria em terrenos públicos ou privados (ocupações) ou na demanda por habitações sociais. A partir do momento em que aderiu à produção por autogestão, foi possível ao movimento se organizar coletivamente e com pautas e demanda bem definidas, o aprendizado e a conscientização popular exigiam uma resposta do governo e atribuíam ao movimento por moradia um papel mais emancipador do que sua formulação anterior, pois nos espaços organizados em torno da autogestão, permite-se a discussão sobre a propriedade privada, sobre as origens do latifúndio e da concentração da terra urbana, indaga-se sobre a política habitacional anterior tanto em sua forma como em seus resultados e principalmente, coloca-se a questão dos limites da atuação estatal em resolver o "problema habitacional".

A característica por trás dos movimentos de cooperativas habitacionais por autogestão e ajuda mútua é a reversão dos elementos que constituem a racionalidade capitalista: a

4 Em seu texto seminal Gabriel Bolaffi desconstrói a ideia de que haja um problema de déficit habitacional. Pela contabilidade existe um estoque de casas correspondente ao número de pessoas que se declaram sem moradia, portanto o problema se recoloca na falta de acesso ao mercado de moradias, que é explicado por outros elementos: desigualdade de renda, preços exorbitantes dos imóveis etc. O discurso do déficit habitacional, na realidade, contribui para que se estabeleça uma série de políticas e estímulos ao mercado de moradias que, sobre este pretexto, garantem lucros para os segmentos da construção civil e permitem a especulação com o espaço urbano (Bolaffi, 1976). 
individualidade e a propriedade privada. Em contraponto a eles se constrói uma alternativa que se propõe antagônica, calcada na solidariedade e na noção do comum ${ }^{5}$. Este comum está bem definido na nova obra de Laval e Dardot (2017) e não diz respeito ao bem comum como análogo ao bem público, mas ao comum como a designação de um regime de lutas práticas, instituições e pesquisas que abrem as portas para um futuro não capitalista. Essa interpretação nos permite ir um pouco além das atribuições de David Harvey (2014) ao papel revolucionário das lutas urbanas. Para o autor é nestas formas de resistência urbanas comuns ao processo de espoliação urbana que se encontra a chave para um movimento revolucionário, o qual, no entanto necessita ser organizado e assumir caráter centralizado para ser o precursor de uma revolução urbana. O que se propõe aqui é que estas formas de organização do comum sejam incendiárias não porque contestam a apropriação do excedente produzido na cidade, mas porque se opoem à lógica privada e ao fazê-lo reverbera em todos aqueles expropriados. Trata-se, portanto de uma luta emancipatória e igualmente democrática, pois resulta na formação de uma altermundialização.

A declaração da altermundialização a partir da política habitacional pode parecer gananciosa, se avaliada superficialmente. A globalização totalizante e segregadora que nos é imposta, somada ao deslocamento epistemológico que orienta nossa formação acadêmica pode nos fazer crer que tais experiências sejam marginais e redundantes, no entanto a adesão ao Minha Casa Minha Vida Entidades, o número

5 A reivindicação do comum trazida à luz pelos movimentos sociais [...]é o princípio efetivo dos combates e movimentos que há duas décadas resistem à dinâmica do capital e conduzem a formas originais de ação e discurso. [...] pretendem opor-se à tendência dominante de nossa época: a ampliação da propriedade privada a todas as estas da sociedade, da cultura e da vida. Neste sentido, o termo "comum" designa não o ressurgimento de uma ideia comunista eterna, mas o surgimento de uma forma nova de contestar o capitalismo, ou mesmo de considerar sua superação. (página 16 e 17, Dardot, Laval, 2017) 
de unidades habitacionais produzidas, a abrangência das cooperativas autogestionárias no Uruguai e a "exportação" deste modelo para outros países da América Latina deixa evidente que este não é um processo isolado, uma resposta local a um problema circunstancial.

Ao contrário, trata-se de uma alternativa possível, vinda do sul global, que emancipa, é eficiente ${ }^{6}$ e mais importante contrapõe-se a lógica capitalista.

Desta forma, conclui-se comprovando que a principal importância atribuída à confluência destes movimentos refere-se à possibilidade de inclusão do movimento por moradia brasileiro na geografia das novas lutas insurgentes, que se apresentam como as alternativas à máquina capitalista e nos permite repensar a resistência, pois se o neoliberalismo se alimenta do efêmero, do específico, da quebra dos laços de solidariedade entre a classe trabalhadora ao propagar o individualismo como moral, um movimento que se propõe a antítese destes fatores é, inevitavelmente, revolucionário.

\section{Bibliografia}

Bolaffi, Gabriel. Habitação e urbanismo: o problema e o falso problema. Cadernos Universidade de São Paulo, Centro de Estudos Rurais e Urbanos, N 9, 1976.

Dardot, Pierre; Laval, Christian. Comum: ensaio sobre a revolução no século XXI. São Paulo: Boitempo, 2017.

6 O termo eficiente é usado aqui na ausência de termo melhor. Não sugiro que este modelo seja economicamente eficiente, proponho que ele seja eficiente no sentido que resolve o problema principal ao qual se propõe: construção de moradias populares a baixo custo e de qualidade. 
Ferreira, Regina F. Movimentos Sociais, autogestão e construção da política nacional de habitação no Brasil. In: Lago, Luciana (Org.), Autogestão habitacional no Brasil: utopias e contradições. Rio de Janeiro: Letra Capital: Observatório das Metrópoles, 2012.

Ferreira, Regina F. A autogestão habitacional no Brasil a partir do governo Lula: produção e agentes. In: Lago, Luciana (Org.), Autogestão habitacional no Brasil: utopias e contradições. Rio de Janeiro: Letra Capital: Observatório das Metrópoles, 2012.

Ghilardi, Flavio Henrique. Cinco décadas de cooperativismo de moradia no Uruguai. E-metropolis, ano 8, $\mathrm{N}^{\circ} 30$, set. 2017.

Nahoum, Benjamin. Algunas claves: reflexiones sobre aspectos esenciales de la vivienda cooperativa por ayuda mutua. Montevideo: Trilce, 2013.

Paz, Rosângela D. O fundo nacional de moradia popular: marco histórico de participação da união dos movimentos de moradia de São Paulo. 182 f. Dissertação (Mestrado) - Curso de serviço social, Pontifícia Universidade Católica de São Saulo, São Paulo, 1996.

Domínguez, Marta Solanas. FUCVAM: cooperativismo de vivienda, de los barrios en Montevideo a una alternativa contra hegemónica en otros Sures. Interface: a journal for and about social movements, vol. 9, $\mathrm{N}^{\circ} 1$, pp. 448-476, 2017. 



\title{
El proceso de renovación urbana en el centro metropolitano de Monterrey
}

\author{
Artistas y activistas: habitar el centro \\ como una forma de resistencia social
}

RebeCA Moreno ZúÑIga y Mario Alberto JuRAdo Montelongo

\section{Resumen}

Ante el discurso oficial de una zona abandonada por sus habitantes y en franco deterioro, que justifica una renovación urbana del centro metropolitano de Monterrey, es relevante analizar los cambios y dinamismos que el centro presenta hoy y que ocurren a la par del proceso de gentrificación que se viene desarrollando. Si bien el centro ha perdido habitantes aún existen en él barrios residenciales fácilmente identificables y nuevos habitantes que han decidido hacer de este un lugar para residir y/o efectuar proyectos culturales, sociales y hasta comerciales

En esta ponencia presentamos los resultados de nuestras observaciones y las entrevistas a artistas y activistas del centro de la ciudad de Monterrey como parte de uno de los objetivos planteados dentro del proyecto más amplio "Permanencias, transformaciones y tendencias. El proceso de gentrificación en el centro metropolitano de Monterrey". Nuestro objetivo consiste, entonces, en analizar las formas en que algunos habitantes, particularmente artistas 
y activistas, del centro metropolitano de Monterrey lo habitan como una forma de resistencia al proceso gentrificador que sufre este lugar.

\section{Palabras clave}

Gentrificación; gentrificación inmobiliaria; Centro metropolitano de Monterrey.

\section{Introducción}

Uno de los procesos de renovación urbana más importantes que ha experimentando el centro de Monterrey fue el desarrollado para la construcción de la Gran Plaza (conocida popularmente como la Macroplaza) en 1983. El proyecto fue una acción emprendida "con objeto de liberar terrenos en el centro de la ciudad para impulsar la inversión de actores privados" (Melé, 2006: 235) y edificar un gran distrito de negocios.

El discurso al que se recurrió fue el de la rehabilitación de un espacio de la ciudad decadente, en crisis, tal como lo refiere Enrique Torres, funcionario de la administración estatal de Martínez Domínguez: "Una de las razones por las cuales se construyó la Macroplaza fue regenerar una zona que estaba obsoleta" (entrevista con Enrique Torres López, director general de Agua y Drenaje durante el gobierno estatal de Alfonso Martínez Domínguez, 21 de febrero de 2008). Sin embargo, para Patrice Melé (2006), estudioso del caso, "la destrucción de un espacio urbano en crisis" (p. 239) no fue más que una dramatización que estigmatizaba la zona como peligrosa y conflictiva. En realidad se trataba de un espacio vivo, con funciones comerciales (por ejemplo las ópticas), recreativas (los cines) y habitacionales.

La Macroplaza no logró concretar los planes de convertir el centro de Monterrey en un Central Business Park, debido a que los inversionistas privados (los dueños de las 
grandes empresas regiomontanas) ya se habían adelantado a los planes del gobernador Martínez Domínguez y habían adquirido terrenos en San Pedro Garza García. En este municipio, en el que muchos tenían sus casas y en donde el precio de los mismos era accesible y había agua, se desarrolló la zona Valle Oriente, proyecto al que el gobierno no se opuso, contribuyendo al desarrollo de vialidades ${ }^{1}$ (Melé, 2006). Ante este revés, algunos compradores de los terrenos adyacentes a la Macroplaza congelaron los proyectos de construcción y esperaron el desarrollo de la zona.

Otras obras urbanas se realizaron en las sucesivas administraciones, tales como los llamados megaproyectos urbanos, Parque Fundidora, Línea 1 del Metro y Santa Lucía (primera etapa) (Garza, 2003). La principal característica de estas obras fue la entrada del capital privado en la realización de las mismas, que actuó de manera conjunta y bajo diversas modalidades con el Gobierno del Estado (coinvirtiendo o en comodato). En estos casos, la figura del fideicomiso fue esencial para permitir una mayor libertad de acción y de negociación al Estado. "El fideicomiso tiene como uno de sus objetivos centrales promover la inversión privada y crear los mecanismos de coparticipación entre el inversionista que financia el proyecto y el gobierno que concesiona el terreno por un largo período para garantizar su rentabilidad" (Garza: 2003: 186).

Dentro de estos megaproyectos urbanos, se planeó unir la Macroplaza con el Parque Fundidora ${ }^{2}$, creando un canal artificial en parte de lo que fue el río Santa Lucía. Primero se

1 Todavía, en esos primeros años de la década de los ochenta, los precios del terreno por metro cuadrado eran mayores alrededor de la Macroplaza que en la zona de Valle Oriente. La estrategia del gobierno estatal era financiarse con la diferencia obtenida entre la compra (o expropiación) y venta de los terrenos, de tal manera que, los empresarios participantes se convertirían en uno de los actores principales que ayudarían al gobierno estatal a recuperar la inversión de la construcción de la Macroplaza (Fitch, Iga, Murguía, 2007).

2 Fundidora de Monterrey fue una de las grandes empresas que dieron origen a la industrialización de la ciudad de Monterrey a principios del siglo xx. En 1986 se cierra esta fuente de trabajo que daba empleo a más de 6 mil trabaja- 
empezó en 1993, la construcción de la Plaza de los 400 años y el Museo de Historia Mexicana (Garza, 2003). Posteriormente, se construyó un auditorio al aire libre, se extendió el canal y se construyeron los andadores, la plazoleta y los jardines; todos inaugurados en junio de 1996. Dado que, tanto los fondos públicos como el crédito estaban agotados, el fideicomiso comercializó el patrimonio inmobiliario. A finales de 2001 no se habían edificado comercios y residencias, como estaba proyectado, y se presentaba el riesgo de correr con la misma suerte que cuando se construyó la Macroplaza, ya que esta es una zona de sectores bajos y populares (Garza, 2003).

Lo que se conoce como la segunda etapa del Paseo Santa Lucía, se inició durante el gobierno estatal de Natividad González Parás. Santa Lucía se proyectó como el escenario de un evento cultural de dimensiones internacionales: el Fórum Universal de las Culturas Monterrey 2007.

Estas obras de renovación urbana, contienen algunos rasgos de gentrificación, entendida esta como el "fenómeno de reconquista de las áreas centrales y de las zonas consolidadas de las ciudades por el poder económico, particularmente cuando se trata de la apropiación de esos espacios por parte de los agentes inmobiliarios privados y sus operaciones de capitalización de renta del suelo" (Casgrain y Janoshka, 2013, p. 21).

Los cambios han ocurrido bajo el liderazgo del gobierno estatal que ha tenido como objetivo construir condiciones para motivar la inversión privada en los espacios liberados. El trabajo de destrucción, regeneración, renovación y rehabilitación de espacios urbanos en el centro de la ciudad de Monterrey tuvo efectos en la imagen externa de la Zona Metropolitana, a tal grado que aumentó y reorientó el flujo de turistas hacia estos espacios urbanos.

dores. Su área de 142 hectáreas, en 1988, se transforma en un gran parque ecológico por decreto del gobierno federal. Actualmente más del 50\% de su espacio está privatizado y se usa para fines comerciales (Jurado, 2016). 
Explícitamente, no han existido obras de este tipo destinadas a mejorar la calidad de vida de la población residente del centro de la ciudad. No obstante, tuvieron efecto en su funcionalidad, principalmente, se tradujeron en una expulsión de población de las zonas de renovación y de las aledañas ${ }^{3}$.

De acuerdo a la interpretación de estos "macroproyectos" se considera que responden más a fortalecer la imagen de la ciudad que a transformar la ciudad real (Prieto, 2011); a trivializar el patrimonio histórico de la ciudad (Casas, 2015) o a crear una marca de ciudad (Moreno, 2016).

Actualmente, según El Plan de Desarrollo Urbano de Monterrey 2013-2025, existen propuestas municipales que van destinadas a una racionalización de los espacios urbanos del centro de la ciudad, haciendo énfasis en los usos mixtos del suelo, pero aún no se han implementados claramente. Una de las actuales preocupaciones en el centro de la ciudad es la existencia de 1.200 viviendas abandonadas, por eso es que el Plan contempla un redensificación de este espacio urbano.

El centro de la ciudad de Monterrey ha sido importante desde principios del siglo XX como una zona de residencias de la población de altos ingresos, hasta los años cincuenta, cuando paulatinamente este grupo de pobladores empezó a ubicarse en las zonas aledañas y posteriormente, en una segunda etapa, se movilizaron hacia el poniente de la ciudad y hacia otro municipio asentado en las faldas de la Sierra Madre. También, conviene comentar que en los años treinta y cuarenta del siglo XX se empezó a desarrollar un asentamiento de población de clase media en el centro de la ciudad, en una zona intermedia entre la ubicación de

3 Fue un desplazamiento inmediato de la población que vivía en las áreas y en las aledañas de destrucción y renovación. Pero también debemos de considerar a la población que posteriormente tuvo que emigrar del centro debido a que las nuevas obras crearon zonas comerciales y de entretenimiento que alteraron las condiciones de vida comunitaria al aumentar el ruido, la contaminación y el tráfico y, por lo tanto, disminuir la calidad de vida. 
las grandes empresas industriales (como Vitro y Cervecería) y el casco antiguo de la ciudad. Así, se formaron y/ o fortalecieron los barrios de la Luz, de El Chorro, entre otros (Tamez, 2007).

Lo que ha pasado en este centro de la ciudad de Monterrey es que el proceso de movilidad voluntaria de parte de la clase alta hacia otros espacios de la zona urbana y esta aparente expulsión de la clase media, que ha iniciado en los años ochenta y noventa, ${ }^{4}$, no ha tenido, actualmente, su contraparte como una "recuperación" de este apreciado espacio central. Cavazos (2007) ha mencionado que después del abandono de las antiguas familias del centro de la ciudad, se empezó una "obra destructiva" que se reflejó en una pérdida de identidad (p. 25).

Por eso no es raro que se hable del centro como un lugar abandonado, sujeto a la anarquía, al deterioro y a la falta de identidad. Entonces, la cotidianidad de la gente que habita el centro actualmente se la puede considerar como una señal de resistencia frente al proyecto hegemónico de recuperación comercial y "residencial" promovido desde los gobiernos estatales y municipales. Esta cruzada oficial para capitalizar y concentrar los espacios urbanos en beneficio de intereses privados poco a poco se ha estado fortaleciendo con los proyectos verticales que actualmente se están desarrollando en la Zona Metropolitana de Monterrey. Prácticamente el $24 \%$ de estos proyectos que se están construyendo son en el centro de Monterrey (De la Rosa, 2017).

4 No conocemos sobre este proceso, suponemos su existencia, tomando en cuenta que se ha dado un despoblamiento del centro de la ciudad del 50\% de acuerdo a los datos de los censos de población de 1990 y del 2010 (Salgado, 2006; INEGI, 2010). No obstante, es un proceso que está en una nueva etapa ya que en la década del 2000 al 2010 se ha estado observando un relativo repoblamiento que ha estado deteniendo esta tendencia hacia el despoblamiento agudo. La repoblación se realiza por dos vías: mediante la construcción de vivienda vertical por el capital inmobiliario y por la llegada espontánea de jóvenes y adultos profesionistas que utilizan el tipo de vivienda horizontal ya existente y en algunos casos le realizan renovaciones parciales, de acuerdo al estilo de vida que buscan desarrollar. 
Así es importante dar cuenta de esta resistencia de la población residente, en ocasiones involuntaria, que al igual que los intereses fortalecidos por el capital inmobiliario, intentan aprovechar y explotar racionalmente la ubicación privilegiada del centro reflejada en la oferta de servicios urbanos y bajos costos de traslado.

Nuestro objetivo consiste, entonces, en analizar las formas en que algunos habitantes, particularmente artistas y activistas, del centro metropolitano de Monterrey, lo habitan como una forma de resistencia al proceso gentrificador que sufre este lugar.

\section{Planteamiento del problema}

Al centro se le llama "el primer cuadro" de Monterrey, que hasta antes de finales del siglo XIX, era el lugar del comercio, de los servicios, de las empresas, de la administración de la ciudad y de la residencia de sus habitantes. Con la industrialización, llegaron los espacios exclusivamente residenciales. Las primeras colonias crecieron alrededor de la industria que se había instalado en las periferias de este primer cuadro. La industria empezó a impulsar a los barrios obreros aledaños a los centros de trabajo, como la colonia obrera en la zona oriente, enseguida de Fundidora; la colonia Vidriera en la zona norte, enseguida de la empresa Vidriera Monterrey, entre otras colonias.

El centro ha perdido residentes, pero aún existen en él barrios residenciales fácilmente identificables (barrio de La Luz, barrio de la Purísima, barrio Mediterráneo, entre otros) y nuevos habitantes que han decidido hacer del centro un lugar para residir o para efectuar proyectos culturales, sociales y hasta comerciales en él.

En este momento se pueden identificar, al menos, cuatro procesos en el primer cuadro de la ciudad que pudieran llevarnos a desarrollar un proyecto de investigación sobre lo que está ocurriendo en él y hacer prospectiva sobre este. 
Primero, se observan una serie de actividades que podemos denominar como parte del proyecto de vida de personas y colectivos tendientes a reproducir una forma de vida recreativa, artística y cultural. Tal es el caso de la aparición de pequeños cafés, algunos de los cuales son gay friendly, mercados de productos artesanales y orgánicos, talleres de serigrafía, escuelas de bailes, creación de banquetas artísticas, entre otras.

En segundo lugar y particularmente después de los momentos más álgidos de violencia, empezamos a observar una serie de actividades económico-comerciales tendientes a revitalizar el centro, en este sentido, tales como la construcción de edificios de departamentos (La Capital, El Semillero, entre otros), restaurantes de comida vegana, o proyectos multifuncionales, como el Pabellón M.

Un tercer proceso, que cuenta de manera más clara de la ciudad neoliberal es la liberalización de terrenos para su comercialización, expresada a través del derrumbe de casonas dejando algunas manzanas libres para su venta. Baste con dar un vistazo del primer cuadro de la ciudad en Google maps comparando 2009 y $2016 .{ }^{5}$

Por último, también se observa la ampliación espacial de algunas instituciones sobre las manzanas aledañas a su sede original, como lo evidencia la extensión que han experimentado algunas universidades privadas, residentes en el centro de la ciudad, como la Universidad Metropolitana

5 En esta revisión notamos que, primero, se realiza un proceso de compra venta del bien inmueble y después una destrucción de la construcción que existe en el predio. Posteriormente, se reactiva un proceso de compraventa del lote baldío a precios más altos. Un tercer paso es la generación de un proyecto de construcción que pasa por la evaluación municipal, que últimamente ha sido muy permisiva, y finalmente se presenta una nueva construcción comercial, de servicios y en algunas ocasiones residencial, pero siempre bajo la forma de vivienda vertical. El otro tipo de proceso es el de renovación que busca aprovechar lo ya existente, generando un proyecto que transforma sin destruir. Pero está predominando el proceso de destrucciónconstrucción que está terminando paulatinamente con el modelo de vivienda de finales del siglo xix y principios del siglo xx y que utilizaba al sillar como principal material de construcción. 
de Monterrey y la Universidad Regiomontana; así también, algunos sindicatos, como el de los Trabajadores del Estado y el Sindicatos de Trabajadores Independientes, entre otros.

Los centros metropolitanos son zonas de uso heterogéneo, no predominan usos del suelo determinados como sí sucede en las periferias (Coulomb, 2009). Por eso es que al interior del centro metropolitano, sobre todo el histórico, se pueden detectar diferencias que pueden llevarnos a zonificarlo, donde predominan algunos rubros comerciales o de servicios, o donde aún existe un predominio habitacional o, finalmente, donde se desarrolla un uso del suelo mixto.

La manera de acercarnos al propósito de esta investigación parte de la existencia de varias zonas de residencia que pueden ser identificadas por símbolos urbanos, puntos de referencia o núcleos de población: Barrio la Luz; Barrio Antiguo; zona de la Purísima; Condominios Constitución; Zona de Santa Lucía; Calle Venustiano Carranza; Escuela Plutarco Elías Calles; Alameda; Central de autobuses, etc. El alcance de cada zona está determinado por el habitante o residente que se identifica con algunos símbolos o actividades (Casas, 2007).

Un texto de Salgado (2006) que analiza el proceso de renovación del Barrio Antiguo concluye que la inversión pública no llevó a un proceso de gentrificación, sino a un proceso basado en la rentabilidad de los usos del suelo. Esto permitió a los inversionistas desdeñar el desarrollo o rehabilitación de vivienda, porque la rentabilidad del uso del suelo residencial es mucho más bajo que el comercial $\mathrm{y}$ de servicios.

Por eso es que ahora las autoridades municipales buscan promocionar la inversión privada en edificios con usos del suelo mixtos. Con ello se buscaría aprovechar la plusvalía del terreno para impulsar también el proceso de gentrificación habitacional en el centro de la ciudad. ¿Pero qué tanto se está logrando? ¿Y cómo lo visualizan los residentes? 


\section{Marco teórico/marco conceptual}

María Carla Rodríguez (2015) apunta que las ciudades han sido el escenario de la reestructuración urbana y las políticas neoliberales, donde los componentes urbanos se volvieron objeto de especulación. Así, la ciudad sirve a los intereses del capital y es apropiada mercantilmente, el Estado es aquí el principal orquestador (Díaz, 2015).

El papel de Estado ha sido estratégico para la entrada de los inversionistas inmobiliarios en las ciudades:

Las políticas neoliberales implicaron un cambio en la presencia, injerencia y responsabilidades del Estado [...] la construcción y consolidación de nuevas institucionalidades estatales orientadas a facilitar todo tipo de instrumentos privados con fines de negocios junto con la privatización y desregulación destinadas a construir nuevas áreas de ganancias: empresas públicas, impuestos, reformas laborales, operaciones financieras. (Rodríguez, 2015, p. 210)

En los casos más extremos el Estado puede participar en las acciones de desposesión del patrimonio de familias y personas de bajos recursos, al igual que dotar de cierta infraestructura a áreas de la ciudad a las que desea que llegue la inversión privada; asimismo, elabora discursos sobre el deterioro y la amenaza de ciertas áreas de la ciudad, particularmente el centro, para avalar y crear un consenso en torno a acciones de rehabilitación y reestructuración urbana que emprende en conjunto con la iniciativa privada.

En América Latina, el Estado ha emprendido una serie de "acciones estratégicas para adecuar las ciudades a las nuevas necesidades de acumulación del capital" (Díaz, 2015, p. 14). La gentrificación es una manifestación de lo antes dicho, una primera oleada aparece en la década de los ochenta principalmente vinculada a los centros históricos, muchos de los cuales fueron declarados patrimonio de la 
humanidad por la UNESCO. Estos lugares, reúnen una serie de condiciones que logran el desarrollo de los sectores inmobiliarios y turísticos (Díaz, 2015).

A diferencia de las primeras expresiones de la gentrificación estudiadas por Ruth Glass ${ }^{6}$ en el contexto del Estado de bienestar, la gentrificación latinoamericana se enmarca en el neoliberalismo (Rodríguez, 2015; Brenner, Peck, Theodore, 2015). Ibán Díaz (2015) identifica cuatro aspectos claves de este proceso en la región latinoamericana: 1) la primacía de las políticas públicas en dicho proceso; 2) la relevancia de los centros o lugares históricos; 3) el patrimonio y su uso turístico y comercial y 4) la movilización de las clases populares para dificultar los procesos y la vulnerabilidad que como consumidores en este proceso tienen las clases medias.

Al respecto, Ricardo Gómez (2015) señala que en la región se establecen una serie de políticas públicas tendientes a beneficiar a los agentes inmobiliarios. Se han creado nuevos mercados inmobiliarios cuyas manifestaciones más claras son la privatización y los cotos cerrados tanto en el centro de las ciudades como en la periferia. Por último, aparecen los actores más importantes en este proceso, los consumidores de la gentrificación o los latino-gentrificadores, es decir "la gente conectada con los trabajos del sector terciario y de ingresos medios que elige los barrios centrales, incluyendo jóvenes profesionistas, viviendo solos o en pareja, con o sin hijos" (Gómez, 2015, p. 367).

\section{La movilización y resistencia de las clases populares}

Como ya se señaló anteriormente, la gentrificación en Latinoamérica se da en el marco del neoliberalismo, siendo los sectores populares los más afectados, pues el cambio de

6 Ruth Glass fue quien acuñó el término gentrificación para mostrar el desplazamiento de la clase obrera por miembros de la clase media en el Londres de mediados del siglo XX (Olivera, 2015). 
escenario (gentrificación simbólica), las alzas en las rentas del suelo y el cambio en su uso les obligan al desplazamiento. Sin embargo, no podemos suponerlos pasivos a los cambios que sufre el lugar en el que habitan, en el cual han construido una memoria colectiva y han experimentado su trayectoria de vida.

Algunas personas pensarán que los pobres también sacan ventaja al vender sus casas al mejor precio; no debemos perder de vista que casi siempre se usan recursos normativos para que sus viviendas sean entregadas: cotizar las viviendas según su valor catastral y no comercial y usar el recurso de expropiación; esto sin contar que la gentrificación simbólica también desplaza a las personas al ir desapareciendo formas tradicionales de consumo y lugares que reproducen la memoria colectiva. Consideremos que esta apropiación de los espacios urbanos por parte de los agentes inmobiliarios urbanos privados ocurre bajo una acumulación por desposesión.

Casgrain y Janoschka (2013) consideran importante revisar la resistencia a la gentrificación, lo cual implica analizar el dinamismo de las prácticas sociales y dejar de ver fenómenos como el que aquí se analiza de una manera estática. La resistencia que aquí nos ocupa es la de artistas y activistas que desarrollan sus actividades en el centro metropolitano de Monterrey.

\section{Metodología}

Los resultados que aquí se presentan son parte de un proyecto más amplio titulado "Permanencias, transformaciones y tendencias. El proceso de gentrificación en el Centro metropolitano de Monterrey". La metodología que hemos utilizado para el desarrollo de este proyecto y de los resultados parciales que exponemos sigue un enfoque cualitativo de carácter exploratorio. Las técnicas utilizadas para la 
recolección de los datos han sido las observaciones in situ, a través de recorrido a pie por el centro metropolitano; el mapeo de manzanas que componen la zona, a través de Google maps comparando dos momentos, 2008 y 2016, y las entrevistas semiestructuradas de final abierto.

\section{Análisis y discusión de datos}

\section{Habitar el centro como forma de resistencia}

En este trabajo consideramos que el discurso de un centro abandonado, decadente y peligroso manejado por el Estado y difundido por los medios de comunicación ha sido un recurso utilizado para justificar la obras de reestructuración urbana realizadas por el gobierno del estado de Nuevo León y que tiene sus antecedentes en la destrucción que ocasionó la edificación de la Macroplaza. Si bien podemos considerar que existen amplias zonas del centro abandonadas, esto obedece a diversas causas, por una parte, algunos de estos terrenos son producto de la liberalización de terrenos que vía expropiación se hicieron a los habitantes durante las obras de la Macroplaza y el Paseo Santa Lucía; otra causa se debe a las propiedades intestadas o a los elevados precios de venta, que no han sido regulados por el Estado, ni en el monto, ni en el tiempo de venta. Sin embargo no puede considerarse el total abandono del centro, este sigue vivo y con una existencia muy dinámica.

Los entrevistados fueron activistas, artistas y comerciantes o prestadores de servicios, algunos combinan dos o más de las actividades mencionados, sus edades van de los 40 a los 50 años, todos son hombres y se dedican al activismo social, la promotoría cultural y las actividades comerciales de nuevo cuño (restaurantes gourmets, tiendas vintage o de productos artesanales); los colectivos a los que pertenecen son La banqueta se respeta, Caminando en mi 
barrio y Vecinos del Centro de Monterrey. La mayoría de ellos llegó a vivir al centro en los años noventa o principios de los dos mil.

Los entrevistados refieren que vivir en el centro es lo mejor que les ha pasado, esta experiencia fue antecedida por una idea muy romántica del centro. Así se lee en los siguientes comentarios: "El centro es un lugar más bohemio que cualquier otro"7; "Yo soy un enamorado del centro, soy regiomontano y siempre he admirado el Barrio Antiguo... decía algún día voy a vivir en Santa Lucía"; "Yo crecí en San Nicolás... y el centro era como ¡wow!, era excitante, era padre ir al centro... yo tenía la idea del centro como el lugar"; "Como que se crea otro cosmos, otra forma de ver y estar en la vida... hay una frase que les digo a mis amigos y familiares 'vivir fuera del centro es vivir en el error". ${ }^{10}$

Así también se expresaron sobre las ventajas de habitar este centro metropolitano. Una de las más mencionadas fue el ahorro en los traslados, ya que la movilidad en el centro se hace a pie o con bicicletas; por esta misma razón el uso del coche queda reducido a los trayectos que se hacen a los municipios metropolitanos. Casi todos los entrevistados refirieron haber vivido en la periferia del área metropolitana y haber tardado de una hora a hora y media para llegar a su trabajo o a sus actividades cotidianas. La realización de diversas actividades laborales y/o colectivas son parte de las ventajas que señalaron los entrevistados:

7 Entrevista realizada al artista, músico, diseñador y activista Chucho Colate, 12 de diciembre de 2016, Monterrey, N. L.

8 Entrevista a Luis Berzosa, ingeniero, promotor cultural y activista, 20 de julio de 2016, Monterrey, N. L.

9 Entrevista a Saúl Escobedo, artista y activista, 17 de agosto de 2015, Monterrey, N. L.

10 Entrevista a Ángel Sendic, artesano, comerciante y promotor cultural, 12 de julio de 2017, Monterrey, N. L. 
Buscábamos tener acceso a nuestro trabajo, a nuestras actividades, somos artistas, gente dedicada a la cultura, al arte, a la música, al video, a la foto, entonces aquí en el centro siempre ha sido el centro de actividades de todas estas áreas. ${ }^{11}$

Asimismo, las desventajas de habitar el espacio central, de acuerdo a las personas entrevistadas, son el descuido de la infraestructura y el equipamiento urbano: falta de luminarias, banquetas inadecuadas para caminar, la basura en la calles; la inseguridad de algunas áreas -algunos comentaron que fueron asaltados-; el ruido causado por el transporte urbano y la celebraciones de manifestaciones públicas, como las finales de fútbol o las peregrinaciones al Santuario de la Virgen de Guadalupe.

\section{El activismo social como forma de resistencia}

Una de las razones más importantes que está presente en los informantes es el activismo social y la promotoría cultural. $\mathrm{Al}$ respecto, Luis Berzosa (2016) apunta

Pertenezco al colectivo Caminando en mi Barrio, donde pues hacemos el trabajo de las banquetas [...] con una técnica que se llama trencadis, que es utilizar los mosaicos rotos y con eso se forma arte. Bueno, nuestro colectivo está utilizando esta técnica artística para crear comunidad, que fue precisamente lo que se creó en el barrio El Neyajote.

El remozamiento de las banquetas bajo la técnica referida, de acuerdo a Luis Berzosa, ha hecho partícipes a los vecinos, de inicio son los vecinos los que deben autorizar la intervención en las banquetas; su participación ha consistido en la aplicación de la técnica o se acercan a observar, a conversar, lo que ha potencializado la convivencia entre

11 Entrevista a Saúl Escobedo. 
vecinos y con los integrantes del colectivo. Asimismo, esta intervención ha propiciado, en parte, el cuidado y arreglo de las casas por parte de los propietarios.

Saúl Escobedo, artista, integrante del colectivo Vecinos del Centro de Monterrey y habitante del centro por más de una década, ha consolidado una asociación de vecinos de los barrios Mediterráneo y Purísima, quiene se reúnen todos los martes por la noche, desde hace ya cuatro.años. La mayoría de los que están en este grupo son antiguos propietarios cuya propuesta es proteger el patrimonio arquitectónico del centro; tienen miedo de que los grandes edificios que les tapen la vista, el aire, el sol. Se han estado informando de los planes de reestructuración urbana que el gobierno del estado de Nuevo León tiene en conjunto con las empresas inmobiliarias y están objetando el discurso oficial que dice "en el centro no vive nadie". El grupo también tiene presencia en las redes sociales, a través de Facebook, donde la mayoría de los integrantes son jóvenes. Aunque pareciera que son dos grupos sin comunicación alguna, tanto unos como otros saben acerca de lo que se debate en cada uno de ellos, esto es gracias a los interlocutores, que informan a ambos grupos de integrantes del colectivo.

Los colectivos a los que se hace referencia están compuestos tanto por los antiguos habitantes del centro como por los recién llegados. Ambos tiene una idea clara de rescate del centro: si bien abogan por una renovación del centro, esta debe hacerse sin dañar el patrimonio arquitectónico del lugar y respetando las áreas habitacionales. Estos grupos tienden a oponerse a la gentrificación de los grandes grupos inmobiliarios. 


\section{Conclusiones}

Actualmente la Zona Metropolitana de Monterrey tiene un poco más de cuatro millones de habitantes y está compuesta por nueve municipios. El centro de Monterrey ha tenido una relevancia en los últimos años debido a que la zona urbana ha crecido de forma extensa y desordenada, de tal manera que vivir actualmente en las periferias de esta gran metrópoli resulta altamente costoso, ya que los centros educativos y de trabajo están relativamente lejos de las zonas residenciales. Por eso, las autoridades han considerado impulsar las construcciones verticales, sobre todo, las que se concentren en el centro urbano o a su alrededor, ya que con esto se busca acercar al trabajador a su fuente de trabajo y así disminuir el uso de los vehículos motorizados. Los proyectos que se están promocionando y autorizando son los que contemplen el uso mixto del suelo. El problema radica en que estas opciones están destinadas a una población de altos ingresos, lo que limita el plan exitoso de renovación del centro y reduce sus beneficios sociales.

Fuera de estos planes, existe una población de jóvenes y adultos profesionistas que con sus propios proyectos y estilos de vida han decidido espontáneamente también acercarse a una zona que les permita tener una vida más integral, donde puedan desarrollar todas sus actividades cotidianas sin tener que desplazarse en automóvil. En este texto nos referimos a un grupo de este sector que se han instalado en el centro de la ciudad y que se dedican a actividades creativas y artísticas. En cierta manera ellos también con sus actividades están transformando simbólicamente el centro, ya que observamos una gentrificación que implica el establecimiento de nuevos sonidos (la música de los antros del Barrio Antiguo), olores (el de los cafés y los restaurantes veganos) y sabores.

Entonces, de la mano de esta última gentrificación han llegado nuevos habitantes al centro, algunos en los años noventa y otros a principios de los dos mil, quienes se han 
opuesto a la gentrificación inmobiliaria y han emprendido una serie de actividades artísticas culturales y de intervención social como forma de resistencia. Estas acciones han incluido a los vecinos de más antigüedad y se ha desarrollado una consciencia de lo que está ocurriendo en el centro metropolitano de Monterrey.

\section{Bibliografía}

Bojórquez Luque, Jesús; Villa, Manuel Ángeles (2014). Expansión turística y acumulación por desposesión: el caso de Cabo San Lucas, Baja California Sur. En Cuadernos de Geografía. Revista Colombiana de Geografía, vol. 23, $\mathrm{N}^{\circ}$ 2, julio-diciembre, pp. 179-202. Universidad Nacional de Colombia, Bogotá, Colombia. Disponible en: https://bit.ly/31k9riu.

Brenner, Neil. Jamie Peck y Nik Theodore (2015). Urbanismo neoliberal. La ciudad y el imperio de los mercados. En El mercado contra la ciudad. Sobre globalización, gentrificación y politicas urbanas. Madrid: Observatorio Urbano, Traficantes de sueños Editora, pp. 211-244.

Cabrales, Luis Felipe (2000). La rehabilitación del barrio antiguo de Monterrey. En Barbara Klauke (coord.), México y sus perspectivas para el siglo XXI. CELA.

Casas García, Juan Manuel (2007). Regeneración de los centros urbanos. Desarrollo y desarrollismo, apuntes para su contexto. En Rizoma, Revista de Cultura Urbana, $\mathrm{N}^{\circ} 6$, octubre-diciembre, pp. 20-23.

Casas García, Juan Manuel (2010). Del barrio San Luisito a la colonia Independencia. En Camilo Contreras (coord.), Colores y ecos de la colonia Independencia. Municipio de Monterrey, El Colegio de la Frontera Norte, pp. 15-33.

Casas García, Juan Manuel (2012). Concreto y efímero. Catálogo de arquitectura civil 1920-1960. CONARTE, p. 332. 
Casas García, Juan Manuel (2015). Imaginarios interrumpidos. Ensayo sobre el patrimonio inmueble perdido de Monterrey. Fondo Editorial de Nuevo León. CONARTE, CONACULTA, p. 279.

Casgrain, Antoine; Janoschka, Michael (2013). Gentrificación y resistencia en las ciudades latinoamericanas. El ejemplo de Santiago de Chile. Andamios, Revista de Investigación Social, vol. 10, $\mathrm{N}^{\circ} 22$, mayo-agosto, pp. $19-44$.

Cavazos Garza, Israel (2007). Urbanismo e identidad de Monterrey. En Rizoma, Revista de Cultura Urbana, $\mathrm{N}^{\circ} 6$, octubre-diciembre, pp. 24-25.

Coulomb, René (2009). Regeneración urbana y habitabilidad en los centros de ciudad. Lo aprendido en la ciudad de México. Conferencia en Encuentro Latinoamericano sobre centros históricos. San Salvador, 5 y 6 de mayo.

Dela Rosa, Rogelio (2017). Se espera el regreso de oficinas al centro. En Periódico El Norte. Sección Bienes Raíces, 29 de octubre.

Díaz, Ibán (2015). Introducción. Perpectivas del estudio de la gentrificación en América Latina. En Víctor Delgadillo, Ibán Díaz y Luis Salinas (coords.), Perspectivas del estudio de la gentrificación en México y América Latina. México: UNAM, Instituto de Geografía.

Fitch Osuna, Jesús; Carlos Iga y Ricardo Murguía (2007). Aproximación a la valuación socioeconómica del espacio público. Macro Plaza en Monterrey, México. En AEDIFICARE. Anuario se Investigaciones de la Facultad de Arquitectura, UANL, pp. 175-201.

García Ortega, Roberto; Belem I. Vásquez; María del Socorro Arzaluz y Alejandro García (2009). Monterrey, origen y destino. Tomo VI. Monterrey en la globalización: el despegue hacia la ciudad del conocimiento en los albores del siglo XXI, p. 246.

Garza, Gustavo; Pierre Filion y Gary Sands (2003). Politicas urbanas en grandes metrópolis: Detroit, Monterrey y Toronto. El Colegio de México, México, p. 402. 
Gobierno municipal de Monterrey (2014). Plan de Desarrollo urbano del municipio de Monterrey, 2013-2015. Gaceta Municipal. Órgano informativo del Ayuntamiento de Monterrey.

Gómez, Ricardo (2015). Gentrificación, fragmentación urbana y mercado inmobiliario. En Víctor Delgadillo, Ibán Díaz y Luis Salinas (coords.), Perspectivas del estudio de la gentrificación en México y América Latina. México: UNAM, Instituto de Geografía, pp. 263-380.

Jurado, Mario Alberto (2016). Parque Fundidora: ¿espacio público o privado? En Milenio, 30 de abril. Consultado el 27 de diciembre de 2017 en https://bit.ly/2Mz2mr4. INEGI (1990). Censo de Población y Vivienda 1990.

INEGI (2010). Censo de Población y Vivienda 2010.

Moreno, Rebeca (2016). La invención de la ciudad del conocimiento. Monterrey en la antesala de la violencia social [en línea]. Ciudad de Buenos Aires: Estudios Sociológicos. Disponible en https://bit.ly/2QUUdMc.

Melé, Patrice (2006). La producción del patrimonio urbano. México: Ediciones de la Casa Chata, CIESAS.

Narváez Tijerina, Adolfo (2006). Los condominios constitución. Historia de dos ciudades. En Camilo Contreras y Adolfo Benito Narváez Tijerina (coords.), La experiencia de la ciudad y el trabajo como espacios de vida. Monterrey: El Colegio de la Frontera Norte, UANL y PyV Editores, pp. 135-156.

Prieto, José Manuel (2016). Lo humilde en un contexto de grandeza. Desafíos que enfrenta la regeneración del Barrio Antiguo en Monterrey (Nuevo León). En Contexto. Revista de la Facultad de Arquitectura de la Universidad Autónoma de Nuevo León, vol. X, $\mathrm{N}^{\circ}$ 12, marzo, pp. 11-28.

Prieto, José Manuel (2011). La consolidación del Monterrey "imaginario" en el contexto de la globalización: "Macroproyectos" urbanos. En Frontera Norte, vol. 23, $\mathrm{N}^{\circ}$ 45, enero-junio, pp. 163-192. 
Rodríguez, María Carla (2015). Estado, clases y gentrificación. La política urbana como campo de disputa en tres barrios de Ciudad de Buenos Aires. En Víctor Delgadillo, Ibán Díaz y Luis Salinas (coords.), Perspectivas del estudio de la gentrificación en México y América Latina. México: UNAM, Instituto de Gepgrafía, pp. 205-229.

Salgado Gómez, Antonio (2006). El Barrio antiguo de Monterrey. ¿Tradición a pesar de todo, o transformación a cualquier costo? En Camilo Contreras y Adolfo Benito Narváez Tijerina (coords.), La experiencia de la ciudad y el trabajo como espacios de vida. El Colegio de la Frontera Norte, UANL y PyV Editores, México, pp. 157-197.

Tamez Tejeda, Antonio (2005). El centro de Monterrey (1950-2000): Arquitectura y ambiente urbano, su relación con la emergencia de nuevas centralidades urbanas. En AEDIFICARE. Anuario se Investigaciones de la Facultad de Arquitectura, UANL, pp. 213-251. 



\title{
Prácticas e identidades indígenas en contexto de ciudad
}

\author{
El caso de la comunidad indígena Nasa \\ del Cauca, en Bogotá, Colombia
}

\author{
AStRID LORENA RONCANCIO Alfaro
}

\section{Resumen}

El propósito de esta ponencia es evidenciar el resultado de una investigación que tiene como objetivo responder a un análisis sobre las implicaciones en las prácticas e identidades de la comunidad indígena Nasa luego de su proceso de desplazamiento desde el departamento de Cauca hacia la ciudad de Bogotá D.C. en el año 2017.

Para dar lugar a tal objetivo general, se buscó comprender el contexto que favoreció el desplazamiento de la comunidad indígena Nasa hacia la ciudad de Bogotá; cuáles son las transformaciones en las prácticas indígenas del pueblo Nasa perteneciente al Cabildo Nasa en Bogotá y cómo se configura la identidad en la comunidad indígena Nasa en contexto de ciudad.

Es importante resaltar cómo en el contexto colombiano la presencia de multinacionales en territorios rurales, la transversalización de múltiples actores armados legales e ilegales en los campos, la centralización de instituciones en lo urbano, etc., han posibilitado el ambiente propicio para que se intensifiquen procesos de desplazamiento masivos de lo rural hacia lo urbano, convirtiendo así a la ciudad en otro lugar posible de habitar para las comunidades indígenas. 
El espacio rural ha sido pues aquel lugar escogido desde la misma comunidad indígena y desde muchas visiones académicas para pensarse la pervivencia de los pueblos indígenas, no obstante, cuando por razones forzadas o voluntarias estas mismas comunidades deciden habitar la ciudad, el panorama se complejiza.

En términos teóricos la ciudad es un espacio social que se produce, una composición social que supera la conceptualización cerrada y única del espacio como infraestructura física. De tal manera que la ciudad viene a ser mucho más: un lugar de construcción y reconstrucción de la vida social y cultural, un espacio que tiene la facultad de ser lugar de encuentro de la diversidad. Desde esta perspectiva sería posible repensar la ciudad como un lugar posible de habitar para las comunidades indígenas desde las prácticas e identidades propias. Ahora bien, si la ciudad como centro cosmopolita es lugar de encuentro de muchas culturas, es un lugar que está en constante debate, en continua reconceptualización, un lugar de múltiples luchas y resistencias sociales; en otras palabras, es un territorio en disputa permanente.

En Colombia y específicamente en Bogotá, diferente a la idea de encontrar una ciudad diversa y múltiple dada la riqueza social que existe como consecuencia de los múltiples proceso migratorios en el país, hoy se evidencia la materialización de un sistema social, económico y político único y hegemónico. La ciudad se ha establecido desde la invisibilización de sus formas sociales subversivas al sistema social dominante.

No obstante hoy emergen, en contraposición a esta realidad, múltiples formas de resistencias desde lo individual hasta movimientos sociales que buscan transformar la idea de una única forma de habitar la ciudad. Desde múltiples medios y desde diversos sujetos se ha buscado la reivindicación del derecho a la ciudad, el derecho de construir y habitar el espacio conforme a los deseos de sus habitantes. Es así como esta investigación se consolida desde un marco orientado teóricamente por David Harvey, Henry Lefebvre; 
Hannah Arendt; Pierre Bourdieu y desarrollada desde una metodología cualitativa, la cual es guiada desde los aportes de la comunidad indígena Nasa, quienes buscan nutrir la discusión sobre la realidad de lo indígena en la ciudad.

\section{Palabras clave}

Ciudad; indígenas nasa; desplazamiento; prácticas; identidad.

\section{Introducción}

El contexto en Colombia se ha cimentado desde la consolidación de realidades guiadas en gran medida por amplios procesos de desplazamiento interno en el país. Grandes oleadas de masas migratorias de lo rural hacia lo urbano y viceversa han modificado, diversificado y transformado las formas de habitar de los habitantes en los diferentes territorios del país.

La ciudad por su parte se constituye como el lugar con mayor recepción de población en el país, mayoritariamente proveniente de áreas rurales. Dado el encuentro de múltiples culturas en el espacio, el contexto supondría el enriquecimiento en tanto diversidad cultural en la ciudad. No obstante, una vez confrontada la realidad, es posible visibilizar la ausencia de lo múltiple, de la pluralidad de formas de ser, pensar y actuar.

Para el caso de las comunidades indígenas que se han desplazado, se evidencian serias afectaciones en las diferentes esferas de la vida cotidiana: la economía, los lazos familiares y comunales, la cultura misma, entre otros aspectos de la vida resultan transgredidos, dada la influencia del sistema económico, social, cultural, jurídico que impera como único sistema legítimo en la ciudad. 
Además, para el caso de las comunidades indígenas, se han constituido imaginarios sociales que responden a modelos identitarios esencialistas. Es decir, identidades asignadas que reconocen la idea de la vida indígena en un contexto único rural: aislado, ancestral, agrícola, etc. Ahora bien, en el terreno práctico tales afirmaciones se llenan de contradicciones y cuestionamientos una vez las comunidades son desplazadas de sus territorios para habitar la ciudad. Emergen así cuestionamientos tales como: ¿es posible la continuación de la cultura indígena en un contexto de ciudad?; una vez sumergidos en lógicas económicas, sociales distintas, ¿cómo sobrevive lo indígena?; ¿qué formas de resistencias pueden presentar las comunidades indígenas en la ciudad?; entre otros tantos interrogantes.

Para el caso específico de las comunidades indígenas que habitan en el departamento del Cauca y de acuerdo con fuentes institucionales, el 12,2\% de esta población, es decir 30.357 indígenas han sufrido la expulsión de sus territorios por procesos violentos (RUV, 2016).

Tal situación representa la crisis de desplazamientos presente en el país desde la mirada particular de un departamento colombiano, y desde la perspectiva específica de las comunidades indígenas, realidad que constituye un problema de investigación contemporáneo necesario de reflexión.

En la búsqueda de dar voz a las comunidades indígenas sobre estos cuestionamientos y debatir alrededor de esta problemática, nace la investigación "Prácticas e identidades indígenas en contexto de ciudad: el caso de la comunidad indígena Nasa del Cauca, en Bogotá, Colombia" (Roncancio, 2017), trabajo finalizado y razón última del presente artículo, el cual tiene el objeto de visibilizar aquellas reflexiones que emergen en el recorrido de este ejercicio investigativo.

Como objetivo general de la investigación, se propuso analizar las implicaciones del proceso de desplazamiento de Cauca hacia la ciudad de Bogotá, en las prácticas e identidades de la comunidad indígena Nasa adscrita al cabildo Nasa de Bogotá para el año 2017. Y como objetivos 
específicos, se establecieron los siguientes: 1) determinar las características sociodemográficas de la comunidad indígena y especialmente del pueblo Nasa en Bogotá; 2) conocer el contexto que favoreció el desplazamiento de la comunidad indígena Nasa hacia la ciudad de Bogotá; 3) analizar las transformaciones en las prácticas indígenas del pueblo Nasa perteneciente al Cabildo Nasa en Bogotá; 4) conocer cómo se configura la identidad en la comunidad indígena Nasa en contexto de ciudad.

\section{Marco teórico/marco conceptual}

En este orden, para comprender cuáles son las transformaciones en las prácticas e identidades de las comunidades indígenas en contexto de ciudad, se establecieron categorías teóricas que orientan conceptualmente y desde una perspectiva general la realidad que transversaliza la vida de la comunidad indígena Nasa en Bogotá. Se definieron así, las categorías analíticas: desplazamiento, prácticas indígenas, identidad y ciudad.

Para comprender la categoría analítica de desplazamiento, se hace uso de los análisis realizados por Hannah Arent (1998) sobre los "apatridas" y las posteriores interpretaciones de Uribe de Hincapié (2000) sobre estos tratados conforme al contexto colombiano, además de los aportes de Lozano (2005) sobre el desarraigo.

Prácticas indígenas nace como categoría de análisis de acuerdo al constructo teórico de Pierre Bourdieu sobre la teoría de la acción y el sentido práctico. Bajo estos postulados es posible entender los diferentes elementos que condicionan la vida de los migrantes indígenas y que permiten o no la transformación de las formas de habitar en la ciudad.

Así mismo, la categoría identidad se construye en este marco analítico con base a las reflexiones guiadas desde el autor Zygmunt Bauman (2005). Finalmente la categoría 
de ciudad se establece con base a las reflexiones teóricas de Limonad \& Monte-Mór (2012), Medina (1998) y Harvey (2013).

\section{Metodología}

Esta investigación fue llevada a cabo a partir desde una postura epistemológica comprensiva e interpretativa. El enfoque investigativo es cualitativo y el tipo de estudio fue descriptivo e interpretativo. Las técnicas de investigación empleadas fueron el análisis de contenido (fuentes primarias y secundarias), entrevista semiestructurada, observación participante, observación no participante y los diarios de campo.

El análisis de datos fue desarrollado fundamentalmente bajo la síntesis de la información recolectada en los diferentes espacios visitados en una matriz analítica, además de la transcripción completa de las entrevistas. Finalmente toda la información recolectada es codificada y analizada desde el software Atlas ti.

\section{Análisis y discusión de datos}

En primer lugar cabe resaltar que el desplazamiento es entendido desde esta perspectiva investigativa como un concepto general referido al movimiento de los cuerpos por razones o bien voluntarias, o bien, forzadas.

En este sentido, el desplazamiento se divide en dos subcategorías analíticas: migración y desarraigo. Para el primer caso, da cuenta del proceso de desplazamiento que es producto de una decisión personal y no forzada; en otras palabras, es aquella persona que se desplaza voluntariamente con el fin de encontrar mejores condiciones sociales, culturales y/o económicas (ACNUR, 2015). La segunda 
subcategoría, el desarraigo, comprende aquel caso de desplazamiento interno o externo en un país, que implica la movilidad en el territorio, o bien de las prácticas culturales propias de una comunidad, por razones ajenas a la voluntad (Lozano, 2005).

En cuanto a la primera subcategoría de desplazamiento -la migración-, fue posible evidenciar desde el trabajo de campo realizado, como la comunidad indígena se moviliza con intereses individuales, los cuales emergen desde la voluntad y deseos propios.

Fundamentalmente la toma de esta decisión tiene que ver con aquellas conexiones familiares que se encuentran establecidas en la ciudad y se consolidan como un contacto de llegada, de recepción para quien se desplaza. Tal lazo de familiaridad o amistad permite una percepción de seguridad y tranquilidad la cual impulsa a la comunidad a desplazarse sin someterse a altos riesgos e incertidumbre sobre el lugar de vivienda, trabajo, educación, hasta afectaciones a nivel emocional con sentimientos como la soledad y frustración.

Ahora bien, siendo Colombia el segundo país con mayores índices de población desplazada en el mundo, se profundiza con mayor detenimiento la significación del desarraigo en este estudio. Desde la categoría principal de apátrida se comprenden las particularidades de tal desplazamiento forzado en el contexto del país.

La primera característica que se evidencia de la apátrida desde Arent (1998) es la "pérdida de hogar patriótico", tal situación se refiere a la pérdida del hogar inmediato en el contexto colombiano; es decir, la ruptura y quiebre en las relaciones vecinales, comunitarias y también económicas (Uribe, 2000).

Así mismo, la comunidad Nasa refirió sobre dicho quiebre en las diferentes esferas de la vida de un comunero luego de los procesos de desplazamiento forzado hacia la ciudad: a nivel cultural se viven situaciones de discriminación y segregamiento; a nivel económico el desempleo 
emerge como constante, con empleabilidad en trabajos de poca cualificación; y a nivel comunal, la fractura social es evidente. La comunidad se encuentra por tanto revictimizada en la ciudad.

Ahora bien, desde la comunidad Nasa fue posible visibilizar la existencia de un referente histórico que esta situación de vulnerabilidad, y de pérdida de territorios y ruptura de su vida social, hace parte de una realidad habitada desde la denomina invasión española en territorios ancestrales. El desplazamiento se constituye como una figura histórica y repetitiva en la vida de los indígenas, no es pues un fenómeno moderno, ni actual. Por el contrario hace parte de un atavismo aún no superado, repetido hoy bajo un mismo marco de colonización-dominación.

La segunda característica de la apátrida es la "pérdida de leyes", traducido al contexto colombiano es aquella pérdida del monopolio legítimo de leyes y mandatos por parte del Estado en la totalidad del territorio nacional. Dado el abandono institucional en zonas rurales, se constituyó el contexto perfecto para la emergencia de nuevas leyes creadas por actores armados ilegales, quienes luchan por la hegemonía del poder territorial desde medios violentos (caso de paramilitares, Bacrim, y guerrillas) y hoy son la razón de muchos desplazamientos forzados en los territorios rurales, dada la inestabilidad de un lugar seguro para habitar (Uribe, 2000).

La comunidad Nasa evidenció, en efecto, cómo la ausencia estatal en Nación, ha posibilitado la territorialización de diferentes actores armados ilegales en territorios indígenas con fines de dominación de los recursos, rutas de comercio y de la mano de obra, etc. Si bien se evidencia la presencia de guerrillas, paramilitares, además de multinacionales y demás empresas han apropiado por falta de garantías estatales para las comunidades indígenas negándose la legalidad y legitimidad de mandatos en y del territorio indígena. 
Finalmente la última característica que señala Arendt (1998) es la "pérdida de protección", tal situación es manifiesta desde la ausencia estatal en la protección efectiva de los derechos humanos. En Colombia se ha configurado el espacio rural desde la ausencia institucional, tal violencia estructural es potencia de un producto hoy visible en los territorios. El abandono estatal y transversal en la vida de las comunidades rurales: economía, salud, educación, vivienda, trabajo, derecho a la paz, es pues esta otra razón que obliga hoy a los indígenas a desplazarse hacia espacios urbanos, lugares que antagónicamente a lo rural cuentan con mayor atención y protección de los derechos humanos.

Ahora bien, la ciudad no es propiamente un lugar de derechos efectivos, muchas veces quien sufre desarraigo desde lo rural no cuenta con su condición de víctima en la ciudad, situación que incrementa aquella pérdida de protección en todo territorio de la cual habla Arendt (1998).

En conclusión el desarraigo es un proceso de larga duración que no afecta en un momento y lugar determinado, por el contrario, extiende sus consecuencias en diferentes niveles y momentos en la vida del desplazado.

... es un proceso de rupturas complejas producidas en el ser $\mathrm{y}$ el hacer de personas, grupos y comunidades con miras a su subyugación o sometimiento. Dentro de esas rupturas se inscriben tanto los cambios de lugar como las servidumbres forzadas en los mismos lugares de residencia y trabajo tradicionales; tanto los cambios forzados en las prácticas de producción e intercambio económico, como en las visiones e imaginarios del cosmos; tanto los quiebres en las organizaciones familiares y sociales, como la negación de los derechos políticos. Desarraigo es una ruptura de canales vitales de carácter material y simbólico hecho con el fin de subyugar o desaparecer una población en una dinámica de conquista, y dominación. (Lozano, 2005, p. 285) 
No obstante, desde Lozano (2005) se evidencia cómo luego del proceso de desarraigo, quienes son sobrevivientes tienen la facultad de construir nuevas formas de habitar. El desarraigo, si bien cuenta con consecuencias de larga duración en la vida personal y social de quienes la sufren, no constituye un patrón de vida permanente. Ser sobreviviente al desarraigo implica también la construcción de nuevas formas de habitar, de adaptación en el nuevo ambiente; implica dar vida a un nuevo brote de raíces en el lugar de llegada.

Tal situación de llegada representa retos de adaptación específicos para la comunidad indígena, definidos en primera instancia de acuerdo a la condición por la cual se da el desplazamiento, sea forzado o voluntario, ya que desde este primer momento se define la posición de los comuneros en el campo social de la ciudad.

Los diferentes campos sociales establecidos en la ciudad, como lo dijo Bourdieu (1997), son campos de juego y lucha social en donde se debate la hegemonía y formas de producción social en el espacio. La comunidad Nasa que inicia un proceso de vida en la ciudad, inscribe su posición en el campo de juego de acuerdo a sus prácticas, ya sean estas como productores o como reproductores. Ser productor de prácticas en ciudad sería pues construir la vida cotidiana desde los deseos propios, de acuerdo a los intereses del ser y en las diferentes esferas de la vida. Por otro lado, ser reproductor de prácticas implica un alineamiento con las prácticas sociales, culturales y económicas establecidas en la ciudad y por tanto la supresión o eliminación los deseos propios sobre el territorio. Así, toda persona que se encuentre dentro del campo de juego es un agente con la capacidad de transformar las estructuras de la ciudad, o de ser seguidor de las mismas.

En la ciudad de Bogotá, impera como legítimo un único sistema político, social y económico; esto, producto de luchas históricas donde se ha hegemonizado el poder neoliberal, la democracia representativa, etc. Para la comunidad 
indígena Nasa, jugadores adscritos dentro del campo de juego y de batalla en la ciudad, una vez son desplazados definen su posición de subordinación o dominación de acuerdo a los diferentes capitales que posean (sociales, culturales, simbólicos, económicos) ya que desde la suma de estos se desprende el habitus de los comuneros; es decir, aquel principio estructurador y estructurante que da sentido a las prácticas del jugador en los diferentes contextos.

Desde la realidad práctica, una vez que la comunidad indígena Nasa se inserta en la ciudad se visibiliza un imaginario social que gira alrededor de la pérdida y fractura de las prácticas ancestrales de la comunidad una vez se desplazan. Prácticas sociopolíticas tales como el seguimiento a las autoridades espirituales, abuelos y abuelas; la directriz política administrativa del cabildo en los diferentes resguardos; la jurisdicción especial indígena, la guardia indígena, procesos sociales desde la minga. A nivel cultural se evidencia como en el departamento del Cauca, se encuentra la presencia del médico tradicional o tehuala; la tulpa como lugar de encuentro en las familias; el idioma Nasa Yuwe y la práctica de los tejidos. Y a nivel económico, la comunidad establece que sus formas de producción son determinadas por dos formas agrícolas. La primera en pequeña escala, llamado el tul; la segunda y a nivel macro se encuentra la roza, lugar de siembra en mayor escala, entre otras formas de habitar propias de las comunidades indígenas.

Ahora bien, dichas prácticas culturales, económicas y políticas propias de lo indígena en el territorio, evidencian imaginarios sociales únicos sobre la comunidad indígena. Un "deber ser" de la comunidad, que da cuenta de la esencialización de la vida de los comuneros Nasa, dado el lugar de prácticas únicas y lugares específicos para habitar como imperativo de la vida indígena.

No obstante es importante señalar, como en los territorios indígenas no se constituyen como territorios "puros" donde las únicas prácticas vigentes son las propiamente indígenas. Tal como en cualquier lugar que ha sido habitado 
por diferentes culturas, que ha sido objeto de diferentes procesos migratorios (caso de colonización española, presencia de negritudes, presencia de campesinos, etc.), evidencia diversidad a nivel territorial y en sus habitantes. Si bien la comunidad Nasa se identifica hoy como indígenas frente a otros grupos sociales, su realidad concreta no es comparable con la realidad de lo indígena en el siglo xv.

Obviamente la globalización nos llega a todos, porque muchos de los indígenas tenemos celulares, WhatsApp, Facebook, porque es normal, en el siglo en el que estamos la globalización ya lleva de todo. Uno compra ropa, cosas así diferentes a las que utiliza en el resguardo, pero eso no implica que su pensamiento se haya cambiado, el ser indígena y el ser Nasa no está en ser como me veo físicamente, sino en cómo soy desde el corazón. (Entrevista, Comunera 9: 17 de Marzo de 2017).

Así pues, la situación del indígena en la ciudad se complejiza en una escala mayor, pues no solo sus derechos básicos no son reconocidos, situación que sucede con gran proporción de desplazados forzados en Colombia, sino que también sus derechos específicos como comunidad indígena son negados dado el referente de lo indígena que habita solo en lo rural; el lugar para habitar en la ciudad no resulta válido.

Esto tiene como punto de partida la inscripción del discurso sobre el modelo identitario "antropológico indigenista” que evidencia características únicas de lo indígena

... se asumen como esenciales: un sujeto colectivo, una lengua común, una historia compartida, una relación especial casi simbiótica con un territorio, y que permiten una diferenciación prácticamente evidente a primera vista que cumpla con estas particularidades podrá ser considerado como indígena. (Quintero \& Vargas, 2013, p. 13) 
El Estado colombiano legítimo tal perspectiva teórica y desde allí se construyó el marco jurídico que cobija los derechos de los pueblos indígenas, derechos reducidos al cumplimiento de tales cánones infranqueables.

Una vez fuera de estos límites territoriales indígenas, las comunidades quedan desprotegidas de sus derechos y legitimidad de habitar diversos espacios como los urbanos desde la garantía de sus derechos étnicos. Por tanto, en la búsqueda de lograr un análisis que profundice esta problemática, se visibiliza que aquel indígena que es obligado a vivir en la ciudad o que vive en ella por su decisión, debe luchar contra todo un constructo discursivo y estructural que sitúa a su comunidad y a sus prácticas en el espacio rural como único lugar legítimo de habitar.

Se debe pues partir de una autosocioreflexión como evidencia Bourdieu (1997) para comprender la posición en que se encuentra lo indígena en Bogotá, y enfrentar así los procesos en los campos de juego de la ciudad con los diferentes capitales que se posean. La manera en que la comunidad y cada individuo manejen sus capitales y las oportunidades que se presenten en la ciudad, es un punto de fuga a un sistema social, económico, político y cultural único, no solo visto desde la perspectiva identitaria de lo indígena, sino de las formas únicas de habitar el espacio de la ciudad.

En este marco, la presencia de las comunidades indígenas en territorios diversos como la ciudad, crea una apertura a nuevas posibilidades de visibilizar las múltiples formas de vida y lugares posibles para habitar por las comunidades indígenas desde la garantía plena de sus derechos. En la ciudad de Bogotá, la comunidad Nasa ha buscado reivindicar sus derechos étnicos, desde la apropiación de los códigos y lenguaje de la ciudad, utilizados para visibilizar la realidad indígena no solo de quienes viven en contexto de Bogotá, sino la realidad de quienes habitan en la Cauca rural y urbana. 
De esta manera, el habitus se constituye como aquellas construcciones estructurales en el ser, que tienen que ver con la historia inscrita en el cuerpo de cada sujeto, con las relaciones sociales que dan cuenta de una manera específica de comprender la realidad y por tanto actuar en consecuencia a esas reflexiones.

Enfrentarse a un contexto diferente, desencadena contradicciones frente a las prácticas aprendidas culturalmente a lo largo del tiempo, no obstante también abre posibilidades para desarrollar nuevas prácticas que reivindiquen su agencia en diversos espacios sociales y no solo en un territorio específico. (Roncancio, 2017, p. 31)

Es el caso de los procesos de territorialización de las formas organizativas indígenas en la ciudad, que pese a no ser válidas legalmente en un territorio distinto al circunscrito como territorio indígena, se hace legítimo desde la comunidad. Es visible la apropiación de espacios en la ciudad para dar lugar a reuniones con fines colectivos e intereses como organización, así se ha dado lugar al surgimiento del Cabildo Nasa de Bogotá, a la fuerza de su guardia indígena, además de la apertura a nuevos espacios como la Cátedra Nasa, clases de idioma Nasa-yuwe dictado por comuneros Nasa, clases de tejido indígena por parte de las mujeres en la ciudad; además de la visibilización de logros de las comunidades indígenas en espacios como la conmemoración del día de las lenguas Nativas; sumado a espacios artísticos como la exposición fotográfica "Raíces en cemento" y la exposición de arte "Panorama 5: subtextos y contextos entre conflictos", entre otros tantos. Tales espacios se establecen en la ciudad como lugares de encuentro de la diversidad: son espacios interculturales que permiten un diálogo y enriquecimiento de los valores culturales de la nación por parte de quienes la integran, superando así aquel sesgo cultural que trata la multiplicidad desde exacerbación de las diferencias y no desde el enriquecimiento múltiple 
... es posible tomar una mirada multicultural frente a la realidad, es decir reconocer las múltiples diferencias, pero desde una perspectiva social estática, y esencialista sobre sí, como los etnicismos radicalizados. O por el contrario situarse desde una perspectiva intercultural, que reconoce los múltiples conocimientos desde una perspectiva horizontal, de-construida en tanto discursos de poder: dominador y dominado; allí es posible un intercambio de saberes, sin la negación de la propia identidad. (Roncancio, 2017, p. 114)

Ahora bien, frente a esta situación emergen cuestionamientos sobre la identidad, finalmente cómo se construye una vez se está separado de algunas prácticas indígenas, además de la pérdida de relación con el territorio y la comunidad de nacimiento. Tal como evidencia Bauman (2005), es preciso comprender la identidad como una categoría que está en constante configuración y reconfiguración, no es pues una categoría cerrada y pura. Las diferentes circunstancias por las cuales cruza el agente, las diferentes estructuras que le son transversales, los diversos actores que transitan en el campo de juego, crea espacios de repensar el sentido de acciones, prácticas, da lugar a diversificar el pensamiento. "Las variaciones son constantes y transversales en la vida cotidiana, varían los elementos estructurantes de los campos, varían también las construcciones y las manifestaciones internas de cada agente sobre el espacio" (Roncancio, 2017, p. 35).

Desde este estudio fue posible visibilizar en primera medida la necesidad de deconstruir el imaginario sobre aquel único concepto de la identidad indígena esencializado hacia unas formas particulares de relacionarse con la sociedad. La identidad

... no representa pues una configuración única e inacabada, por el contrario, abre el espectro para la emergencia de tantas identidades como campos de lucha en definición se establezcan en la sociedad. Las identidades indígenas no se determi- 
nan entonces de acuerdo al factor étnico como determinante final, sino con las construcciones sociales que el sujeto apropia y desde las cuales se reconoce. (Roncancio, 2017, p. 114)

La actualización de esta categoría requiere dar voz a las formas educativas, organizativas, artísticas, individuales, etc., que se gestan en la actualidad y que emergen como respuesta a las necesidades que se presentan en la realidad contemporánea.

Es como que llega alguien y uno dice soy indígena y soy Nasa y todo el mundo dice "¿Cómo? ¡Ay yo pensé que todavía utilizaban taparrabo! Y ¿dónde está la pluma?”, uno dice: "Estamos en pleno siglo XXI y ¿usted está pensando en eso?". (Entrevista, Comunera 8: 17 de Marzo de 2017). (Roncancio, 2017, p. 111)

Así, desde esta investigación se da lugar a un acercamiento sobre la configuración de las identidades indígenas desde dos connotaciones: la subjetiva y la colectiva, tales perspectivas hacen parte de un mismo constructo identitario analizadas desde miradas diferenciales.

En primer lugar, el aspecto subjetivo de la identidad, tiene que ver con el habitus construido individualmente, ya sea desde el territorio originario o desde la ciudad. Este da cuenta de las formas de interpretar la vida, del sentido teleológico que se imprimen a las acciones con los otros y con el entorno. Desde una perspectiva indígena, implica la consecuencia de las acciones y de los pensamientos de acuerdo a los mandatos filosóficos indígenas, la comprensión de todo como totalidad

... los comuneros tienen la responsabilidad de preservar los valores filosóficos que guían los preceptos indígenas desde una mirada individual y propia. Esto quiere decir que, en un contexto de ciudad, entendido como campo de lucha, se disputa también la legitimidad y la pervivencia de la lógica subjetiva y el fin teleológico de cada una de las acciones. (Roncancio, 2017, p. 115) 
... cada ser indígena tiene ese grado de corresponsabilidad; ellos verán si sus prácticas las dejan perder, si solo los va impulsar el tema presupuestal o realmente van hacer reflejar el tema indígena y a sentirlo. Es muy diferente yo tener unos rasgos indígenas y no reconocerme ni sentir que soy indígena, entonces yo puedo tener todos los rasgos pero si yo no siento ser indígena no estoy en nada [...] para poder sostener un poco lo que traemos de territorio, es seguir sintiendo ser indígena. (Entrevista, Comunera 7: 08 de Marzo de 2017). (Ibidem)

Tal aspecto subjetivo no implica la permanencia en el territorio indígena, mas sí las acciones guiadas por el pensamiento indígena "Usted se puede ir a la China, vivir con otra cultura, contemplar otras cosas, pero usted va seguir siendo un Nasa en la China, lo mismo cuando una migra a las urbanidades (Entrevista, Comunera 8: 17 de Marzo de 2017)” (Roncancio, 2017, p. 115).

Por otro lado, el aspecto colectivo de la identidad implica el desarrollo de acciones afirmativas que permitan la construcción de una organización indígena. Significa tener accionar de manera concreta y activa que permita la creación, desarrollo o fortalecimiento de los procesos comunitarios en los diferentes espacios donde se establezcan las comunidades indígenas.

Otra perspectiva identitaria que se establece en las comunidades, tiene que ver con los procesos de aculturamiento

la pérdida total o parcial de lo identitario como resultado del choque cultural, y de una relación social entre dominador y dominado; es materializado desde la colonialidad del ser, del saber y del poder, y hace parte de un proceso hegemónico que busca la dominación y homogenización de un poder específico en lo social. (Roncancio, 2017, p. 117)

Finalmente cada individuo actúa de acuerdo a la forma en que ha interiorizado el habitus indígena en sus prácticas de vida. Cada cual tiene la facultad de ser reproductor de 
formas hegemónicas de habitar o ser constructor de nueva maneras, democráticas, incluyentes, interculturales, en los diversos espacios en que se encuentre.

\section{Conclusiones}

Para comprender la realidad de las comunidades indígenas que habitan la ciudad, se hace necesario desacralizar el concepto ahistórico que comprende la vida indígena como una realidad inamovible luego del periodo de colonización española. La identidad indígena es un concepto enteramente complejo, nutrido de diversas raíces. Hoy consolidado como un proceso de creación, transformación, reestructuración constante.

Es preciso en consecuencia comprender que los territorios indígenas en Cauca no se construyen como espacios inscritos bajo una única cultura y forma de producción. Contrario a esto, existen diferentes territorios -tanto cuerpos como suelos- traspasados por la historia misma que ha transitado sobre ellos.

Es por esto imprescindible establecer que las comunidades indígenas no han habitado un único lugar, el rural, como arbitrariamente han sido ubicadas muchas veces por la academia, la sociedad y por el Estado. Si bien es cierto, tal discurso ha limitado no solo los espacios en los cuales los derechos indígenas son válidos, sino que a su vez ha restringido el derecho de construcción de la identidad desde la libertad de los sujetos.

Ahora bien, no se desconoce que los espacios en la ciudad se encuentran en gran medida acaparados por formas de producción capitalistas, no obstante la presencia de la comunidades indígenas representa un posible punto de fuga para crear nuevos saltos cualitativos que permitan la estructuración de espacios desde la construcción colectiva y no desde la imposición de un grupo específico de la sociedad. 
Así, o bien la presencia de lo indígena en la ciudad puede permitir la colonización de las formas de ser y/o hacer que determina el modelo económico y político imperante, o por el contrario puede constituirse como otra fuerza en búsqueda de la democratización del espacio y de las formas de producción. Habitar la ciudad desde los deseos e intenciones propios, da lugar a procesos sociales renovados en diferentes ámbitos como el jurídico, cultural, económico, social; en otras palabras, la posibilidad de habitar ciudades diversas (Harvey, 2013).

\section{Bibliografía}

Arendt, H. (1998). Los orígenes del totalitarismo. Madrid: Taurus.

Bauman, Z. (2005). Identidad. Buenos Aires: Losada.

Bourdieu, P. (1997). Razones prácticas sobre la teoría de la acción. Barcelona: Anagrama.

Harvey, D. (2013). Ciudades rebeldes: del derecho de la ciudad a la revolución urbana. Salamanca: Akal.

Lozano, F. (mayo de 2005). El desplazamiento en Colombia: regiones, ciudades y políticas públicas. Recuperado el 24 de diciembre de 2016 de https://bit.ly/2WZeSEo.

Roncancio, A. (2017). Prácticas e identidades indígenas en contexto de ciudad: el caso de la comunidad indígena Nasa de Cauca, en Bogotá, Colombia. Recuperado de https://bit.ly/2Wwl8zn.

Uribe, M. T. (diciembre de 2000). Revista Estudios Politicos. Recuperado el 11 de diciembre de 2016 de https://bit.ly/2wMO4IO. 



\section{Acerca de los autores}

\section{Sebastián Aguiar}

Doctor en Sociología por la Facultad de Ciencias Sociales de la Universidad de la República (FCS-UDELAR) (2016), magíster y licenciado en Sociología. Docente e investigador efectivo del Departamento de Sociología (DS) de la FCSUDELAR. Investigador nivel I del SNI (Sistema nacional de Investigadores). Coordinador del equipo de investigación en sociología urbana (DS-FCS-UDELAR). Autor de varios artículos, capítulos de libro y coautor y coordinador de libros en la temática. Expositor y organizador de varios congresos internacionales.

\section{Thaysa Sonale Almeida Silva}

Graduada em Geografia pela Universidade Federal de Viçosa, e mestre em Administração Pública pela Escola de Governo da Fundação João Pinheiro.

thaysasonale@gmail.com

\section{Camilo Arriagada}

Profesor asociado del departamento de urbanismo de FAU, Universidad de Chile, desde el año 2011 y antes profesor asociado del Departamento de Sociología de la misma universidad. Fue jefe de Departamento de Estudios MINVU 
de 1998 a 2008 y antes jefe de Cooperación Internacional y Asistencia Técnica, de 1992 a 2008 . Ha sido consultor de Celade, Cepal, Bid y diversos ministerios del área ciudad y desarrollo urbano. Es sociólogo por la Universidad de Chile, magíster en Desarrollo Urbano Puc, doctor en Ciencias Sociales por Flacso Argentina y posee diplomas en Economía Urbana Puc y Gerencia Pública por la Universidad de Chile.

carriagadal@uchilefau.cl

\section{Julio Calderón Cockburn}

Sociólogo PUCP (1980). Doctor, sobresaliente, por la UNMSM (2004) y maestro, con honores, por la Facultad Latinoamericana de Ciencias Sociales (FLACSO), México (1986). Profesor principal de la Universidad Nacional Mayor de San Marcos y profesor del Lincoln Institute of Land Policy (LILP) de Cambridge, Estados Unidos. Ha sido Visiting Fellow (2013-2014) del LILP y Visiting Scholarship Program del Korea Research Institute of Human Settlement de Corea del Sur (2015). Co-coordina el grupo de trabajo Ciudades del Milenio, de la Asociación Latinoamericana de Sociología (ALAS). Autor de 25 libros y 75 capítulos de libros y artículos en revistas académicas, entre ellos $\mathrm{La}$ ciudad ilegal. Lima en el siglo XX (2016) y Los pobres urbanos y la propiedad (2014). Expositor en 80 congresos internacionales en América, Europa, África y Asia.

\section{Rachel de Castro Almeida}

Arquiteta urbanista, doutora em Ciências Sociais. Atualmente, na Pontifícia Universidade Católica de Minas Gerais, é professora na graduação e pós-graduação lato sensu, assessora de ensino do Instituto de Ciências Sociais 
e pesquisadora do Núcleo de Estudos Sociopolíticos. Tem como principais interesses de pesquisa temas relacionados à juventude, inserção profissional, direito à cidade e espaço público.

rachel.castro.almeida@gmail.com

\section{Ricardo Carneiro}

Graduação em Matemática (1975), mestrado em Economia (1990) e doutorado em Ciências Humanas: Sociologia e Política pela Universidade Federal de Minas Gerais (2000). Pesquisador e professor da Escola de Governo Paulo Neves de Carvalho da Fundação João Pinheiro, atuando nos programas de graduação e pós-graduação em Administração Pública da instituição. Tem experiência nas áreas de economia do setor público, finanças públicas, administração pública e ciência política, atuando principalmente nos seguintes temas: análise organizacional e institucional, avaliação de políticas públicas, planejamento governamental, gestão urbana, gestão pública e reforma do Estado. ricardo.carne iro@ fjp.mg.gov.br

\section{Flavia Duque}

Doutora em Sociologia pela Universidade Federal de Minas Gerais (UFMG), Mestre em Sociologia também pela UFMG. Arquiteta, Especialista em Urbanismo pela UFMG. Professora da Escola de Governo da Fundação João Pinheiro, nos Programas de Mestrado, de Especialização e Graduação em Administração Pública. Tem atuado nas seguintes áreas e temas: sociologia urbana; participação social; movimentos sociais; políticas públicas e políticas urbanas; governos locais e gestão de cidades. flaviaduquebrasil@gmail.com 


\section{Ana Laura Elorza}

Doctora en Ciencias Sociales por la Universidad Nacional de Cuyo. Magíster en Gestión y Desarrollo Habitacional por la Universidad Nacional de Córdoba (UNC) y licenciada en Trabajo Social por la Escuela de Trabajo Social en la misma Universidad. Actualmente, se desempeña como investigadora asistente del CONICET y como docente de la Facultad de Ciencias Sociales, UNC. analauraelorza@gmail.com

\section{Cristhiane Falchetti}

Possui formação em Ciências Sociais (UNICAMP) e em Administração Pública (UNESP), mestrado e doutorado em Sociologia. Durante o mestrado (UNESP) pesquisou sobre o processo de institucionalização da participação nas políticas sociais considerando os impactos do processo de democratização e do neoliberalismo no Brasil. No doutorado (USP) discute conflitos urbanos envolvendo a moradia, suas políticas e agentes que atuam na produção da cidade. É autora do livro Novos arranjos e velhos dilemas na democratização das políticas sociais (editora Unesp), além de outros trabalhos na área de políticas sociais, democracia e ação coletiva. Atua como docente no ensino superior com temas da sociologia política.

c.falchetti@usp.br

\section{Nadia Finck}

Licenciada en Sociología (UBA-Argentina), magíster en Desarrollo Local (UNSAM-Argentina), doctoranda en Geografía (UBA-Argentina). Se desempeña como docente investigadora en la Universidad Nacional de Tierra del 
Fuego, Antártida e Islas del Atlántico Sur y como becaria del Concejo Nacional de Investigaciones Científicas y Técnicas.

nfinck@untdf.edu.ar

\section{Sávio Tadeu Guimarães}

Arquiteto e Urbanista, Doutor em Planejamento Urbano e Regional pelo IPPUR/UFRJ e Universidade Nova de Lisboa. No âmbito do Ensino é docente dos cursos de graduação e mestrado em Arquitetura e Urbanismo do Centro Universitário de Brasília. No âmbito da Pesquisa concentra-se na influência das tecnologias de informação tanto em arquiteturas emergentes quanto naquelas tornadas patrimônio cultural, sendo membro dos Laboratórios situ-AÇÕES/UniCEUB e LESTE/IPPUR/UFRJ. No âmbito da Extensão tem experiência como consultor do patrimônio cultural em cidades do Estado de Minas Gerais e pelo IEPHA/MG como analista de gestão e preservação do patrimônio cultural.

savio.guimaraes.2010@gmail.com

\section{Petter Isackson Maia}

Graduado em Arquitetura e Urbanismo pela Universidade Federal do Amapá e mestre em Administração Pública pela Escola de Governo da Fundação João Pinheiro. petter.isackson@gmail.com 


\section{Mario Alberto Jurado Montelongo}

Profesor-investigador titular B en El Colegio de la Frontera Norte. Dirección regional del noreste. Dos publicaciones recientes son: Jurado, Mario Alberto; Xavier Oliveras y Rosalía Chávez (2017) "La perspectiva de género en la política de obras públicas. El caso Nuevo León” en Retos y oportunidades para la transversalidad de género. Políticas públicas en Nuevo León. Coord. Silvia López y Socorro Arzaluz. El Colegio de la Frontera Norte. Jurado, Mario Alberto y Rebeca Moreno (2018) "Expresiones del proceso de gentrificación en el centro de Monterrey" en Trayectorias, año 20, número 47, pp. 54- 76. Correo electrónico: jurado.mario@gmail.com

\section{Rogério Leandro Lima Da Silveira}

Geógrafo graduado pela Pontifícia Universidade Católica do Rio Grande do Sul, mestre e doutor em Geografia Humana pela Universidade Federal de Santa Catarina, Brasil. Pós-Doutorado em Geografia e Planeamento Regional pela Universidade Nova de Lisboa, Portugal. Pesquisador do CNPq. Professor titular e pesquisador no Programa de Pós-Graduação em Desenvolvimento Regional da UNISC, Brasil. Líder do Grupo de Pesquisa Estudos Urbanos e Regionais (CNPq). Seus temas de pesquisa são: Urbanização, Cidades Médias, Planejamento Urbano e Regional, Desenvolvimento Regional. Policentrismo, Rede Urbana e Coesão Territorial. rlls@unisc.br 


\section{Aline Marcondes Miglioli}

Licenciada en Ciencias Económicas por la Universidad Estadual de Campinas (2013) y MA en Economía de la Universidad Estadual Paulista Julio de Mesquita Filho (2016). Actualmente, es aluna de doctorado en Desarrollo Económico en el Instituto de Economía de la Universidad Estadual de Campinas con la tesis "El rol de la vivienda en el modelo de transición del socialismo cubano". Tiene experiencia en el área de Sociología, con énfasis en Ciencias Económicas. Actúa principalmente en los siguientes temas: mercado inmobiliario, desarrollo económico, vivienda de interés social, política de vivienda, Cuba.

alinemmiglioli@gmail.com

\section{Rebeca Moreno Zúñiga}

Doctora en Sociología, desde 2017 se desempeña como profesora-investigadora en el Instituto de Investigaciones Sociales de la Universidad Autónoma de Nuevo León. Es miembro del Sistema Nacional de Investigadores. Sus líneas de investigación son migración indígena urbana, el espacio urbano y la gentrificación. Sus publicaciones más recientes son: La invención de la ciudad del conocimiento. Monterrey en la antesala de la violencia social, publicado en 2016; en 2016, coordinó junto a Félix E. López Ruiz el libro Praxis politica. Pensamientos y acciones para la libertad. rebekamoreno@yahoo.com

\section{Patrícia Pereira}

Doutorada em Sociologia pela Universidade Nova de Lisboa (2013), investigadora contratada da Universidade Nova de Lisboa, Faculdade de Ciências Sociais e Humanas 
(NOVA FCSH), Centro Interdisciplinar de Ciências Sociais (CICS.NOVA). Os seus principais temas de pesquisa, no domínio da Sociologia Urbana, são: vida quotidiana em contexto urbano; espaços públicos; e gentrificação, displacement e resistência.

patricia.pereira@fcsh.unl.pt

\section{Rodolfo Pinhón Bechtlufft}

Graduado em Ciênias Econômicas pela Universidade Federal de Minas Gerais. Atualmente é aluno de graduação em Administração Pública pela Escola de Governo da Fundação João Pinheiro.

rbechtlufft@msn.com

\section{Astrid Lorena Roncancio Alfaro}

Socióloga egresada de la Universidad Santo Tomás de Bogotá, Colombia.

asloroal13@gmail.com

\section{Tiago Vieira Rodrigues Dumont}

Graduado (2010) y Máster en ciencias sociales (2015), en este momento (2019) y, estudiante de doctorado, en ciencias sociales, en la Universidad Estatal Paulista "Júlio de Mesquita Filho" (UNESP), Facultad de filosofía y Ciencias (FFC), Câmpus de Marília. Realizó estudios sobre el tema latinoamericano, más concretamente, sobre el tema de la urbanización y los movimientos sociales, en países como Brasil y México; en la implementación del programa $\mathrm{Mi}$ Casa, Mi Vida, en Brasil y en el municipio de Marília-SP. 
Actualmente, investiga el impacto en las clases subalterno de políticas públicas y del proyecto nacional/Desarrollista implementado en Brasil durante el Gobierno del partido de los trabajadores (PT). Es un profesor eficaz (2012), del Departamento de educación del estado de São Paulo, donde enseña disciplina de Sociología.

tiagodumont@gmail.com

\section{Stephan Treuke}

Doctor en Ciencias Sociales por la Universidad Federal da Bahia, Salvador da Bahia, Brasil. Maestría en Filologia Románica y Geografia por la Universidad Justus-Liebig, Giessen - Alemania.

stephantreuke@hotmail.de

\section{Valentín Trinidad Dos Santos}

Licenciado en Trabajo Social por el Departamento de Trabajo Social de la Facultad de Ciencias Sociales de la Universidad de la República de Uruguay (DTS-FCS-UdelaR). Docente e investigador del Departamento de Trabajo Social (FCS-UdelaR). Integrante del Área de Hábitat y Territorio (DTS-FCS-UdelaR). Especializado en Historia Económica y Social por la Unidad Multidisciplinaria (FCS-UdelaR). Maestrando en Hábitat y Vivienda por la Facultad de Arquitectura, Diseño y Urbanismo (FADU-UdelaR). Cursando Diploma de Especialización en Estudios Urbanos e Intervenciones Territoriales del Departamento de Trabajo Social (FCS-UdelaR). Se desempeña profesionalmente en la Agencia Nacional de Vivienda de Uruguay. valentin.trinidad@cienciassociales.edu.uy 


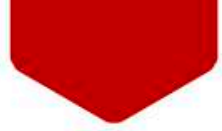

La segregación social y espacial es un tema clásico de la sociología urbana y el urbanismo, además de que progresivamente lo viene siendo de otras disciplinas. Se trata de un concepto polisémico definido a partir de la concentración de un subgrupo de población que comparte una misma característica (raza, etnia, nivel de pobreza, religión, etc.), o cuando existe una baja mezcla de hogares con condiciones disímiles. Por el contrario, no hay segregación cuando existe mezcla de hogares heterogéneos.

Esta obra presenta análisis y propuestas teóricas diversas, investigaciones de varios países de América Latina vinculados a la segregación social y espacial, a las políticas de vivienda y a los movimientos sociales. El tema de la segregación es abordado en su conexión con otras temáticas como las políticas públicas, los nuevos productos inmobiliarios, los mercados de suelo y vivienda, la ciudad informal, los movimientos sociales y las resistencias.

Los libros de esta colección siguen la lógica temática de los Grupos de Trabajo del XXXI Congreso de la Asociación Latinoamericana de Sociología (ALAS), realizado en Montevideo del 3 al 8 de diciembre de 2017, y evidencian la madurez y riqueza de la producción sociológica latinoamericana que está sustentada en su diversidad de enfoques y en su espíritu crítico. Cada texto se ubica en los debates de la actualidad social, política y cultural de la región, buscando analizarla, explicarla y confrontarla. Una sociología crítica pertinente, que se sustenta en la rigurosidad metodológica con base empírica y teórica. De esta forma, realizan una contribución destacada al desarrollo científico del conocimiento sin perder el compromiso social.

Ana Rivoir

Presidenta de ALAS Coordinadora general de la colección

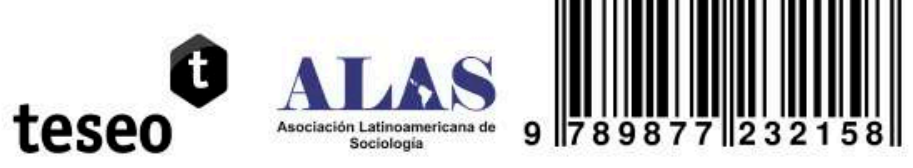

